National Water Availability and Use Pilot Program

\title{
Estimated Withdrawals and Other Elements of Water Use in the Great Lakes Basin of the United States in 2005
}

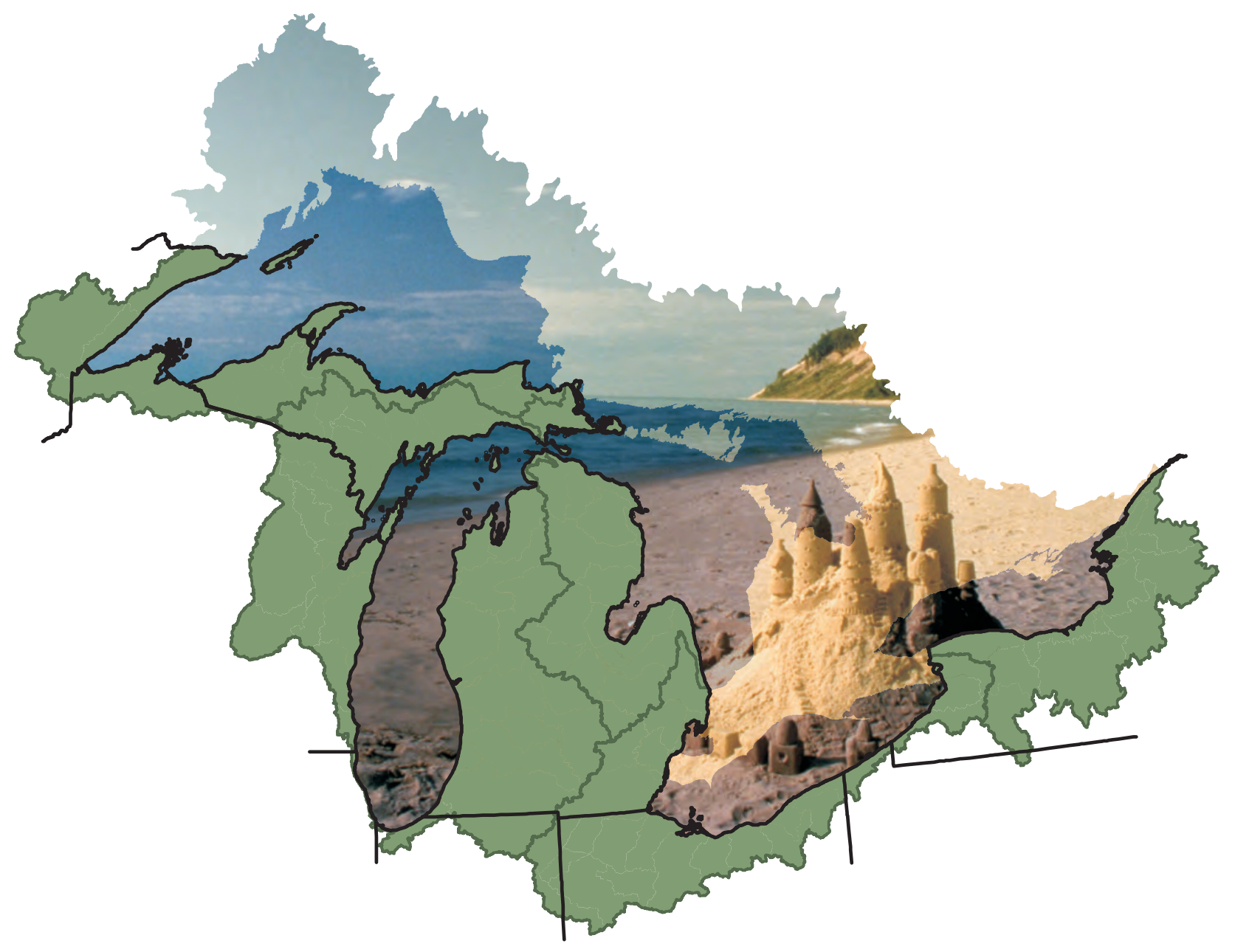

Scientific Investigations Report 2010-5031 



\section{Estimated Withdrawals and Other Elements of Water Use in the Great Lakes Basin of the United States in 2005}

By Patrick C. Mills and Jennifer B. Sharpe

National Water Availability and Use Pilot Program

Scientific Investigations Report 2010-5031 


\section{U.S. Department of the Interior \\ KEN SALAZAR, Secretary \\ U.S. Geological Survey \\ Marcia K. McNutt, Director}

\section{U.S. Geological Survey, Reston, Virginia: 2010}

For more information on the USGS - the Federal source for science about the Earth, its natural and living resources, natural hazards, and the environment, visit http://www.usgs.gov or call 1-888-ASK-USGS

For an overview of USGS information products, including maps, imagery, and publications, visit http://www.usgs.gov/pubprod

To order this and other USGS information products, visit http://store.usgs.gov

Any use of trade, product, or firm names is for descriptive purposes only and does not imply endorsement by the U.S. Government.

Although this report is in the public domain, permission must be secured from the individual copyright owners to reproduce any copyrighted materials contained within this report.

Suggested citation:

Mills, P.C., and Sharpe, J.B., 2010, Estimated withdrawals and other elements of water use in the Great Lakes Basin of the United States in 2005: U.S. Geological Survey Scientific Investigations Report 2010-5031, 95 p.

ISBN 978-1-4113-2779-5

Front-cover image: Sand castle on Lake Michigan beach, Frankfort, Michigan courtesy of U.S. Environmental Protection Agency (USEPA), Great Lakes National Program Office (GLNPO), image collection at http://epa.gov/g/npo/ image/, and Michigan Travel Bureau. Figure 6 images: Thermoelectric Power, Industrial, and Mining courtesy of USEPA, GLNPO; Industria/ photograph by Carole Y. Swinehart, Michigan Sea Grant Extension; Public Supply, "The Carter Harrison crib, shot from the Dever crib circa 1990, Lake Michigan, off Chicago," courtesy of Wikipedia.org at http://en.wikipedia.org/wiki/File:Carter-harrison-crib-from_deaver.jpg, photograph by Richard C. Drew; Aquaculture courtesy of U.S. Fish and Wildlife Service, photograph by Robert Pos; Irrigation, Domestic, and Livestock photographs by Patrick Mills, U.S. Geological Survey. 


\section{Acknowledgments}

The authors gratefully acknowledge the USGS water-use specialists in each of the Great Lakes States who compiled the data for this report and the many state, local, and Federal agencies and nongovernment entities that shared data and expertise with the USGS. In many states, personnel from cooperating agencies worked as full partners with the USGS in this compilation effort. Cooperators include state agencies that manage water resources, operate data-collection programs, and administer regulations on water use and natural resources.

The USGS water-use points of contact for each state are identified on the USGS National Water-Use Information Program Web site (http://water.usgs.gov/watuse/). Additional thanks are extended to Kristin Linsey, USGS, New York Water Science Center, and Kimberly Shaffer, USGS Ohio Water Science Center, for their efforts in verifying the data and tables. Donald

Arvin, USGS Indiana Water Science Center, and Marilee Horn, USGS New Hampshire Water Science Center, are recognized for their comprehensive technical reviews of the report. 



\section{Contents}

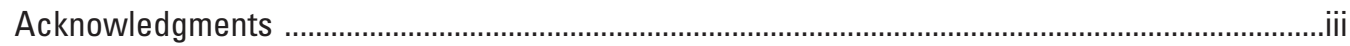

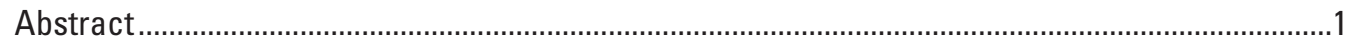

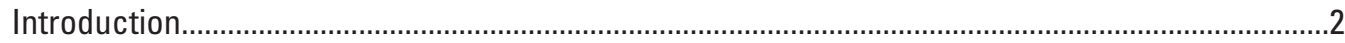

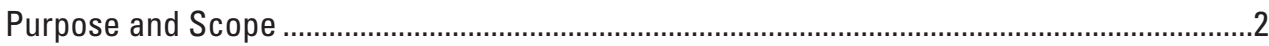

Sources of Data and Estimates .............................................................................................

Terminology Used and Changes for the 2005 National Report.................................................9

Climate and Weather.................................................................................................................. 11

Withdrawals and Other Elements of Water Use......................................................................11

Total Withdrawals and Source of Water..............................................................................12

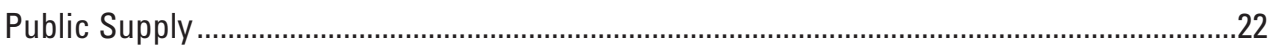

Self-Supplied Domestic ..................................................................................................................23

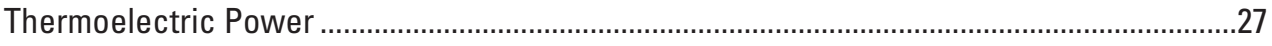

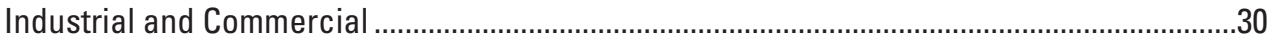

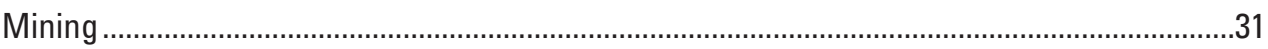

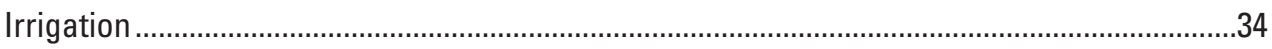

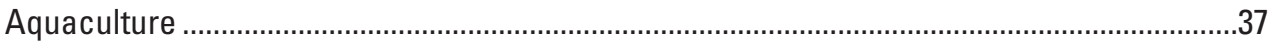

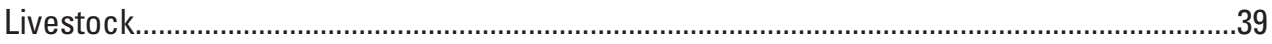

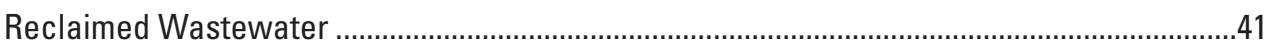

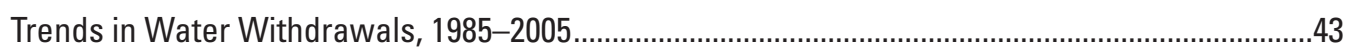

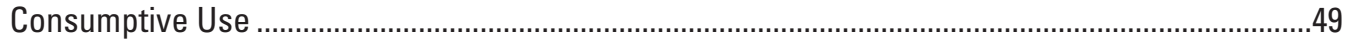

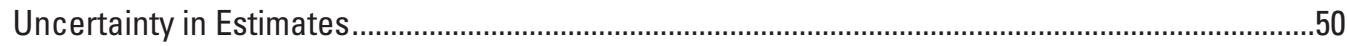

Public Supply and Self-Supplied Domestic ............................................................................55

Thermoelectric Power, Industrial, and Mining .......................................................................56

Irrigation, Aquaculture, and Livestock ..............................................................................58

Comparison with Great Lakes Commission Estimates .............................................................59

Data-Quality Summary and Suggested Improvements for Estimations of Use.......................62

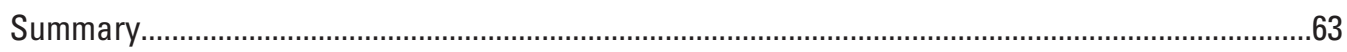

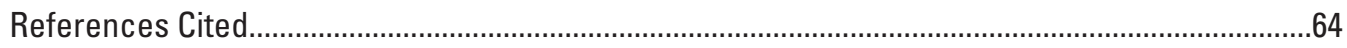

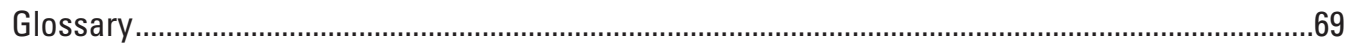

Appendix 1. Estimates of Withdrawals and Other Elements of Water Use by 8-Digit Hydrologic (Cataloging) Unit Codes (HUC) in the Great Lakes Basin, 2005

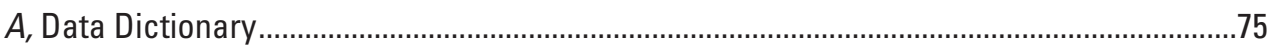

$B$, Estimates of Withdrawals and Other Elements of Water Use by State ...............................78

$C$, Estimates of Withdrawals and Other Elements of Water Use by Watershed (8-digit HUC) 


\section{Figures}

1-5. Maps showing:

1. The Great Lakes Basin and part of the upper St. Lawrence River Basin...................3

2. Distribution of population in the Great Lakes Basin, 2005.

A, Population, by watershed ........................................................................................ 4

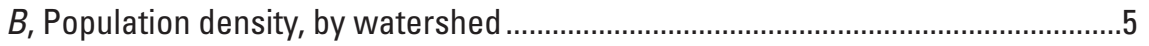

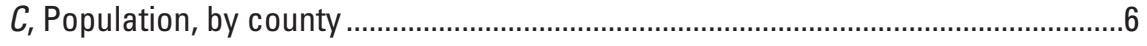

3. Land cover in the Great Lakes Basin......................................................................

4. Watersheds of the Great Lakes Basin designated by 8-digit hydrologic (cataloging) unit code (HUC) .......................................................................................

5. Total, surface-water, and groundwater withdrawals in the Great Lakes Basin, 2005.

6. Photos and graph showing total withdrawals by water-use category in the Great Lakes Basin, 2005.

7. Maps showing intensity of water withdrawals in the Great Lakes Basin, 2005.

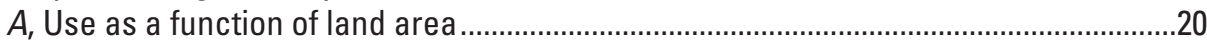

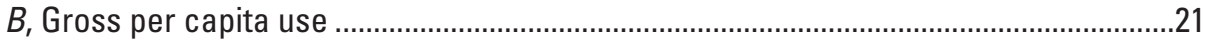

8-15. Maps and graphs showing:

8. Public-supply withdrawals by source, watershed, and state in the Great Lakes Basin, 2005.

9. Self-supplied domestic population and public-supply deliveries by watershed and total self-supplied domestic withdrawals by source, watershed, and state in the Great Lakes Basin, 2005.

10. Thermoelectric-power withdrawals by source, watershed, and state in the Great Lakes Basin, 2005.

11. Industrial withdrawals by source, watershed, and state in the Great Lakes Basin, 2005.

12. Mining withdrawals by source, watershed, and state in the Great Lakes Basin, 2005.

13. Irrigation withdrawals by source, watershed, and state in the Great Lakes Basin, 2005.

14. Aquaculture withdrawals by source, watershed, and state in the Great Lakes Basin, 2005.

15. Livestock withdrawals by source, watershed, and state in the Great Lakes Basin, 2005.

16-17. Graphs showing:

16. Trends in population and withdrawals by source in the Great Lakes Basin, 1985-2005

17. Trends in withdrawals by water-use category in the Great Lakes Basin, 1985-2005 


\section{Tables}

1. Total water withdrawals by source for Great Lakes watersheds and states in the Great Lakes Basin, 2005.

2. Total water withdrawals by water-use category for Great Lakes watersheds and states in the Great Lakes Basin, 2005

3. Surface-water withdrawals by water-use category for Great Lakes watersheds and states in the Great Lakes Basin, 2005.

4. Groundwater withdrawals by water-use category for Great Lakes watersheds and states in the Great Lakes Basin, 2005.

5. Public-supply withdrawals for Great Lakes watersheds and states in the Great Lakes Basin, 2005.

6. Self-supplied domestic withdrawals for Great Lakes watersheds and states in the Great Lakes Basin, 2005.

7. Thermoelectric-power withdrawals for Great Lakes watersheds and states in the Great Lakes Basin, 2005

8. Industrial withdrawals for Great Lakes watersheds and states in the Great Lakes Basin, 2005.

9. Mining water withdrawals for Great Lakes watersheds and states in the Great Lakes Basin, 2005.

10. Irrigation withdrawals for Great Lakes watersheds and states in the Great Lakes Basin, 2005.

11. Aquaculture withdrawals for Great Lakes watersheds and states in the Great Lakes Basin, 2005.

12. Livestock withdrawals for Great Lakes watersheds and states in the Great Lakes Basin, 2005.

13. Reclaimed wastewater use for Great Lakes watersheds and states in the Great Lakes Basin, 2005.

14. Trends in withdrawals by

$A$, Category of water use and source in the Great Lakes Basin, 1985-2005

$B$, Great Lakes watershed and state in the Great Lakes Basin, 1985-2005

15. Water withdrawals and consumptive use in the Great Lakes Basin, 2005

16. Source of water-use data and estimates by category of use for states in the Great Lakes Basin, 2005.

17. Comparison of

A, Surface-water-withdrawal estimates by the U.S. Geological Survey, 2005, and Great Lakes Commission, 2004, for the Great Lakes Basin .60 $B$, Groundwater-withdrawal estimates by the U.S. Geological Survey, 2005, and Great Lakes Commission, 2004, for the Great Lakes Basin 


\section{Conversion Factors and Abbreviations}

Inch/Pound to SI

\begin{tabular}{|c|c|c|}
\hline Multiply & By & To obtain \\
\hline \multicolumn{3}{|c|}{ Length } \\
\hline inch (in.) & 25.4 & millimeter $(\mathrm{mm})$ \\
\hline mile (mi) & 1.609 & kilometer (km) \\
\hline \multicolumn{3}{|c|}{ Area } \\
\hline acre & 4,047 & square meter $\left(\mathrm{m}^{2}\right)$ \\
\hline acre & .001562 & square mile $\left(\mathrm{mi}^{2}\right)$ \\
\hline acre & .4047 & hectometer $\left(\mathrm{hm}^{2}\right)$ \\
\hline square mile $\left(\mathrm{mi}^{2}\right)$ & 2.590 & square kilometer $\left(\mathrm{km}^{2}\right)$ \\
\hline \multicolumn{3}{|c|}{ Flow rate } \\
\hline billion gallons per day (Bgal/d) & 1.3815 & billion cubic meters per year $\left(\mathrm{Bm}^{3} / \mathrm{yr}\right)$ \\
\hline gallon per minute $(\mathrm{gal} / \mathrm{m})$ & .06309 & liter per second $(\mathrm{L} / \mathrm{s})$ \\
\hline gallon per day (gal/d) & .003785 & cubic meter per day $\left(\mathrm{m}^{3} / \mathrm{d}\right)$ \\
\hline million gallons per day (Mgal/d) & .003785 & million cubic meter per day $\left(\mathrm{Mm}^{3} / \mathrm{d}\right)$ \\
\hline million gallons per day (Mgal/d) & 1.3815 & million cubic meter per year $\left(\mathrm{Mm}^{3} / \mathrm{yr}\right)$ \\
\hline million gallons per day (Mgal/d) & 1.121 & thousand acre-foot per year \\
\hline thousand acre-feet per year & .8921 & million gallons per day (Mgal/d) \\
\hline thousand acre-feet per year & .003377 & million cubic meters per day $\left(\mathrm{Mm}^{3} / \mathrm{d}\right)$ \\
\hline \multicolumn{3}{|c|}{ Application rate } \\
\hline $\begin{array}{l}\text { million gallons per day per square mile } \\
\left(\mathrm{Mgal} / \mathrm{d} / \mathrm{mi}^{2}\right)\end{array}$ & 1,461 & $\begin{array}{l}\text { cubic meter per day per square kilometer } \\
\left(\mathrm{m}^{3} / \mathrm{d} / \mathrm{km}^{2}\right)\end{array}$ \\
\hline \multicolumn{3}{|c|}{ Various water relations in inch-pound units } \\
\hline 1 million gallons (Mgal) & & 3.07 acre-feet (acre-ft) \\
\hline 1 cubic foot $\left(\mathrm{ft}^{3}\right)$ & & 7.48 gallons (gal) \\
\hline 1 acre-foot (acre-ft) & & 325,851 gallons (gal) \\
\hline 1 acre-foot (acre-ft) & & 43,450 cubic feet $\left(\mathrm{ft}^{3}\right)$ \\
\hline 1 inch of rain (in.) & & $\begin{array}{l}17.4 \text { million gallons per square mile } \\
\left(\mathrm{Mgal} / \mathrm{mi}^{2}\right)\end{array}$ \\
\hline 1 inch of rain (in.) & & 27,200 gallons per acre (gal/acre) \\
\hline
\end{tabular}

Temperature in degrees Fahrenheit $\left({ }^{\circ} \mathrm{F}\right)$ may be converted to degrees Celsius $\left({ }^{\circ} \mathrm{C}\right)$ as follows: ${ }^{\circ} \mathrm{C}=\left({ }^{\circ} \mathrm{F}-32\right) / 1.8$

Concentrations of chemical constituents in water are given in milligrams per liter (mg/L). 


\title{
Additional abbreviations used in this report
}

\author{
Circular Refers to one or a group of U.S. Geological Survey reports titled "Estimated Use \\ of Water in the United States in [year]" that were published every 5 years from \\ 1950 to 2005. \\ AWUDS U.S. Geological Survey Aggregated Water-Use Data System \\ GIS Geographic Information System \\ GLC Great Lakes Commission \\ GLNPO U.S. Environmental Protection Agency, Great Lakes National Program Office \\ GLBP U.S. Geological Survey Great Lakes Basin Pilot \\ HUC Hydrologic unit code \\ NWUIP U.S. Geological Survey National Water-Use Information Program \\ QA Quality assurance \\ SDWIS U.S. Environmental Protection Agency Safe Drinking Water Information System \\ USDA-NASS U.S. Department of Agriculture, National Agricultural Statistics Service \\ USDOE-EIA U.S. Department of Energy, Energy Information Administration \\ USEPA U.S. Environmental Protection Agency \\ USGS U.S. Geological Survey
}





\title{
Estimated Withdrawals and Other Elements of Water Use in the Great Lakes Basin of the United States in 2005
}

\author{
By Patrick C. Mills and Jennifer B. Sharpe
}

\section{Abstract}

Estimates of water withdrawals in the United States part of the Great Lakes Basin and 107 of its watersheds designated by the 8-digit hydrologic unit code (HUCs) indicate that about 30.3 billion gallons per day (Bgal/d) were withdrawn for practically all categories of use in 2005 . Virtually all water withdrawn was freshwater. Surface-water withdrawals totaled $28.8 \mathrm{Bgal} / \mathrm{d}$, or 95 percent of total withdrawals; about 24 $\mathrm{Bgal} / \mathrm{d}$ was withdrawn from the Great Lakes or their connecting channels. Total withdrawals, and total surface-water withdrawals, decreased 7 percent from 1995 to 2005, generally following the withdrawal trends of industrial use and that of the largest use - thermoelectric power. Groundwater withdrawals increased 3 percent from 1995 to 2005 and 33 percent during 1985-2005. The substantial increase since 1985 results primarily from increases in irrigation and self-supplied domestic withdrawals. In 2005, withdrawals for public supply, domestic, and irrigation use accounted for 81 percent of groundwater withdrawals.

About $21.9 \mathrm{Bgal} / \mathrm{d}$, or 72 percent of total withdrawals for 2005, was used for thermoelectric power. Virtually all of this water was derived from surface water and used for oncethrough cooling at powerplants. As such, the reuse potential of this water in the basin is high, with the majority of the withdrawn water returned to its surface-water source.

Public-supply withdrawals were $3.81 \mathrm{Bgal} / \mathrm{d}$ (13 percent), with withdrawals declining by about 13 percent from 1995 to 2005. In 2005, about 77 percent of the population in the Great Lakes Basin obtained drinking water from public suppliers, compared to about 78 percent in 1995 and 83 percent in 1985. Surface water consistently provided about 88 percent of the total withdrawals for public supply since 1985.

Self-supplied industrial withdrawals in 2005 totaled $2.93 \mathrm{Bgal} / \mathrm{d}$ (10 percent), possibly as much as 30 percent less than in 1995. Surface water was the source for 95 percent of industrial withdrawals. Combined withdrawals for mining, irrigation, domestic, aquaculture, and livestock use (in order of decreasing rate) were $1.63 \mathrm{Bgal} / \mathrm{d}$, or only 5 percent of total withdrawals; the withdrawals were distributed almost equally between surface-water and groundwater sources. Withdrawals for each of these uses, except livestock, increased almost continuously during 1985-2005. Withdrawals for mining increased 103 percent and for irrigation 94 percent during 1985-2005; livestock withdrawals decreased 25 percent from their peak in 1990. The number of irrigated acres increased 56 percent since 1985 , totaling 750,000 acres in 2005 . No use of reclaimed wastewater for industrial or irrigation applications was reported; however, sources of information regarding its use were sparse.

Within the basin, the Lake Michigan watershed accounted for $15.0 \mathrm{Bgal} / \mathrm{d}$, or 49 percent, of total water withdrawals for 2005; an estimated $12.3 \mathrm{Bgal} / \mathrm{d}$ was withdrawn directly from Lake Michigan. The State of Michigan accounted for 38 percent of total water withdrawals, representing the largest surface-water withdrawals (primarily for thermoelectric power use) and groundwater withdrawals (primarily for public supply and self-supplied domestic use). A disproportionately large percentage of surface-water withdrawals (6 percent, $1.80 \mathrm{Bgal} / \mathrm{d}$ ) were in Illinois, given this state represents less than 1 percent of the land area of the basin. Ninety percent of the Illinois population served by the water withdrawn from Lake Michigan for public supply resides outside the basin. Within land-based HUCs, the Lower Maumee (04100009) of Ohio accounted for the largest total withdrawal and total surface-water withdrawal (about $0.75 \mathrm{Bgal} / \mathrm{d}$ ). The St. Joseph (04050001) of Michigan and Indiana accounted for the largest total groundwater withdrawal $(0.25 \mathrm{Bgal} / \mathrm{d})$.

The degree of uncertainty associated with estimates of water withdrawal varies by state and by category of use. Site-specific withdrawal data generally are available for those categories of use accounting for the largest quantities of water withdrawals: thermoelectric power, public supply, and industrial. Often these reported data are based on direct or indirect metered accounting. Estimates for domestic and livestock withdrawals typically are derived at the county level by use of coefficients and other data and then reapportioned at the HUC level on the basis of the percentage of the land area of the watershed within a county. The least uncertainty is considered associated with estimates of withdrawal for thermoelectric power and public supply; the greatest uncertainty with selfsupplied domestic withdrawal estimates. 


\section{Introduction}

At the request of Congress, the U.S. Geological Survey (USGS) is assessing the availability and use of the Nation's water resources to gain a clearer understanding of the status of our water resources and the trends in land use, water $\mathbf{u s e}^{1}$, and climate that affect them. This assessment, under the direction of the USGS National Assessment of Water Availability and Use Program (hereafter referred to as the "Water Availability Program"), is intended to improve the ability of water managers to project water availability for future economic and environmental uses (Grannemann and Reeves, 2005).

Initial efforts of the Water Availability Program, which began in 2005, were focused on determining the best methods to evaluate water resources and to develop strategies for delivering information about water availability and use. Currently (2009), the Great Lakes Basin (hereafter referred to as the "basin") (fig. 1) serves as a pilot-study area from which these strategies can be developed. A principal objective of this study is to improve the fundamental knowledge of the water balance of the basin, including the flows, storage, and water use by humans. The basin, which encompasses the drainage areas of Lakes Superior, Michigan, Huron, Erie, and Ontario and lies within eight states (Illinois, Indiana, Minnesota, Michigan, New York, Ohio, Pennsylvania, and Wisconsin) and two Canadian provinces (Ontario and Quebec), contains about 84 percent of the fresh surface water in North America and 21 percent of the fresh surface water in the world (U.S. Environmental Protection Agency, 2006a). Protecting this resource for the 34 million residents within the basin (Great Lakes Information Network, 2008), including 23 million in the United States (fig. 2), and ensuring its future availability for the many competing users is the goal of various international efforts (Council of Great Lakes Governors, 2001), as well as Federal, state, and provincial efforts. The diversity of competing uses is evidenced, in part, in the varied land cover (land use) (fig. 3 ) and economic activity within the basin. About 52 percent of the overall basin is forested (of the part of the basin that is in the United States, 53 percent is forested), 35 percent is in agricultural uses (33 percent of the United States part), 7 percent is urban or suburban ( 7 percent of the United States part), and 6 percent is in other uses such as conservation lands or recreational waters ( 7 percent of the United States part) (Great Lakes Commission, 2003; National Oceanic and Atmospheric Administration, 2009). The economy of the basin is driven primarily by manufacturing, including steel, paper, chemicals, and automobiles ( $\$ 308$ billion U.S. per year); tourism ( $\$ 82$ billion U.S.); and agriculture (\$48 billion U.S.) (Great Lakes Commission, 2003).

An understanding of water availability in an area, such as the Great Lakes Basin, requires information in addition to data on the amount of water in the hydrologic system. There is a need for information on how the system changes with time and

\footnotetext{
${ }^{1}$ Bolded terms (or close variants thereof) are defined in the glossary near the end of the report.
}

how the system reacts to changes in environmental conditions and land and water use. Determinations are needed regarding constraints on water use, including current offstream and instream use, and water-quality limitations also must be recognized. Among its other objectives, the USGS Great Lakes Basin Pilot (GLBP) attempts to compile and present water-use data that are needed for quantifying water availability. Products of the GLBP related to water use are assessments of consumptive use and return flows within the basin and their temporal variability (Shaffer and Runkle, 2007; Shaffer, 2009) and, as presented in this report, an accounting of present (2005) and past (1985-2005) water withdrawals and other elements of water use within the watersheds that compose the U.S. part of the basin. Other products of the GLBP include reports on various aspects of the surface-water systems (Neff and Killian, 2003; Neff and Nicholas, 2005; Wilcox and others, 2007) and groundwater systems (Coon and Sheets, 2006; Neff and others 2006; and Sheets and Simonson, 2006) of the basin, and analyses using various groundwater-flow models (Grannemann and Reeves, 2005; Arihood, 2009; and Howard Reeves (U.S. Geological Survey, written commun., 2010)).

\section{Purpose and Scope}

The primary purpose of this report is to present estimates of water withdrawals in 2005 for 107 surface-water watersheds (fig. 4, appendix 1) that compose the United States part of the Great Lakes Basin. Included are those watersheds with streams and channels directly tributary to the Great Lakes, each of the Great Lakes, and those of the St. Lawrence River Basin, extending upstream from the cities of Massena, N.Y., and Cornwall, Ontario (fig. 1). The watersheds, as designated by their 8-digit hydrologic (cataloging) unit codes (hereafter referred to as "HUCs") (Seaber and others, 1987; U.S. Geological Survey, 2007; Natural Resources Conservation Service, 2008), represent about $175,000 \mathrm{mi}^{2}$, or 60 percent of the multinational area of the Great Lakes Basin. For consistency with other Great Lakes Basin Pilot reports, this report excludes the evaluation, summary statistics, and discussion of withdrawal estimates from four north-central New York HUCs (04150304 to 04150307 ) that are partially in southern Canada and drain to the St. Lawrence River downstream from Cornwall. However, withdrawal estimates for these watersheds are included in appendix 1.

Withdrawal estimates are included for 10 water-use categories and for various associated elements of water use that are considered, in part, to be components of the cycle of water use or factors indicative of or contributing to the extent of water withdrawals and use. Also included are estimates of consumptive use. Sections of this report present estimates (principally withdrawal estimates) for the HUCs and summarize the estimates by (1) the basin, as a whole, (2) each receiving Great Lake (referred to as a Great Lakes watershed (fig. 1) in this report), and (3) each state area within the basin. Estimates of withdrawals and other elements of water 


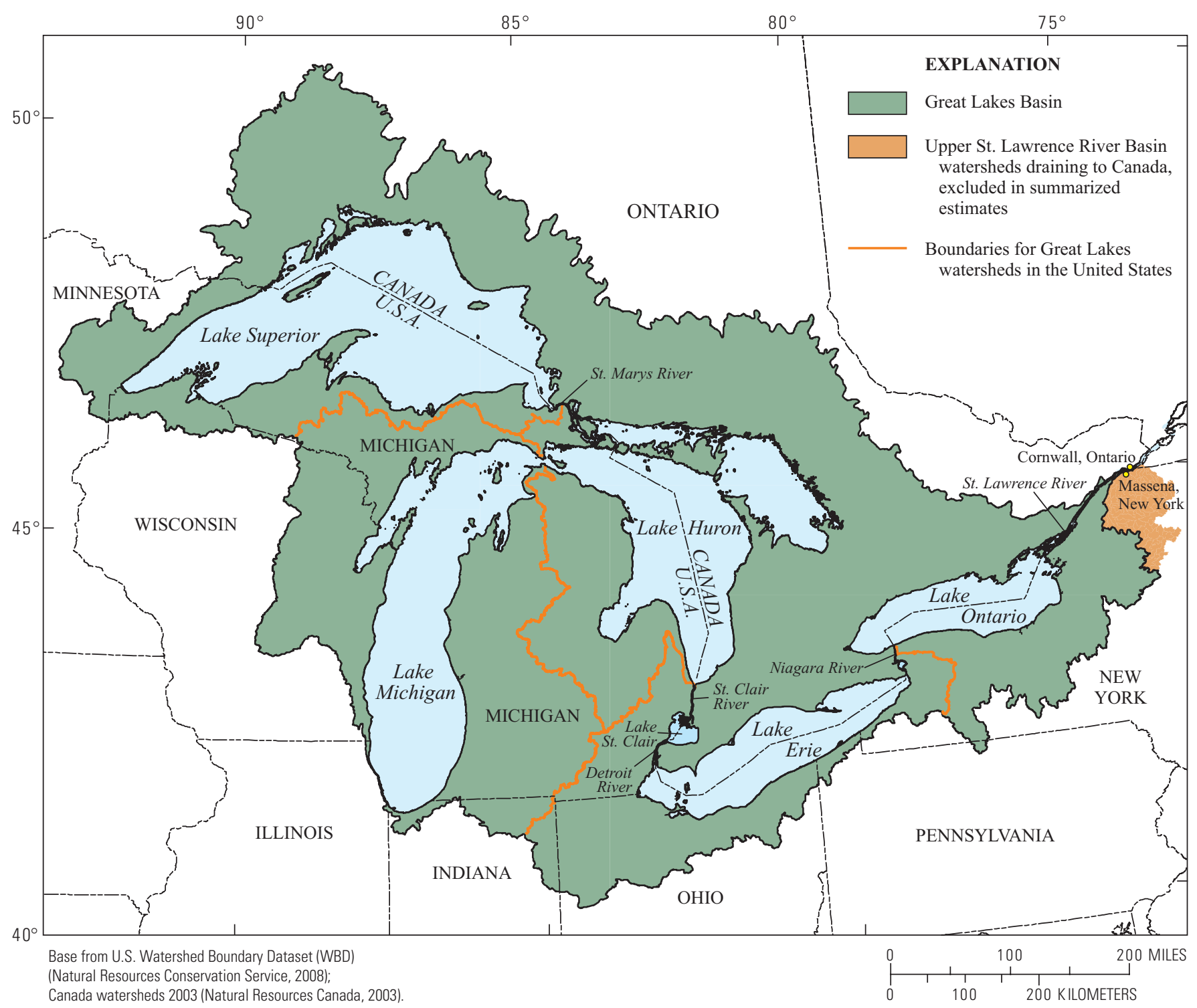

Figure 1. The Great Lakes Basin and part of the upper St. Lawrence River Basin.

use are listed by individual HUC in appendix 1; a full listing of estimates is available for download from the USGS National Water-Use Information Program (NWUIP) Web site (http://water.usgs.gov/watuse/).

Withdrawal and associated estimates are included for the water-use categories public supply; self-supplied domestic; thermoelectric power; industrial; mining; irrigation; aquaculture; livestock; and reclaimed wastewater. Also included are selected estimates for commercial use. The order of presentation of these use categories in the report is by decreasing quantities of withdrawals by category in 2005 within two groupings associated with (1) water generally associated with consumption by humans (public supply, self-supplied domestic), and (2) water generally associated with accommodating human needs other than consumption (all other uses). Also discussed in this report are trends in water withdrawals during
1985-2005, with emphasis on the period 1995-2005, and the uncertainty of withdrawal and associated water-use data and estimates by category of use and source of the estimates for each state.

The climate of the basin is described in brief to provide a hydrologic context for the withdrawal estimates that are presented. For an understanding of the physical characteristics of the basin, including the basin's hydrogeologic setting, readers are referred to the wealth of scientific and popular literature that describes these characteristics. Basic physical data regarding the basin and each of the Great Lakes are summarized by the Coordinating Committee on Great Lakes Basic Hydraulic and Hydrologic Data (1977). The geology of the basin is described in Hough (1958); the hydrogeology of the basin and vicinity is summarized in Grannemann and others (2000), the USGS Ground Water Atlas of the United States (Miller, 2000), 


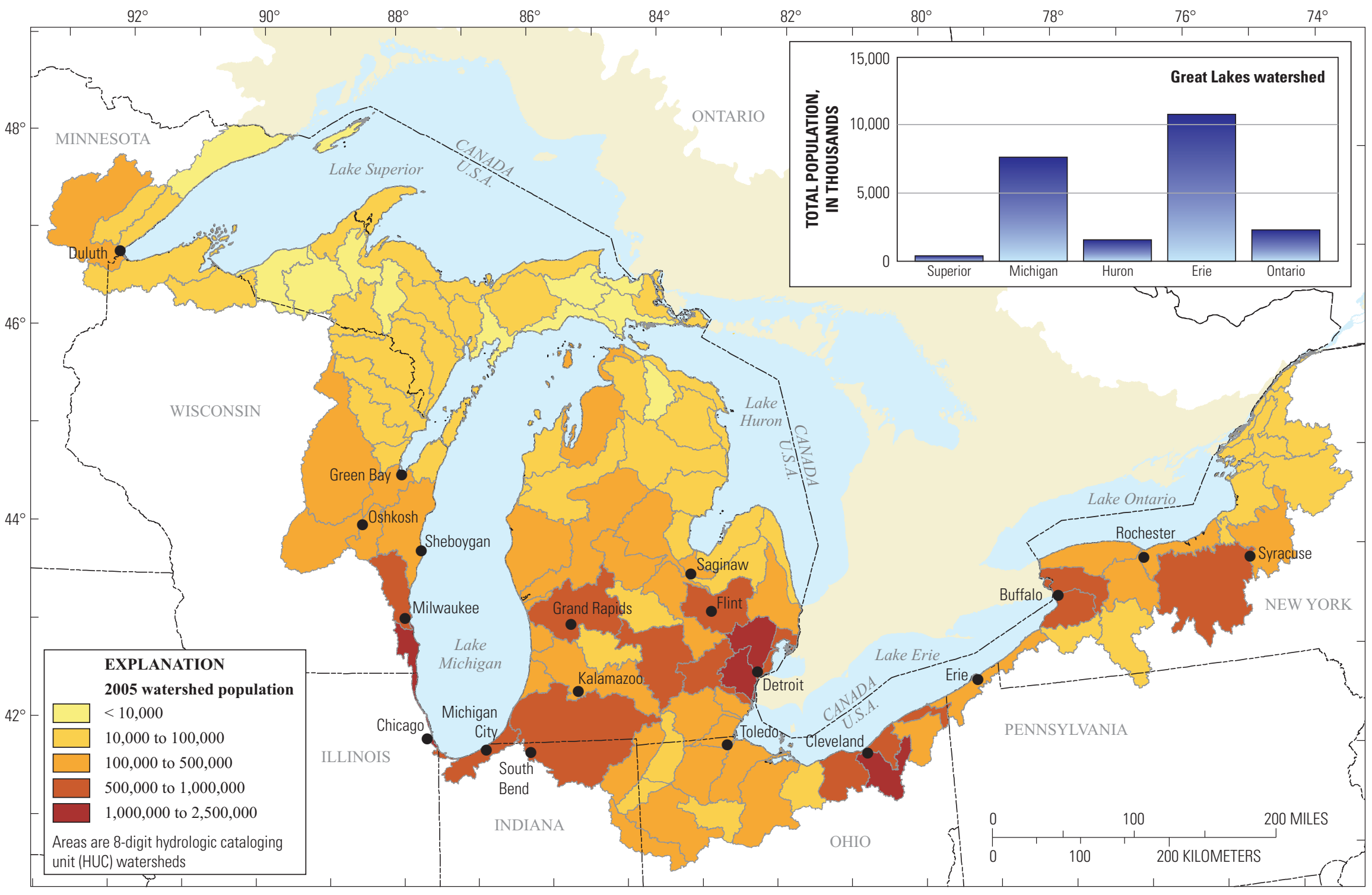

Figure 2. Distribution of population in the Great Lakes Basin, 2005. A, Population, by watershed (derived from county (2005) and block (2000) Federal census data (U.S. Department of Commerce, 2006; 2001, respectively)). 


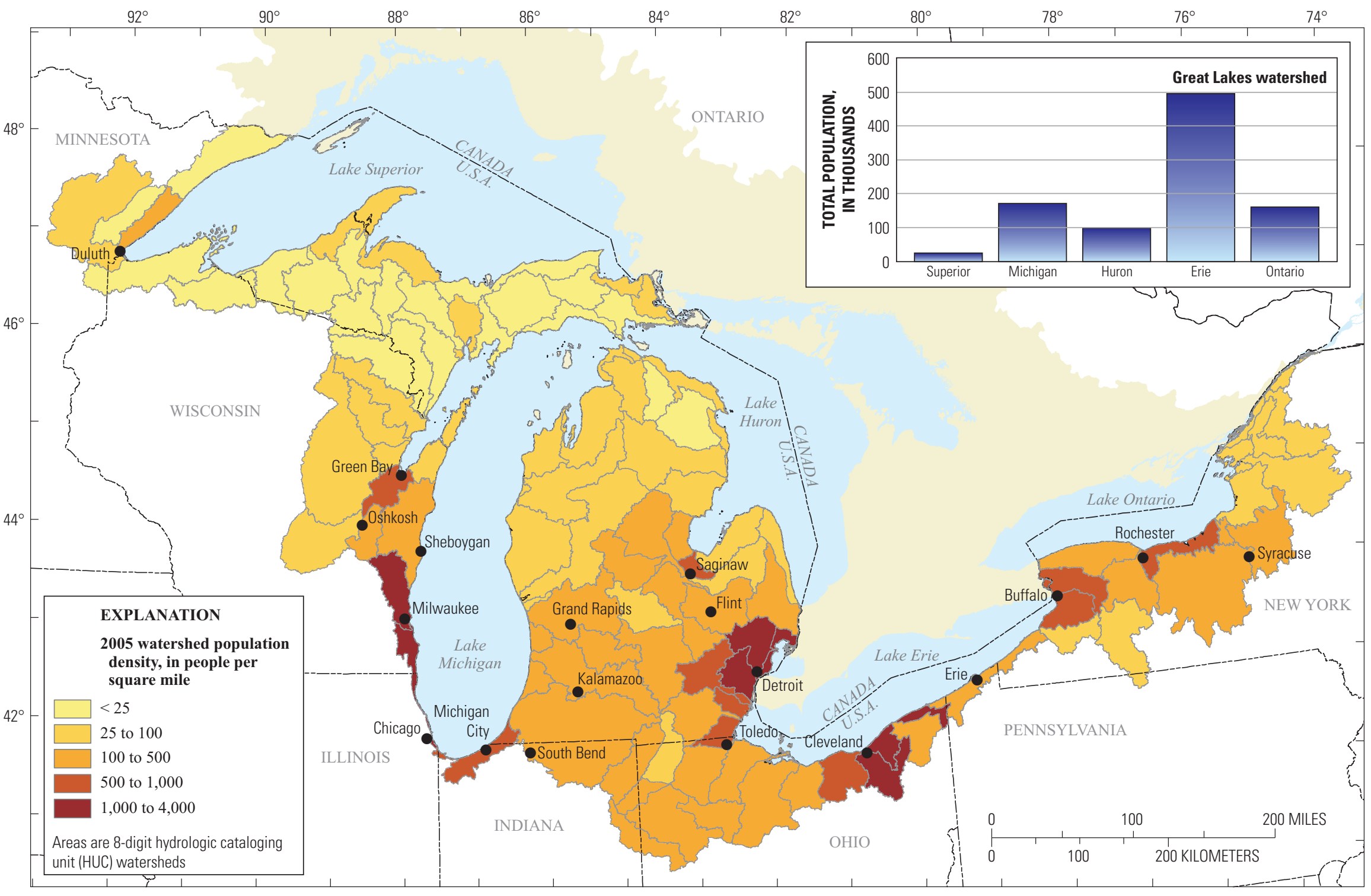

홓

Figure 2. Distribution of population in the Great Lakes Basin, 2005. B, Population density, by watershed. 


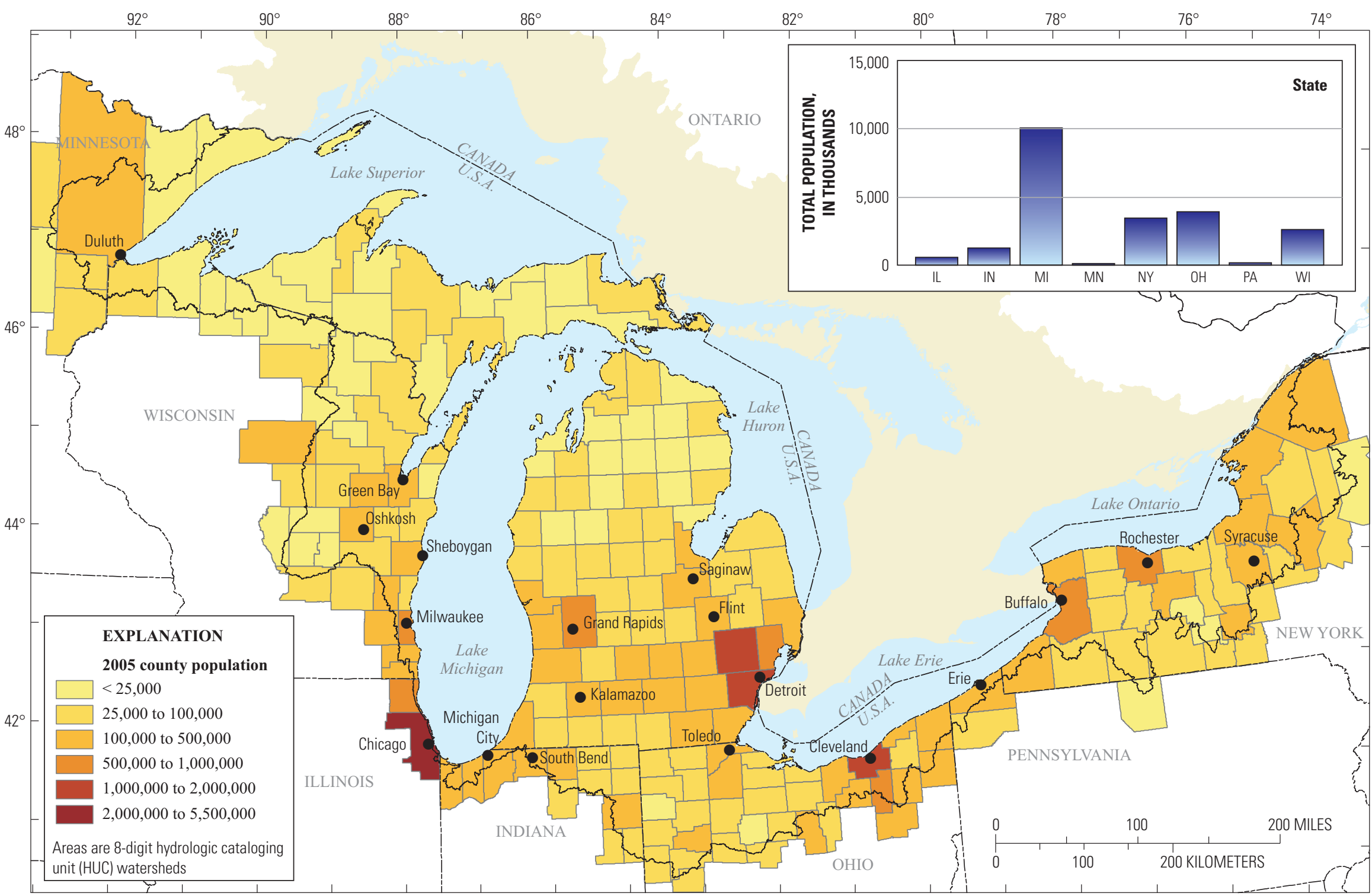

Figure 2. Distribution of population in the Great Lakes Basin, 2005. C, Population, by county (U.S. Department of Commerce, 2001, 2006). 


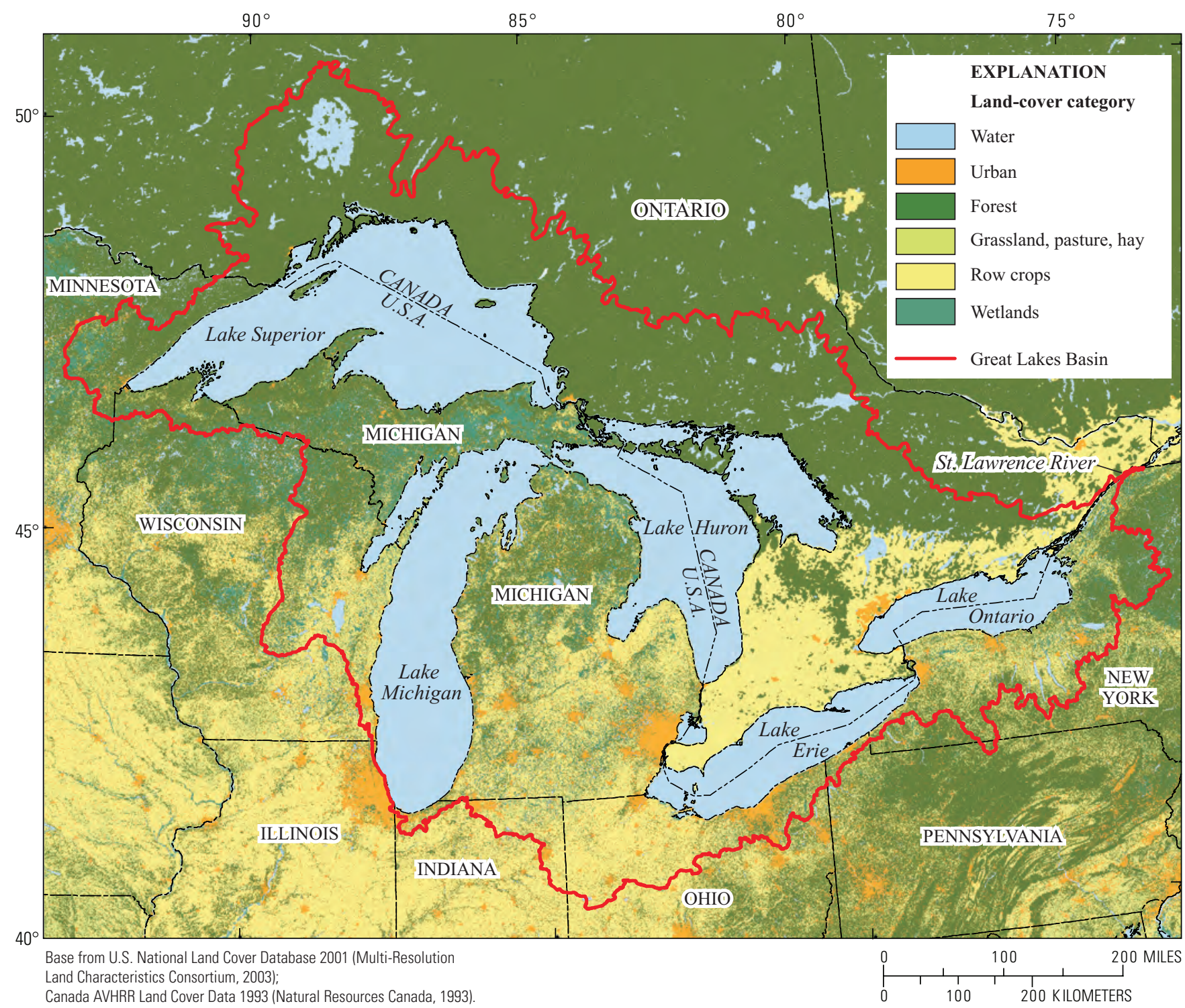

Figure 3. Land cover in the Great Lakes Basin.

Neff and others (2006), and Howard Reeves (U.S. Geological Survey, written commun., 2010). The natural hydrologic system of the basin and the ways it has changed in response to human activity are described in a report by the International Joint Commission (2000).

\section{Sources of Data and Estimates}

The water-use estimates for the Great Lakes Basin HUCs were compiled as part of the larger historical effort by the USGS NWUIP to estimate water use for the Nation at 5-year intervals, an effort that began in 1950 (MacKichan, 1951, 1957; MacKichan and Kammerer, 1961; Murray, 1968; Murray and Reeves, 1972, 1977; Solley and others, 1983, 1988, 1993, 1998; Hutson and others, 2004; and Kenny and others, 2009). In conjunction with this national compilation, water-use estimates were compiled for all 8-digit HUCs in the
Nation and subsequently made publicly available on the World Wide Web (U.S. Geological Survey, 2009) for 1985, 1990, and 1995. This series of national water-use reports serves not only as one of the few sources of information about national or regional trends in water withdrawals but also as a basis for the present report on water withdrawals in the Great Lakes Basin. The format and language of this report borrows extensively from the above-listed reports of the USGS NWUIP and Water Availability Program, GLBP.

Estimates of water withdrawals in the Great Lakes Basin also have been compiled by other agencies and organizations, including the Michigan Sea Grant Program (1985) and the Great Lakes Commission (GLC) (2006), among others for years 1998-2004. The estimates presented in this report differ from these available compilations in several ways. Different time periods are represented; somewhat different data sources, category definitions, and estimations methods are 


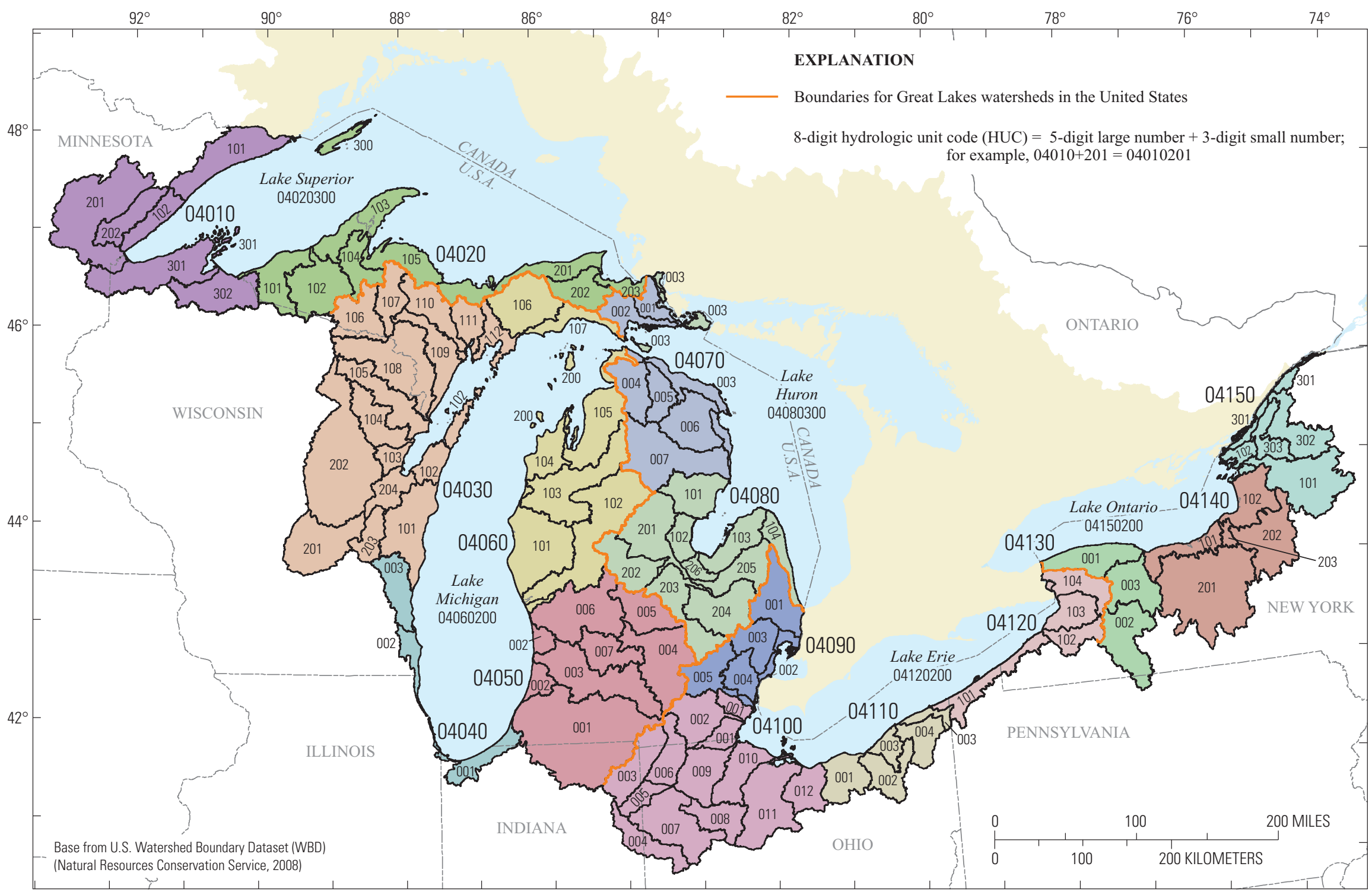

Figure 4. Watersheds of the Great Lakes Basin designated by 8-digit hydrologic (cataloging) unit code (HUC). 
used; and estimates account for different base scales. For this report, withdrawal estimates were complied and presented for 8-digit HUC areas; these estimates were the basis for the withdrawal estimates of larger watershed and basin areas also presented in the report. Estimates provided by the GLC and others typically have been only for the larger areas presented in this report, including the extent of the Great Lakes Basin within each Great Lakes State, the area representing each Great Lake watershed, and (or) the entire basin. In this study, a single approach was employed for most HUCs in the basin for estimation of mining, livestock, and aquaculture withdrawals. The withdrawal accountings of these categories by others, including those of the GLC as provided by their jurisdictional participants (states and provinces), generally rely on a variety of approaches for the estimates. When comparing the various accountings of Great Lakes Basin water withdrawals, it is necessary to recognize that all such accountings, including by the USGS as presented here, are faced with the challenge of estimating withdrawals (and associated elements of water use) on the basis of variable sources, types, and completeness of data and, consequently, on the basis of variable approaches.

The 2005 National and Great Lakes Basin estimates of withdrawals and elements of water use by the USGS were compiled in cooperation with state and local agencies and with the assistance of various Federal agencies and nongovernmental entities. The USGS NWUIP coordinated the compilation effort. The estimates were reviewed at various stages of compilation within the USGS and cooperating agencies and stored in the USGS Aggregate Water-Use Data System (AWUDS). These compiled estimates are available for download from the USGS NWUIP Web site (http://water.usgs.gov/watuse/).

Sources of data and water-use information for estimation of withdrawals and other elements of water use vary by state and are discussed in greater detail in the section "Uncertainty in Estimates" near the end of this report. Guidelines for preparing USGS water-use estimates for 2005 (Hutson, 2007) were developed and distributed to water-use specialists in USGS Water Science Centers, which operate largely at the state level. These specialists compiled and analyzed information from various sources, made estimates of missing data, and prepared documentation that identified the sources of wateruse information and methods used to quantify withdrawals and other aspects of water use for their respective states. For the more specific accounting of estimation methods included in those documents, readers may contact the USGS Water Science Centers for the states of interest. Data sources for the estimations included governmental agencies and nongovernmental entities. Additionally, the USGS NWUIP furnished the USGS Water Science Centers in each Great Lakes State with estimates of county and Great Lakes HUC populations, plus withdrawal estimates for mining, aquaculture, and livestock (Lovelace, 2009a,b,c). Each USGS water-use specialist was responsible for determining the most reliable sources of information available for estimating withdrawals and other elements of water use for his or her state, including determining whether to use all or some of the USGS NWUIP-furnished estimates. Estimates of withdrawals and other indicators of water use for HUCs in the basin aggregated by state, as supplied by the various USGS Water Science Centers, are included in appendix $1 B$; estimates of withdrawals aggregated by HUC are included in appendix $1 C$.

Selected water-use estimates included in this report for various basin HUCs in New York are preliminary; the final USGS NWUIP-approved estimates for these HUCs were not available in time for their incorporation into this water-use evaluation. Consequently, the aggregated estimates for HUCs that are fully or partly in New York and the summarized withdrawals presented for the State of New York and the Lake Erie and Lake Ontario watersheds are somewhat affected. Affected estimates, as determined from the subsequently approved New York estimates (available at http://water.usgs.gov/watuse/), are identified in appendices $1 B$ and $1 C$ by bold typeface.

The differences between the preliminary and final estimates are relatively minor. Affected estimates are restricted to the use categories and elements of public-supply, fresh groundwater (difference in total withdrawals of $0.01 \mathrm{Mgal} / \mathrm{d}$ associated with two HUCs); public-supply, population served (difference in total population of 1 percent); domestic, self-supplied population (difference in total population of 4 percent); domestic, public-supply deliveries (difference in total deliveries of 4 percent); domestic, self-supplied groundwater withdrawals (difference in total withdrawals of 7 percent); industrial, surface-water withdrawals (difference of $0.03 \mathrm{Mgal} / \mathrm{d}$ associated with one HUC); mining, surfacewater (fresh) and groundwater (fresh and saline) withdrawals (difference in total withdrawals of each category less than $0.5 \mathrm{Mgal} / \mathrm{d}$ ); irrigation, golf course and total withdrawals (surface water and groundwater) (difference in total withdrawals of each category less than $1 \mathrm{Mgal} / \mathrm{d}$ ); and irrigation, sprinkler acreage (differences in acreage for all affected HUCs $0.02 \mathrm{Mgal} / \mathrm{d}$ or less).

\section{Terminology Used and Changes for the 2005 National Report}

The terms and units in this report are similar to those used in previous USGS NWUIP reports and are defined in the glossary near the end of the report. Annual withdrawal data are expressed in this report in terms of million gallons per day (abbreviated as Mgal/d), and selectively, in thousand acre-feet per year. The term "billion gallons per day" (one-thousand million gallons per day, abbreviated as Bgal/d) is used in the abstract, summary, and "Trends in Water Withdrawals, 19852005 " sections and in selected illustrations of this report to more simply express large numbers. Units of million gallons per day or billion gallons per day are used to indicate an average daily rate of use and do not represent actual daily rates. For example, even though irrigation water may be applied only part of a year and at variable rates, average daily rate is equal to the total amount of water divided by 365 days. Therefore, the actual rate of application at any given time during the 
growing season, when all the water is withdrawn and applied, would be more than the average daily rate expressed as million gallons per day or billion gallons per day.

The values of water-use data presented in the text and figures generally are rounded to three significant figures. In the tables and appendixes, the values are shown to two decimal places (withdrawal and most other elements of water use, including population-served data) or three decimal places (census-population data). Values of per capita use in the text and appendixes are given as whole numbers. All values are rounded independently; therefore, the sums of individual rounded numbers may not equal the totals. The percentage changes discussed in the text are calculated from the unrounded data and expressed as integers.

For the USGS NWUIP reports for 2005 (and 2000), water use was defined, in a restrictive sense, as water withdrawals (Kenny and others, 2009; Hutson and others, 2004). For reports before 2000, water use was defined as water withdrawals plus deliveries from public-supply deliveries. In a broader sense, water use pertains to the interaction of humans with and influence on the hydrologic cycle and includes elements such as water withdrawal, delivery, consumptive use, wastewater returns, reclaimed wastewater, conveyance loss, and instream use. For this report, "water use" refers specifically to withdrawals but may be used in certain contexts in a broader sense that includes the other estimated elements of use presented in this report (consumptive use, use of reclaimed wastewater, populations served, and irrigated acreage, and so forth).

The number of mandatory water-use reporting categories and associated elements were reduced for the 2005 national compilation, and some states compiled estimates for only the mandatory reporting categories and elements. Principally, the withdrawal estimates for the mandatory categories and elements are included in this compilation of water withdrawals and use in the Great Lakes Basin. Additionally included are estimates of other selected elements of water use. Estimates for the nonmandatory elements of use may not be available for all basin states (and, thus, HUCs) or may be included only as basinwide estimates compiled separately from the national reports, such as those for consumptive use.

For 2005, estimates of self-supplied water withdrawals were compiled for the mandatory categories of public supply, self-supplied domestic, thermoelectric power, industrial, mining, irrigation, livestock, and aquaculture; compilations were for all counties in the United States, as well as for all 8-digit HUCs within the U.S. part of the Great Lakes Basin (county estimates are presented in Kenny and others, 2009). Estimates were compiled for the mandatory elements population served by public supply; domestic deliveries from public supply; domestic self-served population; amount of power generated by thermoelectric powerplants; acreage irrigated by type of irrigation system (sprinkler, microirrigation, or surface application); and reclaimed wastewater use for irrigation and industrial purposes. Data not reported for 2005 (or for 2000) include self-supplied commercial withdrawals; deliveries from public supply for commercial, industrial, and thermoelectric-power purposes; irrigation conveyance loss; consumptive use; instream hydroelectric-power use; and wastewater returns. Estimates of withdrawals for commercial use and golf course irrigation use (a subcategory of total irrigation use) are included for this study (appendix 1), as selectively furnished by USGS Water Science Centers for individual states. Estimates of consumptive use for various categories of use were compiled only by the Ohio Water Science Center; provisional estimates for basin HUCs in Ohio can be found at the USGS NWUIP Web site (http://water.usgs.gov/watuse/).

The mandatory water-use categories generally constitute a comprehensive accounting of water withdrawals in the United States and the Great Lakes Basin. During 2005, 96 percent of total water withdrawals in the United States were used for thermoelectric-power, irrigation, public-supply, industrial, and domestic purposes (Kenny and others, 2009). During 1995, the last national compilation of water use by HUC, 98 percent of total water withdrawals in the Great Lakes Basin was used for the above-listed purposes in aggregate (Solley and others, 1998).

In some respects, the apparent comprehensiveness of the accounting presented in the current study is affected by the exclusion of withdrawals for hydroelectric-power and commercial uses. Hydroelectric-power generation accounts for withdrawals of about $300 \mathrm{Mgal} / \mathrm{d}$ in the U.S. part of the basin (Great Lakes Commission, 2006), or about 10 times the withdrawals accounted for in this study. However, this is an instream use, where all the water that is used is considered to be returned to the basin. Thus, there is no associated consumptive use. As such, for purposes of this study, these large withdrawals need not be considered in the accounting. Although generally excluded in this accounting, commercial withdrawals historically (1985-95) represent only a small fraction (less than 1 percent) of total basin withdrawals; however, the quantities of these withdrawals may routinely be underestimated (Marilee Horn, U.S. Geological Survey, written commun., 2009). Additional discussion on the estimation of commercial withdrawals can be found in the report section "Industrial and Commercial."

For comparison of the estimates of withdrawals from 2005 with past estimates, several other changes in accounting should be noted. For 2005, saline water was defined, for most categories of use, as water that has a concentration of $1,000 \mathrm{mg} / \mathrm{L}$ or more dissolved solids. For public supply, saline water was defined as water that requires desalination or dilution to make it potable. Before 2005, the concentration-based definition for saline water was applied to the thermoelectricpower, industrial, and mining categories. All public-supply, self-supplied domestic, irrigation, livestock, and aquaculture withdrawals were considered or compiled only as freshwater.

Before 2000, thermoelectric-power water use was subdivided by fuel type rather than the type of cooling system (once-through or closed-loop). Cooling-system type is the primary determinant of consumptive use relative to withdrawals at powerplants. Operation of these cooling systems and their relation to consumptive use are described in the report 
sections "Thermoelectric Power" and "Consumptive Use." Also, before 2000, the livestock category was subdivided into livestock and animal specialties; most of these specialties were included in the livestock accounting in subsequent years. Beginning in 2000, one of the former specialties, aquaculture, along with fish hatcheries (formerly reported as self-supplied withdrawals in the commercial category), was introduced as a new category of water use.

\section{Climate and Weather}

Climate (long-term atmospheric conditions) and weather (short-term conditions) affect both the amount of available water resources (such as streams, lakes, and aquifers) and water withdrawals. Precipitation, in the form of rain and snow, contributes to streamflow, lake storage, and aquifer recharge. When conditions are hotter and drier than normal, water resources become stressed. There is less available water and water use increases, particularly for irrigation of crops, lawns, and golf courses.

The Great Lakes Basin lies within the humid-continental climatic region. The climate of the basin varies extensively because of the long north-to-south span of the basin and the effects of the Great Lakes on near-shore temperatures and precipitation. The mean January temperature ranges from $-2^{\circ} \mathrm{F}$ in the north to $28^{\circ} \mathrm{F}$ in the south, and the mean July temperature ranges from $64^{\circ} \mathrm{F}$ in the north to $74^{\circ} \mathrm{F}$ in the south. Precipitation is distributed relatively uniformly throughout the year but varies west to east across the basin, ranging from a mean annual precipitation of $28 \mathrm{in}$. north of Lake Superior to $52 \mathrm{in.}$ east of Lake Ontario (Wilcox and others, 2007).

Statewide weather statistics for the basin states were examined to evaluate possible climatic influences on the withdrawal estimates presented in the report. Temperatures throughout the states composing the basin generally ranged from above normal to much above normal (Minnesota and Wisconsin) during 2005 (National Oceanic and Atmospheric Administration, 2007). Higher than normal temperatures contribute to increased evapotranspiration, and thus, water loss from surface-water bodies and from soil water for groundwater recharge. However, such losses that may have been associated with higher than normal temperatures tended to be countered by generally higher than normal precipitation. Precipitation varied widely across the basin states. In and near the Lake Michigan watershed, precipitation ranged from much below normal (in Illinois) to near normal. Although representing only a small fraction of the entire Great Lakes Basin, precipitation totals in Illinois were among the 11 lowest on record (1895-2005) for the State. Within other parts of the entire basin, precipitation ranged from near normal to much above normal (in Minnesota and New York). The generally normal to wet conditions throughout most of the basin suggest that water resources and withdrawals for irrigation were not affected unusually by weather in 2005. Depending on the seasonal distribution, warmer than normal conditions throughout much of the basin and drier than normal conditions in (and near) Illinois might locally have contributed somewhat to increased withdrawals for thermoelectric power, domestic and public supply, or livestock use.

Although estimates of withdrawals for 2005 are considered here with respect to 2005 basin weather conditions, it should be recognized that there is inherent complexity associated with such considerations. Weather patterns, particularly precipitation patterns, can vary considerably over small areas. Thus, their association with regional trends in water use may be inappropriate. Similarly, there may be time lags associated with weather and climate trends and resultant water use. Finally, not all water-withdrawal estimates presented herein may be fully representative of 2005 use. Some estimates may incorporate use data from years before and after 2005. For example, mining estimates in most states are derived, in part, from 2004 production data; irrigation estimates in several states are derived from 2002 estimates of irrigated acreage.

\section{Withdrawals and Other Elements of Water Use}

Water-use activities begin when water is diverted or withdrawn from surface-water or groundwater sources and conveyed to a place of use. A withdrawal is made by a selfsupplied user or by a public-supply facility (also known as a community water system). A self-supplied user can be a single user or aggregate of users (group of users in a specific geographic area). Accounting for water use generally associates the withdrawal of water for a specific purpose, such as irrigation, industrial processing or manufacture, or domestic activities in a household (such as drinking or bathing).

Withdrawals within the Great Lakes Basin for 2005 were estimated by source and type of water (surface water, groundwater; freshwater, saline water) for the use categories public supply and self-supplied domestic, thermoelectric power, industrial, mining, irrigation, aquaculture, and livestock. Also estimated were quantities of reclaimed wastewater used for irrigation and industry, as well as values of other associated elements of water use that include population, population served by public supply, domestic deliveries from public supply, domestic self-served population, power generated, irrigated acres by type of irrigation, intensity of withdrawals, and gross per capita use. Within the following sections of the report, the withdrawal estimates by source, type, and geographic distribution are discussed and summarized. Also discussed are the estimates of the associated elements of water use.

Summaries by geographic distribution include the 5 Great Lakes watersheds, 8 states (basin areas), and 107 HUCs within the basin. Total withdrawals presented for each of the Great Lakes watersheds (Superior, Michigan, Huron, Erie, or Ontario) include the withdrawals from all HUCs draining directly or indirectly to a single lake. Withdrawals also are 
presented for the HUCs representing each Great Lake. In some cases, these withdrawals include a small percentage ( 2 percent or less) of groundwater associated with mining extractions or wells on lake islands. Withdrawals from the Great Lakes also include those that could be identified from the channels connecting the lakes. These channels include the St. Marys River for Lake Huron; St. Clair River, Lake St. Clair, and Detroit River for Lake Erie; and the Niagara River and St. Lawrence River for Lake Ontario (fig. 1). All withdrawal values given in this report, whether a total from all sources of water (surface water and groundwater) and categories of use, a total by specified source (surface water or groundwater) and category of use, or a total from a specific geographic area (basin, Great Lake watershed, state, or HUC) represent aggregated withdrawals from a number of surface-water intakes and (or) groundwater wells.

\section{Total Withdrawals and Source of Water}

Total water withdrawals in the Great Lakes Basin for 2005 are summarized by source of water, geographic distribution, and category of use in figures 5 and 6 and tables 1 and 2. For individual HUCs, withdrawals by category of use and other elements of water use are listed in appendix 1.

For 2005, freshwater and saline-water withdrawals from surface-water and groundwater sources totaled 30,300 Mgal/d. About 24,100 Mgal/d (79 percent) of the withdrawals were from HUCs representing the five Great Lakes or their connecting channels, with less than 0.04 percent of the withdrawals from these HUCs as groundwater. Saline water represented less than 0.004 percent of the total water withdrawn.

Although saline-water withdrawals represent only a small fraction of total withdrawals, the quantity of saline withdrawals might be nominally greater than estimated in this assessment. For the compilation, water for most uses other than public supply is classified as saline if it contains $1,000 \mathrm{mg} / \mathrm{L}$ or more dissolved solids. In most cases, data were not readily available on the chemistry of the water withdrawals, so reportings generally assume freshwater withdrawals. The likelihood for dissolved solids concentrations of greater than 1,000 mg/L is greatest with groundwater withdrawn from the deep aquifers near the base of the (geological) Illinois and Michigan Basins in Illinois, Indiana, and Michigan (Miller, 2000). Saline waters also are present where naturally occurring salt deposits and saline springs are common, as in parts of New York, Ohio, and Michigan where salt is mined (Sanford, 1995; Encyclopedia of Cleveland History, 2003; Michigan Department of Environmental Quality, 1994).

Estimates of withdrawals, by source, indicate that surface-water withdrawals for 2005 totaled $28,800 \mathrm{Mgal} / \mathrm{d}$, or 95 percent of the total withdrawals for all categories of use; about 24,000 Mgal/d was withdrawn from HUCs representing the Great Lakes or their connecting channels. Groundwater withdrawals totaled $1,500 \mathrm{Mgal} / \mathrm{d}$, of which about 0.08 percent was saline water. Given the insubstantial fraction of total (and groundwater) withdrawals representing saline withdrawals, most presentations in this report of withdrawals (as volumes or percentages) by category of use are as total withdrawals. For the most part, these total withdrawals also represent total freshwater withdrawals. A distinction between total withdrawals and total freshwater withdrawals is made only for the single category of use that included saline withdrawals: mining withdrawals from groundwater sources.

The largest total water withdrawals were for thermoelectric-power use, at 21,900 Mgal/d or 72 percent of total withdrawals; an estimated 2 percent of this water is consumed, and the remainder is returned to the source at the once-through cooling-system-based plants that are predominant in the basin (Shaffer and Runkle, 2007). Public supply accounted for 3,810 Mgal/d (13 percent of withdrawals) and industrial use, $2,930 \mathrm{Mgal} / \mathrm{d}$ (10 percent). Mining and irrigation each accounted for 2 percent of withdrawals; self-supplied domestic, aquaculture, and livestock use each accounted for 1 percent or less of withdrawals.

More surface water than groundwater was withdrawn in all categories of use except self-supplied domestic, irrigation, and livestock use (tables 3 and 4). About 76 percent $(21,900$ $\mathrm{Mgal} / \mathrm{d}$ ) of the surface-water withdrawals were for thermoelectric power and 12 percent $(3,350 \mathrm{Mgal} / \mathrm{d})$ were for public supply. The largest total withdrawal, 15,000 Mgal/d (49 percent of withdrawals), was from the Lake Michigan watershed (largest watershed, at 39 percent of the basin land area), as was the largest surface-water withdrawal, at 14,000 Mgal/d (49 percent). Most of the withdrawals (10,300 Mgal/d) from the watershed were surface-water withdrawals for thermoelectric-power generation. The Lake Michigan watershed also accounted for the largest surface-water withdrawals for public supply, industrial, irrigation, and aquaculture use. By Great Lakes States within the basin, the largest total withdrawal, $11,700 \mathrm{Mgal} / \mathrm{d}$ (38 percent of withdrawals), was in Michigan (largest state area, at 51 percent of the basin land area), as was the largest surface-water withdrawal, at 10,800 Mgal/d (38 percent). Most of the withdrawals from Michigan were surface-water withdrawals for thermoelectric-power generation $(9,140 \mathrm{Mgal} / \mathrm{d})$. Michigan also accounted for the largest surface-water withdrawals for irrigation and aquaculture uses. Illinois accounted for the largest surface-water withdrawals for public supply $(1,020 \mathrm{Mgal} / \mathrm{d})$; those withdrawals serve the residents of metropolitan Chicago, about 90 percent of whom reside outside the basin.

Most groundwater withdrawals, about 58 percent, were distributed about equally between public-supply and self-supplied domestic use; irrigation use accounted for an additional 23 percent of groundwater withdrawals (table 4). About 63 percent $(950 \mathrm{Mgal} / \mathrm{d})$ of the groundwater withdrawals were in the Lake Michigan watershed; about 64 percent of these withdrawals in the watershed were distributed almost equally between irrigation and public-supply use. About 56 percent of the groundwater withdrawals were in Michigan; about 61 percent of the withdrawals in the State were distributed almost equally between public supply and self-supplied 

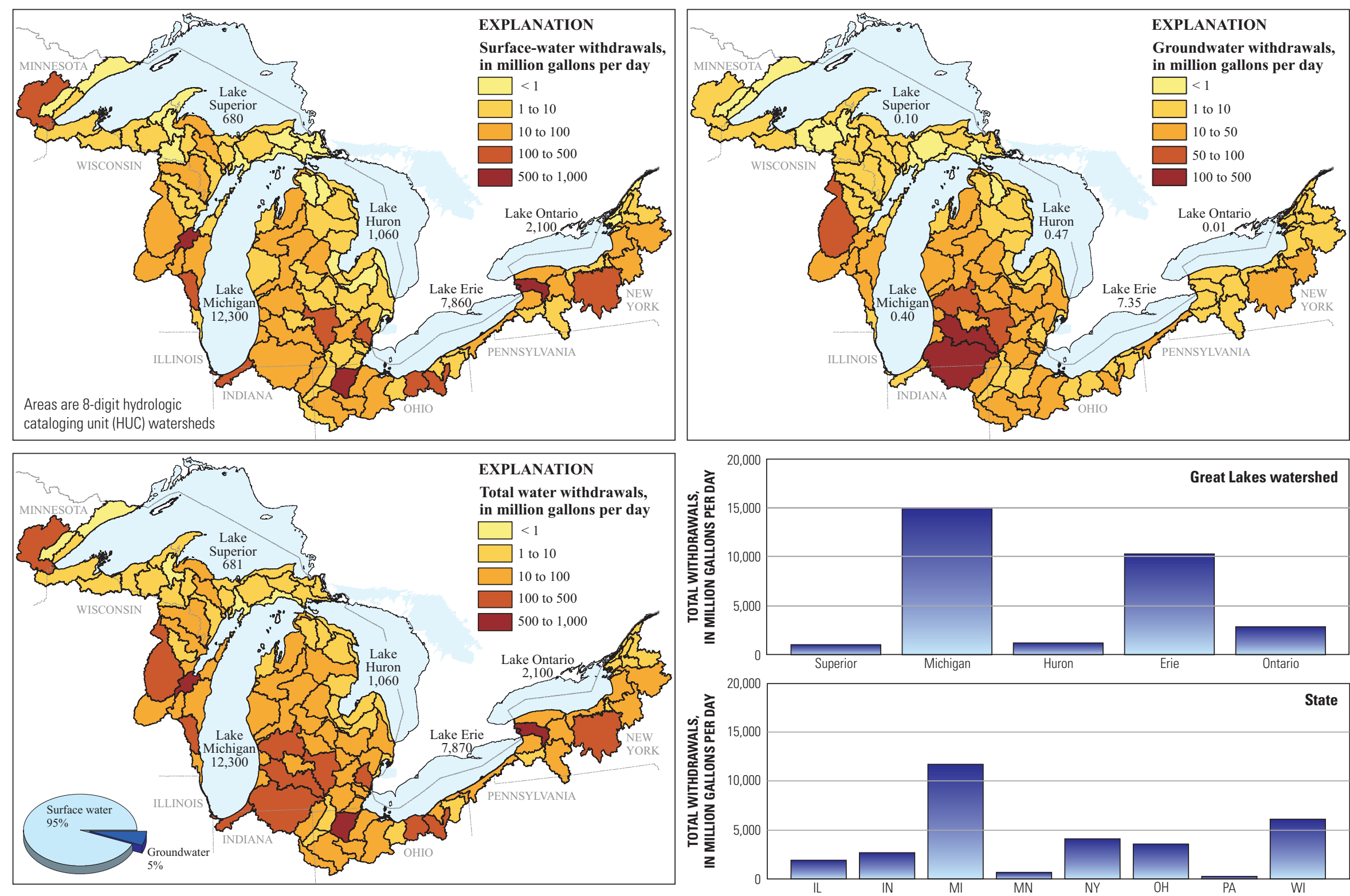

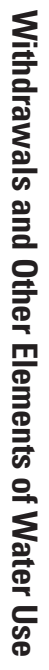

Figure 5. Total, surface-water, and groundwater withdrawals in the Great Lakes Basin, 2005. 

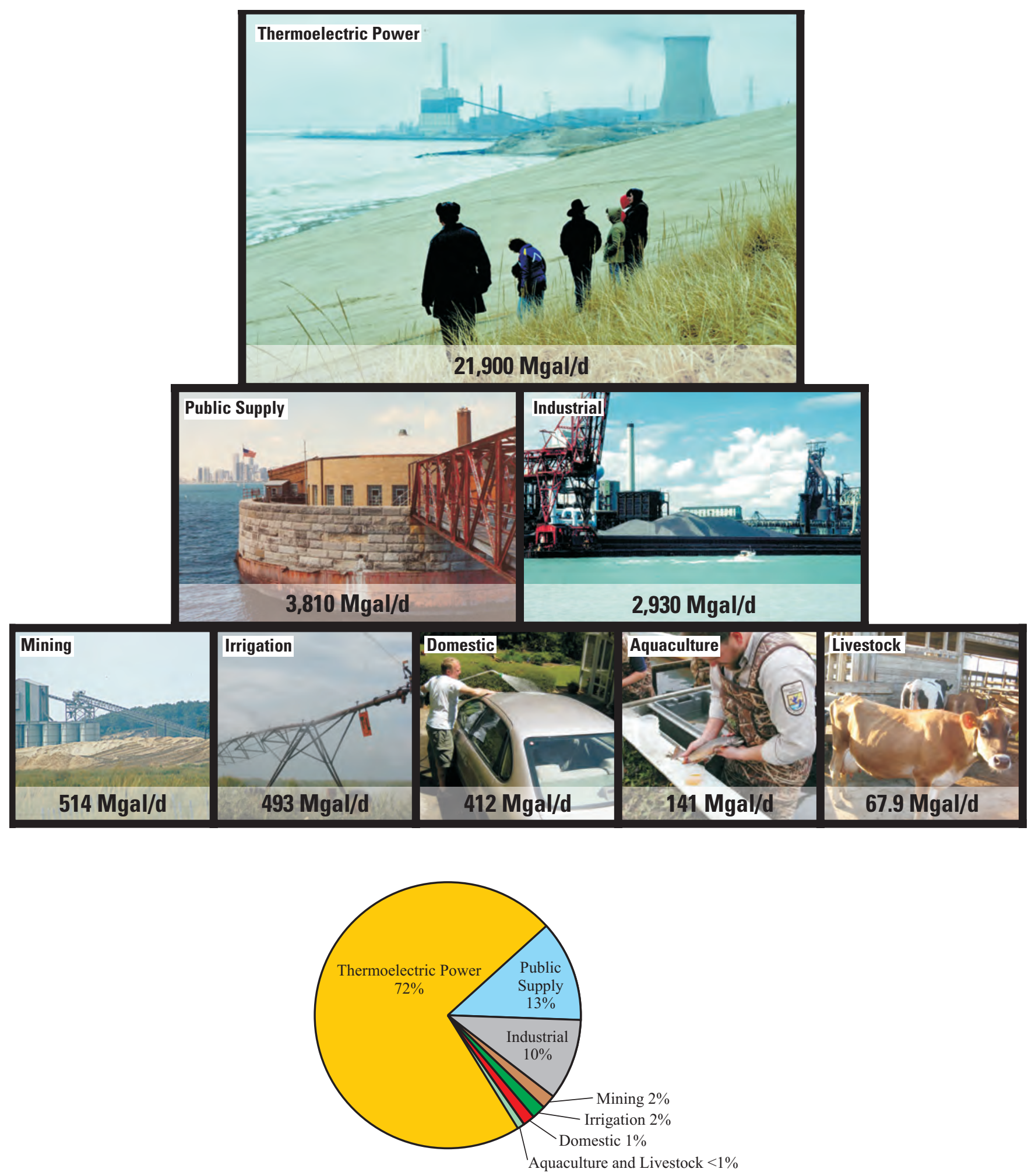

Figure 6. Total withdrawals by water-use category in the Great Lakes Basin, 2005 (values in percentage of water use in million gallons per day; aquaculture and livestock use less than 1 percent of total use; photo credits are on inside of front cover). 
Table 1. Total water withdrawals by source for Great Lakes watersheds and states in the Great Lakes Basin, 2005.

[Figures may not sum to totals because of independent rounding]

\begin{tabular}{|c|c|c|c|c|c|c|c|c|c|c|c|}
\hline \multirow[b]{4}{*}{$\begin{array}{c}\text { Great Lakes } \\
\text { watershed }\end{array}$} & \multirow[b]{4}{*}{$\begin{array}{c}\text { Land area', } \\
\text { in square miles }\end{array}$} & \multirow[b]{4}{*}{$\begin{array}{l}\text { Population, } \\
\text { in thousands }\end{array}$} & \multicolumn{9}{|c|}{ Withdrawals, in million gallons per day } \\
\hline & & & \multicolumn{6}{|c|}{ By source and type } & \multirow{2}{*}{\multicolumn{3}{|c|}{ Total }} \\
\hline & & & \multicolumn{3}{|c|}{ Surface water } & \multicolumn{3}{|c|}{ Groundwater } & & & \\
\hline & & & Fresh & Saline & Total & Fresh & Saline & Total & Fresh & Saline & Total \\
\hline Superior & 16,783 & 431.114 & 968.43 & 0.00 & 968.43 & 33.94 & 0.00 & 33.94 & $1,002.37$ & 0.00 & $1,002.37$ \\
\hline Michigan & 44,779 & $7,711.612$ & $14,047.26$ & .00 & $14,047.26$ & 950.19 & .72 & 950.91 & $14,997.45$ & .72 & $14,998.17$ \\
\hline Huron & 16,229 & $1,617.285$ & $1,103.99$ & .00 & $1,103.99$ & 123.40 & .14 & 123.54 & $1,227.39$ & .14 & $1,227.53$ \\
\hline Erie & 21,783 & $10,800.648$ & $9,952.29$ & .00 & $9,952.29$ & 307.68 & .20 & 307.88 & $10,259.97$ & .20 & $10,260.17$ \\
\hline Ontario & 14,652 & $2,349.828$ & $2,731.91$ & .00 & $2,731.91$ & 89.23 & .14 & 89.37 & $2,821.14$ & .14 & $2,821.28$ \\
\hline TOTAL & 114,226 & $22,910.487$ & $28,803.88$ & .00 & $28,803.88$ & $1,504.44$ & 1.20 & $1,505.64$ & $30,308.32$ & 1.20 & $30,309.52$ \\
\hline
\end{tabular}

${ }^{1}$ Area of individual watersheds designated by 8-digit hydrologic unit code (HUCs) and the Great Lake within each Great Lake watershed are given in appendix $1 C$.

\begin{tabular}{|c|c|c|c|c|c|c|c|c|c|c|c|}
\hline \multirow[b]{4}{*}{ State } & \multirow[b]{4}{*}{$\begin{array}{c}\text { Land area', } \\
\text { in square miles }\end{array}$} & \multirow[b]{4}{*}{$\begin{array}{l}\text { Population, } \\
\text { in thousands }\end{array}$} & \multicolumn{9}{|c|}{ Withdrawals, in million gallons per day } \\
\hline & & & \multicolumn{6}{|c|}{ By source and type } & & & \\
\hline & & & \multicolumn{3}{|c|}{ Surface water } & \multicolumn{3}{|c|}{ Groundwater } & \multicolumn{3}{|c|}{ Total } \\
\hline & & & Fresh & Saline & Total & Fresh & Saline & Total & Fresh & Saline & Total \\
\hline Illinois & 90 & 667.500 & $1,800.81$ & 0.00 & $1,800.81$ & 0.53 & 0.00 & 0.53 & $1,801.34$ & 0.00 & $1,801.34$ \\
\hline Indiana & 3,483 & 1369.794 & $2,462.96$ & .00 & $2,462.96$ & 130.81 & .00 & 130.81 & $2,593.77$ & .00 & $2,593.77$ \\
\hline Michigan & 58,107 & 10120.859 & $10,823.12$ & .00 & $10,823.12$ & 835.80 & .95 & 836.75 & $11,658.92$ & .95 & $11,659.87$ \\
\hline Minnesota & 6,253 & 215.094 & 587.85 & .00 & 587.85 & 9.96 & .00 & 9.96 & 597.81 & .00 & 597.81 \\
\hline New York ${ }^{2}$ & 16,926 & 3551.985 & $3,975.26$ & .00 & $3,975.26$ & 110.72 & .25 & 110.97 & $4,085.98$ & .25 & $4,086.23$ \\
\hline Ohio & 11,600 & 4014.374 & 3,399.99 & .00 & $3,399.99$ & 132.80 & .00 & 132.80 & $3,532.79$ & .00 & $3,532.79$ \\
\hline Pennsylvania & 607 & 263.822 & 40.98 & .00 & 40.98 & 7.65 & .00 & 7.65 & 48.63 & .00 & 48.63 \\
\hline Wisconsin & 17,160 & 2707.059 & $5,712.91$ & .00 & $5,712.91$ & 276.17 & .00 & 276.17 & $5,989.08$ & .00 & $5,989.08$ \\
\hline TOTAL & 114,226 & 22910.487 & $28,803.88$ & .00 & $28,803.88$ & $1,504.44$ & 1.20 & $1,505.64$ & $30,308.32$ & 1.20 & $30,309.52$ \\
\hline
\end{tabular}

${ }^{1}$ Area of individual HUCs and the Great Lake within each state are given in appendix $1 B$.

${ }^{2}$ Area does not include HUCs 04150304 to 04150307 (3,540 square miles) that are partially in Canada and whose surface-water discharge is to the St. Lawrence River outside the U.S. part of the Great Lakes Basin; the areas of these HUCs are given in appendix $1 B$. 
Table 2. Total water withdrawals by water-use category for Great Lakes watersheds and states in the Great Lakes Basin, 2005.

[Figures may not sum to totals because of independent rounding. All values are in million gallons per day]

\begin{tabular}{|c|c|c|c|c|c|c|c|c|c|c|c|c|c|}
\hline \multirow{2}{*}{$\begin{array}{l}\text { Great Lakes } \\
\text { watershed }\end{array}$} & \multirow{2}{*}{$\begin{array}{c}\text { Public } \\
\text { supply } \\
\text { Fresh }\end{array}$} & \multirow{2}{*}{$\begin{array}{c}\text { Domestic } \\
\text { Fresh }\end{array}$} & \multicolumn{2}{|c|}{$\begin{array}{c}\text { Thermoelectric } \\
\text { power }\end{array}$} & \multicolumn{2}{|c|}{ Industrial } & \multicolumn{2}{|c|}{ Mining } & \multirow{2}{*}{$\begin{array}{c}\text { Irrigation } \\
\text { Fresh }\end{array}$} & \multirow{2}{*}{$\begin{array}{c}\text { Aquaculture } \\
\text { Fresh }\end{array}$} & \multirow{2}{*}{$\begin{array}{c}\text { Livestock } \\
\text { Fresh }\end{array}$} & \multicolumn{2}{|c|}{ Total } \\
\hline & & & Fresh & Saline & Fresh & Saline & Fresh & Saline & & & & Fresh & Saline \\
\hline Superior & 57.03 & 7.81 & 511.47 & 0.00 & 23.16 & 0.00 & 374.11 & 0.00 & 1.46 & 26.59 & 0.74 & $1,002.37$ & 0.00 \\
\hline Michigan & $1,782.88$ & 178.52 & $10,338.31$ & .00 & $2,116.99$ & .00 & 60.61 & .72 & 403.80 & 79.65 & 36.69 & $14,997.45$ & .72 \\
\hline Huron & 256.93 & 68.41 & 815.64 & .00 & 34.71 & .00 & 10.82 & .14 & 27.11 & 8.64 & 5.13 & $1,227.39$ & .14 \\
\hline Erie & $1,387.02$ & 117.45 & $7,933.66$ & .00 & 691.91 & .00 & 58.19 & .20 & 45.76 & 13.39 & 12.59 & $10,259.97$ & .20 \\
\hline Ontario & 327.30 & 40.20 & $2,340.90$ & .00 & 63.10 & .00 & 8.68 & .14 & 15.35 & 12.90 & 12.71 & $2,821.14$ & .14 \\
\hline TOTAL & $3,811.16$ & 412.39 & $21,939.98$ & .00 & $2,929.87$ & .00 & 512.41 & 1.20 & 493.48 & 141.17 & 67.86 & $30,308.32$ & 1.20 \\
\hline \multirow[t]{2}{*}{ State } & \multirow{2}{*}{$\begin{array}{l}\text { Public } \\
\text { supply } \\
\text { Fresh }\end{array}$} & \multirow{2}{*}{$\begin{array}{c}\text { Domestic } \\
\text { Fresh }\end{array}$} & \multicolumn{2}{|c|}{$\begin{array}{c}\text { Thermoelectric } \\
\text { power }\end{array}$} & \multicolumn{2}{|c|}{ Industrial } & \multicolumn{2}{|c|}{ Mining } & \multirow{2}{*}{$\begin{array}{c}\text { Irrigation } \\
\text { Fresh } \\
\end{array}$} & \multirow{2}{*}{$\begin{array}{c}\text { Aquaculture } \\
\text { Fresh }\end{array}$} & \multirow{2}{*}{$\begin{array}{c}\text { Livestock } \\
\text { Fresh } \\
\end{array}$} & \multicolumn{2}{|c|}{ Total } \\
\hline & & & Fresh & Saline & Fresh & Saline & Fresh & Saline & & & & Fresh & Saline \\
\hline Illinois & $1,023.71$ & 0.08 & 758.32 & 0.00 & 18.52 & 0.00 & 0.00 & 0.00 & 0.71 & 0.00 & 0.00 & $1,801.34$ & 0.00 \\
\hline Indiana & 170.82 & 27.90 & 728.13 & .00 & $1,624.59$ & .00 & 4.42 & .00 & 32.11 & .00 & 5.80 & $2,593.77$ & .00 \\
\hline Michigan & $1,142.76$ & 250.95 & $9,148.91$ & .00 & 628.76 & .00 & 94.55 & .95 & 308.08 & 65.34 & 19.57 & $11,658.92$ & .95 \\
\hline Minnesota & 40.29 & 3.22 & 190.34 & .00 & 7.77 & .00 & 354.76 & .00 & .40 & .79 & .24 & 597.81 & .00 \\
\hline New York & 516.59 & 51.55 & $3,362.80$ & .00 & 94.49 & .00 & 10.67 & .25 & 20.23 & 14.34 & 15.31 & $4,085.98$ & .25 \\
\hline Ohio & 567.00 & 47.86 & $2,517.99$ & .00 & 335.54 & .00 & 36.93 & .00 & 17.71 & 4.04 & 5.72 & $3,532.79$ & .00 \\
\hline Pennsylvania & 33.61 & 2.36 & 0.00 & .00 & 5.23 & .00 & .56 & .00 & .59 & 5.79 & .49 & 48.63 & .00 \\
\hline Wisconsin & 316.38 & 28.47 & $5,233.49$ & .00 & 214.97 & .00 & 10.52 & .00 & 113.65 & 50.87 & 20.73 & $5,989.08$ & .00 \\
\hline TOTAL & $3,811.16$ & 412.39 & $21,939.98$ & .00 & $2,929.87$ & .00 & 512.41 & 1.20 & 493.48 & 141.17 & 67.86 & $30,308.32$ & 1.20 \\
\hline
\end{tabular}


Table 3. Surface-water withdrawals by water-use category for Great Lakes watersheds and states in the Great Lakes Basin, 2005.

[Figures may not sum to totals because of independent rounding. All values are in million gallons per day]

\begin{tabular}{|c|c|c|c|c|c|c|c|c|c|c|c|c|c|}
\hline \multirow{2}{*}{$\begin{array}{l}\text { Great Lakes } \\
\text { watershed }\end{array}$} & \multirow{2}{*}{$\begin{array}{c}\text { Public } \\
\text { supply } \\
\text { Fresh }\end{array}$} & \multirow{2}{*}{$\begin{array}{c}\text { Domestic } \\
\text { Fresh }\end{array}$} & \multicolumn{2}{|c|}{$\begin{array}{c}\text { Thermoelectric } \\
\text { power }\end{array}$} & \multicolumn{2}{|c|}{ Industrial } & \multicolumn{2}{|c|}{ Mining } & \multirow{2}{*}{$\begin{array}{c}\text { Irrigation } \\
\text { Fresh }\end{array}$} & \multirow{2}{*}{$\begin{array}{c}\text { Aquaculture } \\
\text { Fresh }\end{array}$} & \multirow{2}{*}{$\begin{array}{c}\text { Livestock } \\
\text { Fresh }\end{array}$} & \multicolumn{2}{|c|}{ Total } \\
\hline & & & Fresh & Saline & Fresh & Saline & Fresh & Saline & & & & Fresh & Saline \\
\hline Superior & 42.49 & 0.00 & 511.36 & 0.00 & 22.62 & 0.00 & 369.74 & 0.00 & 0.75 & 21.44 & 0.03 & 968.43 & 0.00 \\
\hline Michigan & $1,487.48$ & .00 & $10,334.52$ & .00 & $2,012.77$ & .00 & 49.03 & .00 & 93.42 & 65.17 & 4.87 & $14,047.26$ & .00 \\
\hline Huron & 225.43 & .00 & 814.42 & .00 & 32.73 & .00 & 10.45 & .00 & 13.24 & 7.25 & .47 & $1,103.99$ & .00 \\
\hline Erie & $1,293.21$ & .96 & $7,933.30$ & .00 & 656.91 & .00 & 22.90 & .00 & 30.39 & 8.78 & 5.84 & $9,952.29$ & .00 \\
\hline Ontario & 304.46 & .00 & $2,340.90$ & .00 & 54.73 & .00 & 6.98 & .00 & 10.70 & 9.68 & 4.46 & $2,731.91$ & .00 \\
\hline TOTAL & $3,353.07$ & .96 & $21,934.50$ & .00 & $2,779.76$ & .00 & 459.10 & .00 & 148.50 & 112.32 & 15.67 & $28,803.88$ & .00 \\
\hline
\end{tabular}

\begin{tabular}{|c|c|c|c|c|c|c|c|c|c|c|c|c|c|}
\hline \multirow[b]{2}{*}{ State } & \multirow{2}{*}{$\begin{array}{l}\text { Public } \\
\text { supply } \\
\text { Fresh }\end{array}$} & \multirow{2}{*}{$\begin{array}{c}\text { Domestic } \\
\text { Fresh }\end{array}$} & \multicolumn{2}{|c|}{$\begin{array}{c}\text { Thermoelectric } \\
\text { power }\end{array}$} & \multicolumn{2}{|c|}{ Industrial } & \multicolumn{2}{|c|}{ Mining } & \multirow{2}{*}{$\begin{array}{l}\text { Irrigation } \\
\text { Fresh }\end{array}$} & \multirow{2}{*}{$\begin{array}{c}\text { Aquaculture } \\
\text { Fresh }\end{array}$} & \multirow{2}{*}{$\begin{array}{c}\text { Livestock } \\
\text { Fresh }\end{array}$} & \multicolumn{2}{|c|}{ Total } \\
\hline & & & Fresh & Saline & Fresh & Saline & Fresh & Saline & & & & Fresh & Saline \\
\hline Illinois & $1,023.70$ & 0.00 & 758.32 & 0.00 & 18.52 & 0.00 & 0.00 & 0.00 & 0.27 & 0.00 & 0.00 & $1,800.81$ & 0.00 \\
\hline Indiana & 110.08 & .00 & 727.86 & .00 & $1,613.51$ & .00 & 4.05 & .00 & 5.23 & .00 & 2.23 & $2,462.96$ & .00 \\
\hline Michigan & 882.61 & .00 & $9,144.84$ & .00 & 539.66 & .00 & 81.35 & .00 & 110.41 & 62.39 & 1.86 & $10,823.12$ & .00 \\
\hline Minnesota & 34.30 & .00 & 190.23 & .00 & 7.76 & .00 & 354.74 & .00 & .39 & .43 & .00 & 587.85 & .00 \\
\hline New York & 490.64 & .00 & $3,362.80$ & .00 & 84.14 & .00 & 8.61 & .00 & 14.05 & 9.64 & 5.38 & $3,975.26$ & .00 \\
\hline Ohio & 533.44 & .96 & $2,517.99$ & .00 & 320.71 & .00 & 5.51 & .00 & 13.65 & 3.66 & 4.07 & 3,399.99 & .00 \\
\hline Pennsylvania & 31.36 & .00 & .00 & .00 & 5.21 & .00 & .45 & .00 & .45 & 3.45 & .06 & 40.98 & .00 \\
\hline Wisconsin & 246.94 & .00 & $5,232.46$ & .00 & 190.25 & .00 & 4.39 & .00 & 4.05 & 32.75 & 2.07 & $5,712.91$ & .00 \\
\hline TOTAL & $3,353.07$ & .96 & $21,934.50$ & .00 & $2,779.76$ & .00 & 459.10 & .00 & 148.50 & 112.32 & 15.67 & $28,803.88$ & .00 \\
\hline
\end{tabular}


Table 4. Groundwater withdrawals by water-use category for Great Lakes watersheds and states in the Great Lakes Basin, 2005.

[Figures may not sum to totals because of independent rounding. All values are in million gallons per day]

\begin{tabular}{|c|c|c|c|c|c|c|c|c|c|c|c|c|c|}
\hline \multirow{2}{*}{$\begin{array}{l}\text { Great Lakes } \\
\text { watershed }\end{array}$} & \multirow{2}{*}{$\begin{array}{c}\text { Public } \\
\text { supply } \\
\text { Fresh }\end{array}$} & \multirow{2}{*}{$\begin{array}{c}\text { Domestic } \\
\text { Fresh }\end{array}$} & \multicolumn{2}{|c|}{$\begin{array}{c}\text { Thermoelectric } \\
\text { power }\end{array}$} & \multicolumn{2}{|c|}{ Industrial } & \multicolumn{2}{|c|}{ Mining } & \multirow{2}{*}{$\begin{array}{l}\text { Irrigation } \\
\text { Fresh }\end{array}$} & \multirow{2}{*}{$\begin{array}{c}\text { Aquaculture } \\
\text { Fresh }\end{array}$} & \multirow{2}{*}{$\begin{array}{l}\text { Livestock } \\
\text { Fresh }\end{array}$} & \multicolumn{2}{|c|}{ Total } \\
\hline & & & Fresh & Saline & Fresh & Saline & Fresh & Saline & & & & Fresh & Saline \\
\hline Superior & 14.54 & 7.81 & 0.11 & 0.00 & 0.54 & 0.00 & 4.37 & 0.00 & 0.71 & 5.15 & 0.71 & 33.94 & 0.00 \\
\hline Michigan & 295.40 & 178.52 & 3.79 & .00 & 104.22 & .00 & 11.58 & .72 & 310.38 & 14.48 & 31.82 & 950.19 & .72 \\
\hline Huron & 31.50 & 68.41 & 1.22 & .00 & 1.98 & .00 & .37 & .14 & 13.87 & 1.39 & 4.66 & 123.40 & .14 \\
\hline Erie & 93.81 & 116.49 & .36 & .00 & 35.00 & .00 & 35.29 & .20 & 15.37 & 4.61 & 6.75 & 307.68 & .20 \\
\hline Ontario & 22.84 & 40.20 & .00 & .00 & 8.37 & .00 & 1.70 & .14 & 4.65 & 3.22 & 8.25 & 89.23 & .14 \\
\hline \multirow[t]{2}{*}{ TOTAL } & 458.09 & 411.43 & 5.48 & .00 & 150.11 & .00 & 53.31 & 1.20 & 344.98 & 28.85 & 52.19 & $1,504.44$ & 1.20 \\
\hline & \multirow{2}{*}{$\begin{array}{l}\text { Public } \\
\text { supply } \\
\text { Fresh }\end{array}$} & \multirow{2}{*}{$\begin{array}{c}\text { Domestic } \\
\text { Fresh }\end{array}$} & \multicolumn{2}{|c|}{$\begin{array}{c}\text { Thermoelectric } \\
\text { power }\end{array}$} & \multicolumn{2}{|c|}{ Industrial } & \multicolumn{2}{|c|}{ Mining } & \multirow{2}{*}{$\begin{array}{c}\text { Irrigation } \\
\text { Fresh }\end{array}$} & \multirow{2}{*}{$\begin{array}{c}\text { Aquaculture } \\
\text { Fresh }\end{array}$} & \multirow{2}{*}{$\begin{array}{c}\text { Livestock } \\
\text { Fresh }\end{array}$} & \multicolumn{2}{|c|}{ Total } \\
\hline State & & & Fresh & Saline & Fresh & Saline & Fresh & Saline & & & & Fresh & Saline \\
\hline Illinois & 0.01 & 0.08 & 0.00 & 0.00 & 0.00 & 0.00 & 0.00 & 0.00 & 0.44 & 0.00 & 0.00 & 0.53 & 0.00 \\
\hline Indiana & 60.74 & 27.90 & .27 & .00 & 11.08 & .00 & .37 & .00 & 26.88 & .00 & 3.57 & 130.81 & .00 \\
\hline Michigan & 260.15 & 250.95 & 4.07 & .00 & 89.10 & .00 & 13.20 & .95 & 197.67 & 2.95 & 17.71 & 835.80 & .95 \\
\hline Minnesota & 5.99 & 3.22 & .11 & .00 & .01 & .00 & .02 & .00 & .01 & .36 & .24 & 9.96 & .00 \\
\hline New York & 25.95 & 51.55 & .00 & .00 & 10.35 & .00 & 2.06 & .25 & 6.18 & 4.70 & 9.93 & 110.72 & .25 \\
\hline Ohio & 33.56 & 46.90 & .00 & .00 & 14.83 & .00 & 31.42 & .00 & 4.06 & .38 & 1.65 & 132.80 & .00 \\
\hline Pennsylvania & 2.25 & 2.36 & .00 & .00 & .02 & .00 & .11 & .00 & .14 & 2.34 & .43 & 7.65 & .00 \\
\hline Wisconsin & 69.44 & 28.47 & 1.03 & .00 & 24.72 & $\begin{array}{l}.00 \\
.00\end{array}$ & 6.13 & .00 & 109.60 & 18.12 & 18.66 & 276.17 & .00 \\
\hline TOTAL & 458.09 & 411.43 & 5.48 & .00 & 150.11 & .00 & 53.31 & 1.20 & 344.98 & 28.85 & 52.19 & $1,504.44$ & 1.20 \\
\hline
\end{tabular}


domestic use. In addition to the large percentage of basin land area represented by the Lake Michigan watershed and the state of Michigan, both areas are underlain by extensive unconsolidated and bedrock aquifers (Miller, 2000).

The distributions of total, total surface-water, and total groundwater withdrawals by HUC are shown in figure 5 . Withdrawals from the HUC representing Lake Michigan (hereafter each Great Lake HUC is referred to solely by the name of the lake) accounted for the majority of the total withdrawal (41 percent; $12,300 \mathrm{Mgal} / \mathrm{d} ; 0.4 \mathrm{Mgal} / \mathrm{d}$ as groundwater) and total surface-water withdrawal (43 percent; $12,300 \mathrm{Mgal} / \mathrm{d}$ ) in the basin. Lake Erie accounted for an additional 7,870 Mgal/d of total withdrawal $(7.35 \mathrm{Mgal} / \mathrm{d}$ as groundwater). The largest total withdrawals, and total surface-water withdrawals from land-based HUCs (756 and $748 \mathrm{Mgal} / \mathrm{d}$, respectively) were from the Lower Maumee (04100009) of Ohio (fig. 4); the largest total groundwater withdrawals ( $248 \mathrm{Mgal} / \mathrm{d})$ were from the St. Joseph (04050001) of Michigan and Indiana.

The intensity of withdrawals within the basin, measured as a function of area (including the portion of each Great Lake within the United States), was $0.17 \mathrm{Mgal} / \mathrm{d} / \mathrm{mi}^{2}$. Excluding the HUCs representing the five sparsely populated Great Lakes, the intensity of withdrawals within the entirety of land-based HUCs of the basin was $0.04 \mathrm{Mgal} / \mathrm{d} / \mathrm{mi}^{2}$. The intensity of the withdrawals within the land-based HUCs of the basin was substantially less than that within the basin as a whole because of the substantial volumes of water (about 24,000 Mgal/d) withdrawn directly from the Great Lakes.

The intensity of withdrawals within the five Great Lakes watersheds of the basin ranged from $0.03 \mathrm{Mgal} / \mathrm{d} / \mathrm{mi}^{2}$ in the Lake Superior watershed to $0.39 \mathrm{Mgal} / \mathrm{d} / \mathrm{mi}^{2}$ in the Lake Erie watershed. Excluding the HUCs representing the Great Lakes, the intensity of withdrawals within the Great Lakes watersheds ranged from $0.02 \mathrm{Mgal} / \mathrm{d} / \mathrm{mi}^{2}$ in the Lake Superior watershed to $0.11 \mathrm{Mgal} / \mathrm{d} / \mathrm{mi}^{2}$ in the Lake Erie watershed. The intensity of withdrawals within the eight states of the basin ranged from $0.04 \mathrm{Mgal} / \mathrm{d} / \mathrm{mi}^{2}$ in Pennsylvania to $1.09 \mathrm{Mgal} / \mathrm{d} / \mathrm{mi}^{2}$ in Illinois. Excluding the HUCs representing the Great Lakes, the intensity of withdrawals within the basin States ranged from $0.02 \mathrm{Mgal} / \mathrm{d} / \mathrm{mi}^{2}$ in Pennsylvania to $0.14 \mathrm{Mgal} / \mathrm{d} / \mathrm{mi}^{2}$ in Indiana.

The greatest intensity of withdrawals in the Lake Erie watershed, when both accounting for and excluding direct-lake withdrawals, is a function of the comparatively large in- and off-lake withdrawals in this watershed and the comparatively small areas representing both the watershed as a whole and the land-based part of the watershed. The greatest intensity of withdrawals in Illinois, when accounting for direct-lake withdrawals, is a function of the State's comparatively large direct withdrawals from Lake Michigan for public supply and its comparatively small area within the basin. The greatest intensity of withdrawals in Indiana, when excluding directlake withdrawals, is a function of the State's comparatively large groundwater and (or) surface-water withdrawals for public supply, domestic supply, industry, and irrigation and its comparatively small area within the basin.
Excluding the HUCs representing the five Great Lakes, where populations are sparse and direct-lake withdrawals are substantial, the greatest intensity of withdrawals by HUC was $1.23 \mathrm{Mgal} / \mathrm{d} / \mathrm{mi}^{2}$ in the Lower Fox (04030204) of Wisconsin, which includes the city of Green Bay (fig. 7A). Powerplant and industrial withdrawals account for the majority of use in that watershed. Examination of individual HUCs indicates that some smaller watersheds in the basin have a greater intensity of withdrawals than do some larger watersheds. Thermoelectric-power and (or) public-supply withdrawals, in large part, account for the more intensive water use in many of the comparatively smaller watersheds.

Gross per capita use within the basin, another indicator of intensity of use, was $1,320 \mathrm{gal} / \mathrm{d}$ in 2005 . The highest recorded gross per capita use, 1,510 gal/d, was in 1990 (Solley and others, 1993). High per capita use in the Great Lakes Basin generally corresponds to sparsely populated watersheds with large thermoelectric-power or other industrial-type water withdrawals. Excluding the HUCs representing the five sparsely populated Great Lakes where most basin withdrawals occur, gross per capita use within the entirety of the basin's landbased HUCs was $273 \mathrm{gal} / \mathrm{d}$.

Gross per capita use within the five Great Lakes watersheds of the basin ranged from $759 \mathrm{gal} / \mathrm{d}$ in the Lake Huron watershed to 2,330 gal/d in the Lake Superior watershed. Gross per capita use within the land-based HUCs of the Great Lakes watersheds ranged from $105 \mathrm{gal} / \mathrm{d}$ in those that compose the Lake Huron watershed to $749 \mathrm{gal} / \mathrm{d}$ in those that compose the Lake Superior watershed. Gross per capita use within the eight states of the basin ranged from $185 \mathrm{gal} / \mathrm{d}$ in Pennsylvania to 2,780 gal/d in Minnesota. The gross per capita use within the land-based HUCs of the basin states ranged from $12 \mathrm{gal} / \mathrm{d}$ in those of Illinois to $1,270 \mathrm{gal} / \mathrm{d}$ in those of Minnesota.

The greatest per capita use in the Lake Superior watershed, when both accounting for and excluding direct-lake withdrawals, is a function of the sparsely populated HUCs in this part of Minnesota and Michigan, and, in some locales, comparatively large withdrawals for mining. The low per capita use in Illinois, when excluding direct-lake withdrawals, is a function of the State's comparatively small volume of withdrawals in the densely populated basin area representing part of metropolitan Chicago. The water needs of this population are principally served by withdrawals from the adjacent HUC, which represents Lake Michigan.

Excluding the HUCs representing the five Great Lakes, where populations are sparse and direct-lake withdrawals are substantial, gross per capita use ranged from $6 \mathrm{gal} / \mathrm{d}$ in the Lake St. Clair (04090002) of Michigan to 3,030 gal/d in the Michigamme (04030107) of Michigan (fig. 7B). Most of the water used in the well-populated Lake St. Clair HUC near Detroit (0.62 million people) is supplied from outside the watershed by withdrawals from neighboring Great Lakes and (or) their connecting channels. The Michigamme HUC is in the sparsely populated Upper Peninsula of Michigan, and mining withdrawals account for the majority of use in that watershed. 


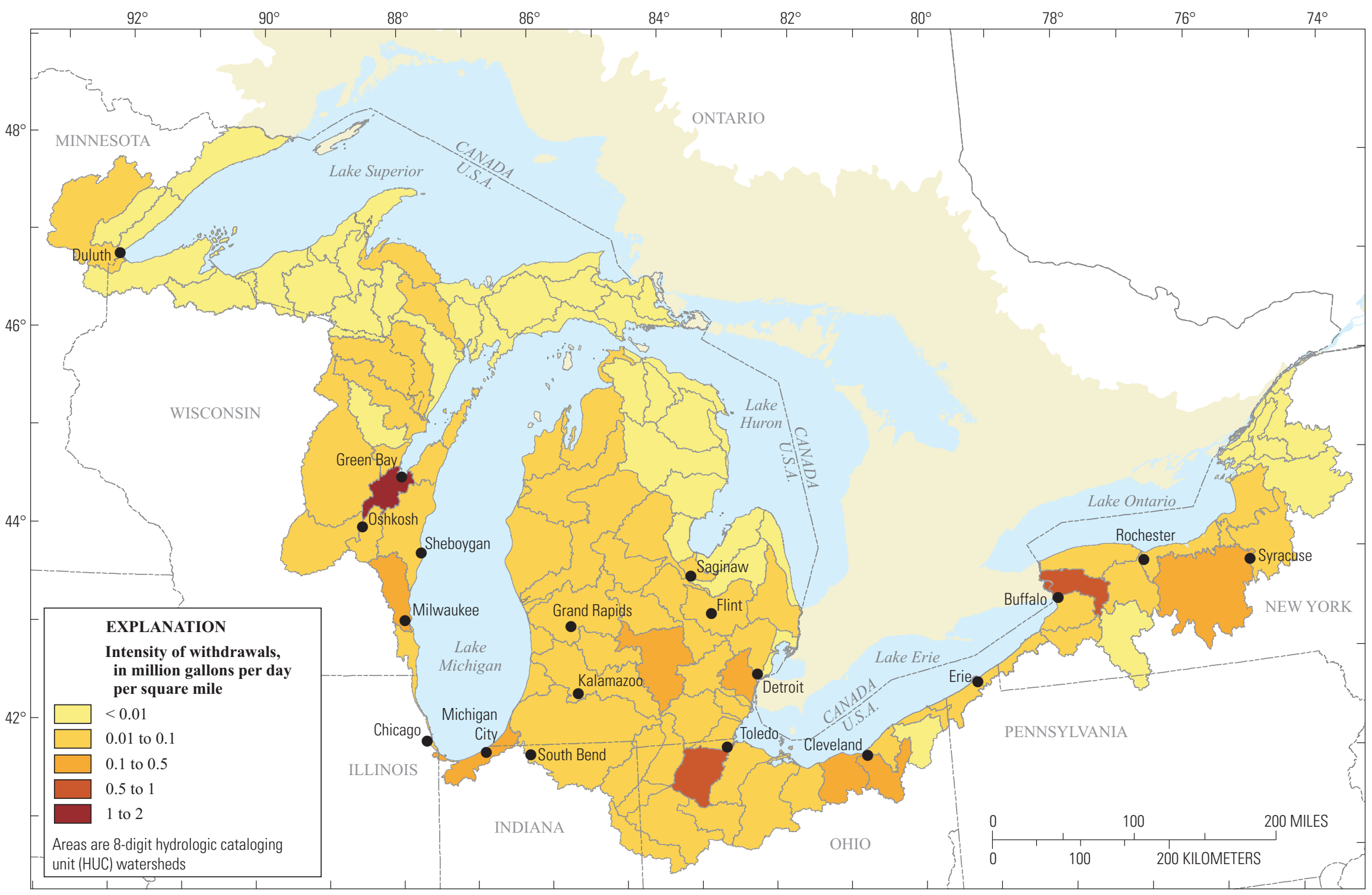

Figure 7. Intensity of water withdrawals in the Great Lakes Basin, 2005. $A$, Use as a function of land area. 


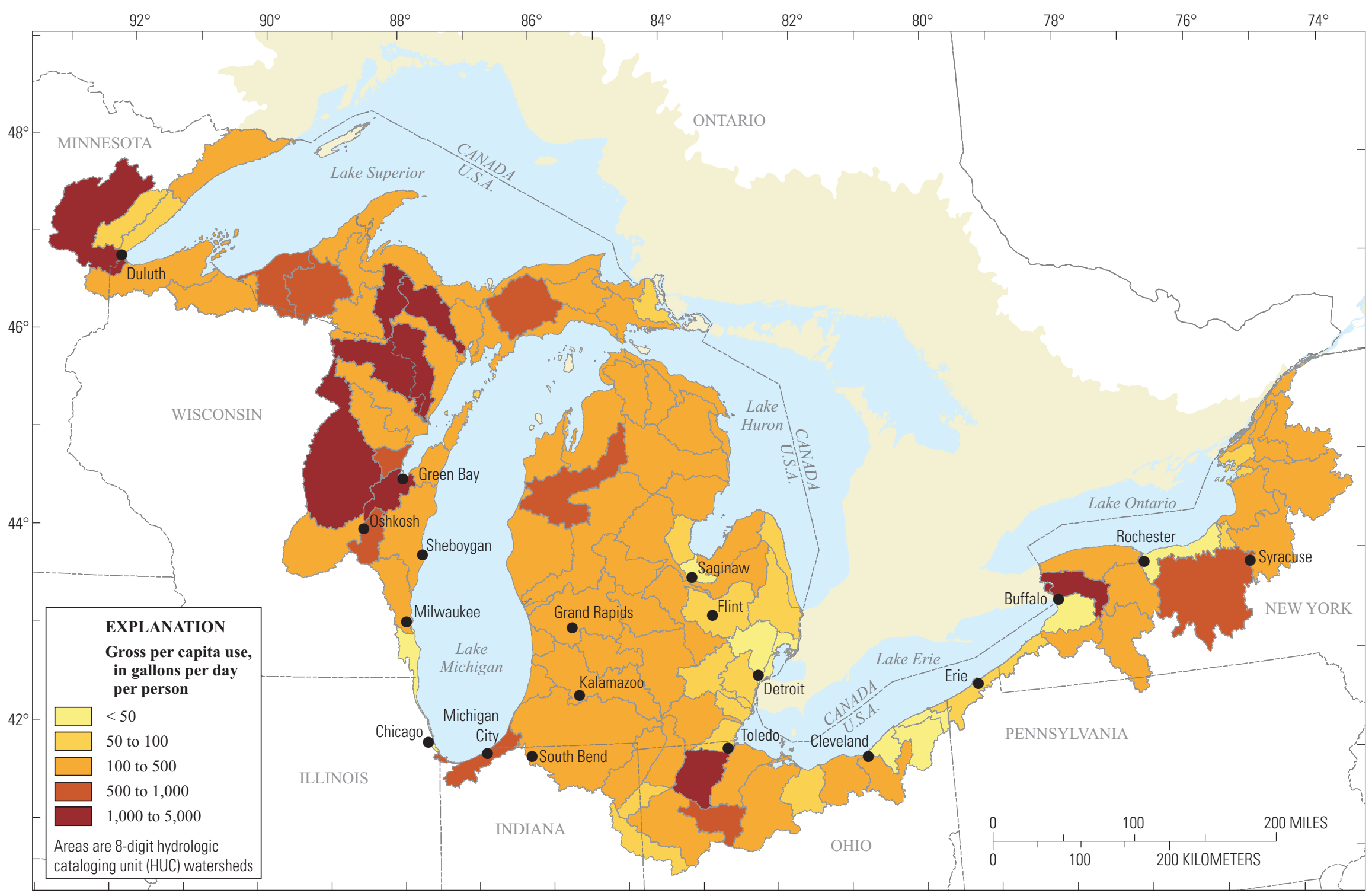

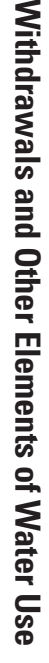

Figure 7. Intensity of water withdrawals in the Great Lakes Basin, 2005. B, Gross per capita use. 


\section{Public Supply}

Public supply refers to water withdrawn by public and private suppliers that furnish water to at least 25 people or have a minimum of 15 service connections year-round (U.S. Environmental Protection Agency, 2006b). Public-supply water may be delivered to users for domestic, commercial, industrial, irrigation, or thermoelectric-power purposes. Some public-supply water may be delivered to other public suppliers or used in the process of water and wastewater treatment. Public-supply water is used for such public uses as pools, parks, and public buildings; some of this water may be unaccounted for (losses) due to system leaks or nonmetered services such as firefighting or the flushing of utility water lines. All publicsupply withdrawals in the Great Lakes Basin are freshwater.
For 2005, public-use losses and water deliveries, other than domestic deliveries, were not mandatory accounting elements and thus were not compiled routinely by USGS Water Science Centers. As a result, only estimates for domestic deliveries by public supply are included in this report. These deliveries are included as an element of domestic use and presented and discussed in the report section "Domestic Supply." For this compilation and report, public-supply use refers to the collective withdrawals intended for all public purposes and for delivery to nonpublic users, including deliveries to domestic users.

Public-supply withdrawals and population served are summarized by Great Lakes watershed and by state in table 5 . Withdrawals and associated elements of water use are listed by individual HUC in appendix 1. For 2005, total withdrawal of surface water and groundwater in the Great Lakes Basin for

Table 5. Public-supply withdrawals for Great Lakes watersheds and states in the Great Lakes Basin, 2005.

[Figures may not sum to totals because of independent rounding]

\begin{tabular}{|c|c|c|c|c|c|c|}
\hline \multirow[b]{3}{*}{$\begin{array}{l}\text { Great Lakes } \\
\text { watershed }\end{array}$} & \multicolumn{3}{|c|}{ Population, in thousands } & \multicolumn{3}{|c|}{ Withdrawals, in million gallons per day } \\
\hline & \multirow[b]{2}{*}{ Total } & \multicolumn{2}{|c|}{ Served by public supply } & \multicolumn{2}{|c|}{ By source } & \multirow[b]{2}{*}{ Total } \\
\hline & & Population & $\begin{array}{l}\text { Population, } \\
\text { in percent }\end{array}$ & Surface water & Groundwater & \\
\hline Superior & 431.114 & 316.17 & 73 & 42.49 & 14.54 & 57.03 \\
\hline Michigan & $7,711.612$ & $5,414.34$ & 70 & $1,487.48$ & 295.40 & $1,782.88$ \\
\hline Huron & $1,617.285$ & 824.69 & 51 & 225.43 & 31.50 & 256.93 \\
\hline Erie & $10,800.648$ & $9,321.96$ & 86 & $1,293.21$ & 93.81 & $1,387.02$ \\
\hline Ontario & $2,349.828$ & $1,836.16$ & 78 & 304.46 & 22.84 & 327.30 \\
\hline \multirow[t]{3}{*}{ TOTAL } & $22,910.487$ & $17,713.32$ & 77 & $3,353.07$ & 458.09 & $3,811.16$ \\
\hline & \multicolumn{3}{|c|}{ Population, in thousands } & \multicolumn{3}{|c|}{ Withdrawals, in million gallons per day } \\
\hline & & \multicolumn{2}{|c|}{ Served by public supply } & \multicolumn{2}{|c|}{ By source } & \\
\hline State & Total & Population & $\begin{array}{l}\text { Population, } \\
\text { in percent }\end{array}$ & Surface water & Groundwater & Total \\
\hline Illinois & 667.500 & 666.66 & 100 & $1,023.70$ & 0.01 & $1,023.71$ \\
\hline Indiana & $1,369.794$ & $1,002.68$ & 73 & 110.08 & 60.74 & 170.82 \\
\hline Michigan & $10,120.859$ & $7,212.94$ & 71 & 882.61 & 260.15 & $1,142.76$ \\
\hline Minnesota & 215.094 & 169.11 & 79 & 34.30 & 5.99 & 40.29 \\
\hline New York & $3,551.985$ & $2,889.44$ & 81 & 490.64 & 25.95 & 516.59 \\
\hline Ohio & $4,014.374$ & $3,380.97$ & 84 & 533.44 & 33.56 & 567.00 \\
\hline Pennsylvania & 263.822 & 224.47 & 85 & 31.36 & 2.25 & 33.61 \\
\hline Wisconsin & $2,707.059$ & $2,167.05$ & 80 & 246.94 & 69.44 & 316.38 \\
\hline TOTAL & $22,910.487$ & $17,713.32$ & 77 & $3,353.07$ & 458.09 & $3,811.16$ \\
\hline
\end{tabular}


public supply was an estimated 3,810 Mgal/d. Public-supply withdrawals were 13 percent of total withdrawals in the basin for all categories of use and 46 percent of total withdrawals for all categories of use excluding thermoelectric power. About 17.7 million people in the basin or 77 percent of the total population of the basin depended on water from public suppliers. Eighty-eight percent of the water for public supply was withdrawn from surface sources, with about 76 percent directly from the Great Lakes or one of their connecting channels.

The Lake Michigan watershed accounted for the majority of withdrawals for public supply in the Great Lakes Basin (47 percent of public-supply withdrawals; $1,780 \mathrm{Mgal} / \mathrm{d}$ ), followed by the Lake Erie watershed (36 percent; 1,390 Mgal/d). The quantity of water withdrawn for public supply within each Great Lakes watershed strongly correlated $(r=0.90)$ with the population of the watersheds. The Lake Erie watershed accounted for 47 percent of the total population within the basin; the Lake Michigan watershed, 34 percent. Total withdrawals in the Lake Michigan watershed were notably greater than those in the Lake Erie watershed, despite a population that was about 29 percent less than that of the Lake Erie watershed. This discrepancy can be explained, in large part, by the transfer of large volumes of water outside the Lake Michigan watershed (and basin) to serve that population of about 6 million in the metropolitan region of Chicago, Ill. Consequently, per capita public-supply use is higher for the Lake Michigan watershed (329 gal/d) than for the other Great Lake watersheds (ranging from $149 \mathrm{gal} / \mathrm{d}$ for Lake Erie to $312 \mathrm{gal} / \mathrm{d}$ for Lake Huron).

The percentage of total population served by public supply ranged from 51 percent in the Lake Huron watershed to 86 percent in the Lake Erie watershed. The largest surface-water withdrawal for public supply, 1,490 Mgal/d (44 percent of public-supply surface-water withdrawals), was in the Lake Michigan watershed, as was the largest groundwater withdrawal, $295 \mathrm{Mgal} / \mathrm{d}$ (64 percent of public-supply groundwater withdrawals).

The quantity of water withdrawn for public supply within each Great Lakes State correlated less strongly $(r=0.67)$ with the state's basin population than that indicated for the Great Lakes watersheds. Michigan, the state with the largest population in the basin (10.1 million), accounted for 41 percent of the total population served by public supply and 30 percent of total public-supply withdrawals. However, despite representing less than 1 percent of the land-based area of the basin $\left(90 \mathrm{mi}^{2}\right)$ and only 3 percent of the basin population $(0.67 \mathrm{mil}-$ lion), the Illinois part of the basin accounted for 27 percent of the total public-supply withdrawals. About 6.7 million people in the Chicago, Ill., metropolitan area (in and outside the basin) are served by public water supplied from Lake Michigan, and this water is included in the State's withdrawal totals.

The distributions of total, surface-water, and groundwater withdrawals for public supply by HUC are shown in figure 8 . The largest total withdrawal (surface water plus groundwater), about 1,460 Mgal/d, was from Lake Michigan, principally to supply the large cities of Chicago $(1,020 \mathrm{Mgal} / \mathrm{d})$ and
Milwaukee. Withdrawals from the other Great Lakes included about $1,120 \mathrm{Mgal} / \mathrm{d}$ from Lake Erie $(0.01 \mathrm{Mgal} / \mathrm{d}$ were reported as groundwater withdrawals), principally to supply Detroit and Cleveland; $225 \mathrm{Mgal} / \mathrm{d}$, Lake Huron; $70.1 \mathrm{Mgal} / \mathrm{d}$, Lake Ontario; and $37.3 \mathrm{Mgal} / \mathrm{d}$, Lake Superior. The largest total withdrawal, $125 \mathrm{Mgal} / \mathrm{d}$, and surface-water withdrawal, $117 \mathrm{Mgal} / \mathrm{d}$, from a land-based HUC were in the Seneca (04140201) of New York; and the largest total groundwater withdrawal, 73.8 Mgal/d, was in the St. Joseph (04050001) of Indiana and Michigan, followed by $56.0 \mathrm{Mgal} / \mathrm{d}$ in the Upper Grand (04050004) of Michigan. The largest public-water supplied populations are in densely populated urban HUCs adjacent to the Great Lakes; these include the Detroit (04090004) (2.1 million), followed by the Pike-Root (04040002), Milwaukee (04040003), Clinton (04090003), and Cuyahoga (04110002) (each about 0.9 million) (figs. 4, 3, 2).

\section{Self-Supplied Domestic}

Domestic water use is that used for indoor and outdoor household purposes. Common indoor uses include drinking, preparing food, bathing, washing clothes and dishes, and flushing toilets. Major outdoor uses include watering lawns and gardens, filling swimming pools, and washing cars. Water for domestic use may be self-supplied or delivered from a public supplier. In this compilation and report, the category of domestic use refers to both self-supplied withdrawals and domestic deliveries from public supply. For self-supplied domestic water, the source usually is a well. All self-supplied domestic withdrawals are considered freshwater. Self-supplied domestic population was defined as the difference between the total population for 2005 , as determined by the U.S. Census Bureau, and the population served by public suppliers.

Self-supplied domestic withdrawals, domestic population served by public supply, and domestic deliveries from public supply were estimated and reported for 2005. Estimates for each of these elements of domestic use are included and discussed in this report. Domestic supply consumptive use was not a mandatory accounting element for 2005 , and estimates in this category were compiled only by the USGS Ohio Water Science Center (provisional estimates for basin HUCs in Ohio can be found at http://water.usgs.gov/watuse/). On the basis of the domestic-withdrawal estimates and data available from other sources, consumptive use is estimated for the basin and discussed briefly in the report section "Consumptive Use."

Self-supplied domestic withdrawals and population are summarized by Great Lakes watershed and by state in table 6 . Withdrawals and associated elements of water use are listed by individual HUC in appendix 1. For 2005, total self-supplied domestic withdrawals in the Great Lakes Basin were an estimated $412 \mathrm{Mgal} / \mathrm{d}$. Self-supplied domestic withdrawals were about 1 percent of total withdrawals in the basin and 5 percent of total withdrawals for all categories of use excluding thermoelectric power. Domestic public-supply deliveries totaled $1,410 \mathrm{Mgal} / \mathrm{d}$. 

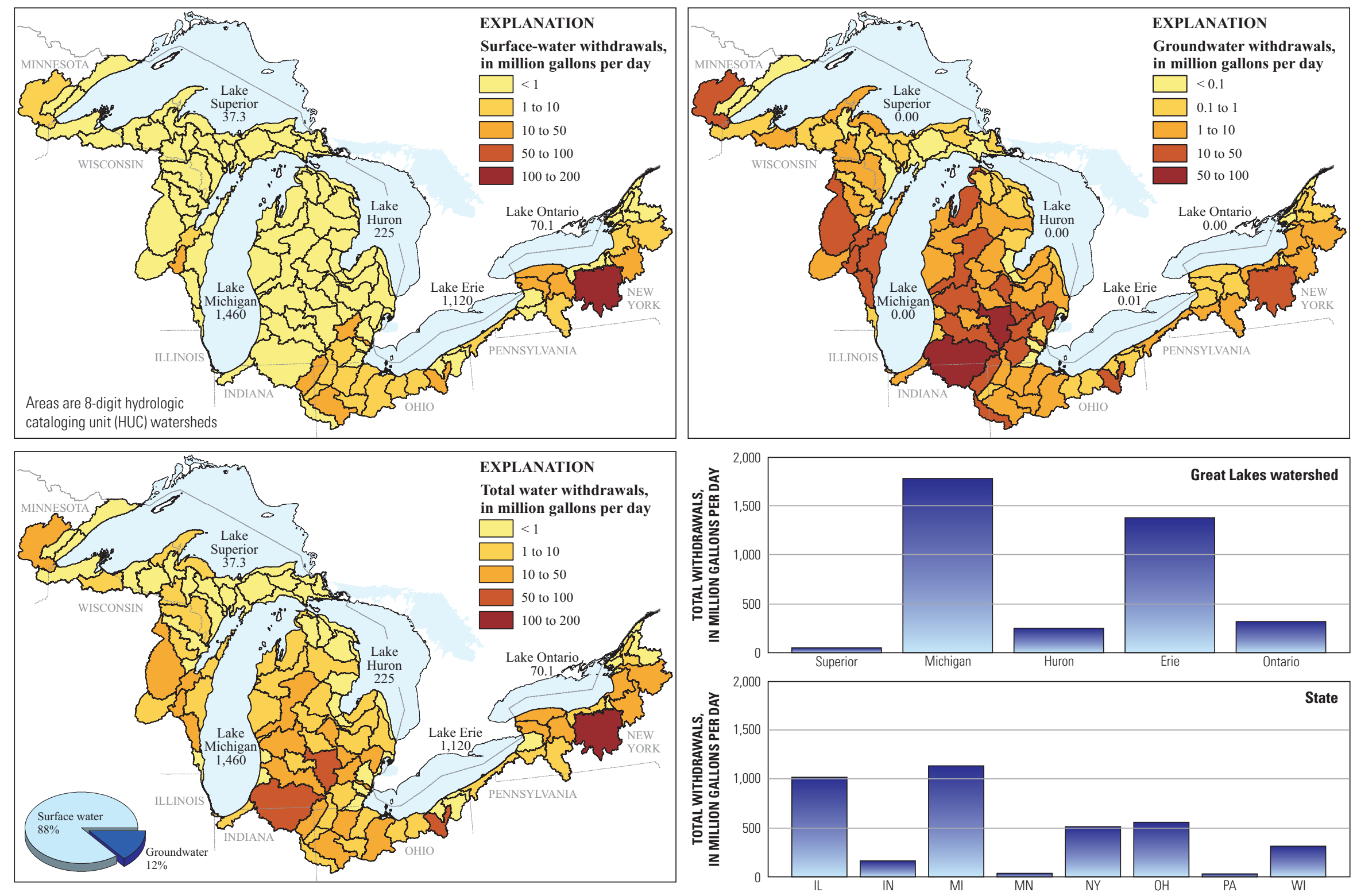

Figure 8. Public-supply withdrawals by source, watershed, and state in the Great Lakes Basin, 2005. 
Table 6. Self-supplied domestic withdrawals for Great Lakes watersheds and states in the Great Lakes Basin, 2005.

[Figures may not sum to totals because of independent rounding]

\begin{tabular}{|c|c|c|c|c|c|c|c|}
\hline \multirow[b]{3}{*}{$\begin{array}{c}\text { Great Lakes } \\
\text { watershed }\end{array}$} & \multicolumn{4}{|c|}{ Population, in thousands } & \multicolumn{3}{|c|}{ Withdrawals, in million gallons per day } \\
\hline & \multirow[b]{2}{*}{ Total } & \multirow[b]{2}{*}{$\begin{array}{c}\text { Served by } \\
\text { public supply }\end{array}$} & \multicolumn{2}{|c|}{ Self-supplied domestic } & \multicolumn{2}{|c|}{ By source } & \multirow[b]{2}{*}{ Total } \\
\hline & & & Population & $\begin{array}{l}\text { Population, } \\
\text { in percent }\end{array}$ & Surface water & Groundwater & \\
\hline Superior & 431.114 & 316.17 & 114.95 & 27 & 0.00 & 7.81 & 7.81 \\
\hline Michigan & $7,711.612$ & $5,414.34$ & $2,297.30$ & 30 & .00 & 178.52 & 178.52 \\
\hline Huron & $1,617.285$ & 824.69 & 792.59 & 49 & .00 & 68.41 & 68.41 \\
\hline Erie & $10,800.648$ & $9,321.96$ & $1,478.65$ & 14 & .96 & 116.49 & 117.45 \\
\hline Ontario & $2,349.828$ & $1,836.16$ & 513.64 & 22 & .00 & 40.20 & 40.20 \\
\hline \multirow[t]{3}{*}{ TOTAL } & $22,910.487$ & $17,713.32$ & $5,197.126$ & 23 & .96 & 411.43 & 412.39 \\
\hline & \multicolumn{4}{|c|}{ Population, in thousands } & \multicolumn{3}{|c|}{ Withdrawals, in million gallons per day } \\
\hline & & & \multicolumn{2}{|c|}{ Self-supplied domestic } & \multicolumn{2}{|c|}{ By source } & \\
\hline State & Total & $\begin{array}{c}\text { Served by } \\
\text { public supply }\end{array}$ & Population & $\begin{array}{l}\text { Population, } \\
\text { in percent }\end{array}$ & Surface water & Groundwater & Total \\
\hline Illinois & 667.500 & 666.66 & 0.84 & 0 & 0.00 & 0.08 & 0.08 \\
\hline Indiana & $1,369.794$ & $1,002.68$ & 367.13 & 27 & .00 & 27.90 & 27.90 \\
\hline Michigan & $10,120.859$ & $7,212.94$ & $2,907.89$ & 29 & .00 & 250.95 & 250.95 \\
\hline Minnesota & 215.094 & 169.11 & 45.99 & 21 & .00 & 3.22 & 3.22 \\
\hline New York & $3,551.985$ & $2,889.44$ & 662.51 & 19 & .00 & 51.55 & 51.55 \\
\hline Ohio & $4,014.374$ & $3,380.97$ & 633.39 & 16 & .96 & 46.90 & 47.86 \\
\hline Pennsylvania & 263.822 & 224.47 & 39.35 & 15 & .00 & 2.36 & 2.36 \\
\hline Wisconsin & $2,707.059$ & $2,167.05$ & 540.03 & 20 & .00 & 28.47 & 28.47 \\
\hline TOTAL & $22,910.487$ & $17,713.32$ & $5,197.126$ & 23 & .96 & 411.43 & 412.39 \\
\hline
\end{tabular}

About 5.20 million people in the basin were selfsupplied, and groundwater was essentially the single source of that water (greater than 99.7 percent of withdrawals). All reported surface-water withdrawals occurred in 16 Ohio watersheds (appendix $1 B$ ). The self-supplied domestic population was 23 percent of the total population of the basin.

The Lake Michigan watershed accounted for the largest proportion of self-supplied domestic withdrawals (43 percent of domestic withdrawals; $179 \mathrm{Mgal} / \mathrm{d}$ ), followed by the Lake Erie watershed (28 percent; $117 \mathrm{Mgal} / \mathrm{d}$ ). Great Lakes watersheds and states with the largest populations generally withdrew the largest quantities of water $(\mathrm{r}=0.81$ and $\mathrm{r}=0.97$, respectively). The Lake Michigan watershed accounted for 34 percent of the total population of the basin and 44 percent of the self-supplied domestic population. A larger rural population in the Lake Michigan watershed likely accounts for the greater volume of self-supplied domestic withdrawals in that watershed than the more populous Lake Erie watershed (7.7 and 10.8 million total residents, respectively). Michigan, the state with the largest population in the basin, accounted for 56 percent of the total self-supplied population and 61 percent of self-supplied domestic withdrawals. The percentage of total population that was self-supplied ranged from less than 1 percent in Illinois to about 28 percent in Indiana and Michigan.

The distributions of total self-supplied domestic withdrawals, self-supplied domestic population, and domestic public-supply deliveries by HUC are shown in figure 9. The largest total withdrawal and groundwater withdrawal, $30.6 \mathrm{Mgal} / \mathrm{d}$, was in the St. Joseph (04050001) of Indiana and Michigan. This watershed also had the largest self-supplied population, at 0.38 million. The largest surface-water withdrawal, $0.19 \mathrm{Mgal} / \mathrm{d}$, was in the Cuyahoga (04110002) 

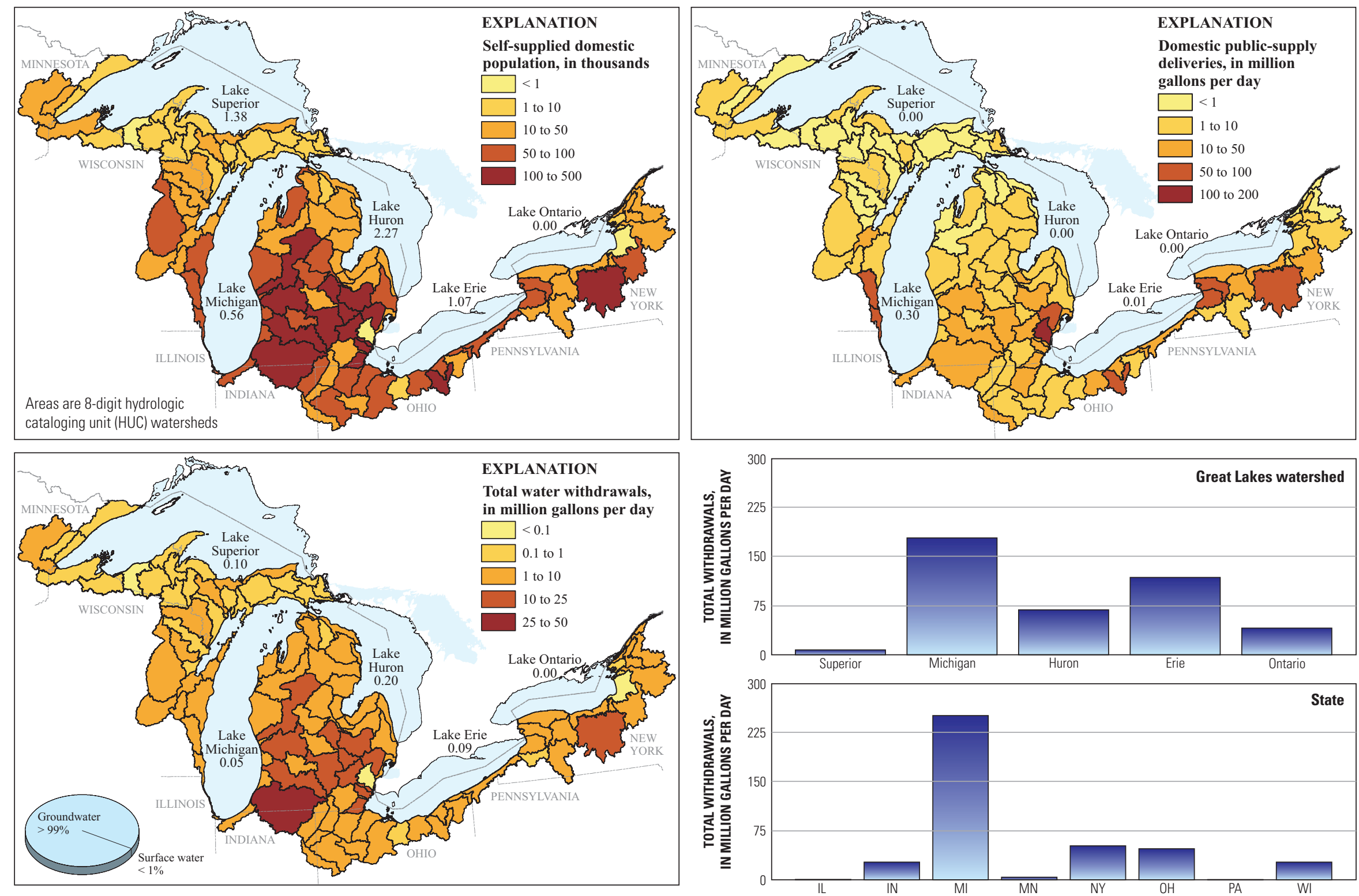

Figure 9. Self-supplied domestic population and public-supply deliveries by watershed and total self-supplied domestic withdrawals by source, watershed, and state in the Great Lakes Basin, 2005. 
of Ohio. Within state areas, about 46 percent of domestic withdrawals occurred within 13 HUCs (10 in Michigan, and 1 each in Indiana, New York, and Ohio); withdrawals within these HUCs ranged from about 10 to $23 \mathrm{Mgal} / \mathrm{d}$. The largest domestic public-supply deliveries, $171 \mathrm{Mgal} / \mathrm{d}$, were in the Detroit (04090004), serving the large population of metropolitan Detroit.

\section{Thermoelectric Power}

Water for thermoelectric power is used in the process of generating electricity with steam-driven turbine generators. In this process, some water is converted to steam to drive the generators; most is continuously circulated for cooling. Beginning with the 2000 report, thermoelectric-power water withdrawals were compiled by cooling-system type; coolingsystem type is the primary determinant for the amount of consumptive use relative to withdrawals. Once-through cooling refers to a cooling system in which water is withdrawn from a source, typically a surface-water body, circulated through heat exchangers to condense steam to water, and then returned to the source. Closed-loop cooling refers to a cooling system in which water is withdrawn from a source, circulated through heat exchangers, cooled, and then recirculated. Cooling can be achieved by routing the water through cooling towers or manmade or natural ponds or lakes (referred to as "cooling ponds"), or by other means. Cooling ponds generally require a shallow reservoir with a large surface area to effectively dissipate the heat. Subsequent water withdrawals for a closed-loop system are used to replace water lost primarily to evaporation, as well as to blowdown, drift, and leakage. Closed-loop cooling results in larger consumptive use relative to withdrawals than does open-loop cooling (Solley and others, 1998). Individual plants may rely on different cooling systems at different times or during different seasons. Within the Great Lakes Basin, only freshwater is used for thermoelectric-power cooling systems and other aspects of power generation.

For 2005, public-supply deliveries to thermoelectric powerplants and consumptive use were not mandatory accounting elements, and estimates in these categories were compiled only by the USGS Ohio Water Science Center (provisional estimates for basin HUCs in Ohio can be found at http://water.usgs.gov/watuse/). Only self-supplied withdrawals are considered in this accounting and report of thermoelectricpower withdrawals. On the basis of the thermoelectric-power withdrawal estimates and data available from other sources, consumptive use is estimated for the basin and discussed briefly in this report section and in somewhat greater detail later in the report, in the "Consumptive Use" section.

Thermoelectric-power withdrawals (total and by coolingsystem type) and net power generation are summarized by Great Lakes watershed and by state in table 7. Withdrawals and associated elements of water use are listed by individual HUC in appendix 1. For 2005, total withdrawals in the Great Lakes Basin for thermoelectric-power generation were an estimated 21,900 Mgal/d. Surface water was the source for more than 99 percent of the thermoelectric-power withdrawals. About 19,100 Mgal/d was withdrawn directly from the Great Lakes or their connecting channels. Thermoelectricpower withdrawals accounted for 72 percent of total water withdrawals in the basin and 76 percent of total surface-water withdrawals. The high percentage of total water withdrawal represented by thermoelectric-power use is characteristic in eastern states, where the power-production infrastructure was established to take advantage of the extensive water supply of the Great Lakes and major rivers and to satisfy the electricalpower demands of nearby large urban and industrial centers. The majority of these centers, including about 80 percent of the basin population (U.S. Department of Commerce, 2005), are within about $50 \mathrm{mi}$ of one of the Great Lakes. This population distribution is shown variously in figures 2 and 3 by the population distributions and land-cover/land-use patterns in the basin.

The distributions of total, total surface-water, and total groundwater withdrawals by HUC are shown in figure 10. The largest total withdrawal, about 9,450 Mgal/d, was from Lake Michigan. Withdrawals from other Great Lakes included about 6,440 Mgal/d from Lake Erie; 2,030 Mgal/d, Lake Ontario; $810 \mathrm{Mgal} / \mathrm{d}$, Lake Huron; and $321 \mathrm{Mgal} / \mathrm{d}$, Lake Superior. An estimated 83 percent of the withdrawals for thermoelectricpower generation occurred in two Great Lakes watersheds, about 47 percent $(10,300 \mathrm{Mgal} / \mathrm{d})$ in the Lake Michigan watershed and 36 percent $(7,930 \mathrm{Mgal} / \mathrm{d})$ in the Lake Erie watershed. For states in the basin, the largest water withdrawals for thermoelectric-power generation were in Michigan $(9,150 \mathrm{Mgal} / \mathrm{d})$, followed by Wisconsin (5,230 Mgal/d). Withdrawals from surface waters other than one of the Great Lakes were limited to powerplants located in 16 HUCs. The largest total withdrawal and surface-water withdrawal from a land-based HUC, at $731 \mathrm{Mgal} / \mathrm{d}$, were in the Lower Maumee (04100009) of Ohio. The largest groundwater withdrawal, $1.26 \mathrm{Mgal} / \mathrm{d}$, was in the Michigan area of the St. Joseph (04050001), followed by $1.02 \mathrm{Mgal} / \mathrm{d}$ in the Manitowoc (04030101) of Wisconsin. Groundwater withdrawals ranging from 0.01 to $0.89 \mathrm{Mgal} / \mathrm{d}$ were reported in only 10 other HUCs in the basin.

Plants equipped with closed-loop cooling systems accounted for less than 1 percent of water withdrawals for thermoelectric-power generation. The predominance of once-through cooling systems in the basin is driven by the abundance of water supply relative to other parts of the United States, where closed-loop cooling systems predominate (Hutson and others, 2004). Once-through cooling systems also generally are common to older (pre-1970s) plants typically constructed before thermal requirements for return water became more restrictive (Hutson, 2007). Many older plants likely are particular to the populated northern Midwest and Northeastern States, having been built before the 1970s, when population and industrial activity in the region were at their peak (Great Lakes Information Network, 2008). 

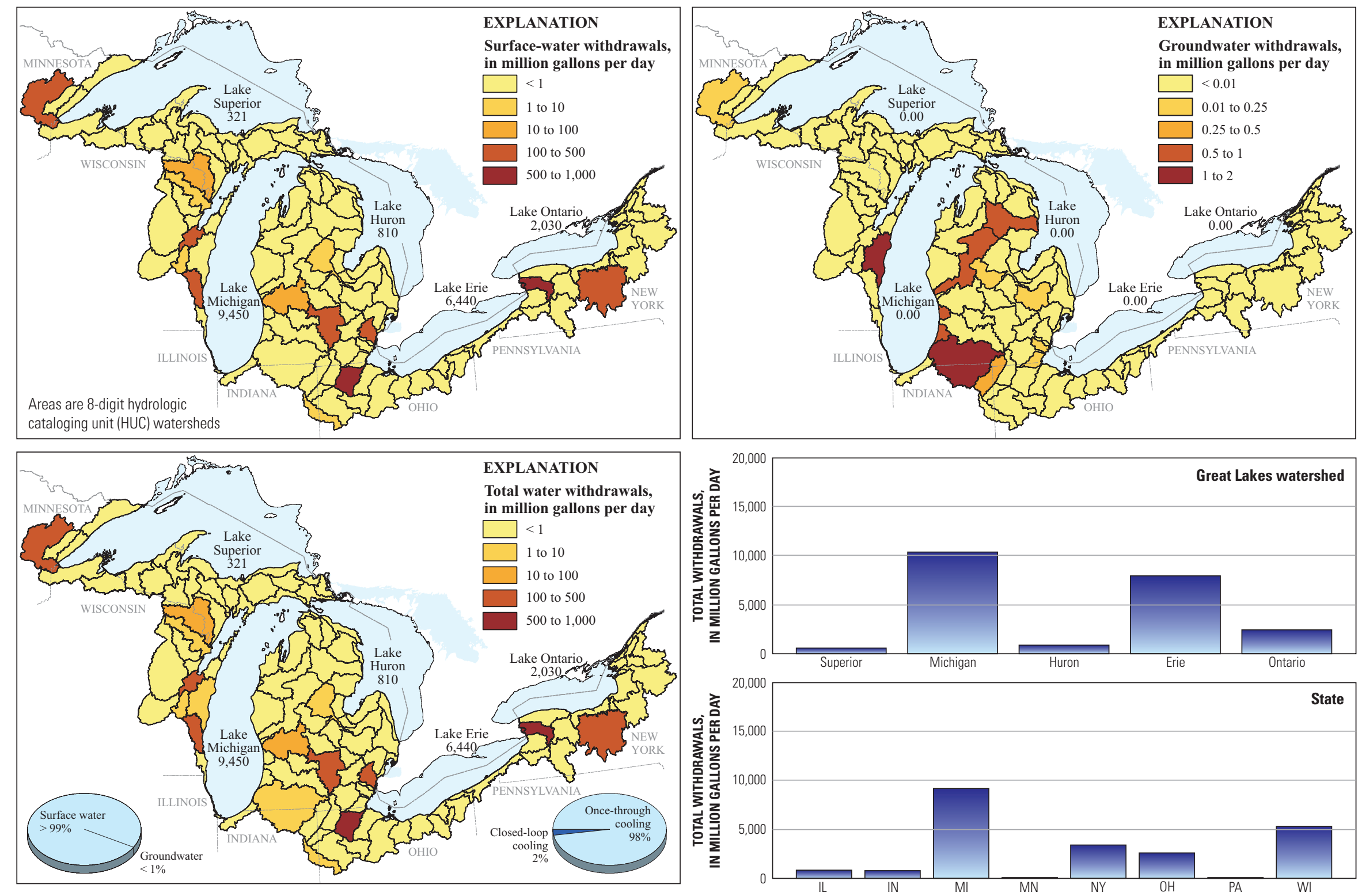

Figure 10. Thermoelectric-power withdrawals by source, watershed, and state in the Great Lakes Basin, 2005. 
Table 7. Thermoelectric-power withdrawals for Great Lakes watersheds and states in the Great Lakes Basin, 2005.

[Figures may not sum to totals because of independent rounding]

\begin{tabular}{|c|c|c|c|c|c|c|}
\hline \multirow{4}{*}{$\begin{array}{l}\text { Great Lakes } \\
\text { watershed }\end{array}$} & \multicolumn{6}{|c|}{ Withdrawals, in million gallons per day } \\
\hline & \multicolumn{3}{|c|}{ By source and type } & \multirow{2}{*}{\multicolumn{3}{|c|}{ Total }} \\
\hline & \multirow{2}{*}{$\frac{\text { Surface water }}{\text { Fresh }}$} & \multicolumn{2}{|c|}{ Groundwater } & & & \\
\hline & & Fresh & Total & Fresh & Saline & Total \\
\hline Superior & 511.36 & 0.11 & 511.47 & 511.47 & 0.00 & 511.47 \\
\hline Michigan & $10,334.52$ & 3.79 & $10,338.31$ & $10,338.31$ & .00 & $10,338.31$ \\
\hline Huron & 814.42 & 1.22 & 815.64 & 815.64 & .00 & 815.64 \\
\hline Erie & $7,933.30$ & .36 & $7,933.66$ & $7,933.66$ & .00 & $7,933.66$ \\
\hline Ontario & $2,340.90$ & .00 & $2,340.90$ & $2,340.90$ & .00 & $2,340.90$ \\
\hline \multirow[t]{4}{*}{ TOTAL } & $21,934.50$ & 5.48 & $21,939.98$ & $21,939.98$ & .00 & $21,939.98$ \\
\hline & \multicolumn{6}{|c|}{ Withdrawals, in million gallons per day } \\
\hline & \multicolumn{3}{|c|}{ By source and type } & & & \\
\hline & Surface water & \multicolumn{2}{|c|}{ Groundwater } & \multicolumn{3}{|c|}{ Total } \\
\hline State & Fresh & Fresh & Total & Fresh & Saline & Total \\
\hline Illinois & 758.32 & 0.00 & 758.32 & 758.32 & 0.00 & 758.32 \\
\hline Indiana & 727.86 & .27 & 728.13 & 728.13 & .00 & 728.13 \\
\hline Michigan & $9,144.84$ & 4.07 & $9,148.91$ & $9,148.91$ & .00 & $9,148.91$ \\
\hline Minnesota & 190.23 & .11 & 190.34 & 190.34 & .00 & 190.34 \\
\hline New York & $3,362.80$ & .00 & $3,362.80$ & $3,362.80$ & .00 & $3,362.80$ \\
\hline Ohio & $2,517.99$ & .00 & $2,517.99$ & $2,517.99$ & .00 & $2,517.99$ \\
\hline Pennsylvania & .00 & .00 & .00 & .00 & .00 & .00 \\
\hline Wisconsin & $5,232.46$ & 1.03 & $5,233.49$ & $5,233.49$ & .00 & $5,233.49$ \\
\hline TOTAL & $21,934.50$ & 5.48 & $21,939.98$ & $21,939.98$ & .00 & $21,939.98$ \\
\hline
\end{tabular}

With the predominance of thermoelectric powerplants in the basin using once-through cooling systems, reuse potential of water in the basin is high. Given the typically low consumptive use of water associated with these plants, about 1 to 3 percent (Solley and others, 1998; Marilee Horn, U.S. Geological Survey, written commun., 2009), the majority of the large volumes of water withdrawn by these plants are returned to the surface-water sources.

Net (power) generation is the amount of gross generation less the electrical energy consumed at the generating station for station service (U.S. Department of Energy, Energy Information Administration, 2007). For 2005, about 234,200 GWh of net power was generated in the Great Lakes Basin. Net power generation in basin states generally correlated with total water withdrawals for thermoelectric-power generation and population ( $\mathrm{r}=0.97$ and 0.98 , respectively). An estimated $116,700 \mathrm{GWh}$ was generated in Michigan, representing 50 percent of the generation in the basin; power generation also was comparatively high in Ohio, Wisconsin, and New York (from 11 to 18 percent of generation in the basin). An estimated 87 percent of the power generation was at thermoelectric powerplants withdrawing water for cooling directly from one of the Great Lakes or a connecting channel. 


\section{Industrial and Commercial}

Industrial water use includes water used for such purposes as fabricating, processing, washing, diluting, cooling, or transporting a product; incorporating water into a product; or maintaining sanitation within the manufacturing facility. Some industries that use large amounts of water produce such commodities as food, paper, chemicals, refined petroleum, or primary metals. Water for industrial use may be delivered from a public supplier or be self-supplied. Only self-supplied withdrawals are considered in this accounting and report of industrial use. Withdrawals were reported as freshwater or saline water, because the extraction of saline water has been indicated in past accountings of industrial withdrawals in the basin.
For 2005, public-supply deliveries to industrial users and consumptive were not mandatory accounting elements, and estimates in this category were compiled only by the USGS Ohio Water Science Center (provisional estimates for basin HUCs in Ohio can be found at http://water.usgs.gov/watuse/). On the basis of the industrial-withdrawal estimates and data available from other sources, consumptive use is estimated for the basin and discussed briefly in the report section "Consumptive Use."

Industrial withdrawals are summarized by Great Lakes watershed and by state in table 8 . Withdrawals and associated elements of water use are listed by individual HUC in appendix 1. For 2005, total withdrawals in the Great Lakes Basin for industrial use were an estimated 2,930 Mgal/d. All the withdrawals were reported as freshwater. Industrial

Table 8. Industrial withdrawals for Great Lakes watersheds and states in the Great Lakes Basin, 2005.

[Figures may not sum to totals because of independent rounding]

Withdrawals, in million gallons per day

\begin{tabular}{|c|c|c|c|c|c|c|c|c|c|}
\hline \multirow{3}{*}{$\begin{array}{l}\text { Great Lakes } \\
\text { watershed }\end{array}$} & \multicolumn{6}{|c|}{ By source and type } & & & \\
\hline & \multicolumn{3}{|c|}{ Surface water } & \multicolumn{3}{|c|}{ Groundwater } & \multicolumn{3}{|c|}{ Total } \\
\hline & Fresh & Saline & Total & Fresh & Saline & Total & Fresh & Saline & Total \\
\hline Superior & 22.62 & 0.00 & 22.62 & 0.54 & 0.00 & 0.54 & 23.16 & 0.00 & 23.16 \\
\hline Michigan & $2,012.77$ & .00 & $2,012.77$ & 104.22 & .00 & 104.22 & $2,116.99$ & .00 & $2,116.99$ \\
\hline Huron & 32.73 & .00 & 32.73 & 1.98 & .00 & 1.98 & 34.71 & .00 & 34.71 \\
\hline Erie & 656.91 & .00 & 656.91 & 35.00 & .00 & 35.00 & 691.91 & .00 & 691.91 \\
\hline Ontario & 54.73 & .00 & 54.73 & 8.37 & .00 & 8.37 & 63.10 & .00 & 63.10 \\
\hline TOTAL & $2,779.76$ & .00 & $2,779.76$ & 150.11 & .00 & 150.11 & $2,929.87$ & .00 & $2,929.87$ \\
\hline
\end{tabular}

Withdrawals, in million gallons per day

\begin{tabular}{|c|c|c|c|c|c|c|c|c|c|}
\hline \multirow[b]{3}{*}{ State } & \multicolumn{6}{|c|}{ By source and type } & & & \\
\hline & \multicolumn{3}{|c|}{ Surface water } & \multicolumn{3}{|c|}{ Groundwater } & \multicolumn{3}{|c|}{ Total } \\
\hline & Fresh & Saline & Total & Fresh & Saline & Total & Fresh & Saline & Total \\
\hline Illinois & 18.52 & 0.00 & 18.52 & 0.00 & 0.00 & 0.00 & 18.52 & 0.00 & 18.52 \\
\hline Indiana & $1,613.51$ & .00 & $1,613.51$ & 11.08 & .00 & 11.08 & $1,624.59$ & .00 & $1,624.59$ \\
\hline Michigan & 539.66 & .00 & 539.66 & 89.10 & .00 & 89.10 & 628.76 & .00 & 628.76 \\
\hline Minnesota & 7.76 & .00 & 7.76 & .01 & .00 & .01 & 7.77 & .00 & 7.77 \\
\hline New York & 84.14 & .00 & 84.14 & 10.35 & .00 & 10.35 & 94.49 & .00 & 94.49 \\
\hline Ohio & 320.71 & .00 & 320.71 & 14.83 & .00 & 14.83 & 335.54 & .00 & 335.54 \\
\hline Pennsylvania & 5.21 & .00 & 5.21 & .02 & .00 & .02 & 5.23 & .00 & 5.23 \\
\hline Wisconsin & 190.25 & .00 & 190.25 & 24.72 & .00 & 24.72 & 214.97 & .00 & 214.97 \\
\hline TOTAL & $2,779.76$ & .00 & $2,779.76$ & 150.11 & 0.00 & 150.11 & $2,929.87$ & .00 & $2,929.87$ \\
\hline
\end{tabular}


withdrawals were 10 percent of total withdrawals in the basin and 35 percent of total withdrawals for all categories of use excluding thermoelectric power. Ninety-five percent of the water for self-supplied industrial use was withdrawn from surface sources, with about 60 percent directly from the Great Lakes or one of their connecting channels.

The Lake Michigan watershed accounted for the majority of total withdrawals for industrial use (72 percent; 2,120 Mgal/d), as well as the majority of surface-water withdrawals (72 percent; $2,010 \mathrm{Mgal} / \mathrm{d}$ ) and groundwater withdrawals (69 percent; $104 \mathrm{Mgal} / \mathrm{d}$ ) for such use. The Lake Erie watershed also accounted for a comparatively large quantity of surface-water and groundwater withdrawals (24 and 23 percent, respectively).

For states in the basin, Indiana accounted for 55 percent of total industrial withdrawals $(1,620 \mathrm{Mgal} / \mathrm{d})$, followed by Michigan (19 percent; $629 \mathrm{Mgal} / \mathrm{d}$ ). The largest surface-water withdrawals were in Indiana $(1,610 \mathrm{Mgal} / \mathrm{d} ; 58$ percent); the largest groundwater withdrawals in Michigan (89.1 Mgal/d; 59 percent).

The distributions of total, total surface-water, and total groundwater withdrawals for industrial use by HUC are shown in figure 11. The largest total withdrawal, about $1,430 \mathrm{Mgal} / \mathrm{d}$, was from Lake Michigan. About $303 \mathrm{Mgal} / \mathrm{d}$ was withdrawn from Lake Erie. Estimated withdrawals from Lakes Ontario, Superior, and Huron ranged from 0.22 to $19.6 \mathrm{Mgal} / \mathrm{d}$, respectively. The largest total withdrawal and surface-water withdrawal from land-based HUCs, 310 and $308 \mathrm{Mgal} / \mathrm{d}$, respectively, were in the Little Calumet-Galien (04040001) of Indiana and Michigan; 98 percent of the surface-water withdrawal occurred within Indiana. Total (and surface-water) withdrawals in other HUCs were less than about $120 \mathrm{Mgal} / \mathrm{d}$, but more typically were less than about $60 \mathrm{Mgal} / \mathrm{d}$. The largest groundwater withdrawal, $35.6 \mathrm{Mgal} / \mathrm{d}$, was in the Kalamazoo (04050003) of Michigan; withdrawals in six other HUCs in the Lake Michigan and Lake Erie watersheds ranged from about 5 to $15 \mathrm{Mgal} / \mathrm{d}$.

In compilations by other agencies, commercial water use sometimes is included in the consideration of industrial water use. Commercial use includes the use of water by facilities such as motels, restaurants, office buildings, retail outlets, and residential institutions, among others. Water may be selfsupplied or obtained from (delivered by) a public supply. For 2005, commercial use was not a mandatory accounting category; thus, commercial withdrawals were compiled by only some of the USGS Water Science Centers in the basin. These estimates for selected basin HUCs are included in appendix 1. Commercial deliveries and consumptive use also were not mandatory accounting elements for 2005 and estimates in these categories were compiled only by the USGS Ohio Water Science Center (provisional estimates for basin HUCs in Ohio can be found at http://water.usgs.gov/watuse/). On the basis of the available commercial-withdrawal estimates and data available from other sources, consumptive use is estimated for the basin and discussed briefly in the report section "Consumptive Use."
Although not routinely compiled by USGS Water Science Centers for 2005, commercial withdrawals in the Great Lakes Basin are briefly considered here to address their periodic consideration with industrial use by others and to better account for the entirety of basin water use. It is expected that selfsupplied commercial withdrawals represent only a small fraction of total withdrawals in the basin. Since 1985, estimated withdrawals have not exceeded 0.46 percent of total withdrawals, as reported for 1995 (Solley and others, 1998). For those states furnishing estimates of commercial use in the basin for 2005 (all but Michigan, New York, and Pennsylvania), total withdrawals were $44.3 \mathrm{Mgal} / \mathrm{d}$. The largest use by HUC was in the Indiana area of the St. Joseph (04050001), at 27.1 Mgal/d, followed by the Sandusky (04100011) of Ohio, at $3.0 \mathrm{Mgal} / \mathrm{d}$. Use in the St. Joseph watershed was about equally distributed between surface-water and groundwater withdrawals. Of the 54 HUCs with reported commercial withdrawals, 91 percent of the withdrawals were less than $1 \mathrm{Mgal} / \mathrm{d}$.

Given the generally applied method of accounting for commercial withdrawals, it might be possible that these totals are underestimated in this and other accountings (Marilee Horn, U.S. Geological Survey, written commun., 2009). Many states in the basin and elsewhere base their estimated commercial withdrawals on amounts reported by well owners to mandatory or voluntary state inventory programs. Typically, these programs target users (and wells) withdrawing a minimum of $100,000 \mathrm{gal} / \mathrm{d}$ (70 gal/min). Because of this target, a substantial percentage of withdrawals associated with lower-capacity wells might be overlooked in accounting for commercial use. Even if underestimated, commercial withdrawals should be well less than public-supply withdrawals (about 3,800 Mgal/d, or 13 percent of basin totals). Commercial facilities relying on private supply wells generally are in less populated areas often either not served by public supply or served by comparatively small public-supply facilities, and commercial wells typically serve only a single facility. Realistically, actual self-supplied commercial withdrawals are expected, at most, to approximate those of self-supplied domestic or other lower-demand uses in the basin, none of which were estimated to exceed $600 \mathrm{Mgal} / \mathrm{d}$ (or 2 percent of basin totals). In a rigorous accounting of water use in a multicounty region of New Hampshire, Horn and others (2008) estimated about 3 percent of total withdrawals were self-supplied commercial withdrawals.

\section{Mining}

Mining water use is water for the extraction of solid, liquid, or gaseous substances, such as coal, iron, sand, and gravel; crude petroleum; and natural gas. The category includes quarrying, milling (crushing, screening, washing, and floatation of extracted minerals), reinjecting extracted water for secondary oil recovery, and other operations associated with mining activities. Dewatering was not reported as a mining withdrawal unless the water was used beneficially, such as for dampening roads for dust control. Water withdrawals were 

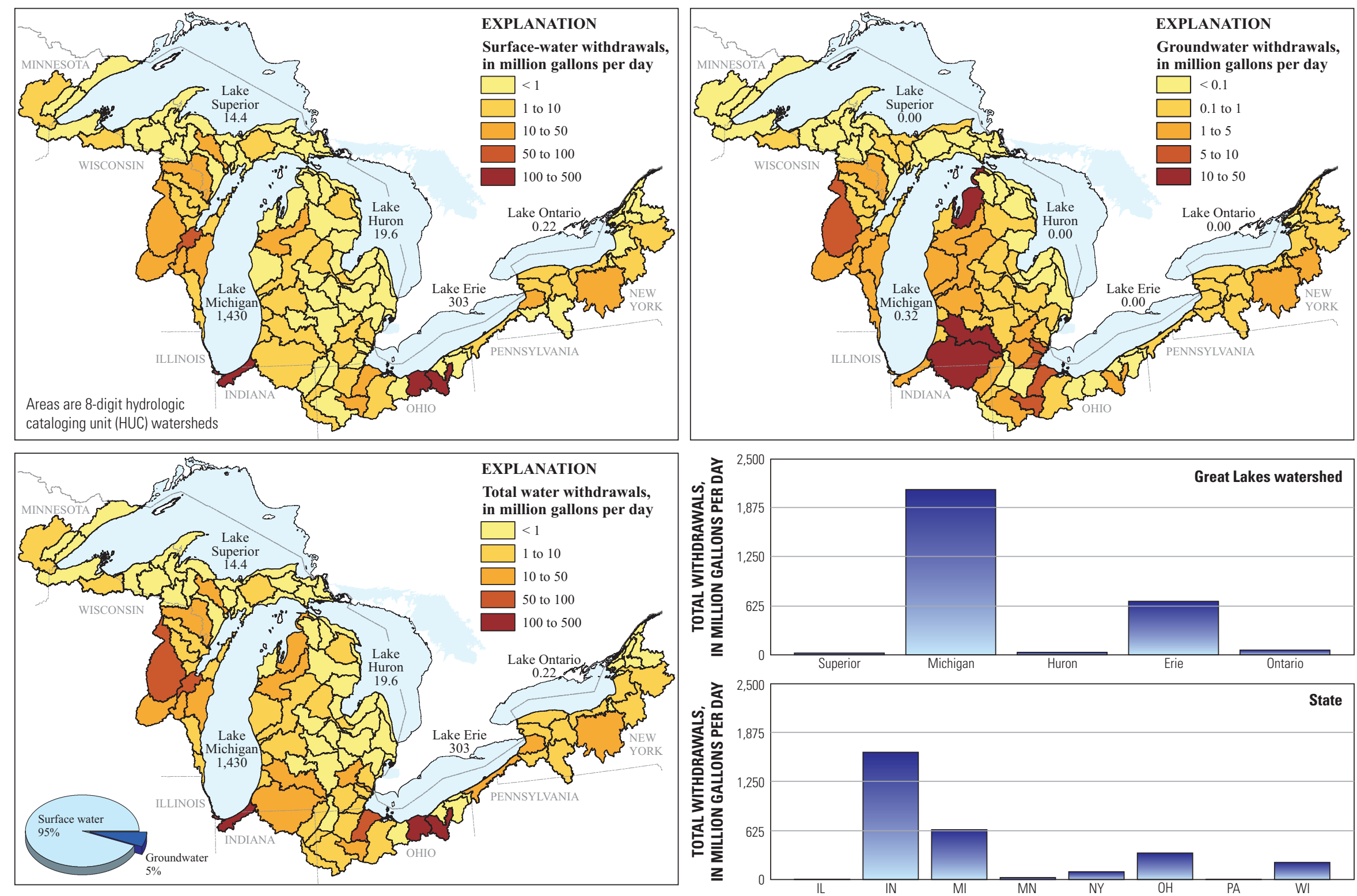

Figure 11. Industrial withdrawals by source, watershed, and state in the Great Lakes Basin, 2005. 
reported as freshwater or saline water, because the extraction of saline water has been indicated in past accountings of mining withdrawals in the basin.

For 2005, consumptive use was not a mandatory accounting element, and estimates in this category were compiled only by the USGS Ohio Water Science Center (provisional estimates for basin HUCs in Ohio can be found at http://water. usgs.gov/watuse/). On the basis of the mining-withdrawal estimates and data available from other sources, consumptive use is estimated for the basin and discussed briefly in the report section "Consumptive Use."

Mining withdrawals for 2005 are summarized by Great Lakes watershed and by state in table 9. Withdrawals and associated elements of water use are listed by individual HUC in appendix 1. For 2005, total withdrawals in the Great Lakes Basin for mining use were an estimated $514 \mathrm{Mgal} / \mathrm{d}$. Mining withdrawals were 2 percent of total withdrawals in the basin and 6 percent of total withdrawals for all categories of use excluding thermoelectric power. Surface water was the source for 89 percent of total withdrawals for mining. An estimated $309 \mathrm{Mgal} / \mathrm{d}$ was withdrawn from HUCs representing the Great Lakes (7.24 Mgal/d was reported as groundwater withdrawals), with about 96 percent of the withdrawals from Lake Superior. About 2 percent, or $1.20 \mathrm{Mgal} / \mathrm{d}$, of groundwater withdrawals for mining were saline; these saline withdrawals represented less than 0.004 percent of total withdrawals in the basin.

Table 9. Mining water withdrawals for Great Lakes watersheds and states in the Great Lakes Basin, 2005.

[Figures may not sum to totals because of independent rounding]

\begin{tabular}{|c|c|c|c|c|c|c|c|c|c|}
\hline \multirow{4}{*}{$\begin{array}{l}\text { Great Lakes } \\
\text { watershed }\end{array}$} & \multicolumn{9}{|c|}{ Withdrawals, in million gallons per day } \\
\hline & \multicolumn{6}{|c|}{ By source and type } & & & \\
\hline & \multicolumn{3}{|c|}{ Surface water } & \multicolumn{3}{|c|}{ Groundwater } & \multicolumn{3}{|c|}{ Total } \\
\hline & Fresh & Saline & Total & Fresh & Saline & Total & Fresh & Saline & Total \\
\hline Superior & 369.74 & 0.00 & 369.74 & 4.37 & 0.00 & 4.37 & 374.11 & 0.00 & 374.11 \\
\hline Michigan & 49.03 & .00 & 49.03 & 11.58 & .72 & 12.30 & 60.61 & .72 & 61.33 \\
\hline Huron & 10.45 & .00 & 10.45 & .37 & .14 & .51 & 10.82 & .14 & 10.96 \\
\hline Erie & 22.90 & .00 & 22.90 & 35.29 & .20 & 35.49 & 58.19 & .20 & 58.39 \\
\hline Ontario & 6.98 & .00 & 6.98 & 1.70 & .14 & 1.84 & 8.68 & .14 & 8.82 \\
\hline \multirow[t]{4}{*}{ TOTAL } & 459.10 & .00 & 459.10 & 53.31 & 1.20 & 54.51 & 512.41 & 1.20 & 513.61 \\
\hline & \multicolumn{9}{|c|}{ Withdrawals, in million gallons per day } \\
\hline & \multicolumn{6}{|c|}{ By source and type } & & & \\
\hline & \multicolumn{3}{|c|}{ Surface water } & \multicolumn{3}{|c|}{ Groundwater } & \multicolumn{3}{|c|}{ Total } \\
\hline State & Fresh & Saline & Total & Fresh & Saline & Total & Fresh & Saline & Total \\
\hline Illinois & 0.00 & 0.00 & 0.00 & 0.00 & 0.00 & 0.00 & 0.00 & 0.00 & 0.00 \\
\hline Indiana & 4.05 & .00 & 4.05 & .37 & .00 & .37 & 4.42 & .00 & 4.42 \\
\hline Michigan & 81.35 & .00 & 81.35 & 13.20 & .95 & 14.15 & 94.55 & .95 & 95.50 \\
\hline Minnesota & 354.74 & .00 & 354.74 & .02 & .00 & .02 & 354.76 & .00 & 354.76 \\
\hline New York & 8.61 & .00 & 8.61 & 2.06 & .25 & 2.31 & 10.67 & .25 & 10.92 \\
\hline Ohio & 5.51 & .00 & 5.51 & 31.42 & .00 & 31.42 & 36.93 & .00 & 36.93 \\
\hline Pennsylvania & .45 & .00 & .45 & .11 & .00 & .11 & .56 & .00 & .56 \\
\hline Wisconsin & 4.39 & .00 & 4.39 & 6.13 & .00 & 6.13 & 10.52 & .00 & 10.52 \\
\hline TOTAL & 459.10 & .00 & 459.10 & 53.31 & 1.20 & 54.51 & 512.41 & 1.20 & 513.61 \\
\hline
\end{tabular}


The Lake Superior watershed accounted for the majority of total withdrawals for mining use (73 percent; $370 \mathrm{Mgal} / \mathrm{d}$ ), as well as the majority of surface-water withdrawals (81 percent; $370 \mathrm{Mgal} / \mathrm{d}$ ) for such use. Iron-ore mining in Minnesota accounted for the largest surface-water withdrawals (Kenny and others, 2009). The Lake Erie watershed accounted for the majority of groundwater withdrawals (65 percent; $35.5 \mathrm{Mgal} / \mathrm{d}$ ), followed by the Lake Michigan watershed (23 percent; $12.3 \mathrm{Mgal} / \mathrm{d}$ ). The majority of salinewater withdrawals ( 60 percent; $0.72 \mathrm{Mgal} / \mathrm{d}$ ) occurred in the Lake Michigan watershed (solely within Michigan). Only minor saline-water groundwater withdrawals were recorded in the Lake Huron, Ontario, and Erie watersheds (0.14 to $0.20 \mathrm{Mgal} / \mathrm{d}$, respectively). Salt production from salt deposits, brine wells, petroleum exploration, and the presence of salt springs associated with buried salt deposits account for the saline-water withdrawals in the Great Lakes Basin; thick salt deposits underlie extensive areas of New York, Ohio, and Michigan (Sanford, 1995; Encyclopedia of Cleveland History, 2003; Michigan Department of Environmental Quality, 1994).

The distributions of total, total surface-water, and total groundwater withdrawals for mining use by HUC are shown in figure 12. The largest total water withdrawal, $296 \mathrm{Mgal} / \mathrm{d}$, was from Lake Superior. The largest total water withdrawals from land-based HUCs were in the Minnesota area of the St. Louis (04010201) (54.8 Mgal/d) and the Escanaba (04030110) of Michigan (18.6 Mgal/d). Surface-water withdrawals in these HUCs account for no less than 80 percent of the withdrawals and, as such, represent the largest surface-water withdrawals from land-based HUCs in the basin. The largest groundwater withdrawals were in the Sandusky (04100011) and Auglaize (04100007), primarily of Ohio (7.99, 5.45 Mgal/d, respectively), and the Ottawa-Stony (04100001), primarily of Michigan $(4.18 \mathrm{Mgal} / \mathrm{d})$. The largest saline groundwater withdrawal, $0.44 \mathrm{Mgal} / \mathrm{d}$, was in the Muskegon (04060102) of Michigan.

\section{Irrigation}

Irrigation water use includes water that is applied by an irrigation system to sustain plant growth in all agricultural and horticultural practices. Irrigation of golf courses, parks, nurseries, turf farms, cemeteries, and other self-supplied landscapewatering uses are included. Various applications associated with irrigation use include water applied for pre-irrigation, frost protection, application of chemicals, weed control, field preparation, crop cooling, harvesting, dust suppression, and leaching salts from the root zone; it also accounts for water lost in conveyance. Water for irrigation use may be delivered from a public supplier or be self-supplied. Irrigation water use in the Great Lakes States primarily is from self-supplied withdrawals. Deliveries from public supply were considered in this accounting of irrigation use only in the context of use of reclaimed wastewater (discussed in the report section "Reclaimed Wastewater"). All irrigation withdrawals are considered freshwater. Irrigated acres were reported by three types of irrigation methods: sprinkler, microirrigation, and surface flooding.

For 2005, irrigation consumptive use and conveyance losses were not mandatory accounting elements, and estimates in these categories were compiled only by the USGS Ohio Water Science Center (provisional estimates for basin HUCs in Ohio can be found at http://water.usgs.gov/watuse/). On the basis of the irrigation-withdrawal estimates and data available from other sources, consumptive use is estimated for the basin and discussed briefly in the report section "Consumptive Use."

At the discretion of individual USGS Water Science Centers, golf course irrigation withdrawals could be compiled and reported separately from crop-irrigation withdrawals; because golf course irrigation withdrawals were not compiled routinely and reported as a separate water-use category, estimates for total irrigation withdrawals are presented in this report. Withdrawal estimates for golf course irrigation were compiled for 97 HUCs within Illinois, Michigan, Minnesota, New York, and Ohio and thus are included in appendix 1 and discussed briefly. Because Michigan's HUC-designated watersheds represent the largest state area in the Great Lakes Basin, the discussion of golf course irrigation in this report focuses primarily on Michigan withdrawal estimates to indicate the extent of withdrawals for this use at the HUC scale in the basin.

Irrigation withdrawals and irrigated acres by irrigation system type are summarized by Great Lakes watershed and by state in table 10 . Withdrawals and associated elements of water use are listed by individual HUC in appendix 1. For 2005, total withdrawals in the Great Lakes Basin for irrigation use were an estimated $493 \mathrm{Mgal} / \mathrm{d}$, or 553 thousand acre-feet per year. Irrigation withdrawals were 2 percent of total withdrawals in the basin and 6 percent of total withdrawals for all categories of use excluding thermoelectric power. Groundwater accounted for 70 percent of the total irrigation withdrawals.

As indicated by the 8:1 proportion of crop to golf course irrigation withdrawals in Michigan and approximately 2:1 ratio in Ohio and New York, a substantial majority of the withdrawals in the basin were for agricultural irrigation. With 50 to 90 percent of the cropland of the basin states of Wisconsin, Michigan, Indiana, and Ohio in corn and soybean production and with the additional production of these crops in many other parts of the basin (U.S. Department of AgricultureNational Agricultural Statistics Service, 2007; 2009b), it is evident that the cropland irrigation withdrawals in the basin are, in large part, applied to row crops. About 750,000 acres were irrigated in 2005 , or less than 1 percent of the total land area of the basin. Of this total acreage, about 719,000 acres, or 96 percent of acres, were irrigated with sprinkler systems. Microirrigation mostly accounted for the remainder of irrigated acres. Application rates were estimated by dividing total withdrawals by irrigated acres. The average application rate for the basin was 0.74 acre-ft/acre.

The moderate climate of the basin restricts the growing season, with irrigation generally limited to a 3-4 month period from late spring to early fall. However, for consistency with the estimated withdrawal rates of other water-use categories, 

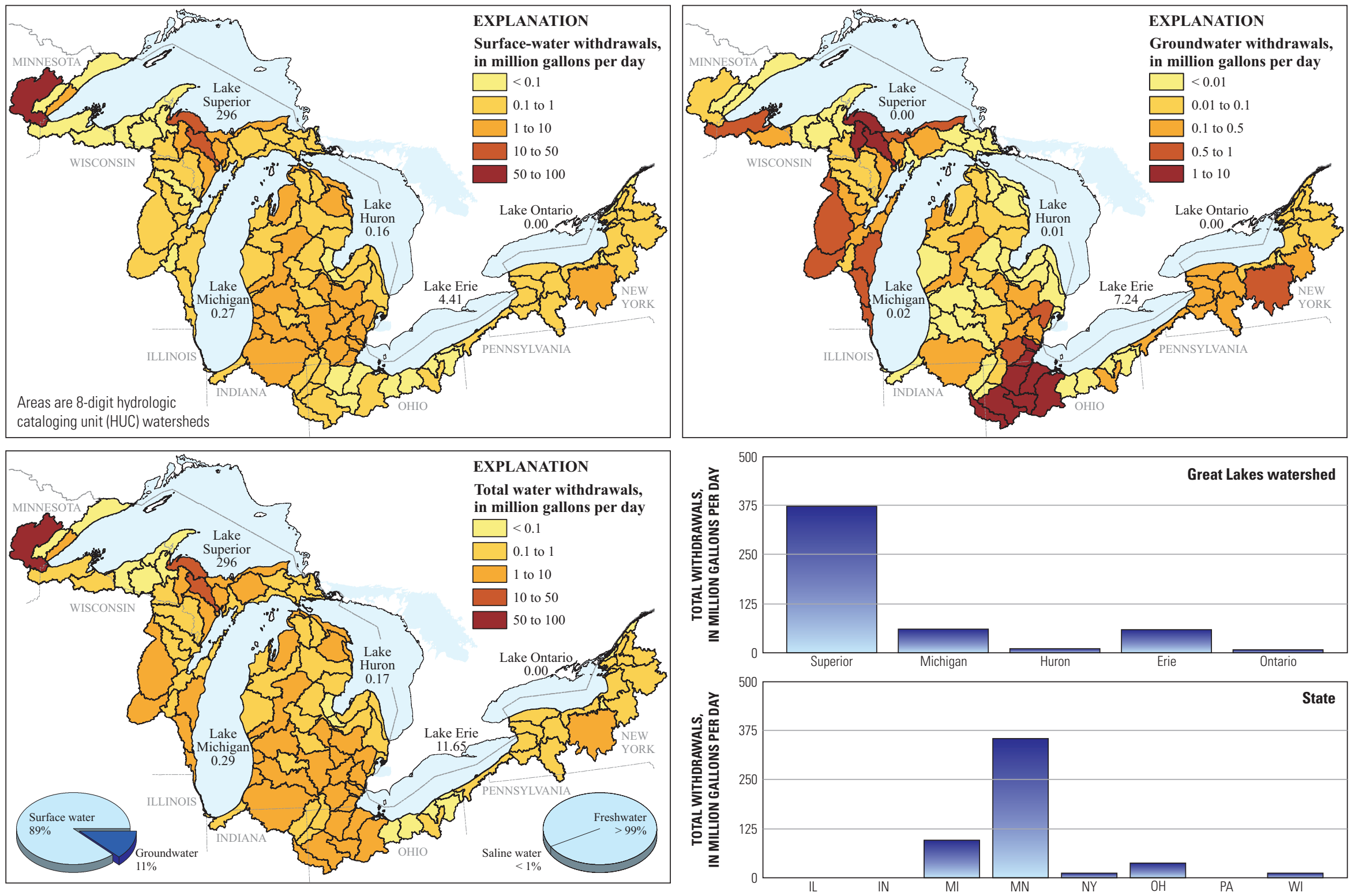



Figure 12. Mining withdrawals by source, watershed, and state in the Great Lakes Basin, 2005. 
Table 10. Irrigation withdrawals for Great Lakes watersheds and states in the Great Lakes Basin, 2005.

[Figures may not sum to totals because of independent rounding]

\begin{tabular}{|c|c|c|c|c|c|c|c|c|c|c|c|}
\hline \multirow[b]{3}{*}{$\begin{array}{c}\text { Great Lakes } \\
\text { watershed }\end{array}$} & \multicolumn{4}{|c|}{ Irrigated land, in thousand acres } & \multicolumn{3}{|c|}{ Withdrawals, in million gallons per day } & \multicolumn{3}{|c|}{ Withdrawals, in thousand acre-feet per year } & \multirow{3}{*}{$\begin{array}{c}\text { Application } \\
\text { rate, } \\
\text { in acre-feet } \\
\text { per acre }\end{array}$} \\
\hline & \multicolumn{4}{|c|}{ By type of irrigation } & \multicolumn{3}{|c|}{ By source } & \multicolumn{3}{|c|}{ By source } & \\
\hline & Sprinkler & Microirrigation & Surface & Total & Surface water & Groundwater & Total & Surface water & Groundwater & Total & \\
\hline Superior & 0.90 & 0.00 & 0.11 & 1.01 & 0.75 & 0.71 & 1.46 & 0.84 & 0.80 & 1.64 & 1.62 \\
\hline Michigan & 576.97 & 9.14 & 8.25 & 594.36 & 93.42 & 310.38 & 403.80 & 104.72 & 347.94 & 452.66 & .76 \\
\hline Huron & 36.80 & .67 & .40 & 37.87 & 13.24 & 13.87 & 27.11 & 14.84 & 15.55 & 30.39 & .80 \\
\hline Erie & 77.89 & 3.50 & .27 & 81.66 & 30.39 & 15.37 & 45.76 & 34.07 & 17.23 & 51.30 & .63 \\
\hline Ontario & 26.24 & 8.47 & .00 & 34.71 & 10.70 & 4.65 & 15.35 & 11.99 & 5.21 & 17.21 & .50 \\
\hline \multirow[t]{3}{*}{ TOTAL } & 718.80 & 21.78 & 9.03 & 749.61 & 148.50 & 344.98 & 493.48 & 166.47 & 386.72 & 553.19 & .74 \\
\hline & \multicolumn{4}{|c|}{ Irrigated land, in thousand acres } & \multicolumn{3}{|c|}{ Withdrawals, in million gallons per day } & \multicolumn{3}{|c|}{ Withdrawals, in thousand acre-feet per year } & \multirow{3}{*}{$\begin{array}{c}\text { Application } \\
\text { rate, } \\
\text { in acre-feet } \\
\text { per acre }\end{array}$} \\
\hline & \multicolumn{4}{|c|}{ By type of irrigation } & \multicolumn{3}{|c|}{ By source } & \multicolumn{3}{|c|}{ By source } & \\
\hline State & Sprinkler & Microirrigation & Surface & Total & Surface water & Groundwater & Total & Surface water & Groundwater & Total & \\
\hline Illinois & 0.33 & 0.00 & 0.00 & 0.33 & 0.27 & 0.44 & 0.71 & 0.30 & 0.49 & 0.80 & 2.41 \\
\hline Indiana & 72.81 & .00 & .00 & 72.81 & 5.23 & 26.88 & 32.11 & 5.86 & 30.13 & 36.00 & .49 \\
\hline Michigan & 474.04 & 10.33 & 5.85 & 490.22 & 110.41 & 197.67 & 308.08 & 123.77 & 221.59 & 345.36 & .70 \\
\hline Minnesota & .03 & .00 & .00 & .03 & .39 & .01 & .40 & .44 & .01 & .45 & 14.95 \\
\hline New York & 34.97 & 11.45 & .00 & 46.42 & 14.05 & 6.18 & 20.23 & 15.75 & 6.93 & 22.68 & .49 \\
\hline Ohio & 30.40 & .00 & .00 & 30.40 & 13.65 & 4.06 & 17.71 & 15.30 & 4.55 & 19.85 & .65 \\
\hline Pennsylvania & .99 & .00 & .00 & .99 & .45 & .14 & .59 & .50 & .16 & .66 & .67 \\
\hline Wisconsin & 105.23 & .00 & 3.18 & 108.41 & 4.05 & 109.60 & 113.65 & 4.54 & 122.86 & 127.40 & 1.18 \\
\hline TOTAL & 718.80 & 21.78 & 9.03 & 749.61 & 148.50 & 344.98 & 493.48 & 166.47 & 386.72 & 553.19 & .74 \\
\hline
\end{tabular}


the estimated irrigation rates are normalized to the year; that is, conceptually, the total irrigation withdrawals for the reporting year are distributed across the entire year as if the withdrawals took place every day of the year. Although crop and golf course irrigation represents a relatively small percentage of total water use in the basin, these withdrawals can have substantial impact on water availability for offstream and instream needs because the withdrawals occur primarily during summer months - when groundwater, stream, and lake levels generally are lower than at other times of the year - and at more intense rates than those represented by the annually normalized rates.

The Lake Michigan watershed accounted for the majority of total withdrawals ( 82 percent; $404 \mathrm{Mgal} / \mathrm{d}$ ) and irrigated acres (79 percent; 594,000) for irrigation use. This watershed also accounted for the majority of the surface-water withdrawals (63 percent; $93.4 \mathrm{Mgal} / \mathrm{d}$ and groundwater withdrawals (90 percent; $310 \mathrm{Mgal} / \mathrm{d}$ ) for such use. For states in the basin, Michigan accounted for 62 percent of total irrigation withdrawals, 74 percent of surface-water withdrawals, and 57 percent of groundwater withdrawals. Likewise, Michigan also accounted for the majority of irrigated acres ( 65 percent; 490,000 acres).

The distributions of total, surface-water, and groundwater withdrawals for irrigation use by HUC are shown in figure 13 . The largest total water withdrawal (175 Mgal/d) was in the St. Joseph (04050001) of Michigan and Indiana. This watershed, which is extensively farmed and is characterized by extensive permeable, coarse-grained soils (Friends of the St. Joe River Watershed, 2009), also accounted for the largest surfacewater withdrawal (52.7 Mgal/d) and groundwater withdrawal (123 Mgal/d). Irrigation withdrawals were reported in 104 (97 percent) of the basin's HUCs. With the exception of the St. Joseph and six other watersheds in Michigan and Wisconsin with a maximum of $69.0 \mathrm{Mgal} / \mathrm{d}$, total withdrawals in other Great Lakes Basin HUCs were less than $10 \mathrm{Mgal} / \mathrm{d}$ per HUC; total withdrawals were less than $1 \mathrm{Mgal} / \mathrm{d}$ in 54 percent of the HUCs. An estimated $6.22 \mathrm{Mgal} / \mathrm{d}$ was withdrawn from the Great Lakes, with 89 percent of the withdrawals from Lakes Michigan and Huron where they bound the State of Michigan.

Available estimates of withdrawals for golf course irrigation in the basin indicate from 11 percent (Michigan) to about 100 percent (Illinois) of total withdrawals for irrigation were for golf course irrigation. Collectively for the five reporting states, 11 percent of irrigation withdrawals were for golf course irrigation. Total volumes of water withdrawn for golf course irrigation, by state, ranged from less than $0.01 \mathrm{Mgal} / \mathrm{d}$ (Illinois) to as much as $33.7 \mathrm{Mgal} / \mathrm{d}$ (Michigan). Given that the basin areas and populations of Indiana and Wisconsin are somewhat similar in size to those of New York and Ohio and that each of these states has a mix of densely urbanized, suburban, and rural land uses, it might reasonably be assumed that the percentages (of total irrigation withdrawals) and volumes of golf course irrigation withdrawals in Indiana and Wisconsin, in a relative sense, approximate those in New York and Ohio (about 50 percent and $10 \mathrm{Mgal} / \mathrm{d}$, respectively). Given the somewhat similarly sized populations of Pennsylvania and Minnesota, it might reasonably be assumed that the percentages and volumes of golf course irrigation withdrawals in Pennsylvania approximate those in Minnesota (about 95 percent and less than $1 \mathrm{Mgal} / \mathrm{d}$ ). For the reporting states, withdrawals were from 2 to $4 \mathrm{Mgal} / \mathrm{d}$ in six HUCs in Michigan and one each in New York and Ohio; withdrawals were less than $1 \mathrm{Mgal} / \mathrm{d}$ in 77 percent of the HUCs.

For Michigan HUCs, golf course irrigation represented about 8 percent of the total irrigated acres. Groundwater accounted for 64 percent of the irrigation withdrawals. The largest total water withdrawal for golf course irrigation by HUC, 3.23 Mgal/d, was in the Clinton (04090003), which accounts for almost 10 percent of total golf course irrigation in Michigan. Generally, the most intensive golf course irrigation was restricted to heavily populated, southern Michigan watersheds similar to the Clinton watershed. About 1 percent of water withdrawn for golf course irrigation in Michigan is from the four Great Lakes that bound the State (Michigan Department of Environmental Quality, 2005).

\section{Aquaculture}

Aquaculture water use is associated with raising organisms that live in water - principally finfish in the Great Lakes Basin - for food, restoration, conservation, or sport. Aquaculture production occurs under controlled feeding, sanitation, and harvesting procedures, primarily in ponds, flowthrough raceways, and, to a lesser extent, cages, net pens, and closedcirculation tanks. Only freshwater withdrawals were compiled as part of the total. For this 2005 compilation, aquaculture use combines fish farm water-use activities of the former livestock subcategory, animal specialties, with fish-hatchery activities of the commercial category, as they were reported for the 1990 and 1995 compilations (Solley and others, 1993; 1998, respectively). For 2005, aquaculture consumptive use was not a mandatory accounting element, and estimates in this category were compiled only by the USGS Ohio Water Science Center (provisional estimates for basin HUCs in Ohio can be found at http://water.usgs.gov/watuse/).

Withdrawals for aquaculture for 2005 are summarized by Great Lakes watershed and by state in table 11. Withdrawals and associated elements of water use are listed by individual HUC in appendix 1. For 2005, total withdrawals in the Great Lakes Basin for aquaculture use were an estimated $141 \mathrm{Mgal} / \mathrm{d}$. Surface water was the source for about 80 percent of the withdrawals. Aquaculture withdrawals were less than 1 percent of total water withdrawals in the basin and 2 percent of total withdrawals for all categories of use excluding thermoelectric power.

The Lake Michigan watershed accounted for the majority of withdrawals for aquaculture use (56 percent; $79.6 \mathrm{Mgal} / \mathrm{d}$ ). For states in the basin, Michigan accounted for 46 percent (65.3 Mgal/d) of aquaculture withdrawals, with Wisconsin accounting for most of the additional withdrawals (36 percent; $50.9 \mathrm{Mgal} / \mathrm{d})$. 

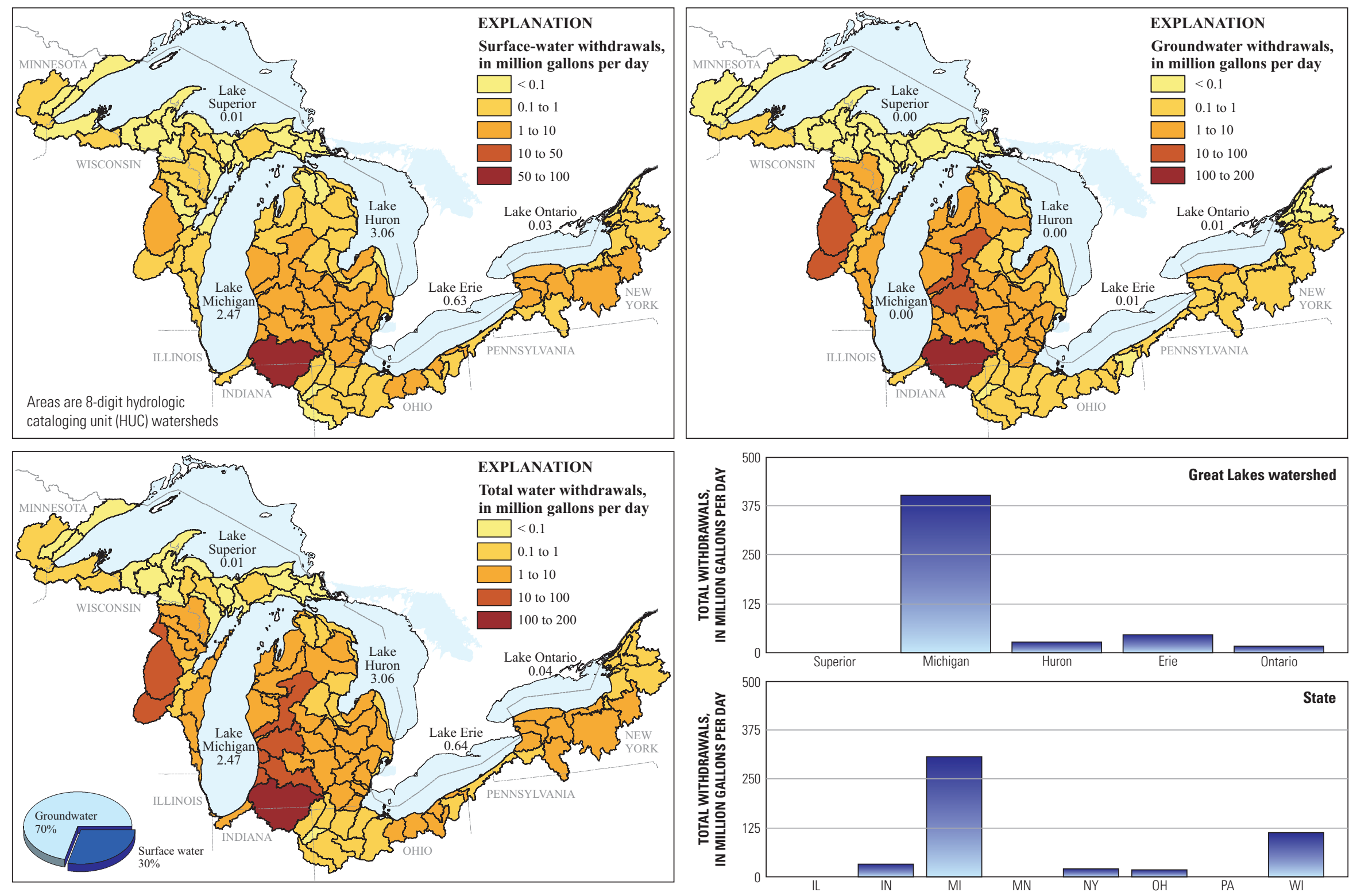

Figure 13. Irrigation withdrawals by source, watershed, and state in the Great Lakes Basin, 2005. 
The distributions of total, surface-water, and groundwater withdrawals for aquaculture by HUC are shown in figure 14. The largest total withdrawal, 32.4 Mgal/d, was in the Boardman-Charlevoix (04060105) of Michigan; all withdrawals within this HUC were surface-water withdrawals and accounted for the largest of that withdrawal source in the basin. The largest groundwater withdrawal, $5.50 \mathrm{Mgal} / \mathrm{d}$, was in the Upper Fox of Wisconsin (04030201). About 44 percent of withdrawals for aquaculture occurred in three HUCs, the Boardman-Charlevoix, and the Wolf (04030202) and Lake Superior waters of Wisconsin.

Table 11. Aquaculture withdrawals for Great Lakes watersheds and states in the Great Lakes Basin, 2005.

[Figures may not sum to totals because of independent rounding]

\begin{tabular}{|c|c|c|c|}
\hline \multirow[b]{3}{*}{$\begin{array}{c}\text { Great Lakes } \\
\text { watershed }\end{array}$} & \multicolumn{3}{|c|}{ Withdrawals, in million gallons per day } \\
\hline & \multicolumn{2}{|c|}{ By source } & \multirow[b]{2}{*}{ Total } \\
\hline & Surface water & Groundwater & \\
\hline Superior & 21.44 & 5.15 & 26.59 \\
\hline Michigan & 65.17 & 14.48 & 79.65 \\
\hline Huron & 7.25 & 1.39 & 8.64 \\
\hline Erie & 8.78 & 4.61 & 13.39 \\
\hline Ontario & 9.68 & 3.22 & 12.90 \\
\hline \multirow[t]{3}{*}{ TOTAL } & 112.32 & 28.85 & 141.17 \\
\hline & \multicolumn{3}{|c|}{ Withdrawals, in million gallons per day } \\
\hline & \multicolumn{2}{|c|}{ By source } & \\
\hline State & Surface water & Groundwater & Total \\
\hline Illinois & 0.00 & 0.00 & 0.00 \\
\hline Indiana & .00 & .00 & .00 \\
\hline Michigan & 62.39 & 2.95 & 65.34 \\
\hline Minnesota & .43 & .36 & .79 \\
\hline New York & 9.64 & 4.70 & 14.34 \\
\hline Ohio & 3.66 & .38 & 4.04 \\
\hline Pennsylvania & 3.45 & 2.34 & 5.79 \\
\hline Wisconsin & 32.75 & 18.12 & 50.87 \\
\hline TOTAL & 112.32 & 28.85 & 141.17 \\
\hline
\end{tabular}

\section{Livestock}

Livestock water use is water associated with livestock watering, feedlots, dairy operations, and other on-farm needs. Livestock includes dairy cows and heifers, beef cattle and cows, sheep and lambs, goats, hogs and pigs, horses, and poultry. Other livestock uses include cooling of facilities for the animals and products, dairy sanitation and washdown of facilities, animal waste-disposal systems, and incidental water losses. All withdrawals for livestock use are considered freshwater and are assumed to be self-supplied. The livestock category excludes on-farm domestic use, lawn and garden watering, and irrigation water use.

For 2005, livestock consumptive use was not a mandatory accounting element, and estimates in this category were compiled only by the USGS Ohio Water Science Center (provisional estimates for basin HUCs in Ohio can be found at http://water.usgs.gov/watuse/). On the basis of the livestockwithdrawal estimates and data available from other sources, consumptive use is estimated for the basin and discussed briefly in the report section "Consumptive Use."

For the 1990 and 1995 compilation of water use, the livestock category was split into the subcategories of livestock and animal specialties as specified in the 1987 Standard Industrial Classification manual (Office of Management and Budget, 1987). Withdrawals for fish farming and for watering horses were included in animal specialties. Beginning with the 2000 compilation, the livestock category has included the types of animals formerly included in animal specialties, with the exception of withdrawals for fish farms, which are included in aquaculture.

Livestock withdrawals for 2005 are summarized by Great Lakes watershed and by state in table 12 . Withdrawals and associated elements of water use are listed by individual HUC in appendix 1. For 2005, total withdrawals in the Great Lakes Basin for livestock use were an estimated $67.9 \mathrm{Mgal} / \mathrm{d}$. Livestock withdrawals were less than 1 percent of total withdrawals in the basin, as well as of total withdrawals for all categories of use excluding thermoelectric power. Groundwater was the source for 77 percent of livestock withdrawals.

The Lake Michigan watershed accounted for the majority of withdrawals for livestock use (54 percent; $36.7 \mathrm{Mgal} / \mathrm{d}$ ), including 61 percent $(31.8 \mathrm{Mgal} / \mathrm{d})$ of the groundwater withdrawals for such use. Surface-water withdrawals for livestock (15.6 Mgal/d) were distributed generally equally among the Great Lakes watersheds. For states in the basin, Wisconsin accounted for 31 percent of total livestock withdrawals and 36 percent of groundwater withdrawals for livestock; Michigan accounted for 29 percent of total livestock withdrawals and 34 percent of groundwater withdrawals. In large part, the dairy industry in Wisconsin and Michigan (U.S. Department of Agriculture-National Agricultural Statistics Service, 2009a,b) drives the comparatively large use of water for livestock in these and other states in the basin. Dairy cattle are the largest consumers of water on a daily basis among livestock (about 20-40 gal/d per animal; other livestock require about $10 \mathrm{gal} / \mathrm{d}$ 

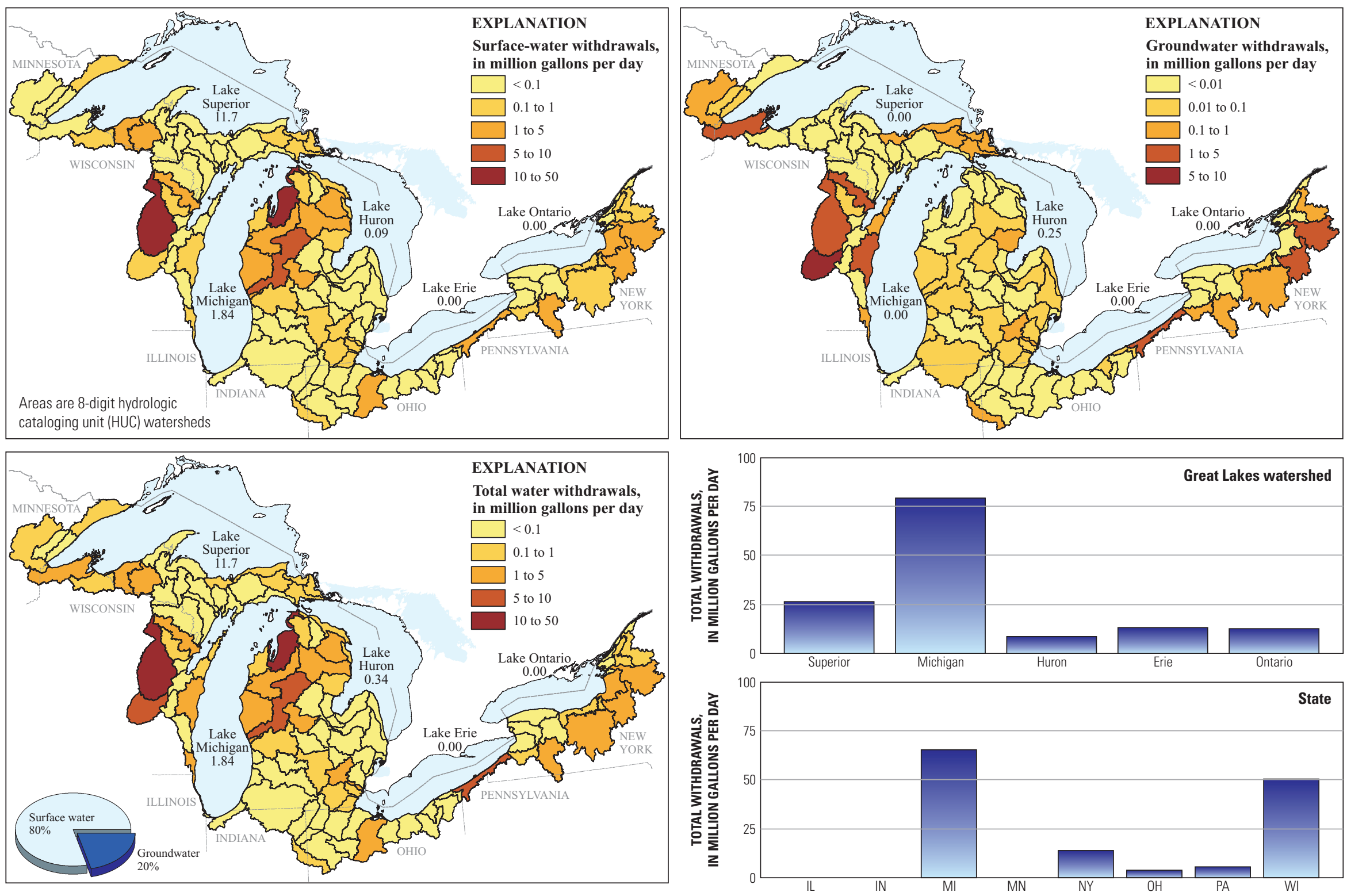

Figure 14. Aquaculture withdrawals by source, watershed, and state in the Great Lakes Basin, 2005. 
or less) (John K. Lovelace, U.S. Geological Survey, written commun., 2007).

The distributions of total, surface-water, and groundwater withdrawals for livestock by HUC are shown in figure 15 . The largest total withdrawals were in the Manitowoc-Sheboygan (04030101) of Wisconsin and St. Joseph (04050001) of Indiana and Michigan (5.73 and $5.58 \mathrm{Mgal} / \mathrm{d}$, respectively). The largest surface-water withdrawal, $1.73 \mathrm{Mgal} / \mathrm{d}$, was in the St. Joseph; and the largest groundwater withdrawal, $5.16 \mathrm{Mgal} / \mathrm{d}$, was in the Manitowoc-Sheboygan. About 34 percent of withdrawals for livestock occurred in six HUCs (three in Wisconsin; one each in Indiana-Michigan, New York, and Michigan).

Table 12. Livestock withdrawals for Great Lakes watersheds and states in the Great Lakes Basin, 2005.

[Figures may not sum to totals because of independent rounding]

\begin{tabular}{|c|c|c|c|}
\hline \multirow[b]{3}{*}{$\begin{array}{c}\text { Great Lakes } \\
\text { watershed }\end{array}$} & \multicolumn{3}{|c|}{ Withdrawals, in million gallons per day } \\
\hline & \multicolumn{2}{|c|}{ By source } & \multirow[b]{2}{*}{ Total } \\
\hline & Surface water & Groundwater & \\
\hline Superior & 0.03 & 0.71 & 0.74 \\
\hline Michigan & 4.87 & 31.82 & 36.69 \\
\hline Huron & .47 & 4.66 & 5.13 \\
\hline Erie & 5.84 & 6.75 & 12.59 \\
\hline Ontario & 4.46 & 8.25 & 12.71 \\
\hline \multirow[t]{3}{*}{ TOTAL } & 15.67 & 52.19 & 67.86 \\
\hline & \multicolumn{3}{|c|}{ Withdrawals, in million gallons per day } \\
\hline & \multicolumn{2}{|c|}{ By source } & \multirow[b]{2}{*}{ Total } \\
\hline State & Surface water & Groundwater & \\
\hline Illinois & 0.00 & 0.00 & 0.00 \\
\hline Indiana & 2.23 & 3.57 & 5.80 \\
\hline Michigan & 1.86 & 17.71 & 19.57 \\
\hline Minnesota & .00 & .24 & .24 \\
\hline New York & 5.38 & 9.93 & 15.31 \\
\hline Ohio & 4.07 & 1.65 & 5.72 \\
\hline Pennsylvania & .06 & .43 & .49 \\
\hline Wisconsin & 2.07 & 18.66 & 20.73 \\
\hline TOTAL & 15.67 & 52.19 & 67.86 \\
\hline
\end{tabular}

\section{Reclaimed Wastewater}

Reclaimed wastewater is wastewater-treatment-plant effluent that has been diverted for beneficial use before it reaches a natural waterway or aquifer. Wastewater effluent can be diverted for various uses, including industrial, irrigation, commercial, thermoelectric power, mining, and public and domestic supply. For this compilation and report, use of reclaimed wastewater was limited to industrial and irrigation use. For compilation of reclaimed wastewater use, null reporting of use was allowed; such reports were used for documented or suspected wastewater reuse that could not be verified or quantified or for uncertain use. Reclaimed wastewater use was not reported in 2000.

Reclaimed wastewater use in the Great Lakes Basin was estimated on the basis of very limited site-specific or countyaggregated data typically obtained from state or Federal permit programs that require reporting of return flows from wastewater-treatment plants and from individual facility inquiries. Estimates also were based on news accounts, conference presentations, and other qualitative reports regarding the reuse of wastewater.

Reclaimed wastewater use is summarized by Great Lakes watershed and by state in table 13 and listed by HUC in appendix 1. For 2005, no use of reclaimed wastewater in the Great Lakes Basin was reported by the USGS Water Science Center water-use specialists for their respective states. Five of eight states in the basin provided null reportings for all watersheds in their state because of the general absence of programs established for systematic accounting of this category of water use. Illinois, Indiana, and Ohio reported $0 \mathrm{Mgal} / \mathrm{d}$ for all watersheds, indicating that even if wastewater was being used in industrial or irrigation applications, it was at rates of less than $0.005 \mathrm{Mgal} / \mathrm{d}$ (minimum accounting amount, with rounding, was $0.01 \mathrm{Mgal} / \mathrm{d}$ ). Where use of reclaimed wastewater occurs in communities near the basin or in low quantities within the basin, its use appears to be principally for golf course irrigation (American Water Works Association, 2008). A notable exception is its substantial use for agricultural irrigation associated with the extensive operations of the Muskegon County (Michigan) Wastewater Management System (2009) (Muskegon HUC 04060102); recently obtained information indicates $18.9 \mathrm{Mgal} / \mathrm{d}$ was used in 2005 and an average of 18.1 Mgal/d was used during 2005-2009 (Dave Kendrick, Muskegon County Public Works, written commun., 2009). With the exception of the Muskegon, Mich. operations, wastewater reuse in and near the basin appears to be restricted primarily to a few large metropolitan areas, particularly that of Chicago, Ill., where about $17 \mathrm{Mgal} / \mathrm{d}$ of wastewater reuse for golf course irrigation was reported in 2005 (all of which was outside the basin) (Sergio Serafino, Metropolitan Waste Reclamation District of Greater Chicago, written commun., 2007).

Relative to its status in other parts of the Nation, reclaimed wastewater is virtually an unused water resource in the Great Lakes Basin. California, Florida, Arizona, and Nevada have been using reclaimed wastewater for decades 

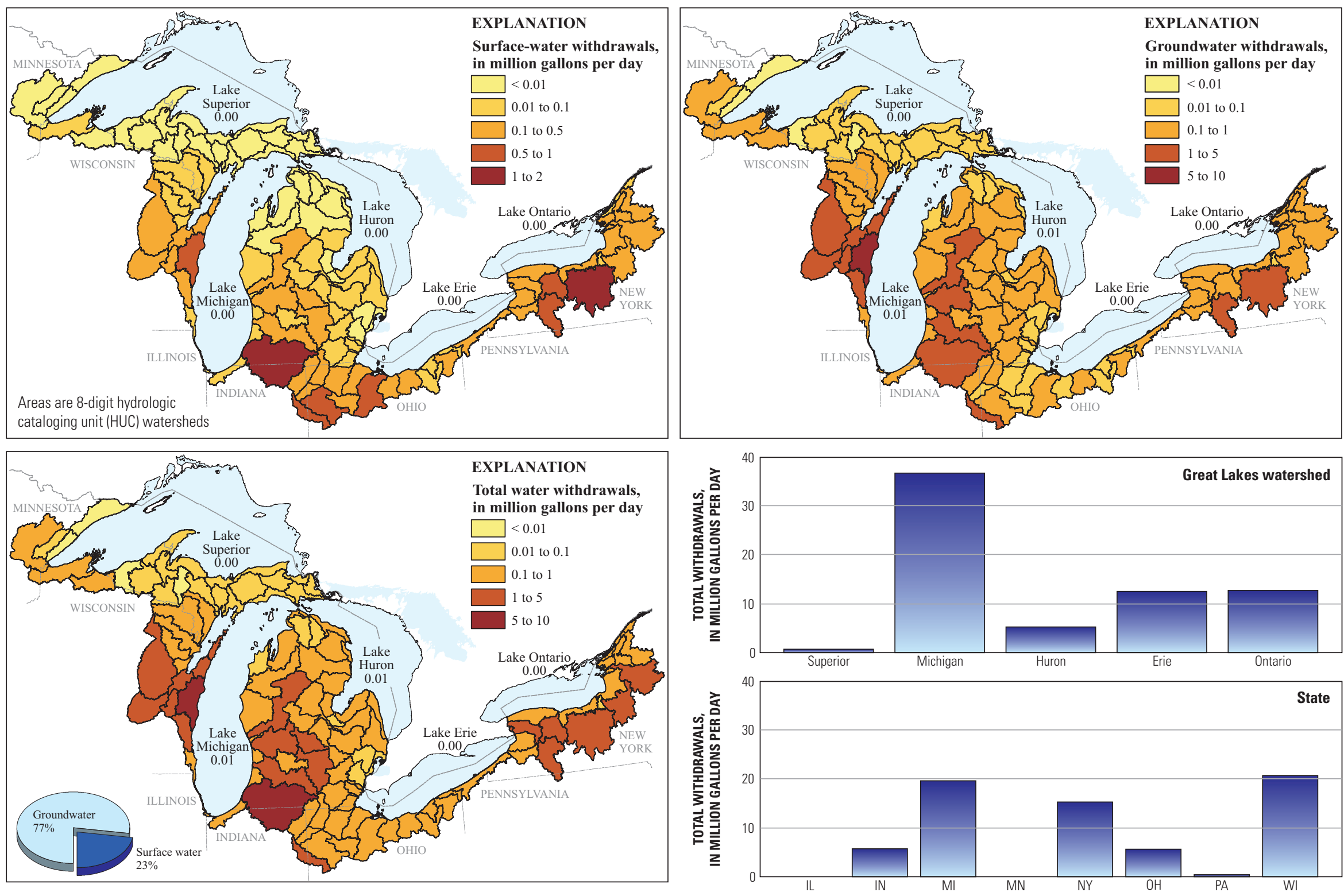

Figure 15. Livestock withdrawals by source, watershed, and state in the Great Lakes Basin, 2005. 
(Washington State Department of Ecology, 2005). In 1995, the last year these data were systematically compiled by the USGS, total use of reclaimed wastewater in these states, as well as Maryland and Texas, ranged from 24 to $260 \mathrm{Mgal} / \mathrm{d}$ (Solley and others, 1998); total use in the Nation was $718 \mathrm{Mgal} / \mathrm{d}$. With the exception of a total of about $100 \mathrm{Mgal} / \mathrm{d}$ used for industrial applications in Maryland and Florida, about 97 percent of reclaimed wastewater use in the Nation was for irrigation.

Table 13. Reclaimed wastewater use for Great Lakes watersheds and states in the Great Lakes Basin, 2005.

[U, unknown; Little to no information on use is available. Assumed limited, if any, use for the Great Lakes watershed compilation]

\begin{tabular}{|c|c|c|c|}
\hline \multirow[b]{3}{*}{$\begin{array}{l}\text { Great Lakes } \\
\text { watershed }\end{array}$} & \multicolumn{3}{|c|}{$\begin{array}{l}\text { Reclaimed wastewater, } \\
\text { in million gallons per day }\end{array}$} \\
\hline & \multicolumn{2}{|c|}{ By type } & \multirow[b]{2}{*}{ Total } \\
\hline & Industrial & Irrigation & \\
\hline Superior & 0 & 0 & 0 \\
\hline Michigan & 0 & 0 & 0 \\
\hline Huron & 0 & 0 & 0 \\
\hline Erie & 0 & 0 & 0 \\
\hline Ontario & 0 & 0 & 0 \\
\hline \multirow[t]{3}{*}{ TOTAL } & 0 & 0 & 0 \\
\hline & \multicolumn{3}{|c|}{$\begin{array}{l}\text { Reclaimed wastewater, } \\
\text { in million gallons per day }\end{array}$} \\
\hline & \multicolumn{2}{|c|}{ By type } & \multirow[b]{2}{*}{ Tota } \\
\hline State & Industrial & Irrigation & \\
\hline Illinois & 0 & 0 & 0 \\
\hline Indiana & 0 & 0 & 0 \\
\hline Michigan & $\mathrm{U}$ & $\mathrm{U}$ & $\mathrm{U}$ \\
\hline Minnesota & $\mathrm{U}$ & $\mathrm{U}$ & $\mathrm{U}$ \\
\hline New York & $\mathrm{U}$ & $\mathrm{U}$ & $\mathrm{U}$ \\
\hline Ohio & 0 & 0 & 0 \\
\hline Pennsylvania & $\mathrm{U}$ & $\mathrm{U}$ & $\mathrm{U}$ \\
\hline Wisconsin & $\mathrm{U}$ & $\mathrm{U}$ & $\mathrm{U}$ \\
\hline TOTAL & 0 & 0 & 0 \\
\hline
\end{tabular}

\section{Trends in Water Withdrawals, 1985-2005}

The USGS first compiled water-use estimates for 1950 and since has compiled these estimates every 5 years. As part of these compilations, withdrawals in each of the Great Lakes HUCs have been estimated and are readily available for 1985 , 1990, 1995, and 2005 (Great Lakes Basin only) (U.S. Geological Survey, 2009). Withdrawals also have been estimated and available for the entirety of the basin for 1955-1995 (MacKichan, 1951, 1957; MacKichan and Kammerer, 1961; Murray, 1968; Murray and Reeves, 1972, 1977; Solley and others, 1983, 1988, 1993, 1998). Estimated withdrawals within the Great Lakes Basin during 1985-2005 are summarized in table 14 and represented graphically in figures 16 and 17. Additionally, percentage change in withdrawals from 1995 to 2005 for each usage category, Great Lakes watershed, and state is presented in table 14. Trends in withdrawals by source of water (surface water and groundwater) and population are shown in figure 16 and withdrawals by category in figure 17.

Analysis of trends in water withdrawals, population, and other elements of water use should be considered with respect to the inconsistencies and inaccuracies typically associated with their estimation. Throughout the 50-year history of compilation of water use in the Great Lakes Basin by the USGS, use categories, their associated elements, and the operational boundary of the basin each have changed. The number of reported categories has increased, grouping of the categories has varied, and the elements that compose those categories have evolved. Before 1970 (Murray and Reeves, 1972; Murray, 1968), additional watersheds in upstate New York and Vermont were included in the area that is presently (2009) delineated as the basin. Methods of accounting and estimating water-use quantities also have differed to various extents for each 5-yr compilation. Because of the variability in categorizations of water use and basin area, the evaluation and discussion of withdrawal and other trends in this report focuses on the period 1985-2005, with greatest emphasis on the period 1995-2005. Estimates of withdrawals for this more recent decadal period are considered to be derived from more complete and accurate accountings than estimates for prior periods; there seemingly has been an increase in the voluntary and mandated reporting of withdrawals and other elements and a concurrent decrease in the reliance on usage coefficients for the estimations. Additionally, by focusing on this most recent decadal period, inconsistencies in the delineation of use categories employed for the various compilations are considered to be minimized.

During 1985-2005, total withdrawals in the Great Lakes Basin fluctuated to a small extent ( -2 to +5 percent) around 1985 totals but declined almost 7 percent from 1995 to 2005 (table 14A; fig. 16). As withdrawal totals fluctuated slightly during the 20-year period, the basin population steadily increased (about 8 percent from 1985 to 2005). These generally divergent trends are reflected in the decrease in gross per 
Table 14A. Trends in withdrawals by category of water use and source in the Great Lakes Basin, 1985-2005.

[Estimates for 1995 and earlier from Solley and others (1998). Estimates are in million gallons per day; percentage change is calculated from unrounded numbers]

\begin{tabular}{|c|c|c|c|c|c|}
\hline \multirow[b]{2}{*}{ Category } & \multicolumn{3}{|c|}{ Year $^{1}$} & \multicolumn{2}{|c|}{ Percentage change } \\
\hline & 1985 & 1990 & 1995 & 2005 & 1995-2005 \\
\hline Population, in millions & 21.22 & 21.30 & 21.72 & 22.91 & 6 \\
\hline \multicolumn{6}{|c|}{ Offstream use } \\
\hline Total withdrawals & $31,773.56$ & $32,265.75$ & $32,496.42$ & $30,309.52$ & -7 \\
\hline Thermoelectric power & 22437.36 & 22827.66 & $22,786.57$ & $21,939.98$ & -4 \\
\hline Public supply & 4071.83 & 4335.83 & $4,405.14$ & $3,811.16$ & -13 \\
\hline Industrial & 4399.05 & 4187.82 & $4,174.97$ & $2,929.87$ & -30 \\
\hline Mining & 252.61 & 254.87 & 395.78 & 513.61 & 30 \\
\hline Irrigation & 254.01 & 288.52 & 314.45 & 493.48 & 57 \\
\hline Domestic & 281.82 & 280.31 & 351.43 & 412.39 & 17 \\
\hline Livestock and Aquaculture $^{2}$ & 76.88 & 90.74 & 68.08 & 209.03 & 199 \\
\hline Reclaimed wastewater ${ }^{3}$ & 20.63 & .00 & .00 & .00 & 0 \\
\hline
\end{tabular}

Source of water

\begin{tabular}{crrrrr}
\hline Ground: & & & & & \\
Fresh & $1,130.81$ & $1,180.69$ & $1,462.90$ & $1,504.44$ & 3 \\
Saline & 4.53 & 4.83 & 4.59 & 1.20 & -74 \\
Surface: & & & & & \\
Fresh & $30,638.22$ & $31,080.23$ & $31,028.93$ & $28,803.88$ & -7 \\
Saline $^{4}$ & .00 & .00 & .00 & .00 & 0
\end{tabular}

${ }^{1}$ Estimates of water use were not compiled by watershed (hydrologic unit code) in 2000.

${ }^{2}$ Livestock only, 1985; includes fish hatcheries, 1990, 1995; includes aquaculture, 2005; excluding aquaculture in 2005, livestock is $67.86 \mathrm{Mgal} / \mathrm{d}$ (less than 1 percent change from 1995 withdrawals).

${ }^{3}$ In 1985, irrigation use only; no reported industrial use. In 1990-2005, no reported irrigation or industrial use.

${ }^{4}$ Estimates fom Solley and others (1998) for 1990 and 1995 were revised to properly indicate no saline surface-water withdrawals.

capita use (use for all purposes) of about 12 percent during 1985-2005 (from 1,500 to 1,320 gal/d). This decrease suggests more efficient or conservative use of water in recent years. There was a continuous increase in groundwater withdrawals of about 33 percent (from 11.4 to $15.1 \mathrm{Bgal} / \mathrm{d}$ ) between 1985 and 2005. However, total withdrawals remained about 95 percent from surface water and 5 percent from groundwater. Saline-water withdrawals, all of which are of groundwater, continue to represent only a small fraction (less than 0.01 percent) of total water withdrawals.

The increase in groundwater withdrawals is associated primarily with increases in withdrawals for irrigation and domestic use. Since 1985, surface-water withdrawals have fluctuated around approximately $31 \mathrm{Bgal} / \mathrm{d}$. However, from 1995 to 2005 these withdrawals declined 7 percent to $28.8 \mathrm{Bgal} / \mathrm{d}$. The decrease in surface-water withdrawals is associated primarily with decreases in industrial withdrawals, but also with decreases in thermoelectric-power and publicsupply withdrawals. It should be noted that a substantial part of the decline in industrial surface-water withdrawals likely represents a change in accounting for these withdrawals (as well as for groundwater withdrawals) in Michigan. For 1995 and earlier accountings, estimates of self-served industrial withdrawals in Michigan based on available limited information included publicly served withdrawals as self-served (Carol Luukkonen, U.S. Geological Survey, written commun., 
Table 14B. Trends in withdrawals by Great Lakes watershed and state in the Great Lakes Basin, 1985-2005.

[Estimated withdrawals are a total, for all categories of use. Estimates for 1995 and earlier from Solley and others (1998). Estimates are in million gallons per day; percentage change is calculated from unrounded numbers]

\begin{tabular}{|c|c|c|c|c|c|}
\hline \multirow[b]{2}{*}{$\begin{array}{c}\text { Great Lakes } \\
\text { watershed }\end{array}$} & \multicolumn{4}{|c|}{ Year } & \multirow[b]{2}{*}{$\begin{array}{l}\text { Percentage change } \\
\text { 1995-2005 }\end{array}$} \\
\hline & 1985 & 1990 & 1995 & 2005 & \\
\hline Superior & 679.72 & 808.48 & 849.55 & $1,002.37$ & 18 \\
\hline Michigan $^{1}$ & $15,932.96$ & $16,170.85$ & $16,553.49$ & $14,998.17$ & -9 \\
\hline Huron $^{2}$ & $1,448.40$ & $1,403.21$ & $1,457.72$ & $1,227.53$ & -16 \\
\hline Erie $^{1,3}$ & $11,057.49$ & $10,732.33$ & $10,605.35$ & $10,260.17$ & -3 \\
\hline Ontario $^{4}$ & $2,654.99$ & $3,150.88$ & $3,030.31$ & $2,821.28$ & -7 \\
\hline TOTAL & $31,773.56$ & $32,265.75$ & $32,496.42$ & $30,309.52$ & -7 \\
\hline
\end{tabular}

${ }^{1}$ Saline use is less than 0.01 percent of total water use.

${ }^{2}$ Saline use is 0.01 percent of total water use

${ }^{3}$ Withdrawals within the St. Clair and Detroit River watersheds are included in the Lake Erie watershed.

${ }^{4}$ Saline use is less than 0.02 percent of total water use.

\begin{tabular}{|c|c|c|c|c|c|}
\hline \multirow[b]{2}{*}{ State } & \multicolumn{4}{|c|}{ Year } & \multirow{2}{*}{$\begin{array}{c}\text { Percentage change } \\
\text { 1995-2005 }\end{array}$} \\
\hline & 1985 & 1990 & 1995 & 2005 & \\
\hline Illinois & $3,451.22$ & $4,054.84$ & $3,594.03$ & $1,801.34$ & -50 \\
\hline Indiana & $3,377.33$ & $3,239.83$ & $3,060.24$ & $2,593.77$ & -15 \\
\hline Michigan $^{1}$ & $11,384.20$ & $11,593.33$ & $12,022.28$ & $11,659.87$ & -3 \\
\hline Minnesota & 307.03 & 327.33 & 500.33 & 597.81 & 19 \\
\hline New York ${ }^{2}$ & $3,956.41$ & $4,611.66$ & $4,628.96$ & $4,086.23$ & -12 \\
\hline Ohio & $3,876.32$ & $3,489.72$ & $3,071.41$ & $3,532.79$ & 15 \\
\hline Pennsylvania & 387.83 & 172.70 & 90.87 & 48.63 & -46 \\
\hline Wisconsin & $5,033.22$ & $4,776.34$ & $5,528.30$ & $5,989.08$ & 8 \\
\hline TOTAL & $31,773.56$ & $32,265.75$ & $32,496.42$ & $30,309.52$ & -7 \\
\hline
\end{tabular}

${ }^{1}$ Saline use is less than 0.01 percent of total water use.

${ }^{2}$ Saline use is less than 0.07 percent of total water use.

2009). With consideration of this accounting issue, the noted decline in surface-water industrial withdrawals between 1995 and 2005 (historically about 90 percent of total industrial withdrawals) might be overstated by as much as $1.1 \mathrm{Bgal} / \mathrm{d}$.

Withdrawals among the five Great Lakes watersheds also were variable during 1985-2005. Some of the largest changes in use occurred from 1995 to 2005, particularly in the Lake Superior watershed, with an 18 percent increase in withdrawals, and in the Lake Huron watershed, with a
16 percent decrease in withdrawals (with both estimates presumably affected to some extent by the change that occurred in accounting for industrial withdrawals between 1995 and 2005). The increase in withdrawals in the Lake Superior watershed is attributed, in large part, to increases in thermoelectric-power withdrawals in Minnesota and Michigan and in mining withdrawals in Minnesota. The decrease in withdrawals in the Lake Huron watershed is attributed, in large part, to decreases in industrial withdrawals in Michigan. The 


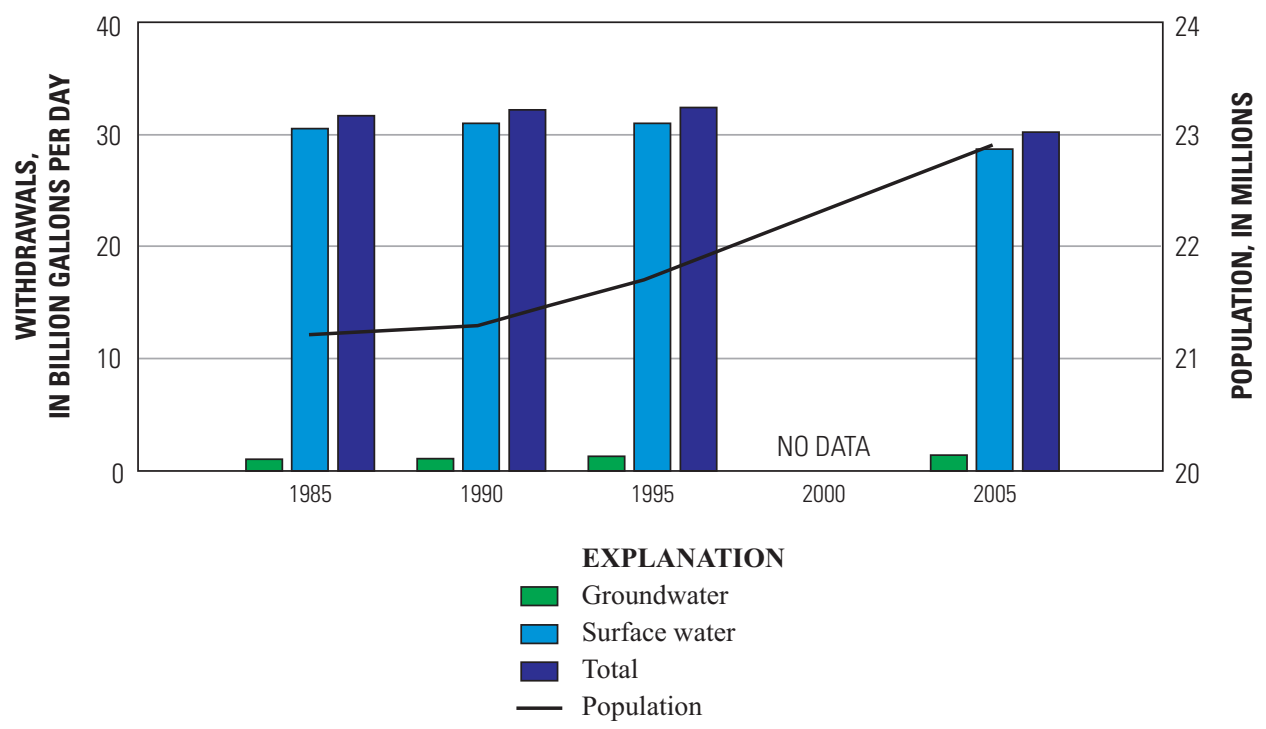

Figure 16. Trends in population and withdrawals by source in the Great Lakes Basin, 1985-2005.

decrease in total withdrawals throughout the basin during the past decade has been in response, in large part, to decreases in industrial withdrawals across most of the basin (excluding Ohio and Wisconsin), thermoelectric-power withdrawals in Illinois (near-shutdown of its one plant in the basin), and public-supply withdrawals in Michigan. By state, the largest volumetric increases in total withdrawals in the basin during the past decade were in Ohio and Wisconsin (each $461 \mathrm{Mgal} / \mathrm{d}$ ); the largest decrease was in Illinois $(1,790 \mathrm{Mgal} / \mathrm{d})$. In each of these states, the changes in total withdrawals primarily resulted from changes in thermoelectric-power withdrawals.

Following an increase in public-supply withdrawals in the basin during 1985-95, estimated withdrawals decreased by about 13 percent (fig. 17) from 1995 to 2005. Throughout the 1985-2005 period, groundwater use for public supply continued to represent only a small percentage (about 12 percent) of total water withdrawals for public supply.

Whereas the withdrawals for public supply decreased from 1995 to 2005, the population served by public supply during this decade increased by about 5 percent, suggesting more conservative use of water, more efficient distribution systems, and (or) reductions in deliveries to industrial-type users. The percentage of population served by public supply decreased from about 83 percent in 1985 to 77 percent in 2005, indicating greater reliance on self-supplied water, possibly associated with a population increase in more rural parts of the basin. From 1995 to 2005, the available population estimates indicate little additional change (1 percent decrease) in the percentage of population served by public supply. It is uncertain what factors might have contributed to this recent trend in percentage of population served by public supply. One contributing factor might have been an increase in rural watersupply systems as a source of water for those homeowners previously depending on use of their private wells. The reader is cautioned to consider the potential uncertainty of trend analysis based on population estimates, which is discussed further in the report section "Uncertainty in Estimates."

Estimated withdrawals for self-supplied domestic use in the basin increased 46 percent during 1985-2005, with a 17 percent increase from 1995 to 2005 . The increase in selfsupplied withdrawals reflects, in part, the population growth in the basin during the period. The self-supplied domestic population was about 3.7 million in 1985 , or about 17 percent of the total population; in 1995, it was about 4.9 million, or 23 percent of the total population. By 2005, 5.2 million people were self-supplied, although this number still represented about 23 percent of the total population. As with the trend in public-supply use, the 20-year trend in domestic use suggests, in part, a residential shift to less urbanized parts of the basin during 1985-95, followed by a changing trend in domestic use during the subsequent decade.

Withdrawals for thermoelectric-power generation consistently have represented the largest use of water in the Great Lakes Basin since the USGS began specific accounting of this basin use in 1965 . Throughout this period, almost 100 percent of withdrawals have been from surface-water sources. Peak use occurred during 1970-80, with maximum annual withdrawals of about $27 \mathrm{Bgal} / \mathrm{d}$. Between 1985 and 1995, estimated withdrawals for power generation increased about 2 percent, from 22.4 to $22.8 \mathrm{Bgal} / \mathrm{d}$; however, between 1995 and 2005, they decreased 4 percent to $21.9 \mathrm{Bgal} / \mathrm{d}$.

Federal legislation (U.S. Congress, 1972, 1977) that required stricter water-quality standards for return flows has played a role in trends in powerplant cooling-system designs and withdrawals in recent decades (Micheletti and Burns, 2002). Since the inception of that legislation, powerplants increasingly were built with, converted to, or added closedloop cooling systems or air-cooled cooling systems instead 


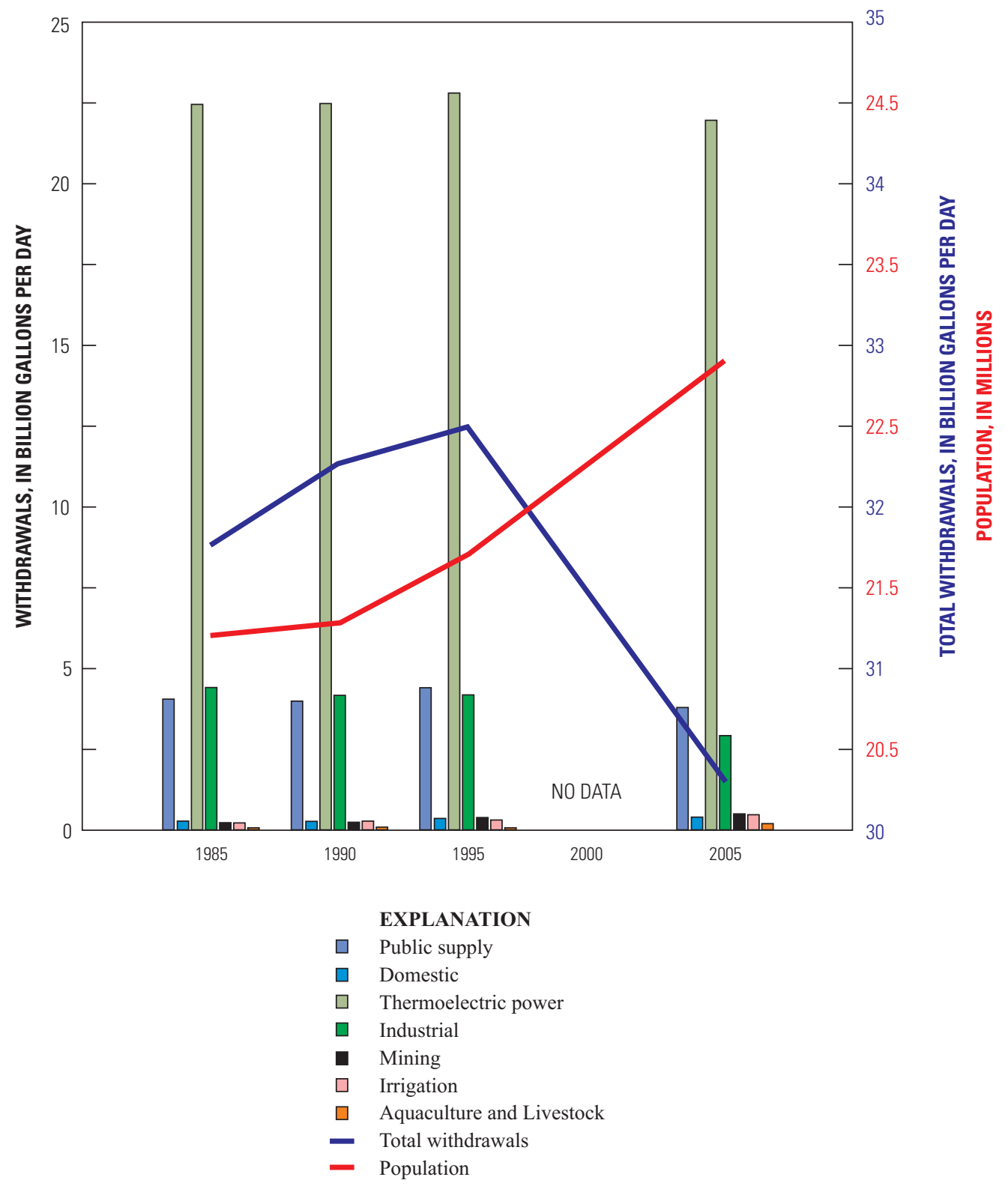

Figure 17. Trends in withdrawals by water-use category in the Great Lakes Basin, 1985-2005.

of exclusively using once-through cooling systems. Use of recirculated water in a closed-loop system reduces the overall intake requirement of a plant. Although resulting in reduced withdrawals, consumptive use may increase. Nationally, by 2000, 91 percent of water withdrawals for thermoelectric power were from powerplants equipped with once-through cooling systems; an alternative to once-through cooling was used in about 60 percent of the installed steam-generation capacity in the powerplants (Bozek, 2002). To evaluate historical trends in the use of various powerplant cooling systems in the Great Lakes Basin, a simplified approach was taken that considered readily available USGS water-use estimates. In 2005, 82 percent of withdrawals and 96 percent of power generation were from plants equipped with once-through cooling systems. From 1995 to 2005, there was a 7 percent increase in generated power in the basin coupled with the 4 percent decrease in withdrawals. One possible explanation of this trend could be that in recent years there has been an increase in the number of plants in the basin equipped with closedloop cooling systems or other alternatives to once-through cooling. However, during this same period, when all plants in the Great Lakes States both within and outside the basin are considered, the percentage of withdrawals attributed to plants with once-through cooling systems remained at 92 percent. Thus, any recent increases in the deployment of alternatives to once-through cooling in the basin seemingly are insubstantial. Although also lacking quantitative data, a Great Lakes Basin support group has expressed a similar conclusion that 
in recent years there have been few, if any, additional deployments of alternatives to once-through cooling systems in the basin's thermoelectric powerplants (Ed Glatfelter, Alliance for the Great Lakes, written commun., 2009). Concerns about the increased consumption of water associated with these types of cooling systems may, in part, account for the seemingly limited growth of closed-loop and related cooling systems in the basin. Alternatively, the 4 percent decrease in withdrawals during the past decade might be explained by increased efficiencies in the operation of the presently outfitted plants. Should there be increased use of closed-loop cooling systems in the basin's thermoelectric powerplants in future years, then a decrease in basin withdrawals and possibly an increase in consumptive use might be expected.

Industrial withdrawals in the basin have declined since their peak of about $9 \mathrm{Bgal} / \mathrm{d}$ during about 1965-70 (Murray, 1968; Murry and Reeves, 1972). This trend of declining withdrawals reflects the National trend (Solley and others, 1998; Hutson and others, 2004). During 1985-95, estimated withdrawals in the basin decreased 5 percent, from 4.4 to 4.2 Bgal/d. From 1995 to 2005 , the decline was a more dramatic 30 percent, from 4.2 to $2.9 \mathrm{Bgal} / \mathrm{d}$; as noted, as much as $1.1 \mathrm{Bgal} / \mathrm{d}$ (85 percent) of this decline might simply represent a change in how self-supplied industrial withdrawals in Michigan were estimated between the two accounting periods. During 1985-2005, the distribution between surface-water and groundwater withdrawals varied little, with surface-water withdrawals representing about 95 percent of total withdrawals. Virtually 100 percent of these withdrawals were freshwater, with saline-water withdrawals (in Michigan for industrial use) decreasing from highs of about $3.7 \mathrm{Mgal} / \mathrm{d}$ before 2005 to no reported withdrawals in 2005. Two principal factors likely have contributed to the trend of decreasing industrial withdrawals in the basin. Passage of Federal pollution-control legislation (U.S. Congress, 1972, 1977) required stricter water-quality standards for water discharges, which in turn, encouraged conservation, greater efficiency, less water-intensive technologies, and greater reliance on industrial deliveries from public suppliers. In 1985, $707 \mathrm{Mgal} / \mathrm{d}$ was delivered from public suppliers to industries in the basin; by 1995, about $773 \mathrm{Mgal} / \mathrm{d}$ was delivered. These deliveries represented about 16 percent of total industrial water use in 1985 and 19 percent by 1995 (delivery estimates for 2005 were not routinely compiled for this assessment). The decline in the number of manufacturing facilities in the basin since the late 1970s possibly also has contributed to the decrease in industrial withdrawals (City-Data Forum, 2007).

Withdrawals for mining use in the basin increased substantially during 1985-2005, with a 103 percent increase in estimated withdrawals since 1985 and 30 percent increase since 1995 (from 396 to $514 \mathrm{Mgal} / \mathrm{d}$ ). The largest increases in withdrawals have been restricted primarily to the Lake Superior watersheds of Minnesota, where the largest mining withdrawals occur. Surface-water withdrawals have consistently represented about 90-95 percent of total withdrawals for mining use. The percentage of saline water used in mining has remained consistently well less than 1 percent of total water withdrawals and total mining withdrawals.

With the exception of a decrease of about 15 percent from 1980 to 1985, withdrawals for combined crop and golf course irrigation in the basin increased steadily during 1960-2005. Estimated withdrawals increased 94 percent during 1985-2005 and 57 percent from 1995 to 2005 (from 314 to $493 \mathrm{Mgal} / \mathrm{d}$ ). This increase can be attributed primarily to an increase in crop and golf course irrigated acreage in the basin, particularly from 1975 to 1980 , when irrigated crop acreage increased about 150 percent to about 300,000 acres, and during the 1990s in conjunction with the national boom (about 20-percent growth) in golf course construction (Kosin, 2008). In $2005,750,000$ acres in the basin were irrigated, an increase of 56 percent since 1985. Available estimates of golf course irrigation withdrawals from Michigan are indicative of recent (about 2000-2004) withdrawal trends throughout the basin. These estimates suggest that the rapid expansion of golf course development, and thus the increase in withdrawals for irrigation, has slowed in the past few years (Michigan Department of Environmental Quality, 2005). The generally normal to wet conditions throughout most of the basin in 2005 suggest that withdrawals for irrigation were not unusually affected by weather in that year, but such conditions can affect the total withdrawals in any given year. How meteorological conditions might have contributed to the variability of the 5-year use estimates were not specifically addressed in this study. Surface water historically has been the source of about 60 percent of the water withdrawn for irrigation in the basin. However, beginning in 1995, groundwater became the primary source, accounting for 54 percent of the withdrawals. By 2005, this percentage increased to 70 percent.

Since 1985, when the USGS first compiled estimates of irrigated acres by system type, most acres in the basin have been irrigated with sprinkler systems (96 percent in 2005). From 1995 to 2005, the average irrigation application rate increased from 0.63 to 0.74 acre-ft/acre. One of a number of possible explanations for this increase might be an increase in the percentage of crops with relatively larger water demands. To a minor extent, the decrease in percentage of acres irrigated by the relatively water-conservative method of microirrigation during this period (from 3.5 to 2.9 percent) also might have contributed to the increase in application rate.

Trend statistics for aquaculture are not included specifically in table 14, because individual withdrawals for its principal subcategories of use - fish farms and fish hatcheries - were included with other categories of use before 2005. Those categories include livestock/animal specialties use (fish farms) and commercial use (fish hatcheries). The greater magnitude of withdrawals used for aquaculture in the basin in 2005 (141 Mgal/d) relative to the 1995 accounting of withdrawals for livestock/fish farming use (68 Mgal/d) possibly indicates regional growth in withdrawals for aquaculture use in recent years. This growth is further indicated in available documents from Great Lakes Basin research and support groups (University of Wisconsin Sea Grant Institute, 2004). Alternatively, 
the apparent increase in aquaculture withdrawals may, in large part, result from the addition of withdrawals for fish-hatchery use previously accounted for in commercial use.

Withdrawals for livestock use in the basin remained relatively stable during 1985-2005, averaging about $76 \mathrm{Mgal} / \mathrm{d}$ (tables 12 and 14A). During this period, the combination of animal groups and fish-husbandry operations included in the use category varied somewhat. Livestock withdrawals, as presented in table 14, include use for fish farms during 1985-95; withdrawals for aquaculture, which include those for fish farms (and fish hatcheries), are presented along with livestock use for 2005. During 1985-95, water use for fish farms is presumed to have been small relative to other livestock uses. Estimated withdrawals for livestock use decreased from a recent high of $91 \mathrm{Mgal} / \mathrm{d}$ in 1990 to $68 \mathrm{Mgal} / \mathrm{d}$ in 1995, a decline of 25 percent. Withdrawals for livestock use stabilized during 1995-2005, with an estimated use of $68 \mathrm{Mgal} / \mathrm{d}$ in 2005.

On the basis of the estimates of wastewater reuse compiled by the USGS NWUIP, there seemingly has been very limited reuse of wastewater in the basin during the decades from 1965 to 2005 . The only evidenced reuse during this period was about $30 \mathrm{Mgal} / \mathrm{d}$ in 1980 and $21 \mathrm{Mgal} / \mathrm{d}$ in 1985; this reuse was exclusively for irrigation and was restricted to Michigan. It is probable that, in these accountings, some applications of wastewater reuse may have been overlooked. Accounting of wastewater reuse in the basin historically has been hampered by the lack of routinely collected and reported usage data. However, evidence from discussions with various government and nongovernment water-use professionals and from newspaper articles and other typically qualitative sources of information indicates that even with accurate accounting of wastewater reuse, its application in the basin is very limited. Available information does suggest recent expansion in wastewater reuse, primarily in urbanized areas of the basin, such as the Chicago metropolitan area. Most of this reuse seems to be for golf course and landscape irrigation. With increasing concerns about conserving available water supplies in the Great Lakes States (Injerd, 2005), notable expansion in the use of reclaimed wastewater in the basin in future years may be a possibility. Recently the Northeastern Illinois Regional Water Supply Planning Group (Meng and others, 2007) has shown interest in the subject, and a number of reuse-related workshops have been held in the Chicago region (Northeastern Illinois Regional Water Supply Planning Group, 2009). To effectively track wastewater reclamation and reuse in future years, additional data programs would need to be developed.

\section{Consumptive Use}

Consumptive water use is the portion of water withdrawn (for a particular category of use) that is evaporated, transpired, incorporated into products or crops, consumed by humans or livestock, or otherwise removed from the immediate water environment. Consumptive-use totals in the Great Lakes Basin previously have been estimated by the USGS and the Great Lakes Commission, most recently by the USGS for 1995 (Solley and others, 1998) and by the GLC for 2004 (Great Lakes Commission, 2006). Water-use categories, study areas, and consumptive-use coefficients used in these assessments varied somewhat, but generally the estimates of consumptive use were similar when considered on the basis of total water use in the basin (U.S. part) for all categories of use (excluding hydroelectric-power withdrawals). For 1995, the USGS estimated 5.1 percent of the total water withdrawn, or $1,580 \mathrm{Mgal} / \mathrm{d}$, were consumed; for 2004, the GLC estimated 5.6 percent, or $1,460 \mathrm{Mgal} / \mathrm{d}$.

Consumptive use in the Great Lakes Basin and climatically similar areas also has been extensively explored by Shaffer and Runkle (2007), Shaffer (2009), and Pebbles (2003a,b). The investigations by Shaffer and Runkle and by Shaffer were thorough reviews and statistical compilations of representative consumptive-use coefficients for the various uses of water in the basin. As indicated in table 5 of Shaffer and Runkle (2007), the coefficients used and reported by various groups, agencies, and researchers for individual categories of use are varied. However, the median values of those coefficients are very similar to those used by the USGS and GLC in their previous estimations of consumptive use in the basin. Pebbles' study assessed the current state of knowledge of consumptive use in the basin and compiled information on consumptive use and the methods applied in the basin to estimate this aspect of water use.

To provide additional understanding of the extent of consumptive use in the basin, this use was estimated on the basis of the 2005 water withdrawal estimates of this report. The complexity of accurately estimating consumptive use cannot be understated. This complexity is well detailed in the abovementioned reports, to which the reader is referred (Shaffer and Runkle, 2007; Shaffer, 2009; Pebbles, 2003a,b). A simplified approach was taken in the present study to estimate consumptive use. This approach is based on the use of consumptive-use coefficients, in a manner that approximates that applied by many basin states and provinces for the estimates they annually submit to the GLC (Great Lakes Commission, 2006). As stated by Pebbles (2003a), "Notwithstanding the lack of documentation or scientific basis for the consumptive use coefficients, state and provincial officials generally believe that the coefficients are worthwhile for providing a sense of consumptive use lost to various water uses."

For estimation of consumptive use, the total withdrawal associated with each category of use was multiplied by a single coefficient associated with that category of use. For this, the category-specific median consumptive-use coefficients derived by Shaffer and Runkle (2007) for the Great Lakes Basin and climatically similar areas typically were used (table 9 of that report). Intracategory variability in consumptive use was not specifically considered. This variability includes, for example, differences in consumption associated with various industrial operations, animal species, or domestic uses (such as laundering or car washing). For purposes of this assessment, 
intracategory variability was considered to be adequately represented by the use of the single coefficient.

For estimation of consumptive use associated with public supply and domestic use, Shaffer and Runkle (2007) derived a single coefficient to represent these combined categories of use. Their justification was that many of the reports used as sources for statistical derivation of the coefficient did not always clearly differentiate between these categories of use. For the estimation of consumptive use presented here, these categories were assessed separately, as done for the annual GLC water-use reports (Great Lakes Commission, 2006). The singular coefficient of 13 percent derived by Shaffer and Runkle (2007) was applied to both public-supply and domestic use. The approach is considered justified, as the same coefficient seemingly is applied to both categories of use by all states and provinces contributing consumptive-use estimates to the GLC. Additionally, for estimation of consumptive use associated with public supply, deliveries of water to other users and unaccounted-for use (including conveyance losses) were not specifically considered. Deliveries - such as to industrial, domestic, and commercial users - and unaccounted-for use were considered as undifferentiated components of publicsupply withdrawals. Thus, the relative contribution of each component to overall public-supply consumptive use will not be fully accounted for by use of a single coefficient. Although simplified, this estimation approach also appears to be similarly used by all contributors to the GLC water-use reports.

Estimates of consumptive use associated with commercial and aquaculture use were considered separately from the other categories of use. Commercial use was not routinely compiled by the USGS for 2005, so estimates of total withdrawals in the basin required additional assumptions to be made regarding these totals. Maximum commercial use in the basin was assumed to be 3 percent of total withdrawals (as discussed in the report section, "Industrial"); a consumptiveuse coefficient of 10 percent (Shaffer and Runkle, 2007) was applied, although another assessment by Shaffer (2009, table 5) indicates that average commercial consumptive use might be closer to 40 percent. In estimating consumptive use associated with aquaculture, consumptive-use coefficients can vary widely with respect to fish hatcheries (which generally are raceways) and pond-based fish-farm operations. Generally, there is substantially higher consumptive use associated with fish farming because of evaporative losses from the shallow ponds that are typically used in these operations (Shaffer and Runkle, 2007). Information on the distribution of withdrawals in the basin associated with these quite different aquaculture operations was not readily available. Without including this distribution information, Shaffer (2009, table 26) calculates an average aquaculture consumptive use of 5 percent based on withdrawal and return-flow data from Ohio operations. For purposes of the current study, it is assumed that this distribution and the derived coefficient of consumptive use are representative of the entirety of the basin. Should there be a disproportionately larger percentage of pondbased operations elsewhere in the basin, then basin-wide aquaculture consumptive use, as presented here, likely would be underestimated.

Table 15 presents an estimate for consumptive use in the Great Lakes Basin for 2005 withdrawals. Total consumptive use in the basin was an estimated 1,860 Mgal/d, or 6 percent, of total withdrawals. Consumptive-use totals were the greatest, about 400-500 Mgal/d each, for public-supply, irrigation, and thermoelectric-power uses. Total consumptive use in the basin is expected to be somewhat greater than that estimated because commercial and aquaculture use are not considered in the estimation. On the basis of the noted assumptions, commercial consumptive use of about $90 \mathrm{Mgal} / \mathrm{d}$ might be expected; additional consumptive use of about $7 \mathrm{Mgal} / \mathrm{d}$ might be expected for aquaculture. As previously noted, commercial and aquaculture consumptive use might be somewhat greater than these estimated quantities.

\section{Uncertainty in Estimates}

Estimates of withdrawal and other elements of water use presented in this report for the Great Lakes HUCs were compiled and developed by USGS water-use specialists, who analyzed data and information from various state, Federal, and local agencies and nongovernmental entities. These specialists also made estimates in the case of missing data from the various sources of available data, and prepared documentation that identified the sources of data and associated water-use information and methods used for the water-use estimations for their respective states. The availability and type of wateruse data varies by state and is dependent on state law, whether there is a water-permitting or water-use inventory program, and extent of program funding. This variability in the sources and types of available data can lead to substantial variability in the accuracy and reliability (referred to collectively as "quality") of the data and, consequently, uncertainty associated with the resulting water-use estimates. With regard to water-use estimation, "accuracy" refers to the closeness of measured or estimated values to actual values, and it includes comprehensiveness or completeness of the data (as in unaccounted-for use because of incomplete reporting by users). "Reliability" refers to the consistency of measurement or estimation, including reporting, and "uncertainty" is used qualitatively to describe potential errors and biases associated with measurements, calculations, and estimates.

Water withdrawals by most users are not metered, either directly as volumes (flow rates) or indirectly on the basis of other measured values (such as power consumption and pump rating and run time). Even when metered, these data may not be readily available to water-use researchers because users may prefer not to report them to established water-inventory programs, such inventory programs are not established, or the reporting criteria for these programs focuses on selected users (biased by the magnitude of withdrawals). When reported ("metered") withdrawal values are unavailable, withdrawals 
Table 15. Water withdrawals and consumptive use in the Great Lakes Basin, 2005.

[Consumptive-use coefficients are from Shaffer and Runkle (2007, table 9) and represent median values for the Great Lakes Basin and climatically similar areas ${ }^{1}$; commercial use not included in totals because this use was not routinely compiled for 2005; aquaculture use not included because no coefficient was reported; Mgal/d, million gallons per day; NA, not applicable; figures may not sum to totals because of independent rounding]

\begin{tabular}{lccc}
\hline Water-use category & $\begin{array}{c}\text { Withdrawals, } \\
\text { in Mgal/d }\end{array}$ & $\begin{array}{c}\text { Consumptive-use } \\
\text { coefficient, } \\
\text { in percent }\end{array}$ & $\begin{array}{c}\text { Consumptive use, } \\
\text { in Mgal/d }\end{array}$ \\
\hline Total withdrawals & 30,200 & NA & 1,860 \\
Public supply & 3,810 & 13 & 495 \\
Domestic & 412 & 13 & 54 \\
Thermoelectric power & 21,900 & 2 & 439 \\
Industrial & 2,930 & 10 & 293 \\
Mining & 514 & 13 & 67 \\
Irrigation & 493 & 91 & 449 \\
Livestock & 68 & 90 & 61 \\
\hline
\end{tabular}

${ }^{1}$ For this report, consumptive-use coefficient is defined as the percentage of water removed from the immediate environment (water body, surface-water or groundwater source) by evapotranspiration, transpiration, incorporation into products or crops, or consumption by humans or livestock. Great Lakes Basin and climatically similar areas refers to basins, parts of basins and states in the Great Lakes Basin as well as basins and states that are climatically similar to the Great Lakes Basin but not in this basin. Median values are calculated from about 100 to 200 published coefficients in references after either 1975 (mining), 1980 (industrial, irrigation, thermoelectric, livestock), or 1985 (domestic and public supply). In the above table, consumptive use is approximated by multiplying the consumptive-use coefficient by withdrawals and dividing by 100 ; consumptive use for total withdrawals is calculated by summing the consumptive use determined for each water-use category.

are often estimated either by using coefficients derived from focused representative studies of water use or by methods based on various ancillary data and assumptions; for example, livestock withdrawals are typically estimated on the basis of voluntarily reported and estimated livestock populations and animal-specific coefficients considered representative of daily water-demand requirements. The extent to which withdrawals are accurately metered or are estimated by other means can result in a wide range of uncertainty associated with those data.

The analyses and results presented herein include the assumption that water-use data reported by users to state and Federal inventory programs, or to others that compile such data, generally are representative of actual use; that is, it is assumed that good-faith efforts to accurately record or estimate the data are made by those furnishing the use data. However, for the most part, there are no comprehensive procedures in place to fully assess and quantify the quality of such efforts and data reporting. It is expected that most governmental and other water-use inventory programs incorporate some systematic quality-assurance (QA) procedures to improve the accuracy of their compiled data; these might include, among others, periodic site-verification visits, statistical analyses of data and trends, and comparative estimations. The degree and consistency to which these QA procedures are employed are uncertain. The USGS, as part of its national compilation, reviews the estimates compiled by each Water Science Center water-use specialist, with specific use of spatial and temporal trend analyses for identification of possible inaccuracies in the estimates. Other QA measures, including use of comparative estimations for validation purposes, also may be applied by various Water Science Center water-use specialists (Marilee Horn, U.S. Geological Survey, written commun., 2009).

The sources of withdrawal and other data, the quality of the data, and the resulting uncertainty in estimates for each water-use category, as compiled by each Great Lakes State, are examined briefly and qualitatively in the following sections of this report. The sources of water-use data and estimates by category and state are summarized in table 16 . The resulting discussion and summarized findings are intended to provide (1) an understanding of factors that contribute to varied quality and uncertainty in water-use estimates, and (2) a means for evaluating the relative impact the varied quality and uncertainty may have on water-resource planning and evaluations 
Table 16. Source of water-use data and estimates by category of use for states in the Great Lakes Basin, 2005.

[Source of data and estimates: 1, typically metered use from most major users are available from inventories compiled as part of State-mandated or voluntary reporting; 2, estimates derived from measurements or ancillary data for the majority of users are available from inventories compiled as part of State-mandated or voluntary reporting; 3 , estimates derived from data or information from various sources for many users, generally using coefficients; 4 , estimates generally based on limited data, often using assumptions or generalized coefficients. Bold-text ratings indicate estimates for the Great Lakes Basin watersheds (8-digit hydrologic cataloging units (HUCs)) are determined from site-specific data; otherwise, estimates generally were derived from county-use estimates on the basis of percentage of a watershed within a county; - , not applicable]

\begin{tabular}{|c|c|c|c|c|c|c|c|c|}
\hline Water-use category & Public supply & Domestic & $\begin{array}{c}\text { Thermoelectric } \\
\text { power }\end{array}$ & Industrial & Mining & Irrigation & Aquaculture & Livestock \\
\hline Withdrawals & 1 & 4 & 1 & 2 & $3^{1}$ & $3^{1,2}$ & $3^{1}$ & $3^{1}$ \\
\hline Population served & 2 & - & - & - & - & - & - & - \\
\hline Deliveries from public supply & - & 4 & - & - & - & - & - & - \\
\hline Acres irrigated & - & - & - & - & - & 2 & - & - \\
\hline Power generated & - & - & 1 & - & - & - & - & - \\
\hline Reclaimed water & - & - & - & $4^{3}$ & - & $4^{3}$ & - & - \\
\hline
\end{tabular}

${ }^{1}$ Insubstantial water withdrawals.

${ }^{2}$ Crop and golf course irrigation estimates principally derived by using rainfall-deficit approach (Avery, 1999).

${ }^{3}$ Insubstantial use of reclaimed wastewater.

Indiana

\begin{tabular}{|c|c|c|c|c|c|c|c|c|}
\hline Water-use category & Public supply & Domestic & $\begin{array}{c}\text { Thermoelectric } \\
\text { power }\end{array}$ & Industrial & Mining & Irrigation & Aquaculture & Livestock \\
\hline Withdrawals & 1 & 4 & 1 & 1 & 2 & 2 & $2^{1}$ & 2 \\
\hline Deliveries from public supply & - & 4 & - & - & - & - & - & - \\
\hline Power generated & - & - & 1 & - & - & - & - & - \\
\hline Reclaimed water & - & - & - & $4^{1}$ & - & $4^{1}$ & - & - \\
\hline
\end{tabular}

${ }^{1}$ Insubstantial water withdrawals and use of reclaimed wastewater.

Michigan

\begin{tabular}{|c|c|c|c|c|c|c|c|c|}
\hline Water-use category & Public supply & Domestic & $\begin{array}{c}\text { Thermoelectric } \\
\text { power }\end{array}$ & Industrial & Mining & Irrigation & Aquaculture & Livestock \\
\hline Withdrawals & 1 & 4 & 1 & 1 & 3 & $3^{1}$ & 3 & 3 \\
\hline Deliveries from public supply & - & 4 & - & - & - & - & - & - \\
\hline Acres irrigated & - & - & - & - & - & 2 & - & - \\
\hline Reclaimed water & - & - & - & $4^{3}$ & - & $4^{3}$ & - & - \\
\hline
\end{tabular}

${ }^{1}$ Crop irrigation estimates derived by using rainfall-deficit based agriculture-irrigation model (Andreson, J., Moen, T., and Ritchie, J., Baer, B., Johnson, J., Savona, C., Swartz, M., and Van Til, R., 2000); golf-course irrigation determined from site-specific withdrawal data.

${ }^{2}$ For watersheds that include the Detroit metropolitan area, estimation must account for substantial water transfers.

${ }^{3}$ Insubstantial use of reclaimed wastewater. 
Table 16. Source of water-use data and estimates by category of use for states in the Great Lakes Basin, 2005.—Continued

[Source of data and estimates: 1, typically metered use from most major users are available from inventories compiled as part of State-mandated or voluntary reporting; 2, estimates derived from measurements or ancillary data for the majority of users are available from inventories compiled as part of State-mandated or voluntary reporting; 3 , estimates derived from data or information from various sources for many users, generally using coefficients; 4 , estimates generally based on limited data, often using assumptions or generalized coefficients. Bold-text ratings indicate estimates for the Great Lakes Basin watersheds (8-digit hydrologic cataloging units (HUCs)) are determined from site-specific data; otherwise, estimates generally were derived from county-use estimates on the basis of percentage of a watershed within a county; - , not applicable]

\section{Minnesota}

\begin{tabular}{|c|c|c|c|c|c|c|c|c|}
\hline Water-use category & Public supply & Domestic & $\begin{array}{c}\text { Thermoelectric } \\
\text { power }\end{array}$ & Industrial & Mining & Irrigation & Aquaculture & Livestock \\
\hline Withdrawals & 1 & 4 & 1 & 1 & 2 & 1 & 3 & 3 \\
\hline Deliveries from public supply & - & 2 & - & - & - & - & - & - \\
\hline Reclaimed water & - & - & - & $4^{1}$ & - & $4^{1}$ & - & - \\
\hline
\end{tabular}

${ }^{1}$ Insubstantial use of reclaimed wastewater.

\section{New York}

\begin{tabular}{|c|c|c|c|c|c|c|c|c|}
\hline Water-use category & Public supply & Domestic & $\begin{array}{c}\text { Thermoelectric } \\
\text { power }\end{array}$ & Industrial & Mining & Irrigation & Aquaculture & Livestock \\
\hline Withdrawals & 1 & 4 & 1 & 3 & 3 & $4^{1}$ & 3 & 3 \\
\hline Deliveries from public supply & - & - & 4 & - & - & - & - & - \\
\hline Power generated & - & - & 1 & - & - & - & - & - \\
\hline Reclaimed water & - & - & - & $4^{2}$ & - & $4^{2}$ & - & - \\
\hline
\end{tabular}

${ }^{1}$ Crop-irrigation estimates derived by using coefficient: average acre-feet per acre of water applied by type of irrigation system.

${ }^{2}$ Insubstantial use of reclaimed wastewater.

Ohio

\begin{tabular}{|c|c|c|c|c|c|c|c|c|}
\hline Water-use category & Public supply & Domestic & $\begin{array}{c}\text { Thermoelectric } \\
\text { power }\end{array}$ & Industrial & Mining & Irrigation & Aquaculture & Livestock \\
\hline Withdrawals & 1 & 4 & 1 & 1 & 2 & 2 & 2 & 3 \\
\hline Deliveries from public supply & - & 4 & - & - & - & - & - & - \\
\hline Acres irrigated & - & - & - & - & - & 2 & - & - \\
\hline Reclaimed water & - & - & - & $4^{1}$ & - & $4^{1}$ & - & - \\
\hline
\end{tabular}

${ }^{1}$ Insubstantial use of reclaimed wastewater. 
Table 16. Source of water-use data and estimates by category of use for states in the Great Lakes Basin, 2005.—Continued

[Source of data and estimates: 1, typically metered use from most major users are available from inventories compiled as part of State-mandated or voluntary reporting; 2, estimates derived from measurements or ancillary data for the majority of users are available from inventories compiled as part of State-mandated or voluntary reporting; 3 , estimates derived from data or information from various sources for many users, generally using coefficients; 4 , estimates generally based on limited data, often using assumptions or generalized coefficients. Bold-text ratings indicate estimates for the Great Lakes Basin watersheds (8-digit hydrologic cataloging units (HUCs)) are determined from site-specific data; otherwise, estimates generally were derived from county-use estimates on the basis of percentage of a watershed within a county; - , not applicable]

\section{Pennsylvania}

\begin{tabular}{|c|c|c|c|c|c|c|c|c|}
\hline Water-use category & Public supply & Domestic & $\begin{array}{c}\text { Thermoelectric } \\
\text { power }\end{array}$ & Industrial & Mining & Irrigation & Aquaculture & Livestock \\
\hline Withdrawals & 1 & 4 & 1 & 1 & 3 & 2 & 3 & 3 \\
\hline Deliveries from public supply & - & 4 & - & - & - & - & - & - \\
\hline Power generated & - & - & 1 & - & - & - & - & - \\
\hline Reclaimed water & - & - & - & $4^{1}$ & - & $4^{1}$ & - & - \\
\hline
\end{tabular}

${ }^{1}$ Insubstantial use of reclaimed wastewater.

Wisconsin

\begin{tabular}{|c|c|c|c|c|c|c|c|c|}
\hline Water-use category & Public supply & Domestic & $\begin{array}{c}\text { Thermoelectric } \\
\text { power }\end{array}$ & Industrial & Mining & Irrigation & Aquaculture & Livestock \\
\hline Withdrawals & 1 & 4 & 2 & 3 & 3 & 4 & $3^{1}$ & 3 \\
\hline Deliveries from public supply & - & 3 & - & - & - & - & - & - \\
\hline Power generated & - & - & 1 & - & - & - & - & - \\
\hline Reclaimed water & - & - & - & $4^{2}$ & - & $4^{2}$ & 一 & - \\
\hline
\end{tabular}

${ }^{1}$ Estimated on the basis of use of selectively available withdrawal data, although often dated (pre-2000).

${ }^{2}$ Insubstantial use of reclaimed wastewater.

at various spatial scales of interest. Although not specifically considered in this examination-but certainly also contributing to the quality of the data-is the extent to which field studies, statistical analyses and models, and other tested QA measures are used by the USGS and others to enhance or validate estimation of water-use values.

The quality of withdrawal estimates (and associated elements of water use) is, in large part, a function of whether the estimates were derived from site-specific data attributable to specific HUCs (watersheds) or from county-aggregated estimates for the USGS national accounting of water use (using geographic apportionment or other areal-proportioning method). A principal assumption is that the withdrawal estimates of highest quality are those based on site-specific data, such as those identified in table 16 by bold typeface. However, one must recognize that various factors, including the percentage of reporting water users representing the various category of water use and the accuracy of the reported data, could limit this assumption to some extent. In some cases, well-tested models or other measures using aggregated information, particularly at the HUC scale with this study in mind, may yield more accurate estimations than those based solely on site-specific data.

Additionally, withdrawal estimates derived from direct or indirect metering generally are considered of higher quality than those determined by other methods. As with sitespecific data, other factors, including the accuracy of meter performance and reporting of metered data could limit this assumption to some extent. In such cases, well-tested models or other means of estimation might prove to be more accurate. Estimates derived from site-specific data compiled by states as part of a mandatory or well-established voluntary reporting/ inventory program also generally can be considered of higher quality than estimates determined by other methods. Through 
mandatory reporting requirements, the States of Indiana, Minnesota, and Ohio inventory site-specific water withdrawals for almost all categories of water use; presumably many of the users meter their use. The extent to which these state programs and others oversee and monitor the completeness and accuracy of the reported water withdrawals, however, is unknown and possibly differs between states and over the course of time as affected by variability in program funding and other factors.

Michigan and Wisconsin inventory site-specific withdrawals for public-supply, industrial, and thermoelectricpower use, with Michigan also inventorying site-specific withdrawals for golf course irrigation use. Reporting for all categories of use is voluntary in Illinois, with extensive site-specific records maintained principally for withdrawals associated with public-supply, industrial, and thermoelectricpower use. Mandatory reporting in New York and Pennsylvania within the Great Lakes Basin is limited to site-specific withdrawals for public-supply use. It is assumed in the current study, on the basis of the Illinois voluntary inventory program (Tim Bryant, Illinois State Water Survey, Illinois Water Inventory Program, oral commun., 2009), that compliance approaches 90 percent for state-mandated and well-established voluntary inventory programs.

In general, the quality of the withdrawal estimates of a particular category of use is considered to decrease as (1) reporting participation by that category of users in voluntary or state-mandated programs decreases, (2) estimates are derived from increasingly nonvalidated or outdated estimation methods, or (3) reliance on ancillary data increases. For example, estimates of irrigation withdrawal based on a recently validated relation between power consumption and withdrawals generally are considered of higher quality than estimates of domestic withdrawal based on estimated populations served and a generalized water-demand coefficient.

To some extent, reporting requirements or user targets may bias (underestimate) the withdrawal estimates associated with the data typically compiled by the state-mandated or voluntary inventory programs. These programs often target facilities or individual users withdrawing more than about $100,000 \mathrm{gal} / \mathrm{d}$. Collective withdrawals by those overlooked users individually withdrawing lesser volumes might be notable in some locales.

\section{Public Supply and Self-Supplied Domestic}

All public-supply withdrawals are estimated from sitespecific withdrawal data obtained from state-mandated or voluntary water-use or drinking-water inventory programs. HUC population estimates for 2005 were provided by the USGS NWUIP to each USGS Water Science Center. These estimates were derived from county (2005) and block group (2000) Federal census data (U.S. Department of Commerce, 2006; 2001, respectively) by using a geographic-proportioning method (based on the ratio of HUC and county land area) for those counties not fully within a single watershed. Sources of data and methods varied by state for estimating populations served by public supply. Most USGS Water Science Centers relied on 2005 (or 2000) Federal census data as a basis for this estimation, with the estimates obtained "as compiled" from the assisting state water-use inventory programs. When necessary to accommodate area-population constraints or otherwise improve their accuracy, these estimates were adjusted by various means. Estimates also were obtained from the U.S. Environmental Protection Agency Safe Drinking Water Information System (SDWIS) database (U.S. Environmental Protection Agency, 2007); were furnished by public-water suppliers using customer-account information; or were derived by using Federal census housing data for 1990 (proportion of households served by public supply) (U.S. Department of Commerce, 1992) in conjunction with 2005 census data.

HUC-delineated estimates or data for population served by public supply generally were not available from public suppliers or other sources. Additionally, appropriate sitespecific ancillary data that might allow reasonably accurate estimation of population served by public supply at the HUC level typically were not readily available. Such ancillary data might include, for example, the number of houses in the HUC attached to public supply. In most cases, county-based population-served estimates obtained from public suppliers, state water-inventory programs, or the SDWIS database served as the basis for HUC population-served estimates, with the HUC populations determined by using a geographic-proportioning method. Where large quantities of water are transferred between HUCs, adjustments to the available public-supplyserved population count often were necessary to ensure that these estimates did not exceed the resident population of the HUC. This adjustment included, among other methods, use of the estimated self-supplied domestic population to derive the public-supply-served population and population-proportioning statistics from previous years.

With the legal requirements of the Safe Drinking Water Act (U.S. Environmental Protection Agency, 2004), including the monitoring and public availability of water-quality information, it is expected that relatively complete and accurate accountings of various associated aspects of water quality, including water withdrawals, are available. Additionally, reporting of these data are required in most Great Lakes States as part of a state-mandated inventory program. These reported withdrawal data were available from all Great Lakes States. The public-supply facilities typically monitor withdrawals directly by metering or indirectly on the basis of rate and duration of pumping. Given the success of the voluntary inventory program in Illinois, where 90 percent of the State's publicsupply facilities reported their withdrawals in 2005 (Tim Bryant, Illinois State Water Survey, Illinois Water Inventory Program, oral commun., 2006), a similarly high percentage of reporting facilities, and thus accounted-for withdrawals, might be expected in other states with mandatory inventory programs. Those facilities not reporting to the Illinois inventory program were, to a great extent, smaller facilities serving rural populations. Thus, uncertainty associated with estimates for 
public-supply withdrawals could very well be least of all the water-use categories and of limited concern for water-resource evaluations at various spatial scales of interest, particularly larger scales.

Given the methods of estimating populations served by public supply, these estimates can, in many cases, be quite inaccurate, with potential for substantial overestimation or underestimation. Generally, estimation uncertainty is expected to be least for highly urbanized areas where few residents are self-supplied. However, in these and other areas where water is transferred between suppliers and across political boundaries or watersheds, estimation uncertainty can be compounded - and accounting for the various populations served often can be quite difficult. Although typically not applied in the basin accountings for 2005, there is potential for improving the accuracy of population-served estimates. For example, current site-specific records of households obtaining publicsupply water and information on water transfers might be made more available for estimations. Also, from this information and site-specific census data, improved estimation models using Geographic Information System (GIS) tools and (or) statistical techniques could be developed and applied. Presently, however, uncertainty associated with population-served estimates might very well be of concern for water-resource evaluations at various spatial scales of interest.

All self-supplied domestic withdrawals are estimated on the basis of the self-supplied domestic population of each watershed and a domestic per capita use coefficient. For most estimations, the self-supplied population is estimated by subtracting the population served by public supply from the watershed population. In some cases, such as in Illinois, this population is considered more accurately estimated by use of directly associated indicators such as domestic-well counts. Accounting of the self-supplied domestic population in Illinois is complicated by complex interbasin and intrabasin publicsupply water transfers; additionally, there are relatively few self-supplied domestic users within the basin that need to be considered. As previously discussed, estimates of HUC populations were furnished to each USGS Water Science Center by the USGS NWUIP, and populations served by public supply were estimated by various methods. Per capita use coefficients were obtained from state agencies, planning or research organizations, or technical literature. The coefficients varied throughout the basin states. With the exception of Wisconsin, and to a minor extent Pennsylvania and Ohio, a single coefficient was applied by each state without consideration of locational variability of water use as affected by climate, household income, or other factors. These statewide coefficients ranged from about $49 \mathrm{gal} / \mathrm{d}$ (Wisconsin average-based default) to $90 \mathrm{gal} /$ day (Illinois). Wisconsin typically applied variable coefficients (ranging from 7 to $172 \mathrm{gal} / \mathrm{d}$ ) derived from municipality-level domestic-use data. HUC-specific coefficients (ranging from 55 to $161 \mathrm{gal} / \mathrm{d}$ ) were applied to seven HUCs in Pennsylvania and Ohio. Typical coefficients used in four states ranged from 70 to $76 \mathrm{gal} / \mathrm{d}$.
Should the use of more regionally consistent coefficients be considered to more accurately represent domestic demand, then domestic withdrawals in the basin possibly would differ from those depicted in table 6. Michigan's total domestic withdrawals would be most affected (decrease) should these be estimated using a per capita use coefficient representing a regional "norm" of $75 \mathrm{gal} / \mathrm{d}$ rather than the presently used $86 \mathrm{gal} / \mathrm{d}$. Michigan has the largest self-supplied population in the basin. Estimated withdrawals for Wisconsin and Illinois also would be relatively affected (increase and decrease, respectively), on the basis of the difference between their present per capita use coefficient and that of the "norm" used in this consideration. Overall ranking of self-supplied withdrawals by individual Great Lakes watershed and state, however, likely would differ little, given the large self-supplied domestic population of Michigan and its large percentage of the basin's self-supplied withdrawals. The rankings for Wisconsin and Illinois would be affected little, because of their relatively small self-served populations and percentage of the basin's withdrawals.

Given the extent to which self-supplied domestic withdrawals are estimated, uncertainty associated with these estimates seemingly might be of concern for most waterresource evaluations. However, with self-supplied domestic withdrawals representing only about 1 percent of total withdrawals in most Great Lakes watersheds (6 percent in the Lake Huron watershed), estimation uncertainty probably would be of less concern for such larger-scale evaluations. Estimation uncertainty could be of increasingly greater concern as the spatial scales of evaluations become more local, particularly those of HUC scale or smaller. In 2005, withdrawals greater than $10 \mathrm{Mgal} / \mathrm{d}$ were restricted to eight HUCs in three states (Michigan, Indiana, New York), with maximum withdrawals within a single watershed limited to about $30 \mathrm{Mgal} / \mathrm{d}$.

\section{Thermoelectric Power, Industrial, and Mining}

Thermoelectric-power withdrawals and associated powergeneration statistics are estimated from site-specific data obtained from state-mandated and voluntary water-use inventory programs, state permitting programs, the Federal inventory program of the U.S. Department of Energy, Energy Information Administration (USDOE-EIA), or individual facilities. The primary source of withdrawal data was state-mandated water-use inventory programs. For other than nuclear-power facilities, the primary source of power-generation data, including net power-generation and plant-cooling type, was the USDOE EIA-767 database report (U.S. Department of Energy, Energy Information Administration, 2008a). Waterwithdrawal data for nuclear-power facilities exclusively were provided by sources other than the USDOE-EIA, as these data were no longer included in their annual EIA-767 database reports after 2000. Power-generation data for nuclear facilities were obtained primarily from the EIA-906/920 database report (U.S. Department of Energy, Energy Information Administration, 2008b). 
It is expected that relatively complete and accurate reports of water withdrawals and associated power-generation statistics typically were available from the various data sources for 2005. From a survey of powerplant operations and number of plant visits, Dziegielewski and Bik (2006) determined that the average cooling-water withdrawal rates required to be reported annually to USDOE-EIA are reasonably representative of actual use, because they typically are based on either pump-use criteria (capacity ratings and period of use) or metered use. Dziegielewski and Bik do note that some inaccuracy is inherent in the determining the reported withdrawals because of the complexities associated with plant operation. Additionally, the withdrawal data available from USDOE-EIA likely somewhat underestimate actual withdrawals and power generation associated with thermoelectricpower generation, because the EIA-767 report targets plants with generator nameplate ratings of $10 \mathrm{MW}$ or larger. Some reports of water withdrawals for net power generation likely include additional, but substantially lesser, withdrawal volumes associated with operation and maintenance of the plants (gross power generation) and (or) with cogeneration of heat. Given the relative completeness and accuracy of the reported withdrawals (and proportionally large withdrawal volumes required for net power generation), uncertainty associated with estimates for thermoelectric-power withdrawals could very well be of limited concern for water-resource evaluations at various spatial scales of interest, particularly larger scales. However, some caution likely should be exercised when including these withdrawal estimates in water-resource evaluations. With withdrawals from thermoelectric-power facilities representing about 72 percent of total withdrawals in the basin and withdrawal rates from these facilities greatly exceeding those of most other types of facilities or withdrawals for other water uses, errors in the measurement or reporting of these withdrawals could contribute to substantial errors in accounting of volumes and distribution of withdrawal stresses in such evaluations.

Industrial withdrawals are estimated principally from site-specific withdrawal data obtained from state-mandated and voluntary water-use inventory programs. Selected data for estimates were obtained from individual facilities and state or Federal permit programs that require reporting of industrial withdrawals or return flows. Additionally, estimates for New York were made by using employment numbers classified by industry group and per employee water-demand coefficients.

Because most industrial facilities are privately owned, there may be a greater likelihood of lower participation rate in voluntary water-inventory reporting programs by these facilities than that of public utilities (such as public supply and thermoelectric power facilities) that are subject to greater regulatory oversight. However, in Illinois, where water-use reporting is voluntary, typically about 90 percent of contacted facilities have responded to the State's recent water-use inquiries in recent years (about 2005 to present) (Tim Bryant, Illinois State Water Survey, Illinois Water Inventory Program, oral commun., 2007). A study by Pacific Institute (Morikawa and others, 2007) indicates a growing commitment by large companies (often large water users) to public reporting of their measured water use. In the Morikawa study, 85 percent of respondents indicated making these data available; however, some inconsistencies were identified in how these data were measured and reported. The findings of the study, thus, suggest a general commitment among most larger industrial water users to responsibly quantify and report their water use to others. Water use by smaller industrial facilities, however, might be somewhat underestimated. In particular, smaller facilities typically rely on the use of lower-capacity wells (less than 100,000 gal/d), which can be overlooked in established inventory programs. Given that site-specific data are available in virtually all basin states, and assuming that the response rate for mandatory and voluntary water-inventory programs elsewhere in the basin approximates the Illinois rate and that reported use is reasonably accurate, uncertainty associated with industrial withdrawal estimates could be of only limited concern for water-resource evaluations at various spatial scales of interest, particularly larger scales. However, with potential of underestimating use and with industrial withdrawals accounting for 10 percent of withdrawals in the basin, such uncertainty might be of increasing concern for waterresource evaluations as their spatial scale of interest becomes more local.

The USGS NWUIP furnished each USGS Water Science Center with estimates of mining withdrawals for the 2005 compilation. The estimates were based on coal-, mineral-, and quarry-production data for 2004 obtained from the USGS (Geologic Discipline, Minerals Information Team) and USDOE-EIA; estimation of withdrawals associated with oil and gas production were limited to high-production states outside the basin (Lovelace, 2009a). Coefficients derived from various sources were used for the estimates; sources included U.S. Census Bureau and U.S. Department of the Interior, Bureau of Mines, reports and withdrawal data collected by the USGS in individual states (Lovelace, 2009a; John K. Lovelace, U.S. Geological Survey, written commun., 2008). The USGS water-use specialists were responsible for determining the most reliable sources of information available for estimating water use for their respective states. For some States (Ohio, Indiana, Minnesota), site-specific withdrawal data, as reported to state-mandated water-inventory programs, were available and used for estimates.

Accuracy of estimating mining withdrawals from reported data, such as from state inventory programs, is affected by difficulty in determining the amount of water withdrawn solely for mineral extraction and processing. Water withdrawn for nonbeneficial uses, such as dewatering of quarries and mines, should be excluded in the USGS accounting. Because these data often are not readily available, withdrawal estimates for Minnesota, Indiana, and Ohio, and possibly other basin states, include an undetermined quantity of water used for dewatering. Although oil and gas production is limited in most of the basin, production is notable in parts of Michigan and Ohio but the associated water withdrawals typically were 
not included in the accounting. For some commodities, including sand, gravel, and stone products, water-use coefficients varied greatly (from near zero to several thousand gallons per ton) (John K. Lovelace, U.S. Geological Survey, written commun., 2008), thus necessitating the use of median or average coefficient values. These particular commodities are mined and processed throughout many parts of the basin.

Accounting issues associated with dewatering, oil and gas production, and coefficient variability for selected commodities indicate that estimation uncertainty associated with mining water withdrawals could very well be of concern for water-resource evaluations at more local spatial scales of interest (generally HUC scale or smaller). Given that mining withdrawals represent only about 1 percent of total water withdrawals in the basin, it is probable that uncertainty associated with these estimates would be of limited concern for evaluations of larger scales of interest, particularly basin-scale evaluations. Withdrawals greater than $5 \mathrm{Mgal} / \mathrm{d}$ are restricted to nine HUC watersheds in five states, with withdrawals greater than $10 \mathrm{Mgal} / \mathrm{d}$ restricted to three watersheds in Minnesota (maximum of $171 \mathrm{Mgal} / \mathrm{d}$ ). Of the nine watersheds, three are in Ohio and three in Minnesota, where site-specific withdrawal data are reported to the state.

\section{Irrigation, Aquaculture, and Livestock}

Three States (Indiana, Ohio, and Minnesota) relied primarily on site-specific withdrawal data obtained from state-mandated and voluntary water-use inventory programs to estimate irrigation withdrawals. The extent to which the irrigation withdrawals reported to state inventory programs were measured or estimated is uncertain. Five states (Michigan, Wisconsin, Illinois, New York, and Pennsylvania) relied, in part or entirety, on other than metered and reported use to determine irrigation withdrawals. Often based on coefficients, these estimation methods included use of irrigated acreage in conjunction with a crop water-demand coefficient and relations between power consumption of a pump and withdrawal rate or duration of pump use and the rated capacity of a pump. Irrigated acreage, with few exceptions, was obtained from the voluntary, survey-based U.S. Department of Agriculture, National Agricultural Statistics Service (USDANASS) Census of Agriculture (2007, 2008a). In Minnesota, irrigated acreage was obtained from that reported to the state inventory program.

Estimation methods, including coefficient-based methods, ideally include adjustments for climatic variables, system efficiencies, conveyance losses, and other irrigation practices such as pre-irrigation. However, there has been limited verification of the accuracy of reported withdrawals or testing of the estimation coefficients and controlling assumptions by comparison to measured withdrawals. In Illinois, comparison of coefficient-based irrigation estimates (rainfall-deficit method) to measured withdrawals at five sites in each of three counties found that estimates by the coefficient method varied from measured withdrawals by +37 to +55 percent
(Charles F. Avery, U.S. Geological Survey, written commun., 2007). A 2005 evaluation of water withdrawals in two counties estimated by using the rainfall-deficit method and "measured" by using a previously determined power-consumption coefficient (Imperial Valley Water Authority, 2007) found that the coefficient-based estimates for the counties varied from the measured withdrawals by -10 to +22 percent. Additionally, most coefficient-based methods that require accounting of irrigated acreage rely upon the USDA-NASS Census of Agriculture for these irrigation data. Typically there is a lag of 3 years or more between the most recent irrigated-acreage data available from the USDA-NASS census and the associated USGS 5-year compilation of water-use estimates. For the twocounty evaluation described above, this lag accounted for a difference of about +30 percent between withdrawal estimates based on more recent 2007 acreage data available from the USDA Farm Service Agency and the 2002 census-reported acreage. This time lag in acreage-data availability could result in notable error in irrigation estimates for areas experiencing rapid expansion in irrigation use.

Another potential source of error in estimation of irrigation withdrawals is the inconsistency in how withdrawals are reported from surface-water and groundwater sources, particularly for golf course irrigation. In Illinois, an undetermined percentage of groundwater withdrawn to fill or provide makeup water to irrigation ponds at golf courses is reported as surface-water withdrawals (Tim Bryant, Illinois State Water Survey, Illinois Water Inventory Program, written commun., 2009). Metering of the water is often at the point of pond withdrawal.

These studies suggest that irrigation-withdrawal estimates determined by means other than site-specific, direct measurement of withdrawal volumes or well-tested estimation methods based on up-to-date ancillary data probably should be used with caution. However, despite concerns about possible inaccuracies associated with estimation of irrigation withdrawals, uncertainty associated with these estimates could very well be of limited concern for water-resource evaluations at most spatial scales of interest. Irrigation withdrawals represent only about 2 percent of total water use in the basin, with use greater than $10 \mathrm{Mgal} / \mathrm{d}$ (maximum of about $90 \mathrm{Mgal} / \mathrm{d}$ ) limited to seven HUCs in Michigan, Wisconsin, and Indiana (where site-specific withdrawals are reported to the state). Uncertainty associated with these estimates could very well be of increasing concern for water-resource evaluations at more local spatial scales of interest (generally HUC scale or smaller).

The USGS NWUIP furnished each USGS Water Science Center with estimates of aquaculture withdrawals for the 2005 compilation. These estimates were made by using production and facility information from the USDA-NASS Census of Aquaculture (2008b) in conjunction with various water-use coefficients (Lovelace, 2009b). The USGS water-use specialists were responsible for determining the most reliable sources of information available for estimating water use for their respective states. For Ohio, withdrawal estimates were made by using site-specific data available from its State-mandated 
water-inventory program. Given that most of the estimates of aquaculture withdrawals for HUC watersheds in the basin were derived by using coefficients and that these coefficientbased estimates were derived from county estimates, uncertainty associated with these estimates could be of concern for water-resource evaluations at various spatial scales of interest, but particularly at more local scales (generally HUC scale or smaller). Aquaculture withdrawals occurred in 65 percent of the basin HUCs, ranging from 3 to $32 \mathrm{Mgal} / \mathrm{d}$ in $10 \mathrm{HUCs}$ in five states (Ohio, New York, Pennsylvania, Wisconsin, and Michigan). However, given that aquaculture withdrawals represent less than 1 percent of total water withdrawals in the basin, it is probable that uncertainty associated with estimates of these withdrawals would be of limited concern for evaluations at larger scales of interest, particularly basinscale evaluations.

The USGS NWUIP furnished each USGS Water Science Center with estimates of livestock withdrawals for the 2005 compilation. These estimates were made by using livestock population data obtained from the USDA-NASS Census of Agriculture (2007) in conjunction with livestock-specific water-demand coefficients (gallons of water use per animal per day (gal/animal/d)) (Lovelace, 2009c). No basin states require reporting of water withdrawals for livestock use or have available voluntarily submitted or systematically collected withdrawal data for livestock. Coefficients used for estimating withdrawals were furnished by agricultural extension agents or water-permitting agencies or obtained from research literature.

The coefficients used for the various categories of animals classified as livestock vary by Great Lakes State; variation within individual categories generally was by a factor of 3 or less. For example, the coefficients used for dairy cattle ranged from 18 to $40 \mathrm{gal} / \mathrm{animal} / \mathrm{d}$; in Wisconsin, the State with the largest dairy cattle population, a coefficient of $28 \mathrm{gal} / \mathrm{animal} / \mathrm{d}$ was used. Within the livestock category, dairy cattle have the largest water-use requirement and represent the majority of livestock withdrawals in the basin. Whereas this variation in coefficients used by the various Great Lakes States, in part, can be attributed to local effects of climate on animal watering and facility maintenance needs, the variation also can be attributed, in part, to inconsistent selection of applied coefficients. Possibly, some of the coefficients have not been recently updated to account for changes in livestockhusbandry practices. Uncertainty associated with estimation of withdrawals for livestock use is compounded by the standard use of areal proportioning to derive estimates for HUCs from those for counties.

The use of highly varied water-demand coefficients for estimation of livestock withdrawals suggests that uncertainty associated with estimates of these withdrawals could be of concern for water-resource evaluations at various spatial scales of interest. However, with notable dairy operations in various watersheds in Wisconsin, New York, and Michigan, the uncertainty of these withdrawal estimates could be of most concern for water-resource evaluations at more local spatial scales of interest (generally HUC or smaller). About 34 percent of withdrawals occurred in six HUCs. Given that livestock withdrawals represent less than 1 percent of total water withdrawals in the basin, it is probable that uncertainty associated with these estimates of withdrawals would be of limited concern for evaluations at larger scales of interest, particularly basinscale evaluations.

\section{Comparison with Great Lakes Commission Estimates}

As an additional indication of estimation uncertainty, the estimates of water withdrawals compiled for the USGS Great Lakes Basin Pilot were compared with those compiled by the various Great Lakes States for the annual Great Lakes Commission water-use report (Great Lakes Commission, 2006). Although both the USGS estimates and the GLC estimates are derived, to a great extent, on withdrawal data and estimates reported by users to the various Great Lakes States, the sources for the USGS and GLC estimates do not completely overlap, and unique methods of estimation are employed by the USGS for unreported usage. For the comparison, the most recently available estimates from the GLC are for 2004, whereas the USGS estimates represent use in $2005^{2}$. Therefore, noted discrepancies between the USGS and GLC withdrawal estimates can be explained by differences in the estimate methodologies, as well as temporal variability in use. Discrepancies in the estimates also may be associated with differences in category definitions used by the USGS and those used by the GLC. For example, the GLC includes a category designated "other" to account for certain miscellaneous uses (withdrawals), such as for maintaining levels for navigation and creation of fish and wildlife habitat. Some of the uses included in this category may be accounted for in one of the designated USGS categories, but others may be ones considered "nonbeneficial" and thus not included in the USGS accounting. For the comparison of estimates, some adjustments were made to associate them as similarly as possible. Additionally, withdrawals from the four New York HUCs (04159304-04159307) omitted in the accountings elsewhere in this report were included to better associate the USGS and GLC estimates for New York. For the comparison, the relative percent difference (RPD) method was used (U.S. Environmental Protection Agency, 1989). Results are presented in table 17.

Although some large discrepancies between the USGS and GLC estimates are evident in table 17, most of these are associated with categories involving relatively small quantities of water, so the differences in water quantities are small. The most notable discrepancies are in surface-water withdrawals for irrigation, livestock, and industrial use estimated for New

\footnotetext{
${ }^{2}$ A recently available report from the GLC (Great Lakes Commission, 2009) allows comparison of 2005 withdrawals within the Great Lakes Basin, as estimated by the USGS and GLC. The USGS estimate of total withdrawals is $31.17 \mathrm{Bgal} / \mathrm{d}$; the GLC estimate is $27.34 \mathrm{Bgal} / \mathrm{d}$ (RPD of -13). The principal discrepancy is between the estimated withdrawals for thermoelectric-power generation in Wisconsin (USGS, 5,987 Mgal/d; GLC, 3,578 Mgal/d).
} 
Table 17A. Comparison of surface-water-withdrawal estimates by the U.S. Geological Survey, 2005, and Great Lakes Commission, 2004, for the Great Lakes Basin.

[U.S. Geological Survey (USGS) estimates for 2005 and Great Lakes Commission (GLC) estimates for 20041. Estimation methods and water-use categories differ to some extent. Water-use estimates are in million gallons per day; relative percent difference ${ }^{2}$ is calculated from unrounded numbers; NA, not applicable; NE, not estimated]

\begin{tabular}{|c|c|c|c|c|c|c|c|c|c|c|c|c|}
\hline \multirow[b]{2}{*}{$\begin{array}{l}\text { Great Lakes Commission } \\
\text { water use category }\end{array}$} & \multicolumn{3}{|c|}{ Illlinois } & \multicolumn{3}{|c|}{ Indiana } & \multicolumn{3}{|c|}{ Michigan } & \multicolumn{3}{|c|}{ Minnesota } \\
\hline & USGS & GLC & $\begin{array}{c}\text { Relative } \\
\text { percent } \\
\text { difference }\end{array}$ & USGS & GLC & $\begin{array}{c}\text { Relative } \\
\text { percent } \\
\text { difference }\end{array}$ & USGS & GLC & $\begin{array}{c}\text { Relative } \\
\text { percent } \\
\text { difference }\end{array}$ & USGS & GLC & $\begin{array}{l}\text { Relative } \\
\text { percent } \\
\text { difference }\end{array}$ \\
\hline Total withdrawals & $1,800.56$ & $1,826.29$ & 1 & $2,479.70$ & $2,649.80$ & 7 & $10,758.87$ & $10,420.80$ & -3 & 589.20 & 566.94 & -4 \\
\hline Public supply ${ }^{3}$ & $1,021.04$ & $1,003.65$ & -2 & 110.08 & 125.09 & 13 & 882.61 & 896.95 & 2 & 34.30 & 35.94 & 5 \\
\hline Domestic $^{4}$ & 2.68 & 3.87 & 36 & 16.74 & 13.86 & -19 & NA & $\mathrm{NE}$ & NA & 1.33 & 1.73 & 26 \\
\hline Thermoelectric power & 758.32 & 799.95 & 5 & 727.86 & 766.10 & 5 & $9,144.84$ & $8,880.89$ & -3 & 190.23 & 182.36 & -4 \\
\hline Industrial $^{5}$ & 18.52 & 18.82 & 2 & $1,617.56$ & $1,738.74$ & 7 & 621.01 & 539.66 & -14 & 362.52 & 345.85 & -5 \\
\hline Irrigation $^{6}$ & NA & $\mathrm{NE}$ & NA & 5.23 & 4.65 & -12 & 110.41 & 103.30 & -7 & .39 & .39 & 0 \\
\hline \multirow[t]{2}{*}{ Livestock $^{7}$} & NA & NE & NA & 2.23 & 1.36 & -48 & NA & $\mathrm{NE}$ & NA & .43 & .67 & 44 \\
\hline & \multicolumn{3}{|c|}{ New York } & \multicolumn{3}{|c|}{ Ohio } & \multicolumn{3}{|c|}{ Pennsylvania } & \multicolumn{3}{|c|}{ Wisconsin } \\
\hline $\begin{array}{l}\text { Great Lakes Commission } \\
\text { water use category }\end{array}$ & USGS & GLC & $\begin{array}{c}\text { Relative } \\
\text { percent } \\
\text { difference }\end{array}$ & USGS & GLC & $\begin{array}{c}\text { Relative } \\
\text { percent } \\
\text { difference }\end{array}$ & USGS & GLC & $\begin{array}{c}\text { Relative } \\
\text { percent } \\
\text { difference }\end{array}$ & USGS & GLC & $\begin{array}{l}\text { Relative } \\
\text { percent } \\
\text { difference }\end{array}$ \\
\hline Total withdrawals & $3,995.94$ & $4,231.80$ & 6 & $3,407.72$ & $2,991.18$ & -13 & 40.98 & 43.34 & 6 & $5,712.91$ & $3,385.16$ & -51 \\
\hline Public supply & 500.98 & 649.76 & 26 & 533.44 & 526.90 & -1 & 31.36 & 32.31 & 3 & 246.94 & 240.16 & -3 \\
\hline Domestic $^{4}$ & .00 & 63.75 & 200 & 8.69 & .00 & -200 & .00 & .00 & 0 & .00 & .00 & 0 \\
\hline Thermoelectric power & $3,362.80$ & $3,252.03$ & -3 & $2,517.99$ & $2,293.50$ & -9 & .00 & .00 & 0 & $5,232.46$ & $2,958.00$ & -56 \\
\hline Industrial $^{5}$ & 94.43 & 254.67 & 92 & 326.22 & 156.85 & -70 & 5.66 & 7.79 & 32 & 194.64 & 187.00 & -4 \\
\hline Irrigation $^{6}$ & 14.44 & 4.35 & -107 & 13.65 & 11.95 & -13 & .45 & 1.04 & 79 & 4.05 & .00 & -200 \\
\hline Livestock $^{7}$ & 23.29 & 7.24 & -105 & 7.73 & 1.98 & -118 & 3.51 & 2.20 & -46 & 34.82 & .00 & -200 \\
\hline
\end{tabular}

${ }^{1}$ Great Lakes Commission (2006); as estimated for “All Facilities"; GLC “other” use may be included in USGS estimates; USGS estimates include those New York 8-digit watersheds (04159304 to 04150307) not included elsewhere in this report.

${ }^{2}$ U.S. Environmental Protection Agency (1989).

${ }^{3}$ For Illinois, public-supply withdrawals are included as an "Interbasin Diversion" in GLC accounting and public-supply withdrawals at one institution are excluded because they are included with domestic/ residential withdrawals, as defined by the GLC.

${ }^{4}$ Includes self-supplied residential, commercial, institutional use; for Pennsylvania and New York, does not include unreported withdrawals for commercial use.

${ }^{5}$ Includes manufacturing and mining use.

${ }^{6}$ Includes agriculture, landscape, and golf course use.

${ }^{7}$ Includes fish-hatchery and other aquaculture use. 
Table 17B. Comparison of groundwater-withdrawal estimates by the U.S. Geological Survey, 2005, and Great Lakes Commission, 2004, for the Great Lakes Basin.

[U.S. Geological Survey (USGS) estimates for 2005 and Great Lakes Commission (GLC) estimates for 2004' ${ }^{1}$. Estimation methods and water-use categories differ to some extent. Water-use estimates are in million gallons per day; relative percent difference ${ }^{2}$ is calculated from unrounded numbers; NA, not applicable; NE, not estimated]

\begin{tabular}{|c|c|c|c|c|c|c|c|c|c|c|c|c|}
\hline \multirow[b]{2}{*}{$\begin{array}{l}\text { Great Lakes Commission } \\
\text { water use category }\end{array}$} & \multicolumn{3}{|c|}{ Illlinois } & \multicolumn{3}{|c|}{ Indiana } & \multicolumn{3}{|c|}{ Michigan } & \multicolumn{3}{|c|}{ Minnesota } \\
\hline & USGS & GLC & $\begin{array}{c}\text { Relative } \\
\text { percent } \\
\text { difference }\end{array}$ & USGS & GLC & $\begin{array}{c}\text { Relative } \\
\text { percent } \\
\text { difference }\end{array}$ & USGS & GLC & $\begin{array}{c}\text { Relative } \\
\text { percent } \\
\text { difference }\end{array}$ & USGS & GLC & $\begin{array}{l}\text { Relative } \\
\text { percent } \\
\text { difference }\end{array}$ \\
\hline Total withdrawals & 0.09 & 0.02 & -127 & 144.39 & 124.15 & -15 & 564.19 & 527.44 & -7 & 10.02 & 5.15 & -64 \\
\hline Public supply & .01 & .00 & -200 & 60.74 & 54.30 & -11 & 260.15 & 247.25 & -5 & 5.99 & 4.98 & -18 \\
\hline Domestic ${ }^{3}$ & .08 & .02 & -120 & 41.48 & 35.94 & -14 & NA & $\mathrm{NE}$ & NA & 3.28 & .02 & -198 \\
\hline Thermoelectric power & .00 & .00 & 0 & .27 & .27 & 0 & 4.07 & 4.11 & 1 & .11 & .12 & 9 \\
\hline Industrial $^{4}$ & .00 & .00 & 0 & 11.45 & 13.64 & -17 & 102.3 & 89.10 & -14 & .03 & .02 & -40 \\
\hline Irrigation $^{5}$ & NA & $\mathrm{NE}$ & NA & 26.88 & 15.67 & -53 & 197.67 & 186.98 & -6 & .01 & .01 & 0 \\
\hline \multirow[t]{2}{*}{ Livestock $^{6}$} & NA & $\mathrm{NE}$ & NA & 3.57 & 4.33 & -19 & NA & $\mathrm{NE}$ & NA & .60 & .00 & -200 \\
\hline & \multicolumn{3}{|c|}{ New York } & \multicolumn{3}{|c|}{ Ohio } & \multicolumn{3}{|c|}{ Pennsylvania } & \multicolumn{3}{|c|}{ Wisconsin } \\
\hline $\begin{array}{l}\text { Great Lakes Commission } \\
\text { water use category }\end{array}$ & USGS & GLC & $\begin{array}{c}\text { Relative } \\
\text { percent } \\
\text { difference }\end{array}$ & USGS & GLC & $\begin{array}{c}\text { Relative } \\
\text { percent } \\
\text { difference }\end{array}$ & USGS & GLC & $\begin{array}{c}\text { Relative } \\
\text { percent } \\
\text { difference }\end{array}$ & USGS & GLC & $\begin{array}{l}\text { Relative } \\
\text { percent } \\
\text { difference }\end{array}$ \\
\hline Total withdrawals & 119.04 & 133.88 & 12 & 102.36 & 143.70 & 34 & 7.65 & 6.23 & -20 & 273.91 & 184.88 & -39 \\
\hline Public supply & 27.78 & 44.89 & 47 & 33.56 & 38.12 & 13 & 2.25 & 1.85 & -20 & 69.44 & 67.58 & -3 \\
\hline Domestic $^{3}$ & 55.48 & 63.52 & 14 & 47.88 & 56.70 & 17 & 2.36 & 3.10 & 27 & 32.34 & 34.00 & 5 \\
\hline Thermoelectric power & .00 & .00 & 0 & .00 & .05 & 200 & .00 & .03 & 200 & 1.03 & .00 & -200 \\
\hline Industrial $^{4}$ & 13.20 & 11.99 & -10 & 14.83 & 35.54 & 82 & .13 & .04 & -106 & 24.72 & .00 & -200 \\
\hline Irrigation $^{5}$ & 6.39 & .15 & -191 & 4.06 & 2.89 & -34 & .14 & .01 & -173 & 109.60 & 42.70 & -88 \\
\hline Livestock $^{6}$ & 16.19 & 13.33 & -19 & 2.03 & 10.40 & 135 & 2.77 & 1.20 & -79 & 36.78 & 40.60 & 10 \\
\hline
\end{tabular}

'Great Lakes Commission (2006); as estimated for “All Facilities”; GLC “other” use may be included in USGS estimates; USGS estimates include those New York 8-digit HUC watersheds (0415930404150307) not included elsewhere in this report.

${ }^{2}$ U.S. Environmental Protection Agency (1989).

${ }^{3}$ Includes self-supplied residential, commercial, institutional use; for Pennsylvania and New York, does not include unreported withdrawals for commercial use.

${ }^{4}$ Includes manufacturing and mining use.

${ }^{5}$ Includes agriculture, landscape, and golf course use.

${ }^{6}$ Includes fish-hatchery and other aquaculture use. 
York (RPD of +92) and Ohio (RPD of -70) and for thermoelectric-power use estimated for Wisconsin (RPD of -56). For groundwater withdrawals, the most notable discrepancies are for irrigation and industrial use estimated for Wisconsin (RPD of -88 and +200 , respectively) and industrial use estimated for New York (RPD of +82$)$. Reasons for the discrepant estimates are uncertain. When the larger, more statistically robust basin-scale quantities are compared, then it is evident that the USGS and GLC estimates generally are in good agreement. Between estimates of both total withdrawals and total surfacewater withdrawals, the RPD is -10 ; between estimates of total groundwater withdrawals, the RPD is -8 . These discrepancies can be explained, in large part, by the unique characteristics of the USGS and GLC estimate sets used in the comparison.

\section{Data-Quality Summary and Suggested Improvements for Estimations of Use}

In summary, the USGS-determined estimates of withdrawals and other elements of Great Lakes Basin water use presented in this report can be used with reasonable confidence for water-resources planning and evaluations of large spatial scales of interest. That is, the estimates reasonably represent the relative differences in and quantities of water withdrawals and other elements of water use at the basin scale and, to a somewhat lesser extent, the Great Lakes watershed and Great Lakes State scale. As spatial scales of interest become increasingly smaller, particularly as one approaches HUC-scale or smaller evaluations, uncertainty associated with the withdrawal and other estimates could be of increasingly greater concern. Those categories of use for which withdrawal estimates for the basin, in part or entirety, are derived using non-site-specific data most typically pose the greatest concern to planning and resource evaluations at various spatial scales of interest, but particularly smaller scales. Those categories include domestic and livestock use - for which withdrawal estimates in all basin states presently (2005) are derived by using coefficient-based methods - as well as aquaculture, mining, irrigation, and industrial use - for which the estimates in one or more basin states are derived by using coefficientbased methods.

For the most part, those water users that potentially have the greatest impact on available water resources and related planning and evaluation - the largest water users (thermoelectric power, public supply, industry) — seemingly report a reasonably complete and accurate accounting of their water use. The apparent quality of withdrawal and other data made available by these users is attributable, in part, to various programs of regulatory and (or) public oversight. Additionally, the majority of states in the basin maintain either mandatory or well-developed voluntary water-use inventory programs that account for those uses.

The most comprehensive accounting of water withdrawals in basin states seems to be from Indiana, Minnesota, and Ohio. Through mandatory reporting requirements, these states inventory site-specific water withdrawals for almost all categories of water use (although possibly with varying QA and oversight of the reportings). The quality and completeness of the reported and (or) estimated water-use data by all basin states likely have improved over the past several decades. However, these improvements may have been constrained by variable budget support for the programs during this time. Improvements are driven, in part, by an increasing public awareness of the societal benefits of accurate accounting of present water use, as necessary to manage water resources in a sustainable manner.

Regardless of the scale of interest or level of waterresource planning and evaluations in the basin, the benefits - and in some cases, need - of continued improvements in the collection (measurement), availability (reporting), and methods for estimating water withdrawals and related use data for all categories of use should be evident. Likewise, it also should be evident that these estimations could benefit from improved methods of data analysis aimed at validating estimates and checking errors in measurement, estimation, reporting, and (or) tabulation of data. A notable challenge to improving the quality and reducing the uncertainty of withdrawal estimates in the basin seems to be improvement of the quality of those estimates representing typically unregulated use categories such as site-specific domestic and livestock use and to a lesser extent, irrigation use. In addition to limited regulatory oversight of their water use, these categories of use rely greatly on wells of relatively low pumping capacity that can be overlooked by inventory programs that focus on higher-capacity wells. As a consequence, there is a greater dependency on employing typically less accurate, coefficient-based methods for estimation of the water withdrawals associated with these uses. Although these uses collectively represent only about 4 percent or less of total withdrawals in the basin, improvements in the quality of their estimated withdrawals should help reduce uncertainty associated with applying these estimates to variously scaled water-resource evaluations in the basin, particularly local-scale evaluations. Domestic-use estimates could be well served by improved accounting of the public-supply and self-served domestic populations, particularly in regard to the geographic location of the served populations. Details on populations that are served by public water that is brokered through many water-supply companies distributed throughout various counties and HUCs are particularly wanting. All the coefficient-based estimation methods would seem to benefit from review and possible updating of the applied coefficients, particularly the per-capita use (demand) coefficients applied to estimation of domestic and livestock water use. In some applications, such as for livestock use, there seems to be a need for more standardization of those coefficients (regionalized climate-based), and in others, such as for domestic use, the need for more local variation (climate and (or) urban-rural based). Finally, with use of reclaimed wastewater possibly increasing in the basin in future years, there seems to be increasing need throughout the basin states for establishment and (or) substantial improvements in inventory programs for the collection and availability of water-reuse data. 


\section{Summary}

The USGS National Assessment of Water Availability and Use Program was asked by Congress to improve the ability to forecast water availability for future economic and environmental uses. With the Great Lakes Basin as a pilotstudy area, a principal objective of this effort is to improve the fundamental knowledge of the water balance of the basin, including the flows, storage, and water use by humans. This report contains estimates of water withdrawals in the basin during 2005, aggregated by 107 (of 111) 8-digit hydrologic (cataloging) units (HUCs) that constitute the United States part of the basin. Estimates of various associated elements of water use also are contained herein. The U.S. part of the basin encompasses parts of Lakes Superior, Michigan, Huron, Erie, and Ontario and their connecting channels, and it lies within eight states (Illinois, Indiana, Minnesota, Michigan, New York, Ohio, Pennsylvania, and Wisconsin). Understanding how water use, including withdrawals, varies categorically, spatially, and temporally is important to the overall analysis of water availability in the basin.

Water-withdrawal estimates are included for the following categories of use: public supply, self-supplied domestic, thermoelectric power, industrial, irrigation, mining, livestock, aquaculture, and reclaimed wastewater; and, in part, for commercial use. Estimates of associated elements of water use include, among others, intensity of withdrawals (water use), publicly supplied and self-supplied domestic populations, irrigated acres, and consumptive use. Also discussed are trends in water withdrawals during 1985-2005 and the uncertainty of withdrawals and associated water-use data and estimates, by category of use and source of the estimates, for each state.

Estimates of water withdrawals in the Great Lakes Basin indicate that about $30.3 \mathrm{Bgal} / \mathrm{d}$ was withdrawn for practically all categories of use in 2005. Less than 0.004 percent of the water withdrawn was saline, all of which was groundwater. Surface-water withdrawals totaled $28.8 \mathrm{Bgal} / \mathrm{d}$ or 95 percent of total withdrawals; about $24 \mathrm{Bgal} / \mathrm{d}$ was withdrawn from the Great Lakes or their connecting channels. Total withdrawals, and total surface-water withdrawals, have decreased 7 percent since 1995, generally following the withdrawal trends of industrial use and that of the largest use - thermoelectric power (76 percent of surface-water withdrawals in 2005). Groundwater withdrawals have increased 3 percent since 1995 and 33 percent since 1985. The substantial increase since 1985 primarily results from increases in irrigation and domesticsupply withdrawals. In 2005, public-supply, self-supplied domestic, and irrigation withdrawals accounted for 81 percent of groundwater withdrawals.

Gross per capita use in the basin (for all categories of use) was $1,320 \mathrm{gal} / \mathrm{d}$, compared to the high of $1,510 \mathrm{gal} / \mathrm{d}$ in 1990. The intensity of withdrawals (water use), measured as a function of land area, was $0.27 \mathrm{Mgal} / \mathrm{d} / \mathrm{mi}^{2}$. Estimates of consumptive use in the basin, based solely on withdrawals and application of representative coefficients of use, indicated total consumptive use of about 1,950 Mgal/d, or 6 percent of total withdrawals. Consumptive-use totals were the greatest, about 400-500 Mgal/d each, for public supply (excluding deliveries), irrigation, and thermoelectric power.

About 21.9 Bgal/d, or 72 percent of total withdrawals for 2005 , was used for thermoelectric-power generation. Essentially all of this water was derived from surface water and used for once-through cooling at powerplants. As such, the reuse potential of this water in the basin is high, with the majority of the withdrawn water returned to its surface-water source.

Public-supply withdrawals were $3.81 \mathrm{Bgal} / \mathrm{d}$ (13 percent of total withdrawals), with withdrawals declining by about 6 percent since 1985 and 13 percent since 1995. The population served by public supply increased about 5 percent from 1995 to 2005, suggesting more conservative use of water, more efficient distribution systems, and (or) reductions in deliveries to industrial users. About 77 percent of the population in the Great Lakes Basin obtained drinking water from public suppliers, compared to 83 percent in 1985 and 78 percent in 1995 . Surface water has consistently provided about 88 percent of the total withdrawals for public supply since 1985.

Self-supplied industrial withdrawals totaled $2.93 \mathrm{Bgal} / \mathrm{d}$, about 33 percent less than in 1985 and possibly as much as 30 percent less than in 1995. Surface water was the source for 95 percent of industrial withdrawals. Industrial withdrawals peaked during about $1965-70$ at $9 \mathrm{Bgal} / \mathrm{d}$, with the peak in industrial activity in the basin.

Combined withdrawals for mining, self-supplied domestic, irrigation, aquaculture, and livestock (in order of decreasing withdrawal rate) amounted to $1.63 \mathrm{Bgal} / \mathrm{d}$, or only 5 percent of total withdrawal. These combined withdrawals were distributed almost equally between surface-water and groundwater sources. Withdrawals in each of these categories, except livestock, increased almost continuously during 1985-2005. Mining withdrawals increased 103 percent and irrigation withdrawals 94 percent since 1985; livestock withdrawals decreased 26 percent from their peak in 1990. The number of irrigated acres for agriculture and golf courses, 750,000 in 2005 , increased continuously since 1985 , with an increase of 56 percent during this period. Associated with this increase in irrigated acreage is a 94-percent increase in irrigation withdrawals.

There appears to be virtually no use of reclaimed wastewater in the basin for industrial or irrigation applications; however, this assessment may be a function of the lack of available wastewater-reuse data. News media and other information sources suggest an increasing use of reclaimed wastewater in and near the basin in recent years. Although not accounted for by all states for 2005, self-supplied commercial withdrawals appear to represent only a fraction of total withdrawals in the basin. Past basin accountings (1995 and earlier) and available accountings from selected states for 2005 indicate that commercial withdrawals represent less than 1 percent of total withdrawals. Other studies indicate that commercial withdrawals may be somewhat underestimated because of accounting limitations. 
Within the Great Lakes Basin, the Lake Michigan watershed (39 percent of the basin land area) accounted for $15.0 \mathrm{Bgal} / \mathrm{d}$, or 49 percent, of total water withdrawals; an estimated $12.3 \mathrm{Bgal} / \mathrm{d}$ was withdrawn directly from Lake Michigan. The State of Michigan (51 percent of the basin land area) accounted for about 38 percent of total water withdrawals, representing the largest surface-water and groundwater withdrawals in the basin. Surface-water withdrawals primarily were for thermoelectric power, and groundwater withdrawals were primarily for public-supply and self-supplied domestic purposes. A disproportionately large percentage of surfacewater withdrawals (6 percent, $1.80 \mathrm{Bgal} / \mathrm{d}$ ) were in Illinois, given that this state represents less than 1 percent of the land area of the basin. Ninety percent of the Illinois population served by the water withdrawn from Lake Michigan for public supply resides outside the basin. Within land-based HUCs, the Lower Maumee (04100009) of Ohio accounted for the largest total withdrawal and total surface-water withdrawal (about $0.75 \mathrm{Bgal} / \mathrm{d}$ ). The St. Joseph (04050001) of Michigan and Indiana accounted for the largest total groundwater withdrawal (0.25 Bgal/d).

The largest thermoelectric-power, public-supply, and industrial withdrawals by HUC were directly from Lake Michigan; the largest mining withdrawals were directly from Lake Superior. For irrigation and self-supplied domestic, the largest withdrawals were from the St. Joseph; for aquaculture, the Boardman-Charlevoix (04060105); and for livestock, the Manitowoc (04030101) and St. Joseph.

The degree of uncertainty associated with estimates of water withdrawal varies by state and by category of use. Reported site-specific withdrawal data generally are available for major users, including thermoelectric-power, public-supply, and industrial users. Estimates for domestic and livestock withdrawals typically are derived at the county level by use of coefficients, population and (or) other data, then reapportioned at the watershed level on the basis of the percentage of the land area of a watershed within a county. The least uncertainty may be associated with withdrawal estimates for thermoelectric power and public supply; often these withdrawals are directly or indirectly measured and publicly reported by the facility. The greatest uncertainty might be associated with self-supplied domestic withdrawal estimates, because most withdrawals are estimated from per capita use coefficients and uncertain estimates of population served.

\section{References Cited}

American Water Works Association, 2008, Water reuse rates and charges, survey results: 24 p., accessed August 25, 2009, at http://www.awwa.org/files/Resources/Waterwiser/ references/PDFs/AWWAWaterReusePaperSept2008.pdf

Andreson, J., Moen, T., Ritchie, J., Baer, B., Johnson, J., Savona, C., Swartz, M., and Van Til, R., 2000, Estimated water use for agriculture irrigation in Michigan 1997-1999: Michigan Department of Agriculture, Michigan State University, Michigan Department of Environmental Quality, unpublished report [variously paged].

Arihood, L.D., 2009, Processing, analysis, and general evaluation of well-driller logs for estimating hydrogeologic parameters of the glacial sediments in a ground-water flow model of the Lake Michigan Basin: U.S. Geological Survey Scientific Investigations Report 2008-5184, 26 p.

Avery, Charles, 1999, Estimated water withdrawals and use in Illinois, 1992: U.S. Geological Survey Open-File Report 99-97, 49 p.

Bozek, C.R., 2002, A towering challenge: ElectricPerspectives, v. 27, no. 1, accessed December 18, 2003, at http:// www.eei./magazine/editorial_content/nonav_stories/200201-01-tower.htm

City-Data Forum, 2007, The Great Lakes-Industrial wasteland or national treasure?: Accessed April 11, 2008, at http://www.city-data.com/forum/general-u-s/211055-greatlakes-industrial-wasteland-natural-treasure.html

Coon, W.F., and Sheets, R.A., 2006, Estimate of ground water in storage in the Great Lakes Basin, United States, 2006: U.S. Geological Survey Scientific Investigations Report 2006-5180, 19 p.

Coordinating Committee on Great Lakes Basic Hydraulic and Hydrologic Data, 1977, Coordinated Great Lakes physical data: Accessed February 13, 2008, at http://www.lre. usace.army.mil/_kd/Items/actions.cfm?action=Show\&item_ $i d=3566 \&$ destination $=$ ShowItem

Council of Great Lakes Governors, 2001, The Great Lakes Charter Annex: Accessed December 6, 2007, at http://www. cglg.org/projects/water/docs/GreatLakesCharterAnnex.pdf

Dziegielewski, Ben, and Bik, Thomas, 2006, Water use benchmarks for thermoelectric power generation, project completion report: Accessed August 26, 2009, at http://www.geog. siu.edu/geography_info/research/documents/ThermoReport. $p d f$ 
Encyclopedia of Cleveland History, 2003, Rock salt: Cleveland, Ohio, Case Western Reserve University and the Western Reserve Historical Society, accessed April 28, 2009, at http://ech.cwru.edu/ech-cgi/article.pl?id=RS6

Friends of the St. Joe River Watershed, 2009, About the watershed: Accessed April 6, 2009, at http://www.stjoeriver.net/ about.htm

Grannemann, N.G., Hunt, R.J., Nicholas, J.R., Reilly, T.E., and Winter, T.C., 2000, The importance of ground water in the Great Lakes Region: U.S. Geological Survey WaterResources Investigations Report 00-4008, 14 p.

Grannemann, N.G., and Reeves, H.W., 2005, Great Lakes Basin water availability and use-A study of the National Assessment of Water Availability and Use Program: U.S. Geological Survey Fact Sheet 2005-3113, 4 p.

Great Lakes Commission, 2003, Toward a water resources management decision support system for the Great LakesSt. Lawrence River Basin - Status of data and information on water resources, water use, and related ecological impacts: Ann Arbor, Mich., 142 p.

Great Lakes Commission, 2006, Annual report of the Great Lakes regional water use database repository representing 2004 water use data in gallons: Accessed January 8, 2006, at http://www.glc.org/wateruse/database/pdf/2004-gallons.pdf

Great Lakes Commission, 2009, Annual report of the Great Lakes regional water use database repository representing 2005 water use data in gallons: Accessed December 3, 2009, at http://glc.org/wateruse/database/pdf/2005\%20 Water\%20Use\%20Report.pdf

Great Lakes Information Network, 2008, People in the Great Lakes region: Accessed February 24, 2008, at http://www. great-lakes.net/envt/flora-fauna/people.html

Horn, M.A.; Moore, R.B.; Hayes, Laura; and Flanagan, S.M., 2008, Methods for and estimates of 2003 projected water use in the Seacoast region, southeastern New Hampshire: U.S. Geological Survey Scientific Investigations Report 2007-5157, $87 \mathrm{p}$.

Hough, J.L., 1958, Geology of the Great Lakes: Urbana, Ill., University of Illinois Press, $313 \mathrm{p}$.

Hutson, S.S., 2007, Guidelines for preparation of State wateruse estimates for 2005: U.S. Geological Survey Techniques and Methods 4-E1, 28 p., accessed November 26, 2007, at http://pubs.usgs.gov/tm/2007/tm4e1/pdf/tm4-e1.pdf

Hutson, S.S., Barber, N.L., Kenny, J.F., Linsey, K.S., Lumia, D.S., and Maupin, M.A., 2004, Estimated use of water in the United States in 2000: U.S. Geological Survey Circular $1268,46 \mathrm{p}$.
Imperial Valley Water Authority, 2007, Agricultural irrigation use data: Accessed November 29, 2007, at $h t t p: / / w w w$. outfitters.com/ ivwa/Agricul.html

Injerd, Daniel, 2005, Annex 2001-An update: Presentation from the conference Straddling the Divide-Water Supply Planning in the Lake Michigan Region, Chicago, Ill., February 15-16, 2005, accessed December 3, 2007, at http://www. nipc.org/environment/slmrwsc/conferences/1C_Injerd.pdf

International Joint Commission, 2000, Protection of the waters of the Great Lakes-Final report to the governments of Canada and the United States: Accessed February 13, 2008, at $h t t p: / / w w w . i j c . o r g / p h p / p u b l i c a t i o n s / h t m l /$ finalreport.html

Kenny, J.F., Barber, N.L., Hutson, S.S., Linsey, K.S., Lovelace, J.K., and Maupin, M.A., 2009, Estimated use of water in the United States in 2005: U.S. Geological Survey Circular 1344, 52 p.

Kosin, Phil, 2007, Taking a tough look at golf industryBloom is off rose for golf; courses face adversity: Chicagoland Golf, October 2007, accessed April 15, 2008, at http://www.chicagolandgolf.com/toughlookgolfindustry. html

Lovelace, J.K., 2009a, Methods for estimating water withdrawals for aquaculture in the United States, 2005: U.S. Geological Survey Scientific Investigations Report 2009$5042,13 \mathrm{p}$.

Lovelace, J.K., 2009b, Methods for estimating water withdrawals for mining in the United States, 2005: U.S. Geological Survey Scientific Investigations Report 20095053, 7 p.

Lovelace, J.K., 2009c, Method for estimating water withdrawals for livestock in the United States, 2005: U.S. Geological Survey Scientific Investigations Report 2009-5041, 7 p.

MacKichan, K.A., 1951, Estimated use of water in the United States, 1950: U.S. Geological Survey Circular 115, 13 p.

MacKichan, K.A., 1957, Estimated use of water in the United States, 1955: U.S. Geological Survey Circular 398, 18 p.

MacKichan, K.A., and Kammerer, J.C., 1961, Estimated use of water in the United States, 1960: U.S. Geological Survey Circular 456, $26 \mathrm{p}$.

Meng, Yi; Luo, Shihui; and Huang, Feng, 2007, Water reuseAn integral part of sustainable water resource planning: Presentation to the NE Illinois Regional Water Supply Planning Group, June 26, 2007, accessed August 26, 2009, at http:// www.chicagoareaplanning.org/watersupply/documents/ presentations/2007-06-26_water_reuse.pdf 
Micheletti, W.C., and Burns, J.M., 2002, Emerging issues and needs in power plant cooling systems in Proceedings of the workshop on Electric Utilities and Water-Emerging Issues and R\&D Needs, Pittsburgh, Pennsylvania, July 23-24, 2002: 14 p., accessed April 27, 2009, at http://www.netl.doe. gov/publications/proceedings/02/EUW/Micheletti_JMB. $P D F$

Michigan Department of Environmental Quality, 1994, Salt_A Michigan resource: 2 p., accessed April 28, 2009, at http://www.deq.state.mi.us/documents/deq-ogs-gimdlGGSB.pdf

Michigan Department of Environmental Quality, 2005, Water withdrawals for golf course irrigation in Michigan in 2004: 9 p., accessed September 17, 2008, at http://www.deq.state. mi.us/documents/deq-wd-wurp-golf04.pdf

Michigan Sea Grant Program, 1985, The Great Lakes, an environmental atlas and resource book: Michigan Sea Grant Extension Bulletins E-1866-70, 5 sheets.

Miller, J.A., ed., 2000, Ground water atlas of the United States: U.S. Geological Survey [variously paged].

Morikawa, Mari; Morrison, Jason; and Gleick, Peter, 2007, Corporate reporting on water-A review of eleven global industries: Oakland, Calif., Pacific Institute [variously paged], accessed August 26, 2009, at http://www.pacinst. org/reports/water_reporting/corporate_reporting_on_water. $p d f$

Multi-Resolution Land Characteristics Consortium, 2003, National Land Cover Database: Accessed January 31, 2008, at http://www.mrlc.gov/

Murray, C.R., 1968, Estimated use of water in the United States, 1965: U.S. Geological Survey Circular 556, 53 p.

Murray, C.R., and Reeves, E.B., 1972, Estimated use of water in the United States in 1970: U.S. Geological Survey Circu$\operatorname{lar} 676,37 \mathrm{p}$.

Murray, C.R., and Reeves, E.B., 1977, Estimated use of water in the United States in 1975: U.S. Geological Survey Circu$\operatorname{lar} 765,39 \mathrm{p}$.

Muskegon County Wastewater Management System, 2009, Treatment system: Accessed November 3, 2009, at http:// www.muskegoncountywastewater.com/treatmentservice. shtml

National Oceanic and Atmospheric Administration, 2007, U.S. climate at a glance: National Climatic Data Center, accessed November 27, 2007, at http://www.ncdc.noaa.gov/ oa/climate/research/cag3/cag3.html
National Oceanic and Atmospheric Administration, 2009, Land cover data sets for the Great Lakes region-Change Analysis Program (C-CAP): Accessed March 3, 2009, at http://www.csc.noaa.gov/crs/lca/ccap.html and http://www. csc.noaa.gov/crs/lca/tech_cls.html

Natural Resources Canada, 2003, Welcome to GeoGratis: Accessed February 14, 2008, at http://geogratis.cgdi.gc.ca/ geogratis/en/index.html

Natural Resources Conservation Service, 2008, Watershed Boundary Dataset (WBD): Accessed April 7, 2008, at http:// www.ncgc.nrcs.usda.gov/products/datasets/watershed/

Neff, B.P., and Killian, J.R., 2003, The Great Lakes water balance - Data availability and annotated bibliography of selected references: U.S. Geological Survey WaterResources Investigations Report 02-4296, 37 p.

Neff, B. P., and Nicholas, J.R., 2005, Uncertainty in the Great Lakes water balance: U.S. Geological Survey Scientific Investigations Report 2004-5100, 42 p.

Neff, B.P., Piggott, A.R., and Sheets, R.A., 2006, Estimation of shallow ground-water recharge in the Great Lakes Basin: U.S. Geological Survey Scientific Investigations Report 2005-5284, 20 p.

Northeastern Illinois Regional Water Supply Planning Group, 2009, October newsletter: Chicago Metropolitan Agency for Planning, accessed August 26, 2009, at http://www.cmap. illinois.gov/OctoberNewsletter.aspx

Sanford, K.F., 1995, Solution salt mining in New York [abs], presentation from joint meeting of New York State Geological Association and Eastern Section-American Association of Petroleum Geologists, October 1995: New York State Department of Environmental Conservation, accessed April 28, 2009, at http://www.dec.ny.gov/energy/1558.html

Office of Management and Budget, 1987, Standard industrial classification manual: Washington, D.C., U.S. Government Printing Office, $705 \mathrm{p}$.

Pebbles, Victoria, 2003a, Measuring and estimating consumptive use of the Great Lakes water: Ann Arbor, Mich., Great Lakes Commission, 18 p., accessed August 27, 2009, at http://www.glc.org/wateruse/wrmdss/finalreport/pdf/CU Briefing.pdf

Pebbles, Victoria, 2003b, Consumptive use in the Great lakes region and basin-Annotated bibliography of selected references: Ann Arbor, Mich., Great Lakes Commission, 11 p., accessed August 27, 2009, at http://www.glc.org/wateruse/ wrmdss/finalreport/pdf/CU_biblio.pdf

Seaber, P.R., Kapinos, F.P., and Knapp, G.L., 1987, Hydrologic unit maps: U.S. Geological Survey Water-Supply Paper 2294, 63 p. 
Shaffer, K.H., 2009, Variations in withdrawal, return flow, and consumptive use of water in Ohio and Indiana, with selected data from Wisconsin, 1999-2004: U.S. Geological Survey Scientific Investigations Report 2009-5096, 93 p.

Shaffer, K.H., and Runkle, D.L., 2007, Consumptive water-use coefficients for the Great Lakes Basin and climatically similar areas: U.S. Geological Survey Scientific Investigations Report 2007-5197, $191 \mathrm{p}$.

Sheets, R.A., and Simonson, L.A., 2006, Compilation of regional ground-water divides for principal aquifers corresponding to the Great Lakes Basin, United States: U.S. Geological Survey Scientific Investigations Report 2006-5102, 23 p.

Solley, W.B., Chase, E.B., and Mann, W.B., IV, 1983, Estimated use of water in the United States in 1980: U.S. Geological Survey Circular 1001, 56 p.

Solley, W.B., Merk, C.F., and Pierce, R.R., 1988, Estimated use of water in the United States in 1985: U.S. Geological Survey Circular 1004, 82 p.

Solley, W.B., Pierce, R.R., and Perlman, H.A., 1993, Estimated use of water in the United States in 1990: U.S. Geological Survey Circular 1081, 76 p.

Solley, W.B., Pierce, R.R., and Perlman, H.A., 1998, Estimated use of water in the United States in 1995: U.S. Geological Survey Circular 1200, 71 p.

University of Wisconsin Sea Grant Institute, 2004, Aquaculture: Accessed April 16, 2009, at http://www.seagrant.wisc. edu/aquaculture/

U.S. Congress, 1972, Amendments to the Federal Water Pollution Control Act of 1972, Public Law 92-500, Title 33, Chapter 26, subchapter III, Section 1326 (a) and 1326 (b) [Thermal discharges]: Accessed April 27, 2009, at http:// www4.law.cornell.edu/uscode/33/1326.html

U.S. Congress, 1977, Clean Water Act of 1977, Public Law 92-217, Title 33, Chapter 26, subchapter I, Section 1251: Accessed April 27, 2009, at http://www4.law.cornell.edu/ uscode/33/1251.html

U.S. Department of Agriculture, National Agricultural Statistics Service, 2007, 2002 Census of agriculture, volume 1, county level data: Accessed November 30, 2007, at http:// www.nass.usda.gov/census/census02/volume1/index2.htm

U.S. Department of Agriculture, National Agricultural Statistics Service, 2008a, 2002 Census of agriculture, volume 1, geographic area series, farm and ranch irrigation survey: Accessed February 12, 2008, at http://www.nass.usda.gov/ Census/Create_Census_FRIS.jsp
U.S. Department of Agriculture, National Agricultural Statistics Service, 2008b, 2005 Census of aquaculture: Accessed February 12, 2008, at http://www.agcensus.usda.gov/ Publications/2002/Aquaculture/index.asp

U.S. Department of Agriculture, National Agricultural Statistics Service, 2009a, 2002 Census of agriculture, 2002 Census publications, Census quick stats 2.0 beta: Accessed April 3, 2009, at http://www.agcensus.usda.gov/ Publications/2002/

U.S. Department of Agriculture, National Agricultural Statistics Service, 2009b, 2002 Census of agriculture, 2002 Census publications, $\mathrm{Ag}$ atlas maps, livestock and animals: Accessed April 3, 2009, at http://www.agcensus.usda.gov/ Publications/2002/Ag_Atlas_Maps/Livestock_and_Animals/ index.asp

U.S. Department of Commerce, U.S. Census Bureau, 1992, Census of population and housing, 1990, summary social, economic, and housing characteristics: U.S. Bureau of the Census 1990 CPH-5-16, 314 p., apps.

U.S. Department of Commerce, U.S. Census Bureau, 2001, United States Census 2000: Accessed August 16, 2007, at http://www.census.gov/main/www/cen2000.html

U.S. Department of Commerce, U.S. Census Bureau, 2005, Table 1. Annual estimates of the population of metropolitan and micropolitan statistical areas-April 1, 2000 to July 1, 2005: Accessed February 7, 2008, at http://www.census.gov/ population/www/estimates/metropop/2005/cbsa-01-fmt.xls

U.S. Department of Commerce, U.S. Census Bureau, 2006, County population and estimated components of population change, all counties: April 1, 2000 to July 1, 2005, accessed March 21, 2006, at http://www.census.gov/popest/datasets. html

U.S. Department of Energy, Energy Information Administration, 2007, Energy Information Administration glossary: Accessed November 29, 2007, at http://www.eia.doe.gov/ glossary/glossary_n.htm

U.S. Department of Energy, Energy Information Administration, 2008a, Form EIA-767 database: Accessed February 12, 2008, at http://www.eia.doe.gov/cneaf/electricity/page/ eia767.html

U.S. Department of Energy, Energy Information Administration, 2008b, Form EIA-906 and EIA-920 databases: Accessed February 12, 2008, at http://www.eia.doe.gov/ cneaf/electricity/page/eia906_920.html

U.S. Environmental Protection Agency, 1989, Preparing perfect project plans - Pocket guide for preparation of quality assurance project plans: U.S. Environmental Protection Agency, EPA/600/9-89/087, 62 p. 
U.S. Environmental Protection Agency, 2004, Public access to information \& public involvement: Office of Water, EPA 816-F-04-039, 3 p., accessed August 30, 2009, at http:// www.epa.gov/safewater/sdwa/pdfs/fs_30ann_publicinvolve web.pdf

U.S. Environmental Protection Agency, 2006a, References for Great Lakes statistics: Accessed February 21, 2008, at http://www.epa.gov/glnpo/statsrefs.html

U.S. Environmental Protection Agency, 2006b, Senate Committee report on S.1316 Report 104-169, Section 24. Definitions: Accessed March 29, 2008, at http://www.epa.gov/ OGWDW/guide/sen104.html

U.S. Environmental Protection Agency, 2007, Safe drinking water information system (SDWIS), query form, search the SDWIS database: Accessed February 12, 2008, at http:// www.epa.gov/enviro/html/sdwis/sdwis_query.html
U.S. Geological Survey, 2007, Hydrologic unit maps-What are hydrologic units?: Accessed February, 11, 2008, at http://water.usgs.gov/GIS/huc.html

U.S. Geological Survey, 2009, Water use in the United States: Accessed October 31, 2009, at http://water.usgs.gov/watuse/

Washington State Department of Ecology, 2005, Frequently asked questions about reclaimed water use: 10 p., accessed December 3, 2007, at http://www.ecy.wa.gov/pubs/0510012. $p d f$

Wilcox, D.A., Thompson, T.A., Booth, R.K., and Nicholas, J.R., 2007, Lake-level variability and water availability in the Great Lakes: U.S. Geological Survey Circular 1311, $25 \mathrm{p}$. 


\section{Glossary}

Water-use terminology has changed over time in the series of USGS circulars on water use (MacKichan, 1951, 1957; MacKichan and Kammerer, 1961; Murray, 1968; Murray and Reeves, 1972, 1977; Solley and others, 1983, 1988, 1993, 1998; Hutson and others, 2004; and Kenny and others, 2009). For the 1950 and 1955 circulars, water use was defined only as water withdrawals. In the 1960 circular, the term was redefined to include consumptive use of water as well as withdrawals. With the beginning of the USGS NWUIP in 1978, the term was again redefined to include return flow and offstream and instream uses. In the 1985 circular, the term was redefined to include withdrawals plus deliveries from public suppliers. For the 2000 circular, the definition of water use returned to that in the earliest reports: water withdrawals. For the 2005 circular, on which this report on water use in the Great Lakes Basin is based, water use is defined as withdrawals plus deliveries from public suppliers to domestic (residential) users. The following terms are referenced in this report and also can be found in the more extensive glossary of terms in the water-use circulars.

\section{A}

animal-specialties water use Water use associated with the production of fish in captivity, except for fish hatcheries, and the raising of horses and such fur-bearing animals, as rabbits and pets. Animal-specialties water-use estimates were included in some previous water-use circulars but were combined with the livestock or aquaculture categories for 2000 and 2005. See also aquaculture water use, fish-farm water use, livestock water use, and rural water use.

aquaculture water use Water use associated with the farming of organisms that live in water - such as finfish and shellfish - and offstream water use associated with fish hatcheries. See also fish-farm water use, fish-hatchery water use, animal-specialties water use, and livestock water use.

\section{B}

blowdown The continuous or intermittent discharge, or purging, of a small amount of circulating water, such as in a boiler. Blowdown normally is expressed as a percentage of the water being circulated. Its purpose is to prevent an increase in the concentration of solids in the water due to evaporation. See also evaporation.

\section{C}

commercial water use Water for motels, hotels, restaurants, office buildings, other commercial facilities, military and nonmilitary institutions - and in water-use circulars for 1990 and 1995, water for offstream fish hatcheries. Water may be obtained from a public-supply system or may be self-supplied. Commercial water-use estimates were included in some previous water-use circulars but were omitted for 2000 and 2005; available estimates from reporting states are included in this report. See also fish-hatchery water use, public-supply water use, public-supply deliveries, and self-supplied water use.

consumptive use The part of water withdrawn [for a particular use] that is evaporated, transpired, incorporated into products or crops, consumed by humans or livestock, or otherwise removed from the immediate water environment. Consumptive use estimates were included in some previous water-use circulars but were omitted for 2000 and 2005 . Also referred to as "water consumed."

conveyance loss Water lost in transit from a pipe, canal, conduit, or ditch by leakage or evaporation (a negative conveyance loss). Generally, the water is not available for further use; however, leakage from an irrigation ditch, for example, may percolate to a groundwater source and be available for further use. Also represents water that infiltrates a distribution system and is usually water from a high water table (a positive conveyance loss). Conveyance-loss estimates were included in some previous water-use circulars but were omitted for 2000 and 2005. See also evaporation and irrigation water use. 
cooling system An equipment system that provides water for cooling purposes, such as to condensers at powerplants or at factories, and includes water intakes and outlets; cooling towers; and ponds, pumps, and pipes. Cooling systems are designated by one of two principal types (designs), which are delineated on the basis of whether or not water used in the system as steam to drive power-generating turbines and to cool condensers is recycled (recirculated) and measures are taken to reduce the temperature of the heated water. See closed-loop cooling systems and oncethrough cooling systems.

closed-loop Cooling systems where water is withdrawn from a source, circulated through heat exchangers, then cooled, and recycled. A cooling pond (a shallow reservoir with a large surface area) or cooling tower (into which heated water is sprayed and then cooled by evaporation) may be used to reduce the heat of water circulated through heat exchangers. Subsequent water withdrawals are used to replace water lost to evaporation, blowdown, drift, and leakage and, accordingly, results in a much smaller return flow than once-through cooling. This type of cooling-system typically uses less water than a oncethrough system, but has a higher percentage of consumptive use (evaporation), typically greater than 60 percent (Solley and others, 1998). See also cooling system, cooling-system type, once-through cooling system, industrial water use, and thermoelectric-power water use. See also cooling system and evaporation.

once-through Cooling systems in which the water is withdrawn from a source, circulated through heat exchangers, and then returned to a body of water at a higher temperature. Water is used only one time in the turbine-driving and condenser-cooling processes before it is returned to the water source. The water source typically is a river or large lake or reservoir. Once-through cooling systems may be referred to as open-loop systems. Although once-through cooling requires substantial water withdrawals, the consumption is low-usually less than 3 percent (Solley and others, 1998). See also cooling system, cooling system type, closed-loop cooling system, industrial water use, and thermoelectric-power water use. See also cooling system.

\section{D}

domestic water use Water used for all such indoor household purposes as drinking, food preparation, bathing, washing clothes and dishes, flushing toilets, and such outdoor purposes as watering lawns and gardens. Term used in water-use circulars before 2000 to describe the combined public-supply deliveries to domestic (residential) users and self-supplied domestic withdrawals. For 2000 and 2005, domestic water use refers only to self-supplied domestic withdrawals. See also public-supply deliveries, public-supply water use, rural water use, and self-supplied water use.

drift Fine water droplets blown out of a cooling tower along with exhaust air, usually expressed as a percentage of water circulated.

\section{E}

elements of use Those data that detail the various aspects water use. Includes the components of the water cycle from removal of water from its source to its disposal, the factors that may contribute to water use, and indicators of the extent of water use. For the USGS National Water Use Inventory Program, estimation of the quantities of certain elements of use is considered mandatory. For the 2005 compilation for counties and watersheds designated by 8 -digit hydrologic (cataloging) unit code, these elements included self-supplied withdrawals for all categories of use by source (surface water and groundwater) and type (freshwater and saline) of water; reclaimed wastewater (for irrigation and industrial use); total population; population served by public supply; public-supply deliveries for domestic use; self-supplied domestic population; withdrawals by cooling-system type (once-through and closed-loop) and power generated for thermoelectric power; and irrigated acreage by type of irrigation (sprinkler, microirrigation, and surface). Estimates for each of these elements are presented in this study. Other elements for 
which estimates are presented include land acreage (basin, watershed, and state), intensity of withdrawals, gross per capita use, and application rate for irrigated lands.

evaporation The change of water from a liquid form into a vapor state, such as water evaporating from pools, large bodies of water, and runoff from car-washing or irrigation systems; also includes evaporation through dehumidifiers and from heating and cooling processes in industrial facilities and thermoelectric powerplants. See also evapotranspiration and transpiration.

evapotranspiration A collective term used to include water discharged to the atmosphere as a result of plant transpiration and evaporation from soil and surface-water bodies. See also evaporation and transpiration.

\section{$\mathbf{F}$}

fish-farm water use Water used for the production of finfish and shellfish under controlled feeding, sanitation, and harvesting procedures for commercial purposes. Water use by fish farms is classified in the aquaculture category. See also animal-specialties water use, aquaculture water use, and fish-hatchery water use.

fish-hatchery water use Water used for raising fish for later release and in association with the operation of fish hatcheries or fishing preserves. Fish-hatchery water use is classified in the aquaculture category. See also aquaculture water use, commercial water use, and fish-farm water use.

freshwater Water that contains less than 1,000 milligrams per liter $(\mathrm{mg} / \mathrm{L})$ of dissolved solids; generally, more than $500 \mathrm{mg} / \mathrm{L}$ of dissolved solids is undesirable for drinking and many industrial uses. For 2005, the dissolvedsolids limit does not define freshwater for public-water supply use; for this use, freshwater is considered water that does not require desalination or dilution to make it potable. See also saline water.

\section{G}

gigawatt-hour (GWh) An electrical energy unit of measure equal to $1,000,000$ watts of power supplied to, or taken from, an electric circuit steadily for 1 hour.
Great Lakes Basin In a general sense, watersheds within eight states of the United States (Illinois, Indiana, Michigan, Minnesota, New York, Ohio, Pennsylvania, Wisconsin) and two Canadian provinces (Ontario and Quebec) that directly or indirectly drain surface water or streamflow to one or more of the five Great Lakes (Erie, Huron, Michigan, Ontario, Superior). In this report, Great Lakes Basin water-use data are limited to the United States part of 107 watersheds described by 8-digit hydrologic unit codes (HUCs).

Great Lakes watershed Combination of individual watersheds cataloged by 8 -digit hydrologic (cataloging) unit codes (HUCs) that directly or indirectly drain surface water or streamflow to one of the five Great Lakes (Erie, Huron, Michigan, Ontario, Superior). In this report, Great Lakes watershed water-use data are limited to the United States part of 107 watersheds described by HUCs.

gross per capita use For this report, an indicator of intensity of water use, measured as a function of population. Includes total water withdrawals by all categories of use and total population, expressed as the average amount of water used per person during the standard time period of a day, in gallons per day per person. Gross per capita use is not an accounting of that amount of water specifically used by individuals for purposes such as drinking and other domestic activities. That amount is often termed simply "per capita use."

\section{H}

hydroelectric-power use The use of water in the generation of electricity at plants where the turbine generators are driven by falling water. Hydroelectric use is classified as an instream use. See also instream use.

hydrologic unit codes Hydrologic divisions and subdivisions of the United States in a hierarchy of successively smaller hydrologic units, which are classified into four levels: regions, sub-regions, accounting units, and cataloging units. The hydrologic units are arranged within each other, from the smallest (cataloging units) to the largest (regions). Each hydrologic unit is identified by a unique hydrologic unit code consisting of two to eight digits based on the four levels of classification in the hydrologic unit system. The 
fourth level of classification is the 8-digit cataloging unit (HUC, in this report), the smallest element in the hierarchy of hydrologic units considered in this report. A cataloging unit is a geographic area representing part of all of a surface drainage basin, a combination of drainage basins, or a distinct hydrologic feature. There are 2,264 cataloging units in the Nation and 111 in the Great Lakes Basin, four of which drain into Canada and are not fully considered in this report. Cataloging units sometimes are called watersheds, as they are in selected applications this report.

\section{I}

industrial water use Water used for fabrication, processing, washing, and cooling, and includes such industries as chemical and allied products, food, mining, paper and allied products, petroleum refining, and steel. Term used in water-use circulars before 2000 to describe the combined public-supply deliveries to industrial users and self-supplied industrial withdrawals. For 2000 and 2005, industrial water use refers only to selfsupplied industrial withdrawals. See also cooling system, cooling-system type, mining water use, public-supply deliveries, publicsupply water use, self-supplied water use, and thermoelectric-power water use.

instream water use Water used, but not withdrawn, from a surface-water source for such purposes as hydroelectric-power generation, navigation, water-quality improvement, fish propagation, biodiversity and habitat protection, and recreation. Instream wateruse estimates for hydroelectric power were included in water-use circulars before 2000 .

intensity of withdrawals For this report, an indicator of intensity of water use, measured as a function of land area. Includes total water withdrawals by all categories of use and total land area, expressed as the average amount of water withdrawn within the standard area of a square mile, in gallons per day per square mile.

irrigation water use Water applied by an irrigation system to assist in the growing of crops, horticulture, and pastures or to maintain vegetative growth in recreational lands such as parks and golf courses. Irrigation includes water applied for pre-irrigation, frost protection, chemical application, weed control, field preparation, crop cooling, harvesting, dust suppression, leaching of salts from the root zone, and water lost in conveyance. See also conveyance loss, and irrigation systems: microirrigation, sprinkler, and surface.

irrigation systems Equipment used to distribute water to crops or other irrigated lands. Irrigation systems are grouped into the following three broad categories:

microirrigation A system that wets only a discrete portion of the soil surface in the vicinity of the plant by means of applicators operated under low pressure. The applicators can be placed on or below the surface of the ground or can be suspended from supports. Subsurface systems that control the height of the water table are included in this category. See also irrigation water use, sprinkler irrigation system, and surface irrigation system.

sprinkler A system in which water is applied by means of perforated pipes or nozzles operated under pressure as to form a spray pattern. See also irrigation water use, microirrigation, and surface irrigation.

surface A system by which water is distributed by flood, furrow, or gravity. Flood irrigation applies ponded water to the entire soil surface. Furrow irrigation uses furrows or rows to distribute water and restrict ponding to design locations and capacities. Gravity irrigation distributes water by gravity, not pumping, through networks of ditches or pipes. See also irrigation water use, microirrigation, and sprinkler irrigation.

J

K

L

livestock water use Water for livestock watering, feedlots, dairy operations, and other on-farm needs. Types of livestock include dairy cows and heifers, beef cattle and calves, sheep and lambs, goats, hogs and pigs, horses, and poultry. See also animal-specialties 
water use, aquaculture water use, and rural water use.

\section{M}

mining water use Water used for the extraction of naturally occurring minerals including solids, such as coal, sand, gravel, and other ores; liquids, such as crude petroleum; and gases, such as natural gas. Also includes uses associated with quarrying, milling, and other preparations customarily done at the mine site or as part of a mining activity. Does not include water associated with dewatering of the aquifer that is not put to beneficial use. Also does not include water used in processing, such as smelting, refining petroleum, or slurry pipeline operations. These processing uses are included in industrial water use. See also industrial water use and self-supplied water use.

\section{$\mathbf{N}$ \\ 0}

offstream water use Water withdrawn or diverted from a groundwater or surface-water source for aquaculture, commercial, domestic self-supply, industrial, irrigation, livestock, mining, public supply, thermoelectric power, and other uses. See also entries for each of the previously mentioned uses.

\section{$\mathbf{P}$}

public-supply deliveries Amount of water delivered from a public supplier to users for domestic (residential), commercial, industrial, thermoelectric-power, irrigation or public-use purposes. Delivery estimates were included in some water-use circulars before 2000 but were omitted for 2000; deliveries to domestic users are included in the circular for 2005. See also commercial water use, domestic water use, industrial water use, thermoelectric-power water use, public-supply water use, and public water use.

public-supply water use Water withdrawn by public and private water suppliers that furnish water to at least 25 people or have a minimum of 15 connections. Public suppliers provide water for a variety of uses, such as domestic, commercial, industrial, thermoelectric-power, and public water use.
See also commercial water use, domestic water use, industrial water use, thermoelectric-power water use, public-supply deliveries, and public water use.

public water use Water supplied from a public supplier and used for such purposes as firefighting, street washing, flushing of water lines, and maintaining municipal parks and swimming pools. Generally, public-use water is not billed by the public supplier. See also public-supply deliveries, and public-supply water use.

\section{$\mathbf{0}$}

$\mathbf{R}$

reclaimed wastewater Wastewater-treatment-plant effluent that has been diverted for beneficial use before it reaches a natural waterway or aquifer. Term used in previous water-use circulars. See also water use.

return flow Water that reaches a groundwater or surface-water source after release from the point of use and thus becomes available for further use. Return flow may be from industries, wastewater treatment plants, and other, often large, water users. Term used in previous water-use circulars. See also wastewater returns and water use.

rural water use Water used in suburban or farm areas for domestic and livestock needs. The water generally is self-supplied and includes domestic use, drinking water for livestock, and other uses such as dairy sanitation, cleaning, and waste disposal. Term used in previous water-use circulars. See also animal-specialties water use, domestic water use, livestock water use, and self-supplied water use.

\section{S}

saline water use Use of water that contains $1,000 \mathrm{mg} / \mathrm{L}$, or more, of dissolved solids.

Term used in previous water-use circulars. For 2005, water for public-supply use that requires desalination or dilution to make it potable is considered saline water. Generally, more than $500 \mathrm{mg} / \mathrm{L}$ of dissolved solids is undesirable for drinking and many industrial uses. See also freshwater. 
self-supplied water use Water withdrawn from a groundwater or surface-water source by a user rather than being obtained from a public supply.

\section{Standard Industrial Classification (SIC)}

codes Four-digit codes established by the Office of Management and Budget, published in 1987, and used in the classification of establishments by type of activity in which they are engaged.

\section{$\mathbf{T}$}

thermoelectric-power water use Water used in the process of generating electricity with steam-driven turbine generators. Term used in water-use circulars before 2000 to describe the combined public-supply deliveries to thermoelectric powerplants and self-supplied thermoelectric-power water withdrawals. For 2000 and 2005, thermoelectric-power water use refers only to self-supplied thermoelectric-power withdrawals. See also cooling system, cooling-system type, public-supply water use, and self-supplied water use.

transpiration The process in which water is absorbed by plants, usually from the roots and evaporated into the atmosphere from the plant surface. Transpiration occurs in all types of plants including trees, crops, grass (lawns, golf courses), landscaping plants, and nursery plants. See also evaporation and evapotranspiration.

\section{U}

uncertainty Used qualitatively to describe potential errors and biases associated with measurements, calculations, and estimates.

\section{V}

W

wastewater returns Water returned to the hydrologic system by wastewater-treatment facilities. See also return flow. water use (1) In a restrictive sense, the term refers to water that is withdrawn for a specific purpose, such as for public supply, domestic use, irrigation, thermoelectric-power cooling, or industrial processing. In water-use circulars before 2000, water use for the domestic commercial, industrial, and thermoelectric-power categories included both self-supplied withdrawals and deliveries from public supply. (2) More broadly, water use pertains to the interaction of humans with and influence on the hydrologic cycle, and includes elements such as water withdrawal, delivery, consumptive use, wastewater release, reclaimed wastewater, return flow, and instream use. See also offstream use, instream use, and water-use category.

water-use category The type of specific use (facility or consumer) for which water is withdrawn. For the USGS National Water Use Inventory Program, estimation of the quantities of certain elements of use is considered mandatory. For the 2005 compilation for counties and watersheds designated by 8 -digit hydrologic (cataloging) unit code, these categories are public supply, self-supplied domestic, thermoelectric power, industrial, mining, irrigation, aquaculture, livestock, and reclaimed wastewater. Commercial use was not a mandatory category in 2005; however, selected estimates withdrawals and other elements of commercial use are available and are presented in this report.

withdrawal Removal of water from either a surface-water or groundwater source. See also offstream use and self-supplied water use.

\section{$\mathbf{X}$}

$\mathbf{Y}$ 


\section{Appendix 1. Estimates of Withdrawals and Other Elements of Water Use by 8-Digit Hydrologic (Cataloging) Unit Codes (HUC) in the Great Lakes Basin, 2005. A, Data Dictionary. B, Estimates by State. C, Estimates by Watershed (8-digit HUC).}

\section{Appendix 1A: Data Dictionary}

The following listings describe the columns of water-use estimates for hydrologic (cataloging) units (HUC, 8 digit) in the Great Lakes Basin contained in the spreadsheet data files included as appendixes $1 B$ and $1 C$. The first line of the spreadsheet file contains "Column Tags," which match those presented below. The descriptions for the column tags are presented under "Data Description" in the listing.
All data are expressed in million gallons per day $(\mathrm{Mgal} / \mathrm{d})$, except area, which are in square miles $\left(\mathrm{mi}^{2}\right)$ and percent; population values, which are in thousands; per capita values, which are in gallons per day (gal/d); power-generated values, which are in gigawatt-hours (GWh); acres irrigated, which are in thousands; and intensity of withdrawal values, which are in million gallons per day per square mile (Mgal/d/ $\mathrm{mi}^{2}$ ) and $\mathrm{gal} / \mathrm{d}$.

Column and data descriptors for Appendix 1B: Estimates by State

\begin{tabular}{|c|c|}
\hline Column tag & Data description \\
\hline YEARH & Year of data \\
\hline STATE & State postal abbreviation \\
\hline HUC8Code & HUC code ( 8 digit) \\
\hline HUC8Name & HUC name ( 8 digit) \\
\hline AREA & Area of HUC ( 8 digit) in the state, in $\mathrm{mi}^{2}$ \\
\hline AREA \% & Area of HUC ( 8 digit) in the state relative to total area of $\mathrm{HUC}$, in percent \\
\hline TP-TotalPop & Total population of HUC ( 8 digit), in thousands \\
\hline PS-TOPop & Public supply, total population served, in thousands \\
\hline PS-WGWFr & Public supply, groundwater withdrawals, fresh, in Mgal/d \\
\hline PS-WSWFr & Public supply, surface-water withdrawals, fresh, in Mgal/d \\
\hline PS-PrCap & Public supply, per capita use (withdrawal), in gal/d \\
\hline DO-SSPop & Domestic, self-supplied population, in thousands \\
\hline DO-WGWFr & Domestic, groundwater self-supplied withdrawals, fresh, in Mgal/d \\
\hline DO-WSWFr & Domestic, surface-water self-supplied withdrawals, fresh, in Mgal/d \\
\hline DO-SSPCp & Domestic, per capita use (withdrawal), self-supplied, in gal/d \\
\hline DO-PSDel & Domestic, deliveries from public supplies, in Mgal/d \\
\hline PT-WGWFr & Thermoelectric power, groundwater withdrawals, fresh, in Mgal/d \\
\hline PT-WSWFr & Thermoelectric power, surface-water withdrawals, fresh, in Mgal/d \\
\hline PT-Power & Power generation, in GWh \\
\hline PO-WGWFr & Thermoelectric power once-through, groundwater withdrawals, fresh, in Mgal/d \\
\hline PO-WSWFr & Thermoelectric power once-through, surface-water withdrawals, fresh, in Mgal/d \\
\hline
\end{tabular}


Column and data descriptors for Appendix 1B: Estimates by State

\begin{tabular}{|c|c|}
\hline Column tag & Data description \\
\hline PO-Power & Power generation once-through, in GWh \\
\hline PC-WGWFr & Thermoelectric power closed-loop, groundwater withdrawals, fresh, in Mgal/d \\
\hline PC-WSWFr & Thermoelectric power closed-loop, surface-water withdrawals, fresh, in Mgal/d \\
\hline PC-Power & Power generation closed-loop, in GWh \\
\hline IN-WGWFr & Industrial, groundwater self-supplied withdrawals, fresh, in Mgal/d \\
\hline IN-WSWFr & Industrial, surface-water self-supplied withdrawals, fresh, in Mgal/d \\
\hline IN-RecWW & Industrial use, reclaimed wastewater, in Mgal/d \\
\hline MI-GWFr & Mining, groundwater withdrawals, fresh, in Mgal/d \\
\hline MI-GWSa & Mining, groundwater withdrawals, saline, in Mgal/d \\
\hline MI-SWFr & Mining, surface-water withdrawals, fresh, in Mgal/d \\
\hline MI-SWSa & Mining, surface-water withdrawals, saline, in Mgal/d \\
\hline IG-WGWFr & Irrigation, golf course, groundwater withdrawals, fresh, in Mgal/d \\
\hline IG-WSWFr & Irrigation, golf course, surface-water withdrawals, fresh, in Mgal/d \\
\hline IT-WGWFr & Irrigation, all, groundwater withdrawals, fresh, in $\mathrm{Mgal} / \mathrm{d}$ \\
\hline IT-WSWFr & Irrigation, all, surface-water withdrawals, fresh, in Mgal/d \\
\hline IT-IrSpr & Irrigation, all, acres irrigated, sprinkler, in thousands \\
\hline IT-IRMic & Irrigation, all, acres irrigated, microirrigation, in thousands \\
\hline IT-IrSur & Irrigation, all, acres irrigated, surface, in thousands \\
\hline IT-RecWW & Irrigation use, reclaimed wastewater, in $\mathrm{Mgal} / \mathrm{d}$ \\
\hline LA-WGWFr & Aquaculture, groundwater withdrawals, fresh, in Mgal/d \\
\hline LA-WSWFr & Aquaculture, surface-water withdrawals, fresh, in Mgal/d \\
\hline LS-WGWFr & Livestock, groundwater withdrawals, fresh, in Mgal/d \\
\hline LS-WSWFr & Livestock, surface-water withdrawals, fresh, in $\mathrm{Mgal} / \mathrm{d}$ \\
\hline CO-WGWFr & Commercial, groundwater withdrawals, fresh, in Mgal/d \\
\hline CO-WSWFr & Commercial, surface-water withdrawals, fresh, in $\mathrm{Mgal} / \mathrm{d}$ \\
\hline
\end{tabular}


Column and data descriptors for Appendix 1C: Estimates by Watershed (8-digit HUC)

\begin{tabular}{|c|c|}
\hline Column tag & Data description \\
\hline HUC8Code & HUC code (8 digit) \\
\hline HUC8Name & HUC name ( 8 digit) \\
\hline AREA & Area of HUC ( 8 digit) in the state, in $\mathrm{mi}^{2}$ \\
\hline INTEN-A & Intensity of water withdrawals, as a function of land area, in $\mathrm{Mgal} / \mathrm{d} / \mathrm{mi}^{2}$ \\
\hline INTEN-PC & Intensity of water withdrawals, as a function of per capita use, in gal/d \\
\hline TP-TotalPop & Total population of HUC ( 8 digit), in thousands \\
\hline PS-Wtotal & Public supply, total withdrawals, in Mgal/d \\
\hline PS-WGWFr & Public supply, groundwater withdrawals, fresh, in Mgal/d \\
\hline PS-WSWFr & Public supply, surface-water withdrawals, fresh, in Mgal/d \\
\hline DO-SSPop & Domestic, self-supplied population, in thousands \\
\hline DO-Wtotal & Domestic, total self-supplied withdrawals, in Mgal/d \\
\hline DO-WGWFr & Domestic, groundwater self-supplied withdrawals, fresh, in Mgal/d \\
\hline DO-WSWFr & Domestic, surface-water self-supplied withdrawals, fresh, in Mgal/d \\
\hline DO-PSDel & Domestic, deliveries from public supplies, in Mgal/d \\
\hline PT-Wtotal & Thermoelectric power, total withdrawals, in Mgal/d \\
\hline PT-WGWFr & Thermoelectric power, groundwater withdrawals, fresh, in Mgal/d \\
\hline PT-WSWFr & Thermoelectric power, surface-water withdrawals, fresh, in Mgal/d \\
\hline IN-Wtotal & Industrial, total withdrawals, in Mgal/d \\
\hline IN-WGWFr & Industrial, groundwater self-supplied withdrawals, fresh, in Mgal/d \\
\hline IN-WSWFr & Industrial, surface-water self-supplied withdrawals, fresh, in Mgal/d \\
\hline MI-Wtotal & Mining, total withdrawals, in Mgal/d \\
\hline MI-WGWto & Mining, groundwater withdrawals, total (fresh and saline), in Mgal/d \\
\hline MI-WSW to & Mining, surface-water withdrawals, total (fresh and saline), in Mgal/d \\
\hline IT-Wtotal & Irrigation, all, total withdrawals, in Mgal/d \\
\hline IT-WGWFr & Irrigation, all, groundwater withdrawals, fresh, in Mgal/d \\
\hline IT-WSWFr & Irrigation, all, surface-water withdrawals, fresh, in Mgal/d \\
\hline LA-Wtotal & Aquaculture, total withdrawals, in Mgal/d \\
\hline LA-WGWFr & Aquaculture, groundwater withdrawals, fresh, in Mgal/d \\
\hline LA-WSWFr & Aquaculture, surface-water withdrawals, fresh, in Mgal/d \\
\hline LS-Wtotal & Livestock, total withdrawals, in Mgal/d \\
\hline LS-WGWFr & Livestock, groundwater withdrawals, fresh, in Mgal/d \\
\hline LS-WSWFr & Livestock, surface-water withdrawals, fresh, in Mgal/d \\
\hline
\end{tabular}


Appendix 1B. Estimates of Withdrawals and Other Elements of Water Use by State.

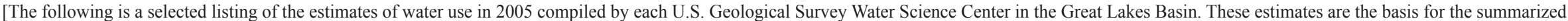
findings presented elsewhere in this report. The compiled values from selected New York watersheds (8-digit HUCs) are preliminary; these values are identified by bold typeface. A complete listing of estimates, including final, approved values from New York HUCs, is available for download from the U.S. Geological Survey National Water-Use Information Web site (http://water.usgs.gov/watuse). Approximate areas

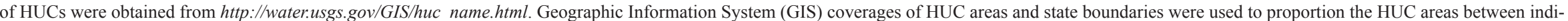
vidual Great Lakes States. Column tags are defined in appendix 1A. Data Dictionary; NA, not applicable; NR, not reported; NULL, value unknown, not reported]

\begin{tabular}{|c|c|c|c|c|c|c|c|c|c|c|c|c|c|c|c|c|c|c|c|c|c|c|c|}
\hline STATE & HUC8Code & HUC8Name & AREA & AREA $\%$ & $\begin{array}{l}\text { TP-Total- } \\
\text { Pop }\end{array}$ & $\begin{array}{l}\text { PS- } \\
\text { TOPop }\end{array}$ & $\begin{array}{c}\text { PS- } \\
\text { WGWFr }\end{array}$ & $\begin{array}{c}\text { PS- } \\
\text { WSWFr }\end{array}$ & $\begin{array}{l}\text { PS- } \\
\text { PrCap }\end{array}$ & $\begin{array}{l}\text { DO- } \\
\text { SSPop }\end{array}$ & $\begin{array}{c}\text { DO- } \\
\text { WGWFr }\end{array}$ & $\begin{array}{c}\text { DO- } \\
\text { WSWFr }\end{array}$ & $\begin{array}{l}\text { DO- } \\
\text { SSPCp }\end{array}$ & $\begin{array}{l}\text { DO- } \\
\text { PSDel }\end{array}$ & $\begin{array}{c}\text { PT- } \\
\text { WGWFr }\end{array}$ & $\begin{array}{c}\text { PT- } \\
\text { WSWFr }\end{array}$ & $\begin{array}{l}\text { PT- } \\
\text { Power }\end{array}$ & $\begin{array}{c}\text { PO- } \\
\text { WGWFr }\end{array}$ & $\begin{array}{l}\text { P0- } \\
\text { WSWFr }\end{array}$ & $\begin{array}{l}\text { PO- } \\
\text { Power }\end{array}$ & $\begin{array}{l}\text { PC- } \\
\text { WGWFr }\end{array}$ & $\begin{array}{c}\text { PC- } \\
\text { WSWFr }\end{array}$ & $\begin{array}{l}\text { PC- } \\
\text { Power }\end{array}$ \\
\hline IL & 04040001 & $\begin{array}{l}\text { Little Calumet- } \\
\text { Galien }\end{array}$ & 28 & 4 & 40.196 & 40.20 & 0.00 & 0.00 & 0 & 0.00 & 0.00 & 0.00 & 0 & 3.62 & 0.00 & 0.00 & 0.00 & 0.00 & 0.00 & 0.00 & 0.00 & 0.00 & 0.00 \\
\hline IL & 04040002 & Pike-Root & 62 & 16 & 624.009 & 623.17 & 0.01 & 0.00 & 0 & 0.84 & 0.08 & 0.00 & 96 & 56.09 & 0.00 & 0.00 & 0.00 & 0.00 & 0.00 & 0.00 & 0.00 & 0.00 & 0.00 \\
\hline IL & 04060200 & Lake Michigan & 1,560 & 7 & 3.295 & 3.30 & 0.00 & $1,023.70$ & NA & 0.00 & 0.00 & 0.00 & 0 & 0.30 & 0.00 & 758.32 & $4,560.50$ & 0.00 & 758.32 & $4,560.50$ & 0.00 & 0.00 & 0.00 \\
\hline IN & 04040001 & $\begin{array}{l}\text { Little Calumet- } \\
\text { Galien }\end{array}$ & 521 & 74 & 445.745 & 391.23 & 1.00 & 0.00 & 3 & 54.52 & 4.14 & 0.00 & 76 & 29.73 & 0.00 & 0.00 & 0.00 & 0.00 & 0.00 & 0.00 & 0.00 & 0.00 & 0.00 \\
\hline IN & 04050001 & St. Joseph & 1,682 & 36 & 541.578 & 307.94 & 48.51 & 0.00 & 158 & 233.64 & 17.76 & 0.00 & 76 & 23.40 & 0.00 & 0.00 & 0.00 & 0.00 & 0.00 & 0.00 & 0.00 & 0.00 & 0.00 \\
\hline IN & 04100003 & St. Joseph & 591 & 56 & 137.059 & 82.12 & 8.15 & 33.27 & 504 & 54.94 & 4.17 & 0.00 & 76 & 6.24 & 0.27 & 0.00 & 0.00 & 0.00 & 0.00 & 0.00 & 0.27 & 0.00 & 0.00 \\
\hline IN & 04100004 & St. Marys & 384 & 47 & 159.889 & 148.85 & 2.97 & 0.00 & 20 & 11.04 & 0.84 & 0.00 & 76 & 11.31 & 0.00 & 0.00 & 0.00 & 0.00 & 0.00 & 0.00 & 0.00 & 0.00 & 0.00 \\
\hline IN & 04100005 & Upper Maumee & 201 & 52 & 82.686 & 71.50 & 0.00 & 0.00 & 0 & 11.19 & 0.85 & 0.00 & 76 & 5.43 & 0.00 & 0.00 & 0.00 & 0.00 & 0.00 & 0.00 & 0.00 & 0.00 & 0.00 \\
\hline IN & 04100007 & Auglaize & 104 & 6 & 2.837 & 1.04 & 0.11 & 0.00 & 106 & 1.80 & 0.14 & 0.00 & 78 & 0.08 & 0.00 & 0.00 & 0.00 & 0.00 & 0.00 & 0.00 & 0.00 & 0.00 & 0.00 \\
\hline IN & 04060200 & Lake Michigan & 231 & 1 & 0.000 & 0.00 & 0.00 & 76.81 & 0 & 0.00 & 0.00 & 0.00 & 0 & 0.00 & 0.00 & 727.86 & $7,974.68$ & 0.00 & 721.87 & $5,429.00$ & 0.00 & 5.99 & $2,545.68$ \\
\hline MI & 04010302 & Bad-Montreal & 106 & 8 & 3 & 8.90 & 0.96 & 0.00 & 108 & 0.03 & 0.00 & 0.00 & 0 & 0.53 & 0.00 & 0.00 & 0.00 & 0.00 & 0.00 & 0.00 & 0.00 & 0.00 & 0.00 \\
\hline MI & 04020101 & $\begin{array}{l}\text { Black- } \\
\quad \text { Presque Isle }\end{array}$ & 959 & 93 & 9 & 7.20 & 0.69 & 0.00 & 96 & 0.04 & 0.00 & 0.00 & 0 & 0.50 & 0.00 & 0.00 & 0.00 & 0.00 & 0.00 & 0.00 & 0.00 & 0.00 & 0.00 \\
\hline MI & 04020102 & Ontonagon & 1,349 & 97 & 5.910 & 3.77 & 0.14 & 0.00 & 127 & 2.14 & 0.19 & 0.00 & 89 & 0.19 & 0.00 & 0.00 & 0.00 & 0.00 & 0.00 & 0.00 & 0.00 & 0.00 & 0.00 \\
\hline MI & 04020103 & $\begin{array}{l}\text { Keweenaw } \\
\text { Peninsula }\end{array}$ & 1,130 & 100 & 38.237 & 29.32 & 3.53 & 0.00 & 121 & 8.92 & 0.77 & 0.00 & 86 & 2.19 & 0.00 & 0.00 & 0.00 & 0.00 & 0.00 & 0.00 & 0.00 & 0.00 & 0.00 \\
\hline MI & 04020104 & Sturgeon & 710 & 100 & 2.602 & 0.04 & 0.00 & 0.00 & 0 & 2.56 & 0.22 & 0.00 & 86 & 0.00 & 0.00 & 0.00 & 0.00 & 0.00 & 0.00 & 0.00 & 0.00 & 0.00 & 0.00 \\
\hline MI & 04020105 & Dead-Kelsey & 946 & 100 & 47.498 & 45.00 & 1.42 & 0.00 & 117 & 2.49 & 0.22 & 0.00 & 88 & 3.13 & 0.00 & 0.00 & $3,760.48$ & 0.00 & 270.13 & $3,760.48$ & 0.00 & 0.00 & 0.00 \\
\hline MI & 04020201 & Betsy-Chocolay & 1,180 & 100 & 19.706 & 4.50 & 0.56 & 0.00 & 124 & 15.21 & 1.31 & 0.00 & 86 & 0.40 & 0.00 & 0.00 & 0.00 & 0.00 & 0.00 & 0.00 & 0.00 & 0.00 & 0.00 \\
\hline MI & 04020202 & Tahquamenon & 832 & 100 & 5.775 & 3.15 & 0.55 & 0.00 & 175 & 2.63 & 0.23 & 0.00 & 88 & 0.23 & 0.00 & 0.00 & 0.00 & 0.00 & 0.00 & 0.00 & 0.00 & 0.00 & 0.00 \\
\hline MI & 04020203 & Waiska & 324 & 100 & 8.194 & 0.72 & 0.05 & 0.00 & 69 & 7.47 & 0.64 & 0.00 & 86 & 0.04 & 0.00 & 0.00 & 0.00 & 0.00 & 0.00 & 0.00 & 0.00 & 0.00 & 0.00 \\
\hline MI & 04030106 & Brule & 872 & 82 & 13.405 & 12.25 & 2.03 & 0.00 & 166 & 1.16 & 0.10 & 0.00 & 86 & 0.88 & 0.00 & 0.00 & 0.00 & 0.00 & 0.00 & 0.00 & 0.00 & 0.00 & 0.00 \\
\hline MI & 04030107 & Michigamme & 734 & 100 & 2.189 & 0.70 & 0.15 & 0.00 & 214 & 1.49 & 0.13 & 0.00 & 87 & 0.10 & 0.00 & 0.00 & 0.00 & 0.00 & 0.00 & 0.00 & 0.00 & 0.00 & 0.00 \\
\hline MI & 04030108 & Menominee & 987 & 43 & 39.376 & 21.38 & 3.00 & 0.00 & 140 & 18.00 & 1.55 & 0.00 & 86 & 1.91 & 0.00 & 0.00 & 0.00 & 0.00 & 0.00 & 0.00 & 0.00 & 0.00 & 0.00 \\
\hline MI & 04030109 & Cedar-Ford & 1,010 & 100 & 19.069 & 10.30 & 0.06 & 0.00 & 127 & 8.77 & 0.76 & 0.00 & 87 & 0.57 & 0.00 & 0.00 & 0.00 & 0.00 & 0.00 & 0.00 & 0.00 & 0.00 & 0.00 \\
\hline MI & 04030110 & Escanaba & 935 & 100 & 19.058 & 5.83 & 0.91 & 0.00 & 156 & 13.22 & 1.14 & 0.00 & 86 & 0.53 & 0.00 & 0.00 & 0.00 & 0.00 & 0.00 & 0.00 & 0.00 & 0.00 & 0.00 \\
\hline MI & 04030111 & $\begin{array}{l}\text { Tacoosh- } \\
\text { Whitefish }\end{array}$ & 656 & 100 & 23.849 & 18.98 & 0.12 & 0.00 & 142 & 4.86 & 0.42 & 0.00 & 86 & 1.21 & 0.00 & 0.00 & 159.89 & 0.00 & 21.96 & 159.89 & 0.00 & 0.00 & 0.00 \\
\hline MI & 04030112 & $\begin{array}{l}\text { Fishdam- } \\
\text { Sturgeon }\end{array}$ & 556 & 100 & 1.752 & 0.27 & 0.03 & 0.00 & 111 & 1.48 & 0.13 & 0.00 & 88 & 0.03 & 0.00 & 0.00 & 0.00 & 0.00 & 0.00 & 0.00 & 0.00 & 0.00 & 0.00 \\
\hline
\end{tabular}


Appendix 1B. Estimates of Withdrawals and Other Elements of Water Use by State.-Continued

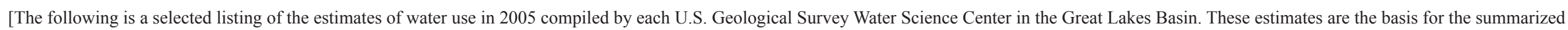

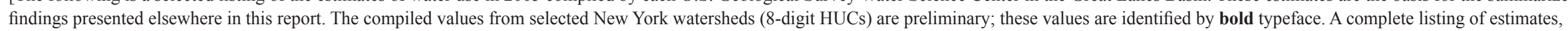

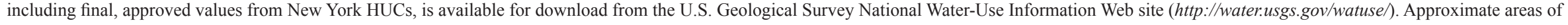

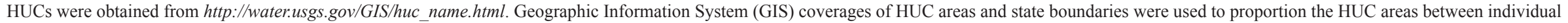
Great Lakes States. Column tags are defined in appendix 1A. Data Dictionary; NA, not applicable; NR, not reported; NULL, value unknown, not reported]

\begin{tabular}{|c|c|c|c|c|c|c|c|c|c|c|c|c|c|c|c|c|c|c|c|c|c|c|c|}
\hline STATE & HUC8Code & HUC8Name & $\begin{array}{c}\text { IN- } \\
\text { WGWFr }\end{array}$ & $\begin{array}{c}\text { IN- } \\
\text { WSWFr }\end{array}$ & $\begin{array}{c}\text { IN- } \\
\text { RecWW }\end{array}$ & $\begin{array}{c}\text { MI- } \\
\text { WGWFr }\end{array}$ & $\begin{array}{c}\text { MI- } \\
\text { WGWSa }\end{array}$ & $\begin{array}{c}\text { MI- } \\
\text { WSWFr }\end{array}$ & $\begin{array}{c}\text { MI- } \\
\text { WSWSa }\end{array}$ & $\begin{array}{c}\text { IG- } \\
\text { WGWFr }\end{array}$ & $\begin{array}{c}\text { IG- } \\
\text { WSWFr }\end{array}$ & $\begin{array}{c}\text { IT- } \\
\text { WGWFr }\end{array}$ & $\begin{array}{c}\text { IT- } \\
\text { WSWFr }\end{array}$ & $\begin{array}{l}\text { IT- } \\
\text { IrSpr }\end{array}$ & $\begin{array}{l}\text { IT- } \\
\text { IrMic }\end{array}$ & $\begin{array}{l}\text { IT- } \\
\text { IrSur }\end{array}$ & $\begin{array}{c}\text { IT- } \\
\text { RecWW }\end{array}$ & $\begin{array}{l}\text { LA- } \\
\text { WGWFr }\end{array}$ & $\begin{array}{c}\text { LA- } \\
\text { WSWFr }\end{array}$ & $\begin{array}{c}\text { LS- } \\
\text { WGWFr }\end{array}$ & $\begin{array}{c}\text { LS- } \\
\text { WSWFr }\end{array}$ & $\begin{array}{c}\text { CO- } \\
\text { WGWFr }\end{array}$ & $\begin{array}{c}\text { Co- } \\
\text { WSWFr }\end{array}$ \\
\hline IL & 04040001 & $\begin{array}{l}\text { Little Calumet- } \\
\quad \text { Galien }\end{array}$ & 0.00 & 7.27 & 0.00 & 0.00 & 0.00 & 0.00 & 0.00 & 0.00 & 0.25 & 0.00 & 0.25 & 0.09 & 0.00 & 0.00 & 0.00 & 0.00 & 0.00 & 0.00 & 0.00 & 0.00 & 0.00 \\
\hline IL & 04040002 & Pike-Root & 0.00 & 0.00 & 0.00 & 0.00 & 0.00 & 0.00 & 0.00 & 0.44 & 0.02 & 0.44 & 0.02 & 0.24 & 0.00 & 0.00 & 0.00 & 0.00 & 0.00 & 0.00 & 0.00 & 0.00 & 0.00 \\
\hline $\mathrm{IL}$ & 04060200 & Lake Michigan & 0.00 & 11.25 & 0.00 & 0.00 & 0.00 & 0.00 & 0.00 & 0.00 & 0.00 & 0.00 & 0.00 & 0.00 & 0.00 & 0.00 & 0.00 & 0.00 & 0.00 & 0.00 & 0.00 & 0.00 & 0.02 \\
\hline IN & 04040001 & $\begin{array}{l}\text { Little Calumet- } \\
\text { Galien }\end{array}$ & 1.95 & 301.16 & 0.00 & 0.00 & 0.00 & 0.00 & 0.00 & NR & NR & 0.24 & 0.09 & 2.05 & 0.00 & 0.00 & 0.00 & 0.00 & 0.00 & 0.09 & 0.10 & 0.79 & 0.66 \\
\hline IN & 04050001 & St. Joseph & 4.22 & 1.71 & 0.00 & 0.37 & 0.00 & 2.51 & 0.00 & NR & NR & 26.48 & 5.09 & 68.53 & 0.00 & 0.00 & 0.00 & 0.00 & 0.00 & 2.36 & 1.56 & 11.46 & 15.67 \\
\hline IN & 04100003 & St. Joseph & 3.86 & 0.28 & 0.00 & 0.00 & 0.00 & 0.43 & 0.00 & NR & NR & 0.14 & 0.03 & 1.28 & 0.00 & 0.00 & 0.00 & 0.00 & 0.00 & 0.31 & 0.26 & 0.60 & 0.32 \\
\hline IN & 04100004 & St. Marys & 0.10 & 1.44 & 0.00 & 0.00 & 0.00 & 0.38 & 0.00 & NR & NR & 0.00 & 0.00 & 0.66 & 0.00 & 0.00 & 0.00 & 0.00 & 0.00 & 0.65 & 0.19 & 0.49 & 0.00 \\
\hline IN & 04100005 & Upper Maumee & 0.63 & 1.16 & 0.00 & 0.00 & 0.00 & 0.73 & 0.00 & NR & NR & 0.02 & 0.02 & 0.29 & 0.00 & 0.00 & 0.00 & 0.00 & 0.00 & 0.09 & 0.08 & 0.14 & 0.06 \\
\hline IN & 04100007 & Auglaize & 0.00 & 0.00 & 0.00 & 0.00 & 0.00 & 0.00 & 0.00 & NR & NR & 0.00 & 0.00 & 0.00 & 0.00 & 0.00 & 0.00 & 0.00 & 0.00 & 0.07 & 0.04 & 0.01 & 0.00 \\
\hline IN & 04060200 & Lake Michigan & 0.32 & $1,307.76$ & 0.00 & 0.00 & 0.00 & 0.00 & 0.00 & NR & NR & 0.00 & 0.00 & 0.00 & 0.00 & 0.00 & 0.00 & 0.00 & 0.00 & 0.00 & 0.00 & 0.09 & 0.03 \\
\hline MI & 04010302 & Bad-Montreal & 0.08 & 0.00 & NULL & 0.00 & 0.00 & 0.00 & 0.00 & 0.00 & 0.00 & 0.00 & 0.00 & 0.00 & 0.00 & 0.00 & NULL & 0.00 & 0.83 & 0.00 & 0.00 & NR & NR \\
\hline MI & 04020101 & $\begin{array}{l}\text { Black- } \\
\text { Presque Isle }\end{array}$ & 0.00 & 0.00 & NULL & 0.01 & 0.00 & 0.03 & 0.00 & 0.00 & 0.00 & 0.00 & 0.00 & 0.00 & 0.00 & 0.00 & NULL & 0.00 & 4.68 & 0.01 & 0.00 & NR & NR \\
\hline MI & 04020102 & Ontonagon & 0.00 & 0.00 & NULL & 0.01 & 0.00 & 0.05 & 0.00 & 0.00 & 0.00 & 0.00 & 0.00 & 0.00 & 0.00 & 0.00 & NULL & 0.00 & 3.52 & 0.03 & 0.00 & NR & NR \\
\hline MI & 04020103 & $\begin{array}{l}\text { Keweenaw } \\
\text { Peninsula }\end{array}$ & 0.00 & 0.00 & NULL & 0.00 & 0.00 & 0.06 & 0.00 & 0.01 & 0.02 & 0.01 & 0.02 & 0.10 & 0.00 & 0.00 & NULL & 0.00 & 0.00 & 0.02 & 0.00 & NR & NR \\
\hline MI & 04020104 & Sturgeon & 0.00 & 0.00 & NULL & 0.00 & 0.00 & 0.05 & 0.00 & 0.00 & 0.00 & 0.00 & 0.00 & 0.00 & 0.00 & 0.00 & NULL & 0.00 & 0.00 & 0.02 & 0.00 & NR & NR \\
\hline MI & 04020105 & Dead-Kelsey & 0.00 & 0.00 & NULL & 2.71 & 0.00 & 10.88 & 0.00 & 0.05 & 0.05 & 0.05 & 0.05 & 0.13 & 0.00 & 0.00 & NULL & 0.00 & 0.00 & 0.02 & 0.00 & NR & NR \\
\hline MI & 04020201 & Betsy-Chocolay & 0.35 & 0.00 & NULL & 0.84 & 0.00 & 3.42 & 0.00 & 0.00 & 0.00 & 0.01 & 0.01 & 0.00 & 0.00 & 0.00 & NULL & 0.14 & 0.05 & 0.03 & 0.00 & NR & NR \\
\hline MI & 04020202 & Tahquamenon & 0.04 & 0.00 & NULL & 0.01 & 0.00 & 0.22 & 0.00 & 0.00 & 0.06 & 0.01 & 0.07 & 0.13 & 0.00 & 0.00 & NULL & 0.35 & 0.12 & 0.02 & 0.00 & NR & NR \\
\hline MI & 04020203 & Waiska & 0.00 & 0.00 & NULL & 0.01 & 0.00 & 0.19 & 0.00 & 0.00 & 0.05 & 0.00 & 0.05 & 0.04 & 0.00 & 0.00 & NULL & 0.39 & 0.14 & 0.02 & 0.00 & NR & NR \\
\hline MI & 04030106 & Brule & 0.00 & 0.00 & NULL & 0.03 & 0.00 & 0.11 & 0.00 & 0.03 & 0.00 & 0.03 & 0.00 & 0.11 & 0.00 & 0.00 & NULL & 0.00 & 0.08 & 0.01 & 0.00 & NR & NR \\
\hline MI & 04030107 & Michigamme & 0.00 & 0.00 & NULL & 1.14 & 0.00 & 4.59 & 0.00 & 0.00 & 0.00 & 0.10 & 0.52 & 0.73 & 0.02 & 0.02 & NULL & 0.00 & 0.00 & 0.01 & 0.00 & NR & NR \\
\hline MI & 04030108 & Menominee & 0.43 & 21.76 & NULL & 0.01 & 0.00 & 0.13 & 0.00 & 0.06 & 0.11 & 0.12 & 0.23 & 0.15 & 0.00 & 0.00 & NULL & 0.00 & 0.00 & 0.17 & 0.02 & NR & NR \\
\hline MI & 04030109 & Cedar-Ford & 0.03 & 0.00 & NULL & 0.31 & 0.00 & 1.35 & 0.00 & 0.01 & 0.00 & 0.02 & 0.02 & 0.04 & 0.00 & 0.00 & NULL & 0.00 & 0.00 & 0.19 & 0.02 & NR & NR \\
\hline MI & 04030110 & Escanaba & 0.16 & 18.92 & NULL & 3.70 & 0.00 & 14.86 & 0.00 & 0.00 & 0.19 & 0.09 & 0.47 & 0.55 & 0.01 & 0.01 & NULL & 0.00 & 0.00 & 0.03 & 0.00 & NR & NR \\
\hline MI & 04030111 & $\begin{array}{l}\text { Tacoosh- } \\
\text { Whitefish }\end{array}$ & 0.11 & 0.40 & NULL & 0.39 & 0.00 & 1.61 & 0.00 & 0.04 & 0.06 & 0.04 & 0.06 & 0.21 & 0.00 & 0.00 & NULL & 0.00 & 0.00 & 0.04 & 0.01 & NR & NR \\
\hline MI & 04030112 & $\begin{array}{l}\text { Fishdam- } \\
\text { Sturgeon }\end{array}$ & 0.00 & 0.00 & NULL & 0.00 & 0.01 & 0.14 & 0.00 & 0.02 & 0.00 & 0.02 & 0.00 & 0.02 & 0.00 & 0.00 & NULL & 0.00 & 0.00 & 0.03 & 0.01 & NR & NR \\
\hline
\end{tabular}




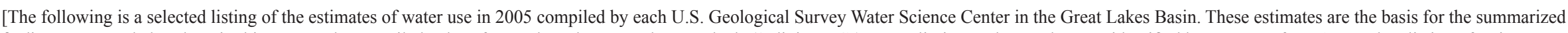
findings presented elsewhere in this report. The compiled values from selected New York watersheds (8-digit HUCs) are preliminary; these values are identified by bold typeface. A complete listing of estimates, including final, approved values from New York HUCs, is available for download from the U.S. Geological Survey National Water-Use Information Web site (http://water.usgs.gov/watuse). Approximate areas

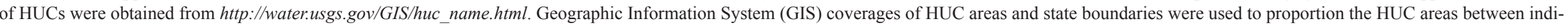
vidual Great Lakes States. Column tags are defined in appendix 1A. Data Dictionary; NA, not applicable; NR, not reported; NULL, value unknown, not reported]

\begin{tabular}{|c|c|c|c|c|c|c|c|c|c|c|c|c|c|c|c|c|c|c|c|c|c|c|c|}
\hline STATE & HUC8Code & HUC8Name & REA & AREA\% $\%$ & $\begin{array}{l}\text { TP-Total- } \\
\text { Pop }\end{array}$ & $\begin{array}{l}\text { PS- } \\
\text { TOPop }\end{array}$ & $\begin{array}{c}\text { PS- } \\
\text { WGWFr }\end{array}$ & $\begin{array}{c}\text { PS- } \\
\text { WSWFr }\end{array}$ & $\begin{array}{l}\text { PS- } \\
\text { PrCap }\end{array}$ & $\begin{array}{l}\text { DO- } \\
\text { SSPop }\end{array}$ & $\begin{array}{c}\text { DO- } \\
\text { WGWFr }\end{array}$ & $\begin{array}{c}\text { DO- } \\
\text { WSWFr }\end{array}$ & $\begin{array}{l}\text { DO- } \\
\text { SSPCp }\end{array}$ & $\begin{array}{l}\text { DO- } \\
\text { PSDel }\end{array}$ & $\begin{array}{c}\text { PT- } \\
\text { WGWFr }\end{array}$ & $\begin{array}{c}\text { PT- } \\
\text { WSWFr }\end{array}$ & $\begin{array}{l}\text { PT- } \\
\text { Power }\end{array}$ & $\begin{array}{c}\text { PO- } \\
\text { WGWFr }\end{array}$ & $\begin{array}{c}\text { Po- } \\
\text { WSWFr }\end{array}$ & $\begin{array}{l}\text { P0- } \\
\text { Power }\end{array}$ & $\begin{array}{c}\text { PC- } \\
\text { WGWFr }\end{array}$ & $\begin{array}{c}\text { PC- } \\
\text { WSWFr }\end{array}$ & $\begin{array}{l}\text { PC- } \\
\text { Power }\end{array}$ \\
\hline MI & 04040001 & $\begin{array}{l}\text { Little Calumet- } \\
\text { Galien }\end{array}$ & 57 & 22 & 25.856 & 13.64 & 18 & 0.00 & 260 & 12.22 & 1.05 & 0.00 & 86 & 1.05 & 0.00 & 0.00 & $18,057.27$ & 0.00 & $2,290.65$ & $18,057.27$ & 0.00 & 0.00 & 0.00 \\
\hline MI & 04050001 & St. Joseph & 2,988 & 64 & 403.193 & 254.95 & 25.31 & 0.00 & 132 & 148.25 & 12.79 & 0.00 & 86 & 17.36 & 1.26 & 0.05 & 425.70 & 1.26 & 0.05 & 425.70 & 0.00 & 0.00 & 0.00 \\
\hline MI & 04050002 & Black-Macatawa & 600 & 100 & 170.797 & 90.49 & 0.68 & 0.00 & 580 & 80.31 & 6.93 & 0.00 & 86 & 6.61 & 0.82 & 0.00 & $16,315.34$ & 0.82 & 854.98 & $16,315.34$ & 0.00 & 0.00 & 0.00 \\
\hline MI & 04050003 & Kalamazoo & 2,030 & 100 & 492.608 & 266.44 & 39.50 & 0.00 & 148 & 226.17 & 19.52 & 0.00 & 86 & 19.49 & 0.01 & 0.00 & 10.39 & 0.01 & 0.00 & 10.39 & 0.00 & 0.00 & 0.00 \\
\hline MI & 04050004 & Upper Grand & 1,730 & 100 & 566.357 & 373.64 & 56.02 & 0.11 & 150 & 192.72 & 16.63 & 0.00 & 86 & 27.15 & 0.00 & 190.90 & $2,480.98$ & 0.00 & 190.90 & $2,480.98$ & 0.00 & 0.00 & 0.00 \\
\hline MI & 04050005 & Maple & 924 & 100 & 69.158 & 22.22 & 2.46 & 0.00 & 111 & 46.94 & 4.05 & 0.00 & 86 & 1.60 & 0.00 & 0.00 & 0.00 & 0.00 & 0.00 & 0.00 & 0.00 & 0.00 & 0.00 \\
\hline MI & 04050006 & Lower Grand & 1,990 & 100 & 802.359 & 538.44 & 15.51 & 0.00 & 123 & 263.92 & 22.77 & 0.00 & 86 & 39.25 & 0.00 & 45.48 & 484.38 & 0.00 & 45.48 & 484.38 & 0.00 & 0.00 & 0.00 \\
\hline MI & 04050007 & Thornapple & 874 & 100 & 93.403 & 35.50 & 4.06 & 0.00 & 114 & 57.90 & 5.00 & 0.00 & 86 & 3.18 & 0.00 & 0.00 & 0.00 & 0.00 & 0.00 & 0.00 & 0.00 & 0.00 & 0.00 \\
\hline MI & 04060101 & $\begin{array}{l}\text { Pere Marquette- } \\
\text { White }\end{array}$ & 2,100 & 100 & 165.436 & 65.48 & 4.03 & 0.00 & 244 & 9.95 & 8.63 & 0.00 & 86 & 5.44 & 0.00 & 0.00 & 0.00 & 0.00 & 0.00 & 0.00 & 0.00 & 0.00 & 0.00 \\
\hline MI & 04060102 & Muskegon & 2,680 & 100 & 237.836 & 99.83 & 10.12 & 0.00 & 176 & 138.01 & 11.91 & 0.00 & 86 & 6.82 & 0.67 & 0.00 & $2,283.51$ & 0.67 & 261.66 & $2,283.51$ & 0.00 & 0.00 & 0.00 \\
\hline MI & 04060103 & Manistee & 1,970 & 100 & 54.802 & 11.61 & 2.21 & 0.00 & 190 & 43.19 & 3.73 & 0.00 & 86 & 0.86 & 0.00 & 0.00 & 478.49 & 0.00 & 1.20 & 478.49 & 0.00 & 0.00 & 0.00 \\
\hline MI & 04060104 & Betsie-Platte & 819 & 100 & 51.238 & 9.78 & 1.53 & 0.00 & 156 & 41.46 & 3.58 & 0.00 & 86 & 0.85 & 0.00 & 0.00 & 0.00 & 0.00 & 0.00 & 0.00 & 0.00 & 0.00 & 0.00 \\
\hline MI & 04060105 & $\begin{array}{l}\text { Boardman- } \\
\quad \text { Charlevoix }\end{array}$ & 1,650 & 100 & 152.899 & 69.60 & 9.12 & 0.00 & 221 & 83.30 & 7.19 & 0.00 & 86 & 4.92 & 0.00 & 0.00 & 0.00 & 0.00 & 0.00 & 0.00 & 0.00 & 0.00 & 0.00 \\
\hline MI & 04060106 & Manistique & 1,480 & 100 & 11.895 & 4.54 & 0.06 & 0.42 & 106 & 7.35 & 0.63 & 0.00 & 86 & 0.44 & 0.00 & 0.00 & 0.00 & 0.00 & 0.00 & 0.00 & 0.00 & 0.00 & 0.00 \\
\hline MI & 04060107 & $\begin{array}{l}\text { Brevoort- } \\
\text { Millecoq }\end{array}$ & 578 & 100 & 4.557 & 0.05 & 0.00 & 0.00 & 0 & 4.51 & 0.39 & 0.00 & 87 & 0.00 & 0.00 & 0.00 & 0.00 & 0.00 & 0.00 & 0.00 & 0.00 & 0.00 & 0.00 \\
\hline MI & 04070001 & St. Marys & 85 & 100 & 28 & 22.5 & 1. & 0.00 & 133 & 5.90 & 0. & 0.00 & 86 & 1.64 & 0. & 0.00 & 0.00 & 0.00 & 0.00 & 0.00 & 0.00 & 0.00 & 0.00 \\
\hline MI & 04070002 & Carp-Pine & 641 & 100 & 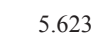 & 3.66 & 0.04 & 0.00 & 347 & 1.96 & 0.17 & 0.00 & 87 & 0.22 & 0.00 & 0.00 & 0.00 & 0.00 & 0.00 & 0.00 & 0.00 & 0.00 & 0.00 \\
\hline MI & 04070003 & $\begin{array}{l}\text { Lone Lake- } \\
\text { Ocqueoc }\end{array}$ & 81 & 1 & 3 & 4.85 & 0 & 0 & 10 & 82 & 2 & 0.00 & 8 & 0.37 & 0 & 0.00 & 00 & 0.00 & 0.00 & 0.00 & 0.00 & 0.00 & 0.00 \\
\hline MI & 04070004 & Cheboygan & 918 & 100 & 41.461 & 7.49 & 1.00 & 0.00 & 134 & 33.97 & 2.93 & 0.00 & 86 & 0.78 & 0.00 & 0.00 & 0.00 & 0.00 & 0.00 & 0.00 & 0.00 & 0.00 & 0.00 \\
\hline MI & 04070005 & Black & 618 & 100 & 6.814 & 1.48 & 0.23 & 0.00 & 155 & 5.33 & 0.46 & 0.00 & 86 & 0.17 & 0.00 & 0.00 & 0.60 & 0.00 & 0.00 & 0.60 & 0.00 & 0.00 & 0.00 \\
\hline MI & 04070006 & Thunder Ba & 1,270 & 100 & 31.136 & 17.64 & 0.71 & 0.00 & 162 & 13.49 & 1.16 & 0.00 & 86 & 1.21 & 0.00 & 0.00 & 294.03 & 0.00 & 110.16 & 294.03 & 0.00 & 0.00 & 0.00 \\
\hline MI & 04070007 & Au Sable & 2,000 & 100 & 58.742 & 18.61 & 2.17 & 0.00 & 120 & 40.13 & 3.46 & 0.00 & 86 & 1.08 & 0.89 & 0.00 & 398.81 & 0.89 & 0.00 & 398.81 & 0.00 & 0.00 & 0.00 \\
\hline MI & 04080101 & Au Gres-Rifle & 1,030 & 100 & 44.500 & 14.43 & 0.38 & 0.00 & 2,410 & 30.07 & 2.60 & 0.00 & 86 & 1.04 & 0.00 & 0.00 & 0.00 & 0.00 & 0.00 & 0.00 & 0.00 & 0.00 & 0.00 \\
\hline MI & 04080102 & Kawkawlin-Pine & 503 & 100 & 57.623 & 8.85 & 0.02 & 0.00 & 14 & 48.78 & 4.21 & 0.00 & 86 & 3.15 & 0.00 & 0.00 & 0.00 & 0.00 & 0.00 & 0.00 & 0.00 & 0.00 & 0.00 \\
\hline MI & 04080103 & $\begin{array}{l}\text { Pigeon- } \\
\quad \text { Wiscoggin }\end{array}$ & 853 & 100 & 45.597 & 16.21 & 1.04 & 0.00 & 93 & 29.39 & 2.54 & 0.00 & 86 & 1.25 & 0.00 & 0.00 & 0.00 & 0.00 & 0.00 & 0.00 & 0.00 & 0.00 & 0.00 \\
\hline MI & 04080104 & Birch-Willow & 572 & 100 & 31.946 & 19.71 & 0.30 & 0.00 & 8,229 & 12.24 & 1.06 & 0.00 & 87 & 1.45 & 0.00 & 0.00 & 392.81 & 0.00 & 84.03 & 392.81 & 0.00 & 0.00 & 0.00 \\
\hline MI & 04080201 & Tittabawassee & 1,430 & 100 & 162.325 & 72.53 & 1.65 & 0.00 & 24 & 89.79 & 7.75 & 0.00 & 86 & 7.39 & 0.00 & 4.84 & $6,301.70$ & 0.00 & 4.84 & $6,301.70$ & 0.00 & 0.00 & 0.00 \\
\hline MI & 04080202 & Pine & 1,040 & 100 & 111.236 & 50.66 & 4.65 & 0.68 & 105 & 60.58 & 5.23 & 0.00 & 86 & 4.04 & 0.12 & 0.00 & 5.64 & 0.12 & 0.00 & 5.64 & 0.00 & 0.00 & 0.00 \\
\hline
\end{tabular}


Appendix 1B. Estimates of Withdrawals and Other Elements of Water Use by State.-Continued

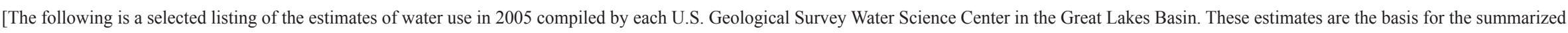
findings presented elsewhere in this report. The compiled values from selected New York watersheds (8-digit HUCs) are preliminary; these values are identified by bold typeface. A complete listing of estimates,

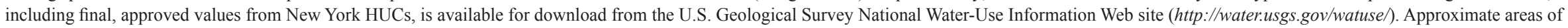

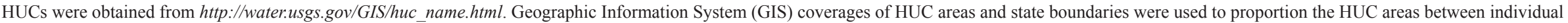
Great Lakes States. Column tags are defined in appendix 1A. Data Dictionary; NA, not applicable; NR, not reported; NULL, value unknown, not reported]

\begin{tabular}{|c|c|c|c|c|c|c|c|c|c|c|c|c|c|c|c|c|c|c|c|c|c|c|c|}
\hline STATE & HUC8Code & HUC8Name & $\begin{array}{c}\text { IN- } \\
\text { WGWFr }\end{array}$ & $\begin{array}{c}\text { IN- } \\
\text { WSWFr }\end{array}$ & $\begin{array}{c}\text { IN- } \\
\text { RecWW }\end{array}$ & $\begin{array}{c}\text { MI- } \\
\text { WGWFr }\end{array}$ & $\begin{array}{c}\text { MI- } \\
\text { WGWSa }\end{array}$ & $\begin{array}{c}\text { MI- } \\
\text { WSWFr }\end{array}$ & $\begin{array}{c}\text { MI- } \\
\text { WSWSa }\end{array}$ & $\begin{array}{c}\text { IG- } \\
\text { WGWFr }\end{array}$ & $\begin{array}{c}\text { IG- } \\
\text { WSWFr }\end{array}$ & $\begin{array}{c}\text { IT- } \\
\text { WGWFr }\end{array}$ & $\begin{array}{c}\text { IT- } \\
\text { WSWFr }\end{array}$ & $\begin{array}{l}\text { IT- } \\
\text { IrSpr }\end{array}$ & $\begin{array}{l}\text { IT- } \\
\text { IrMic }\end{array}$ & $\begin{array}{l}\text { IT- } \\
\text { IrSur }\end{array}$ & $\begin{array}{c}\text { IT- } \\
\text { RecWW }\end{array}$ & $\begin{array}{c}\text { LA- } \\
\text { WGWFr }\end{array}$ & $\begin{array}{c}\text { LA- } \\
\text { WSWFr }\end{array}$ & $\begin{array}{c}\text { LS- } \\
\text { WGWFr }\end{array}$ & $\begin{array}{c}\text { LS- } \\
\text { WSWFr }\end{array}$ & $\begin{array}{c}\text { CO- } \\
\text { WGWFr }\end{array}$ & $\begin{array}{c}\text { Co- } \\
\text { WSWFr }\end{array}$ \\
\hline MI & 04040001 & $\begin{array}{l}\text { Little Calumet- } \\
\text { Galien }\end{array}$ & 0.00 & 0.00 & NULL & 0.00 & 0.00 & 0.15 & 0.00 & 0.02 & 0.12 & 0.21 & 0.27 & 0.53 & 0.00 & 0.00 & NULL & 0.00 & 0.00 & 0.04 & 0.00 & NR & NR \\
\hline MI & 04050001 & St. Joseph & 11.20 & 0.29 & NULL & 0.01 & 0.00 & 2.87 & 0.00 & 0.81 & 1.01 & 96.14 & 47.63 & 230.92 & 5.47 & 3.08 & NULL & 0.05 & 0.00 & 1.49 & 0.17 & NR & NR \\
\hline MI & 04050002 & Black-Macatawa & 0.17 & 6.66 & NULL & 0.01 & 0.00 & 1.10 & 0.00 & 0.21 & 0.21 & 6.76 & 4.02 & 14.40 & 0.34 & 0.19 & NULL & 0.03 & 0.00 & 0.73 & 0.08 & NR & NR \\
\hline MI & 04050003 & Kalamazoo & 35.55 & 9.32 & NULL & 0.00 & 0.00 & 3.72 & 0.00 & 1.63 & 0.71 & 7.68 & 8.57 & 26.39 & 0.57 & 0.32 & NULL & 0.01 & 0.04 & 1.69 & 0.19 & NR & NR \\
\hline MI & 04050004 & Upper Grand & 0.79 & 0.02 & NULL & 0.04 & 0.00 & 2.12 & 0.00 & 0.81 & 0.34 & 2.90 & 2.08 & 7.87 & 0.14 & 0.08 & NULL & 0.02 & 0.17 & 0.94 & 0.11 & NR & NR \\
\hline MI & 04050005 & Maple & 0.82 & 0.00 & NULL & 0.00 & 0.00 & 0.88 & 0.00 & 0.07 & 0.03 & 2.40 & 1.26 & 5.70 & 0.13 & 0.07 & NULL & 0.00 & 0.00 & 0.92 & 0.11 & NR & NR \\
\hline MI & 04050006 & Lower Grand & 1.78 & 1.72 & NULL & 0.00 & 0.00 & 2.03 & 0.00 & 1.40 & 0.70 & 28.85 & 8.17 & 56.85 & 1.30 & 0.73 & NULL & 0.02 & 0.36 & 1.82 & 0.20 & NR & NR \\
\hline MI & 04050007 & Thornapple & 0.17 & 0.47 & NULL & 0.00 & 0.00 & 0.75 & 0.00 & 0.21 & 0.19 & 1.10 & 1.06 & 3.58 & 0.07 & 0.05 & NULL & 0.00 & 0.00 & 0.51 & 0.05 & NR & NR \\
\hline MI & 04060101 & $\begin{array}{l}\text { Pere Marquette- } \\
\text { White }\end{array}$ & 1.86 & 0.00 & NULL & 0.00 & 0.00 & 0.30 & 0.00 & 0.96 & 0.21 & 3.47 & 1.83 & 8.43 & 0.18 & 0.10 & NULL & 0.07 & 1.11 & 0.73 & 0.07 & NR & NR \\
\hline MI & 04060102 & Muskegon & 4.64 & 4.19 & NULL & 0.01 & 0.44 & 1.28 & 0.00 & 1.34 & 0.49 & 15.96 & 4.15 & 30.79 & 0.69 & 0.39 & NULL & 0.06 & 6.17 & 1.14 & 0.12 & NR & NR \\
\hline MI & 04060103 & Manistee & 3.25 & 18.78 & NULL & 0.00 & 0.10 & 0.64 & 0.00 & 0.46 & 0.02 & 2.20 & 0.41 & 4.18 & 0.08 & 0.05 & NULL & 0.00 & 3.57 & 0.23 & 0.01 & NR & NR \\
\hline MI & 04060104 & Betsie-Platte & 0.76 & 0.01 & NULL & 0.13 & 0.00 & 0.67 & 0.00 & 0.80 & 0.19 & 1.60 & 0.30 & 2.36 & 0.03 & 0.02 & NULL & 0.00 & 0.18 & 0.07 & 0.00 & NR & NR \\
\hline MI & 04060105 & $\begin{array}{l}\text { Boardman- } \\
\text { Charlevoix }\end{array}$ & 11.35 & 0.00 & NULL & 0.04 & 0.03 & 1.19 & 0.00 & 1.85 & 0.28 & 4.46 & 0.43 & 7.40 & 0.11 & 0.07 & NULL & 0.01 & 32.41 & 0.17 & 0.00 & NR & NR \\
\hline MI & 04060106 & Manistique & 0.00 & 5.70 & NULL & 0.00 & 0.13 & 0.97 & 0.00 & 0.00 & 0.10 & 0.01 & 0.12 & 0.07 & 0.00 & 0.00 & NULL & 0.00 & 0.00 & 0.02 & 0.00 & NR & NR \\
\hline MI & 04060107 & $\begin{array}{l}\text { Brevoort- } \\
\text { Millecoquins }\end{array}$ & 0.00 & 0.00 & NULL & 0.00 & 0.01 & 0.50 & 0.00 & 0.08 & 0.00 & 0.08 & 0.00 & 0.02 & 0.00 & 0.00 & NULL & 0.00 & 0.00 & 0.02 & 0.00 & NR & NR \\
\hline MI & 04070001 & St. Marys & 0.05 & 0.00 & NULL & 0.01 & 0.00 & 0.26 & 0.00 & 0.03 & 0.02 & 0.04 & 0.04 & 0.17 & 0.00 & 0.00 & NULL & 0.44 & 0.16 & 0.02 & 0.00 & NR & NR \\
\hline MI & 04070002 & Carp-Pine & 0.02 & 0.00 & NULL & 0.01 & 0.00 & 0.48 & 0.00 & 0.00 & 0.00 & 0.00 & 0.00 & 0.03 & 0.00 & 0.00 & NULL & 0.37 & 0.13 & 0.03 & 0.00 & NR & NR \\
\hline MI & 04070003 & $\begin{array}{l}\text { Lone Lake- } \\
\text { Ocqueoc }\end{array}$ & 0.01 & 0.00 & NULL & 0.00 & 0.00 & 1.58 & 0.00 & 0. & $0 .($ & 0.42 & 0.25 & 1.14 & 0.02 & 0.01 & NULL & 0.00 & 0.52 & 0.10 & 0.01 & NR & NR \\
\hline MI & 04070004 & Cheboygan & 0.07 & 0.25 & NULL & 0.02 & 0.00 & 0.21 & 0.00 & 0.59 & 0.02 & 0.59 & 0.02 & 0.82 & 0.00 & 0.00 & NULL & 0.01 & 0.41 & 0.09 & 0.00 & NR & NR \\
\hline MI & 04070005 & Black & 0.00 & 0.00 & NULL & 0.01 & 0.00 & 0.61 & 0.00 & 0.08 & 0.00 & 0.09 & 0.02 & 0.06 & 0.00 & 0.00 & NULL & 0.00 & 0.00 & 0.05 & 0.00 & NR & NR \\
\hline MI & 04070006 & Thunder Bay & 0.00 & 4.04 & NULL & 0.01 & 0.00 & 1.09 & 0.00 & 0.13 & 0.31 & 0.72 & 0.50 & 0.51 & 0.00 & 0.00 & NULL & 0.01 & 1.45 & 0.17 & 0.01 & NR & NR \\
\hline MI & 04070007 & Au Sable & 0.55 & 0.07 & NULL & 0.01 & 0.03 & 0.27 & 0.00 & 0.82 & 0.59 & 1.04 & 0.60 & 1.84 & 0.01 & 0.01 & NULL & 0.06 & 2.12 & 0.17 & 0.01 & NR & NR \\
\hline MI & 04080101 & Au Gres-Rifle & 0.00 & 0.09 & NULL & 0.02 & 0.08 & 0.37 & 0.00 & 0.39 & 0.17 & 0.57 & 0.23 & 0.52 & 0.00 & 0.00 & NULL & 0.17 & 0.52 & 0.28 & 0.04 & NR & NR \\
\hline MI & 04080102 & Kawkawlin-Pine & 0.19 & 0.00 & NULL & 0.00 & 0.00 & 0.02 & 0.00 & 0.08 & 0.04 & 0.16 & 0.75 & 1.75 & 0.03 & 0.02 & NULL & 0.00 & 0.00 & 0.11 & 0.00 & NR & NR \\
\hline MI & 04080103 & $\begin{array}{l}\text { Pigeon- } \\
\text { Wiscoggin }\end{array}$ & 0.00 & 0.00 & NULL & 0.00 & 0.00 & 0.21 & 0.00 & 0.06 & 0.09 & 1.17 & 1.29 & 6.24 & 0.15 & 0.08 & NULL & 0.00 & 0.00 & 0.78 & 0.09 & NR & NR \\
\hline MI & 04080104 & Birch-Willow & 0.04 & 0.00 & NULL & 0.00 & 0.00 & 0.25 & 0.00 & 0.14 & 0.00 & 0.18 & 0.06 & 0.29 & 0.00 & 0.00 & NULL & 0.02 & 0.00 & 0.59 & 0.07 & NR & NR \\
\hline MI & 04080201 & Tittabawassee & 0.14 & 6.00 & NULL & 0.00 & 0.00 & 0.37 & 0.00 & 0.10 & 0.21 & 0.21 & 0.26 & 0.72 & 0.02 & 0.00 & NULL & 0.03 & 0.05 & 0.35 & 0.04 & NR & NR \\
\hline MI & 04080202 & Pine & 0.57 & 0.00 & NULL & 0.00 & 0.03 & 0.38 & 0.00 & 0.04 & 0.56 & 3.53 & 1.84 & 8.86 & 0.20 & 0.12 & NULL & 0.00 & 1.80 & 0.61 & 0.07 & NR & NR \\
\hline
\end{tabular}




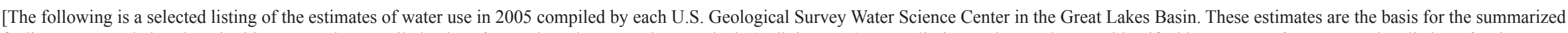
findings presented elsewhere in this report. The compiled values from selected New York watersheds (8-digit HUCs) are preliminary; these values are identified by bold typeface. A complete listing of estimates, including final, approved values from New York HUCs, is available for download from the U.S. Geological Survey National Water-Use Information Web site (http://water.usgs.gov/watuse/). Approximate areas

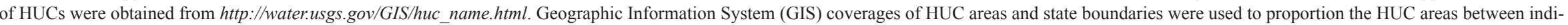
vidual Great Lakes States. Column tags are defined in appendix 1A. Data Dictionary; NA, not applicable; NR, not reported; NULL, value unknown, not reported]

\begin{tabular}{|c|c|c|c|c|c|c|c|c|c|c|c|c|c|c|c|c|c|c|c|c|c|c|c|}
\hline STATE & HUC8Code & HUC8Name & AREA & AREA\% $\%$ & $\begin{array}{l}\text { TP-Total- } \\
\text { Pop }\end{array}$ & $\begin{array}{l}\text { PS- } \\
\text { TOPop }\end{array}$ & $\begin{array}{c}\text { PS- } \\
\text { WGWFr }\end{array}$ & $\begin{array}{c}\text { PS- } \\
\text { WSWFr }\end{array}$ & $\begin{array}{l}\text { PS- } \\
\text { PrCap }\end{array}$ & $\begin{array}{l}\text { DO- } \\
\text { SSPop }\end{array}$ & $\begin{array}{c}\text { DO- } \\
\text { WGWFr }\end{array}$ & $\begin{array}{c}\text { DO- } \\
\text { WSWFr }\end{array}$ & $\begin{array}{l}\text { DO- } \\
\text { SSPCp }\end{array}$ & $\begin{array}{l}\text { DO- } \\
\text { PSDel }\end{array}$ & $\begin{array}{c}\text { PT- } \\
\text { WGWFr }\end{array}$ & $\begin{array}{c}\text { PT- } \\
\text { WSWFr }\end{array}$ & $\begin{array}{l}\text { PT- } \\
\text { Power }\end{array}$ & $\begin{array}{c}\text { P0- } \\
\text { WGWFr }\end{array}$ & $\begin{array}{c}\text { PO- } \\
\text { WSWFr }\end{array}$ & $\begin{array}{l}\text { P0- } \\
\text { Power }\end{array}$ & $\begin{array}{c}\text { PC- } \\
\text { WGWFr }\end{array}$ & $\begin{array}{c}\text { PC- } \\
\text { WSWFr }\end{array}$ & $\begin{array}{l}\text { PC- } \\
\text { Power }\end{array}$ \\
\hline MI & 04080203 & Shiawassee & 1,220 & 100 & 198.153 & 78.86 & 10.99 & 0.00 & 139 & 119.29 & 10.29 & 0.00 & 86 & 7.53 & 0.00 & 0.00 & 0.00 & 0.00 & 0.00 & 0.00 & 0.00 & 0.00 & 0.00 \\
\hline MI & 04080204 & Flint & 1,340 & 100 & 519.051 & 316.72 & 4.00 & 0.00 & 13 & 202.33 & 17.46 & 0.00 & 86 & 24.78 & 0.21 & 0.00 & 233.59 & 0.21 & 0.00 & 233.59 & 0.00 & 0.00 & 0.00 \\
\hline MI & 04080205 & Cass & 881 & 100 & 70.655 & 34.77 & 2.80 & 0.00 & 81 & 35.89 & 3.10 & 0.00 & 86 & 2.45 & 0.00 & 0.00 & 0.00 & 0.00 & 0.00 & 0.00 & 0.00 & 0.00 & 0.00 \\
\hline MI & 04080206 & Saginaw & 250 & 100 & 167.077 & 135.72 & 0.00 & 0.00 & 165 & 31.36 & 2.71 & 0.00 & 86 & 10.83 & 0.00 & 0.00 & $6,287.73$ & 0.00 & 615.39 & $6,287.73$ & 0.00 & 0.00 & 0.00 \\
\hline MI & 04090001 & St. Clair & 1,210 & 100 & 175.839 & 99.79 & 2.11 & 0.00 & 157 & 76.04 & 6.56 & 0.00 & 86 & 8.00 & 0.00 & 0.00 & $16,700.70$ & 0.00 & $1,472.83$ & $16,700.70$ & 0.00 & 0.00 & 0.00 \\
\hline MI & 04090002 & Lake St. Clair & 413 & 100 & 619.321 & 585.50 & 0.01 & 0.00 & 11 & 33.82 & 2.91 & 0.00 & 86 & 49.64 & 0.00 & 0.00 & 0.00 & 0.00 & 0.00 & 0.00 & 0.00 & 0.00 & 0.00 \\
\hline MI & 04090003 & Clinton & 742 & 100 & $1,069.471$ & 933.44 & 18.98 & 0.00 & 28 & 136.03 & 11.74 & 0.00 & 86 & 67.02 & 0.00 & 0.00 & 0.00 & 0.00 & 0.00 & 0.00 & 0.00 & 0.00 & 0.00 \\
\hline MI & 04090004 & Detroit & 685 & 100 & $2,105.501$ & $2,104.90$ & 0.86 & 0.00 & 215 & 0.60 & 0.05 & 0.00 & 83 & 170.62 & 0.00 & 162.10 & $10,465.14$ & 0.00 & $1,112.24$ & $10,465.14$ & 0.00 & 0.00 & 0.00 \\
\hline MI & 04090005 & Huron & 909 & 100 & 602.781 & 465.50 & 13.81 & 13.42 & 59 & 137.28 & 11.85 & 0.00 & 86 & 35.01 & 0.00 & 0.00 & 0.00 & 0.00 & 0.00 & 0.00 & 0.00 & 0.00 & 0.00 \\
\hline MI & 04100001 & Ottawa-Stony & 541 & 79 & 163.004 & 12.74 & 0.06 & 0.00 & 278 & 150.26 & 12.97 & 0.00 & 86 & 2.02 & 0.09 & 0.00 & $31,186.30$ & 0.09 & $1,808.34$ & $31,186.30$ & 0.00 & 0.00 & 0.00 \\
\hline MI & 04100002 & Raisin & 1,046 & 98 & 172.057 & 150.37 & 7.04 & 2.89 & 135 & 21.69 & 1.87 & 0.00 & 86 & 9.09 & 0.00 & 0.00 & 0.00 & 0.00 & 0.00 & 0.00 & 0.00 & 0.00 & 0.00 \\
\hline MI & 04100003 & St. Joseph & 251 & 24 & 11.035 & 0.86 & 0.07 & 0.00 & 81 & 10.17 & 0.88 & 0.00 & 87 & 0.06 & 0.00 & 0.00 & 0.00 & 0.00 & 0.00 & 0.00 & 0.00 & 0.00 & 0.00 \\
\hline MI & 04100006 & Tiffin & 225 & 29 & 17.925 & 6.63 & 0.72 & 0.00 & 109 & 11.29 & 0.97 & 0.00 & 86 & 0.56 & 0.00 & 0.00 & 0.00 & 0.00 & 0.00 & 0.00 & 0.00 & 0.00 & 0.00 \\
\hline MI & 04020300 & Lake Superior & 16,448 & 78 & 0.000 & 0.00 & 0.00 & 4.18 & 0 & 0.00 & 0.00 & 0.00 & 0 & 0.00 & 0.00 & 270.13 & 0.00 & 0.00 & 0.00 & 0.00 & 0.00 & 0.00 & 0.00 \\
\hline MI & 04060200 & Lake Michigan & 13,179 & 59 & 0.564 & 0.00 & 0.00 & 143.51 & 0 & 0.56 & 0.05 & 0.00 & 89 & 0.00 & 0.00 & 3430.45 & 0.00 & 0.00 & 0.00 & 0.00 & 0.00 & 0.00 & 0.00 \\
\hline MI & 04080300 & Lake Huron & 8,920 & 100 & 2.274 & 0.00 & 0.00 & 224.75 & 0 & 2.27 & 0.20 & 0.00 & 88 & 0.00 & 0.00 & 809.58 & 0.00 & 0.00 & 0.00 & 0.00 & 0.00 & 0.00 & 0.00 \\
\hline MI & 04120200 & Lake Erie & 118 & 2 & 0.890 & 0.00 & 0.00 & 492.65 & 0 & 0.89 & 0.08 & 0.00 & 90 & 0.00 & 0.00 & 4231.31 & 0.00 & 0.00 & 0.00 & 0.00 & 0.00 & 0.00 & 0.00 \\
\hline $\mathrm{MN}$ & 04010101 & Baptism-Brule & 1,620 & 100 & 635 & 1.76 & 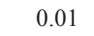 & 0.00 & 148 & 4.88 & 0. & 0.00 & 70 & 0.07 & 0.00 & 0.00 & 0.00 & 0.00 & 0.00 & 0.00 & 0.00 & 0.00 & 0.00 \\
\hline MN & 04010102 & Beaver-Lester & 635 & 100 & 67.555 & 63.90 & 0.0 & 0.00 & 451 & .66 & 0.26 & 0.00 & 71 & 2.95 & 0.00 & 0.00 & 0.00 & 0.00 & 0.00 & 0.00 & 0.00 & 0.00 & 0.00 \\
\hline MN & 04010201 & St. Louis & 2,939 & 98 & 126.477 & 103.45 & 5.98 & 5.23 & 108 & 23.03 & 1.61 & 0.00 & 70 & 5.37 & 0.11 & 190.23 & 863.03 & 0.00 & 190.23 & 815.69 & 0.11 & 0.00 & 47.34 \\
\hline MN & 04010202 & Cloquet & 796 & 100 & 10.304 & 0.00 & 0.00 & 0.00 & 0 & 10.30 & 0.72 & 0.00 & 70 & 0.00 & 0.00 & 0.00 & 0.00 & 0.00 & 0.00 & 0.00 & 0.00 & 0.00 & 0.00 \\
\hline MN & 04010301 & Beartrap-Nemadji & 263 & 14 & 2.745 & 0.00 & 0.00 & 0.00 & 0 & 2.74 & 0.19 & 0.00 & 69 & 0.00 & 0.00 & 0.00 & 0.00 & 0.00 & 0.00 & 0.00 & 0.00 & 0.00 & 0.00 \\
\hline MN & 04020300 & Lake Superior & 2,595 & 12 & 1.378 & 0.00 & 0.00 & 29.07 & 0 & 1.38 & 0.10 & 0.00 & 73 & 0.00 & 0.00 & 0.00 & 0.00 & 0.00 & 0.00 & 0.00 & 0.00 & 0.00 & 0.00 \\
\hline NY & 04120101 & $\begin{array}{r}\text { Chautauqua- } \\
\text { Conneaut }\end{array}$ & 311 & 36 & 5 & 32.89 & 0.08 & 2 & 78 & 50 & 1.39 & 0.00 & 7 & 3.26 & 0 & 0.00 & 0.00 & 0.00 & 0.00 & 0.00 & 0.00 & 0.00 & 0.00 \\
\hline NY & 04120102 & Cattaraugus & 548 & 100 & 43.613 & 33.41 & 2.35 & 0.72 & 92 & 10.20 & 0.9 & 0.00 & 75 & 3.47 & 0.00 & 0.00 & 0.00 & 0.00 & 0.00 & 0.00 & 0.00 & 0.00 & 0.00 \\
\hline NY & 04120103 & $\begin{array}{l}\text { Buffalo- } \\
\quad \text { Eighteenmile }\end{array}$ & 732 & 100 & 500.252 & 443.98 & 0.37 & 0.00 & 1 & 56.27 & 4.22 & 0.00 & 75 & 53.41 & 0.00 & 0.00 & 0.00 & 0.00 & 0.00 & 0.00 & 0.00 & 0.00 & 0.00 \\
\hline NY & 04120104 & Niagara & 774 & 100 & 609.875 & 544.08 & 0.42 & 17.77 & 33 & 65.79 & 4.93 & 0.00 & 75 & 63.85 & 0.00 & 595.13 & $2,692.36$ & 0.00 & 595.13 & $2,692.36$ & 0.00 & 0.00 & 0.00 \\
\hline NY & 04130001 & $\begin{array}{l}\text { Oak Orchard- } \\
\text { Twelvemile }\end{array}$ & 1,040 & 100 & 81.246 & 240.75 & 0.45 & 39.08 & 164 & 0.49 & 3.03 & 0.00 & 75 & 24.08 & 0.00 & 0.00 & 0.00 & 0.00 & 0.00 & 0.00 & 0.00 & 0.00 & 0.00 \\
\hline NY & 04130002 & Upper Genesee & 1,339 & 94 & 69.615 & 49.11 & 2.25 & 2.46 & 132 & 20.50 & 1.54 & 0.00 & 75 & 4.89 & 0.00 & 0.00 & 0.00 & 0.00 & 0.00 & 0.00 & 0.00 & 0.00 & 0.00 \\
\hline
\end{tabular}


Appendix 1B. Estimates of Withdrawals and Other Elements of Water Use by State.-Continued

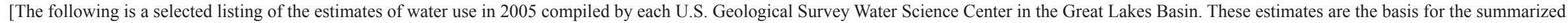

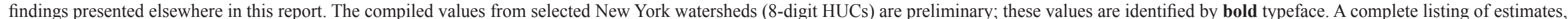

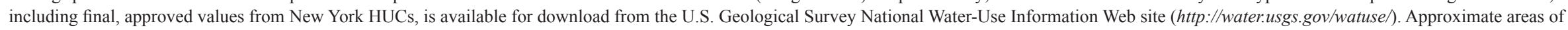

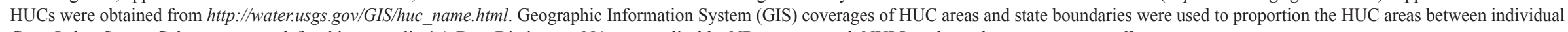
Great Lakes States. Column tags are defined in appendix 1A. Data Dictionary; NA, not applicable; NR, not reported; NULL, value unknown, not reported]

\begin{tabular}{|c|c|c|c|c|c|c|c|c|c|c|c|c|c|c|c|c|c|c|c|c|c|c|c|}
\hline STATE & HUC8Code & HUC & $\begin{array}{l}\text { IN- } \\
\text { WGWFr }\end{array}$ & $\begin{array}{c}\text { IN- } \\
\text { WSWFr }\end{array}$ & $\begin{array}{c}\text { IN- } \\
\text { RecWW }\end{array}$ & $\begin{array}{c}\text { MI- } \\
\text { WGWFr }\end{array}$ & $\begin{array}{c}\text { MI- } \\
\text { WGWSa }\end{array}$ & $\begin{array}{c}\text { MI- } \\
\text { WSWFr }\end{array}$ & $\begin{array}{c}\text { MI- } \\
\text { WSWSa }\end{array}$ & $\begin{array}{c}\text { IG- } \\
\text { WGWFr }\end{array}$ & $\begin{array}{c}\text { IG- } \\
\text { WSWFr }\end{array}$ & $\begin{array}{c}\text { IT- } \\
\text { WGWFr }\end{array}$ & $\begin{array}{c}\text { IT- } \\
\text { WSWFr }\end{array}$ & $\begin{array}{l}\text { IT- } \\
\text { IrSpr }\end{array}$ & $\begin{array}{l}\text { IT- } \\
\text { IrMic }\end{array}$ & $\begin{array}{l}\text { IT- } \\
\text { IrSur }\end{array}$ & $\begin{array}{c}\text { IT- } \\
\text { RecWW }\end{array}$ & $\begin{array}{c}\text { LA- } \\
\text { WGWFr }\end{array}$ & $\begin{array}{c}\text { LA- } \\
\text { WSWFr }\end{array}$ & $\begin{array}{c}\text { LS- } \\
\text { WGWFr }\end{array}$ & $\begin{array}{c}\text { LS- } \\
\text { WSWFr }\end{array}$ & $\begin{array}{c}\text { CO- } \\
\text { WGWFr }\end{array}$ & $\begin{array}{c}\text { Co- } \\
\text { WSWFr }\end{array}$ \\
\hline MI & 04080203 & Shiawassee & 0.21 & 0.00 & NULL & 0.11 & 0.00 & 2.21 & 0.00 & 0.73 & 0.72 & 2.63 & 2.47 & 5.71 & 0.10 & 0.07 & NULL & 0.00 & 0.00 & 0.37 & 0.03 & NR & NR \\
\hline MI & 04080204 & Flint & 0.13 & 0.00 & NULL & 0.16 & 0.00 & 1.60 & 0.00 & 0.25 & 0.76 & 1.43 & 1.52 & 4.05 & 0.06 & 0.04 & NULL & 0.00 & 0.00 & 0.36 & 0.04 & NR & NR \\
\hline MI & 04080205 & Cass & 0.00 & 0.08 & NULL & 0.00 & 0.00 & 0.37 & 0.00 & 0.10 & 0.16 & 0.82 & 0.20 & 3.01 & 0.06 & 0.04 & NULL & 0.03 & 0.00 & 0.51 & 0.06 & NR & NR \\
\hline MI & 04080206 & Saginaw & 0.00 & 2.65 & NULL & 0.00 & 0.00 & 0.01 & 0.00 & 0.01 & 0.04 & 0.27 & 0.13 & 1.08 & 0.02 & 0.01 & NULL & 0.00 & 0.00 & 0.06 & 0.00 & NR & NR \\
\hline MI & 04090001 & St. Clair & 0.08 & 0.00 & NULL & 0.00 & 0.00 & 0.82 & 0.00 & 0.11 & 0.15 & 0.78 & 1.11 & 2.91 & 0.05 & 0.03 & NULL & 0.04 & 0.00 & 0.58 & 0.07 & NR & NR \\
\hline MI & 04090002 & Lake St. Clair & 0.00 & 0.00 & NULL & 0.00 & 0.01 & 0.24 & 0.00 & 0.19 & 0.16 & 0.28 & 0.20 & 0.69 & 0.00 & 0.00 & NULL & 0.01 & 0.00 & 0.03 & 0.00 & NR & NR \\
\hline MI & 04090003 & Clinton & 0.66 & 0.00 & NULL & 0.55 & 0.00 & 2.77 & 0.00 & 1.14 & 2.09 & 1.83 & 3.52 & 7.22 & 0.09 & 0.03 & NULL & 0.02 & 0.00 & 0.07 & 0.01 & NR & NR \\
\hline MI & 04090004 & Detroit & 0.20 & 1.46 & NULL & 0.28 & 0.06 & 2.18 & 0.00 & 0.90 & 1.24 & 1.10 & 1.36 & 3.90 & 0.02 & 0.00 & NULL & 0.02 & 0.08 & 0.04 & 0.00 & NR & NR \\
\hline MI & 04090005 & Huron & 2.98 & 8.80 & NULL & 0.34 & 0.01 & 3.25 & 0.00 & 1.48 & 1.00 & 2.43 & 1.46 & 6.38 & 0.05 & 0.03 & NULL & 0.18 & 0.94 & 0.20 & 0.03 & NR & NR \\
\hline MI & 04100001 & Ottawa-Stony & 8.59 & 0.00 & NULL & 1.50 & 0.01 & 2.25 & 0.00 & 0.74 & 0.02 & 1.40 & 1.74 & 5.21 & 0.10 & 0.06 & NULL & 0.04 & 0.17 & 0.09 & 0.01 & NR & NR \\
\hline MI & 04100002 & Raisin & 1.07 & 1.37 & NULL & 0.69 & 0.00 & 1.75 & 0.00 & 0.35 & 0.17 & 1.15 & 2.34 & 6.52 & 0.15 & 0.08 & NULL & 0.10 & 0.52 & 0.47 & 0.06 & NR & NR \\
\hline MI & 04100003 & St. Joseph & 0.00 & 0.00 & NULL & 0.00 & 0.00 & 0.27 & 0.00 & 0.00 & 0.00 & 0.18 & 0.19 & 0.58 & 0.01 & 0.01 & NULL & 0.00 & 0.00 & 0.23 & 0.02 & NR & NR \\
\hline MI & 04100006 & Tiffin & 0.00 & 0.00 & NULL & 0.04 & 0.00 & 0.24 & 0.00 & 0.10 & 0.00 & 0.33 & 0.55 & 2.13 & 0.05 & 0.03 & NULL & 0.00 & 0.00 & 0.16 & 0.02 & NR & NR \\
\hline MI & 04020300 & Lake Superior & 0.00 & 12.73 & NULL & 0.00 & 0.00 & 0.00 & 0.00 & 0.00 & 0.01 & 0.00 & 0.01 & 0.00 & 0.00 & 0.00 & NULL & 0.00 & 0.00 & 0.00 & 0.00 & NR & NR \\
\hline MI & 04060200 & Lake Michigan & 0.00 & 107.26 & NULL & 0.02 & 0.00 & 0.27 & 0.00 & 0.00 & 0.18 & 0.00 & 2.47 & 0.00 & 0.00 & 0.00 & NULL & 0.00 & 0.00 & 0.01 & 0.00 & NR & NR \\
\hline MI & 04080300 & Lake Huron & 0.00 & 19.55 & NULL & 0.01 & 0.00 & 0.16 & 0.00 & 0.00 & 0.09 & 0.00 & 3.06 & 0.00 & 0.00 & 0.00 & NULL & 0.25 & 0.09 & 0.01 & 0.00 & NR & NR \\
\hline MI & 04120200 & Lake Erie & 0.00 & 287.07 & NULL & 0.00 & 0.00 & 0.00 & 0.00 & 0.00 & 0.12 & 0.00 & 0.42 & 0.00 & 0.00 & 0.00 & NULL & 0.00 & 0.00 & 0.00 & 0.00 & NR & NR \\
\hline $\mathrm{MN}$ & 04010101 & Baptism-Brule & 0.00 & 0.00 & NULL & 0.01 & 0.00 & 0.00 & 0.00 & 0.0 & 0.0 & 0.00 & 0.04 & 0.00 & 0.00 & 0.00 & NULL & 0.00 & 0.36 & 0.0 & 0.00 & 0.00 & 0.26 \\
\hline $\mathrm{MN}$ & 04010102 & Beaver-Lester & 0.00 & 0.00 & NULL & 0.00 & 0.00 & 3.43 & 0.00 & 0.01 & 0.07 & 0.01 & 0.07 & 0.01 & 0.00 & 0.00 & NULL & 0.02 & 0.03 & 0.01 & 0.00 & 0.00 & 0.67 \\
\hline $\mathrm{MN}$ & 04010201 & St. Louis & 0.01 & 6.13 & NULL & 0.01 & 0.00 & 54.78 & 0.00 & 0.00 & 0.26 & 0.00 & 0.26 & 0.00 & 0.00 & 0.00 & NULL & 0.27 & 0.02 & 0.14 & 0.00 & 0.06 & 0.40 \\
\hline $\mathrm{MN}$ & 04010202 & Cloquet & 0.00 & 0.00 & NULL & 0.00 & 0.00 & 0.08 & 0.00 & 0.00 & 0.00 & 0.00 & 0.00 & 0.00 & 0.00 & 0.00 & NULL & 0.06 & 0.01 & 0.02 & 0.00 & 0.00 & 0.00 \\
\hline MN & 04010301 & Beartrap-Nemadji & 0.00 & 0.00 & NULL & 0.00 & 0.00 & 0.00 & 0.00 & 0.00 & 0.00 & 0.00 & 0.02 & 0.02 & 0.00 & 0.00 & NULL & 0.01 & 0.01 & 0.07 & 0.00 & 0.00 & 0.00 \\
\hline $\mathrm{MN}$ & 04020300 & Lake Superior & 0.00 & 1.63 & NULL & 0.00 & 0.00 & 296.45 & 0.00 & 0.00 & 0.00 & 0.00 & 0.00 & 0.00 & 0.00 & 0.00 & NULL & 0.00 & 0.00 & 0.00 & 0.00 & 0.00 & 0.00 \\
\hline NY & 04120101 & $\begin{array}{r}\text { Chautauqua- } \\
\text { Conneaut }\end{array}$ & 0.8 & 0.14 & NULL & 0.01 & 0.00 & 0.6 & 0.00 & 0. & 0. & 0.08 & 0. & 0.37 & 0.08 & 0.00 & NULL & 0.9 & 0. & 0.19 & 0.10 & $\mathrm{NR}$ & $N R$ \\
\hline NY & 04120102 & Cattaraugus & 0.50 & 0.59 & NULL & 0.10 & 0.05 & 0.43 & 0.00 & 0.10 & 0.26 & 0.16 & 0.42 & 0.94 & 0.29 & 0.00 & NULL & 0.48 & 0.48 & 0.31 & 0.17 & NR & NR \\
\hline NY & 04120103 & $\begin{array}{l}\text { Buffalo- } \\
\quad \text { Eighteenmile }\end{array}$ & 0.14 & 10.06 & NULL & 0.13 & 0.03 & 0.60 & 0.00 & 0.30 & 0.80 & 0.46 & 1.23 & 2.67 & 0.79 & 0.00 & NULL & 0.01 & 0.01 & 0.50 & 0.27 & NR & NR \\
\hline NY & 04120104 & Niagara & 0.45 & 8.16 & NULL & 0.13 & 0.03 & 0.57 & 0.00 & 0.46 & 0.48 & 0.82 & 1.47 & 4.71 & 1.81 & 0.00 & NULL & 0.01 & 0.01 & 0.71 & 0.38 & NR & NR \\
\hline NY & 04130001 & $\begin{array}{l}\text { Oak Orchard- } \\
\text { Twelvemile }\end{array}$ & 0.27 & 6.17 & NULL & 0.17 & 0.03 & 0.69 & 0.00 & 0.74 & 0.59 & 1.30 & 2.14 & 7.31 & 2.86 & 0.00 & NULL & 0.00 & 0.00 & 0.40 & 0.22 & NR & NR \\
\hline $\mathrm{NY}$ & 04130002 & Upper Genesee & 0.86 & 0.61 & NULL & 0.16 & 0.02 & 0.65 & 0.00 & 0.12 & 0.30 & 0.31 & 0.81 & 2.40 & 0.94 & 0.00 & NULL & 0.24 & 0.05 & 1.00 & 0.54 & NR & NR \\
\hline
\end{tabular}




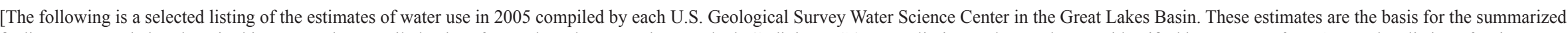
findings presented elsewhere in this report. The compiled values from selected New York watersheds (8-digit HUCs) are preliminary; these values are identified by bold typeface. A complete listing of estimates, including final, approved values from New York HUCs, is available for download from the U.S. Geological Survey National Water-Use Information Web site (http://water.usgs.gov/watuse/). Approximate areas

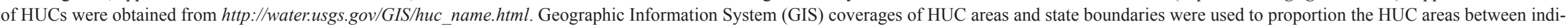
vidual Great Lakes States. Column tags are defined in appendix 1A. Data Dictionary; NA, not applicable; NR, not reported; NULL, value unknown, not reported]

\begin{tabular}{|c|c|c|c|c|c|c|c|c|c|c|c|c|c|c|c|c|c|c|c|c|c|c|c|}
\hline STATE & HUC8Code & HUC8Name & AREA & AREA $\%$ & $\begin{array}{l}\text { TP-Total- } \\
\text { Pop }\end{array}$ & $\begin{array}{l}\text { PS- } \\
\text { TOPop }\end{array}$ & $\begin{array}{c}\text { PS- } \\
\text { WGWFr }\end{array}$ & $\begin{array}{c}\text { PS- } \\
\text { WSWFr }\end{array}$ & $\begin{array}{l}\text { PS- } \\
\text { PrCap }\end{array}$ & $\begin{array}{l}\text { DO- } \\
\text { SSPop }\end{array}$ & $\begin{array}{c}\text { Do- } \\
\text { WGWFr }\end{array}$ & $\begin{array}{c}\text { Do- } \\
\text { WSWFr }\end{array}$ & $\begin{array}{c}\text { DO- } \\
\text { SSPCp }\end{array}$ & $\begin{array}{c}\text { DO- } \\
\text { PSDel }\end{array}$ & $\begin{array}{c}\text { PT- } \\
\text { WGWFr }\end{array}$ & $\begin{array}{c}\text { PT- } \\
\text { WSWFr }\end{array}$ & $\begin{array}{c}\text { PT- } \\
\text { Power }\end{array}$ & $\begin{array}{c}\text { PO- } \\
\text { WGWFr }\end{array}$ & $\begin{array}{c}\text { PO- } \\
\text { WSWFr }\end{array}$ & $\begin{array}{l}\text { P0- } \\
\text { Power }\end{array}$ & $\begin{array}{c}\text { PC- } \\
\text { WGWFr }\end{array}$ & $\begin{array}{c}\text { PC- } \\
\text { WSWFr }\end{array}$ & $\begin{array}{c}\text { PC- } \\
\text { Power }\end{array}$ \\
\hline NY & 04130003 & Lower Genese & 1,070 & 100 & 330.646 & 299.15 & 0.65 & 45.59 & 155 & 31.49 & 4.12 & 0.00 & 75 & 27.52 & 0.00 & 00 & 0.00 & 0.00 & 0.00 & 0.00 & .00 & .00 & 0.00 \\
\hline NY & 04140101 & $\begin{array}{l}\text { Irondequoit- } \\
\text { Ninemile }\end{array}$ & 708 & 14 & 3 & 351.27 & 3.81 & 0.00 & 11 & 46.48 & 3.48 & 0.00 & 75 & 10 & 0.00 & 0.00 & 00 & 0 & 00 & 00 & 00 & 00 & 00 \\
\hline NY & 04140102 & Salmon-Sandy & 969 & 100 & 54.107 & 53.56 & 1.98 & 9.20 & 355 & 0.55 & 0.04 & 0.00 & 75 & 5.34 & 0.00 & 0.00 & 0.00 & 0.00 & 0.00 & 0.00 & 0.00 & 0.00 & 0.00 \\
\hline NY & 04140201 & Seneca & 3,430 & 100 & 757.155 & 576.69 & 7.90 & 116.74 & 216 & 180.46 & 13.50 & 0.00 & 75 & 67.82 & 0.00 & 307.77 & $3,300.05$ & 0.00 & 307.77 & $3,300.05$ & 0.00 & 0.00 & 0.00 \\
\hline NY & 04140202 & Oneida & 1,470 & 100 & 236.306 & 169.98 & 2.78 & 12.00 & 87 & 66.32 & 4.97 & 0.00 & 75 & 17.70 & 0.00 & 0.00 & 0.00 & 0.00 & 0.00 & 0.00 & 0.00 & 0.00 & 0.00 \\
\hline NY & 04140203 & Oswego & 131 & 100 & 38.371 & 17.30 & 0.03 & 0.00 & 1 & 21.08 & 1.58 & 0.00 & 75 & 1.79 & 0.00 & 0.00 & 0.00 & 0.00 & 0.00 & 0.00 & 0.00 & 0.00 & 0.00 \\
\hline NY & 04150101 & Black & 1,920 & 100 & 70.270 & 39.52 & 1.73 & 8.30 & 254 & 30.74 & 2.31 & 0.00 & 75 & 3.85 & 0.00 & 0.00 & 0.00 & 0.00 & 0.00 & 0.00 & 0.00 & 0.00 & 0.00 \\
\hline NY & 04150102 & Chaumont-Perch & 380 & 100 & 22.767 & 13.60 & 0.08 & 0.00 & 6 & 9.17 & 0.68 & 0.00 & 75 & 1.35 & 0.00 & 0.00 & 0.00 & 0.00 & 0.00 & 0.00 & 0.00 & 0.00 & 0.00 \\
\hline NY & 04150301 & $\begin{array}{l}\text { Upper St. Law- } \\
\text { rence }\end{array}$ & 506 & 100 & 28003 & 223 & 000 & 0.17 & 11 & 25,77 & 1.94 & 0.00 & 75 & 0.22 & 0.00 & 0.00 & 0.00 & 0.00 & 0.00 & 0.00 & 0.00 & 0.00 & 0.00 \\
\hline NY & 04150302 & Oswegatchie & 1,040 & 100 & 27.604 & 8.61 & 0.27 & 0.36 & 43 & 18.99 & 1.42 & 0.00 & 75 & 0.86 & 0 . & 0.00 & 0.00 & 0.00 & 0.00 & 0.00 & 0.00 & 0.00 & 0.00 \\
\hline NY & 04150303 & Indian & 558 & 100 & 33.016 & 13.31 & 0.79 & 0.50 & 67 & 19.71 & 1.48 & 0.00 & 75 & 1.33 & 0.00 & 0.00 & 0.00 & 0.00 & 0.00 & 0.00 & 0.00 & 0.00 & 0.00 \\
\hline NY & 04150304 & Grass & 630 & 100 & 28.326 & 15.33 & 0.41 & 4.89 & 346 & 12.99 & 0.97 & 0.00 & 75 & 1.54 & 0.00 & 0.00 & 0.00 & 0.00 & 0.00 & 0.00 & 0.00 & 0.00 & 0.00 \\
\hline NY & 04150305 & Raquet & 1,250 & 100 & 35.055 & 21.84 & 0.84 & 2.35 & 166 & 13.22 & 0.99 & 0.00 & 75 & 2.19 & 0.00 & 0.00 & 0.00 & 0.00 & 0.00 & 0.00 & 0.00 & 0.00 & 0.00 \\
\hline NY & 04150306 & St. Regis & 853 & 100 & 16.025 & 2.38 & 0.27 & 0.00 & 31 & 13.65 & 1.03 & 0.00 & 75 & 0.24 & 0.00 & 0.00 & 0.00 & 0.00 & 0.00 & 0.00 & 0.00 & 0.00 & 0.00 \\
\hline NY & 04150307 & English-Salmon & 811 & 100 & 33.270 & 20.81 & 0.31 & 3.10 & 184 & 12.46 & 0.94 & 0.00 & 75 & 2.08 & 0.00 & 0.00 & 0.00 & 0.00 & 0.00 & 0.00 & 0.00 & 0.00 & 0.00 \\
\hline NY & 04120200 & Lake Erie & 573 & 22 & 0.000 & 0.00 & 0.01 & 164.81 & 0 & 0.00 & 0.00 & 0.00 & 0 & 0.00 & 0.00 & 426.77 & $3,345.52$ & 0.00 & 426.77 & $3,345.52$ & 0.00 & 0.00 & 0.00 \\
\hline NY & 04150200 & Lake Ontario & 3,430 & 100 & 0.000 & 0.00 & 0.00 & 70.06 & 0 & 0.00 & 0.00 & 0.00 & 0 & 0.00 & 0.00 & $2,033.13$ & $32,786.88$ & 0.00 & $2,033.13$ & $32,786.88$ & 0.00 & 0.00 & 0.00 \\
\hline $\mathrm{OH}$ & 04100001 & Ottawa-Stony & 14 & 21 & 235.769 & 222.7 & 0. & 0. & 0 & 13 & 1.05 & 0.02 & 81 & 21.94 & 0.00 & 0.00 & 0.00 & 0.00 & 0.00 & 0.00 & 0.00 & 0.00 & 0.00 \\
\hline $\mathrm{OH}$ & 04100002 & Raisin & 24 & 2 & 1.280 & 0.66 & 0.00 & 0.00 & 0 & 0.62 & 0.05 & 0.00 & 81 & 0.49 & 0.00 & 0.00 & 0.00 & 0.00 & 0.00 & 0.00 & 0.00 & 0.00 & 0.00 \\
\hline $\mathrm{OH}$ & 04100003 & St. Joseph & 218 & 20 & 14.373 & 8.13 & 1.13 & 0.00 & 139 & 6.24 & 0.46 & 0.01 & 75 & 1.62 & 0.00 & 0.00 & 0.00 & 0.00 & 0.00 & 0.00 & 0.00 & 0.00 & 0.00 \\
\hline $\mathrm{OH}$ & 04100004 & St. Marys & 436 & 53 & 35.065 & 20.51 & 2.30 & 0.00 & 112 & 14.56 & 1.07 & 0.02 & 75 & 1.53 & 0.00 & 5.64 & 43.31 & 0.00 & 5.64 & 43.31 & 0.00 & 0.00 & 0.00 \\
\hline $\mathrm{OH}$ & 04100005 & Upper Maumee & 184 & 48 & 10.936 & 7.71 & 0.74 & 4.09 & 627 & 3.23 & 0.51 & 0.01 & 161 & 0.42 & 0.00 & 0.00 & 0.00 & 0.00 & 0.00 & 0.00 & 0.00 & 0.00 & 0.00 \\
\hline $\mathrm{OH}$ & 04100006 & Tiffin & 556 & 71 & 43.307 & 24.27 & 2.23 & 2.03 & 176 & 19.04 & 1.40 & 0.03 & 75 & 1.40 & 0.00 & 0.00 & 0.00 & 0.00 & 0.00 & 0.00 & 0.00 & 0.00 & 0.00 \\
\hline $\mathrm{OH}$ & 04100007 & Auglaize & 1,556 & 94 & 195.092 & 138.92 & 4.86 & 21.88 & 192 & 56.17 & 4.13 & 0.08 & 75 & 9.57 & 0.00 & 0.00 & 0.00 & 0.00 & 0.00 & 0.00 & 0.00 & 0.00 & 0.00 \\
\hline $\mathrm{OH}$ & 04100008 & Blanchard & 757 & 100 & 92.257 & 54.40 & 1.19 & 7.76 & 165 & 37.85 & 2.78 & 0.06 & 75 & 4.57 & 0.00 & 0.00 & 0.00 & 0.00 & 0.00 & 0.00 & 0.00 & 0.00 & 0.00 \\
\hline $\mathrm{OH}$ & 04100009 & Lower Maumee & 1,080 & 100 & 298.637 & 240.83 & 1.02 & 9.71 & 45 & 57.80 & 4.25 & 0.09 & 75 & 20.41 & 0.00 & 730.69 & $4,165.48$ & 0.00 & 730.69 & 165.48 & 0.00 & 0.00 & 0.00 \\
\hline $\mathrm{OH}$ & 04100010 & Cedar-Portage & 958 & 100 & 169.879 & 117.26 & 1.08 & 5.37 & 55 & 52.62 & 3.87 & 0.08 & 75 & 5.11 & 0.00 & 0.00 & 0.00 & 0.00 & 0.00 & 0.00 & 0.00 & 0.00 & 0.00 \\
\hline $\mathrm{OH}$ & 04100011 & Sandusky & 1,850 & 100 & 217.856 & 153.35 & 1.43 & 9.99 & 74 & 64.51 & 4.74 & 0.10 & 75 & 7.77 & 0.00 & 0.00 & 0.00 & 0.00 & 0.00 & 0.00 & 0.00 & 0.00 & 0.00 \\
\hline $\mathrm{OH}$ & 04100012 & Huron-Vermilion & 754 & 100 & 92.201 & 88.10 & 0.39 & 3.87 & 48 & 4.10 & 0.30 & 0.01 & 76 & 5.57 & 0.00 & 0.00 & 0.00 & 0.00 & 0.00 & 0.00 & 0.00 & 0.00 & 0.00 \\
\hline $\mathrm{OH}$ & 04110001 & Black-Rocky & 888 & 100 & 729.358 & 662.73 & 0.39 & 3.77 & 6 & 66.63 & 4.90 & 0.10 & 75 & 41.95 & 0.00 & 0.00 & 0.00 & 0.00 & 0.00 & 0.00 & 0.00 & 0.00 & 0.00 \\
\hline
\end{tabular}


Appendix 1B. Estimates of Withdrawals and Other Elements of Water Use by State.-Continued

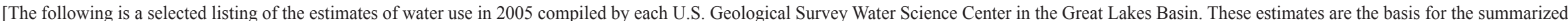
findings presented elsewhere in this report. The compiled values from selected New York watersheds (8-digit HUCs) are preliminary; these values are identified by bold typeface. A complete listing of estimates,

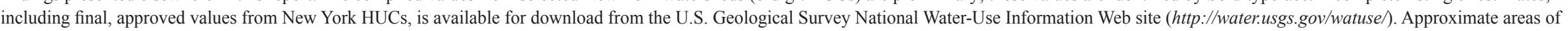

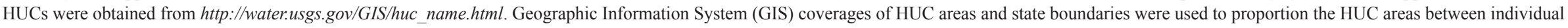
Great Lakes States. Column tags are defined in appendix 1A. Data Dictionary; NA, not applicable; NR, not reported; NULL, value unknown, not reported]

\begin{tabular}{|c|c|c|c|c|c|c|c|c|c|c|c|c|c|c|c|c|c|c|c|c|c|c|c|}
\hline STATE & HUC8Code & HUC8Name & $\begin{array}{c}\text { IN- } \\
\text { WGWFr }\end{array}$ & $\begin{array}{c}\text { IN- } \\
\text { WSWFr }\end{array}$ & $\begin{array}{c}\text { IN- } \\
\text { RecWW }\end{array}$ & $\begin{array}{c}\text { MI- } \\
\text { WGWFr }\end{array}$ & $\begin{array}{c}\text { MI- } \\
\text { WGWSa }\end{array}$ & $\begin{array}{c}\text { MI- } \\
\text { WSWFr }\end{array}$ & $\begin{array}{c}\text { MI- } \\
\text { WSWSa }\end{array}$ & $\begin{array}{c}\text { IG- } \\
\text { WGWFr }\end{array}$ & $\begin{array}{c}\text { IG- } \\
\text { WSWFr }\end{array}$ & $\begin{array}{c}\text { IT- } \\
\text { WGWFr }\end{array}$ & $\begin{array}{c}\text { IT- } \\
\text { WSWFr }\end{array}$ & $\begin{array}{l}\text { IT- } \\
\text { IrSpr }\end{array}$ & $\begin{array}{l}\text { IT- } \\
\text { IrMic }\end{array}$ & $\begin{array}{l}\text { IT- } \\
\text { IrSur }\end{array}$ & $\begin{array}{c}\text { IT- } \\
\text { RecWW }\end{array}$ & $\begin{array}{c}\text { LA- } \\
\text { WGWFr }\end{array}$ & $\begin{array}{c}\text { LA- } \\
\text { WSWFr }\end{array}$ & $\begin{array}{c}\text { LS- } \\
\text { WGWFr }\end{array}$ & $\begin{array}{c}\text { LS- } \\
\text { WSWFr }\end{array}$ & $\begin{array}{c}\text { CO- } \\
\text { WGWFr }\end{array}$ & $\begin{array}{c}\text { Co- } \\
\text { WSWFr }\end{array}$ \\
\hline NY & 04130003 & Lower Genesee & 0.83 & 6.51 & NULL & 0.18 & 0.01 & 0.76 & 0.00 & 0.34 & 0.91 & 0.72 & 1.96 & 5.25 & 1.94 & 0.00 & NULL & 0.01 & 0.07 & 0.97 & 0.52 & NR & NR \\
\hline NY & 04140101 & $\begin{array}{l}\text { Irondequoit- } \\
\text { Ninemile }\end{array}$ & 0.77 & 8.28 & NULL & 0.08 & 0.01 & 0.31 & 0.00 & 0.20 & 0.57 & 0.32 & 0.89 & 1.94 & 0.58 & 0.00 & NULL & 0.07 & 0.27 & 0.28 & 0.15 & NR & NR \\
\hline NY & 04140102 & Salmon-Sandy & 0.37 & 0.70 & NULL & 0.07 & 0.00 & 0.27 & 0.00 & 0.11 & 0.27 & 0.15 & 0.38 & 0.79 & 0.21 & 0.00 & NULL & 0.00 & 1.66 & 0.39 & 0.21 & NR & NR \\
\hline NY & 04140201 & Seneca & 2.88 & 22.79 & NULL & 0.69 & 0.04 & 2.91 & 0.00 & 0.71 & 1.75 & 0.99 & 2.48 & 5.12 & 1.36 & 0.00 & NULL & 0.29 & 0.74 & 2.38 & 1.30 & NR & NR \\
\hline NY & 04140202 & Oneida & 1.15 & 6.00 & NULL & 0.13 & 0.02 & 0.52 & 0.00 & 0.38 & 0.95 & 0.45 & 1.14 & 1.91 & 0.34 & 0.00 & NULL & 1.24 & 2.61 & 0.81 & 0.44 & NR & NR \\
\hline NY & 04140203 & Oswego & 0.26 & 0.64 & NULL & 0.01 & 0.00 & 0.06 & 0.00 & 0.03 & 0.08 & 0.04 & 0.11 & 0.22 & 0.06 & 0.00 & NULL & 0.00 & 0.30 & 0.04 & 0.02 & NR & NR \\
\hline NY & 04150101 & Black & 0.50 & 1.11 & NULL & 0.08 & 0.01 & 0.32 & 0.00 & 0.11 & 0.30 & 0.13 & 0.35 & 0.55 & 0.08 & 0.00 & NULL & 1.24 & 1.94 & 0.79 & 0.43 & NR & NR \\
\hline NY & 04150102 & Chaumont-Perch & 0.09 & 0.35 & NULL & 0.03 & 0.00 & 0.12 & 0.00 & 0.05 & 0.10 & 0.05 & 0.11 & 0.16 & 0.01 & 0.00 & NULL & 0.00 & 0.00 & 0.25 & 0.14 & NR & NR \\
\hline NY & 04150301 & $\begin{array}{l}\text { Upper St. Law- } \\
\text { rence }\end{array}$ & 0.12 & 0.43 & NULL & 0.02 & 0.00 & 0.07 & 0.00 & 0.04 & 0.06 & 0.04 & 0.07 & 0.12 & 0.01 & 0.00 & NULL & 0.00 & 0.02 & 0.18 & 0.10 & NR & NR \\
\hline NY & 04150302 & Oswegatchie & 0.13 & 0.42 & NULL & 0.04 & 0.00 & 0.17 & 0.00 & 0.07 & 0.09 & 0.08 & 0.11 & 0.22 & 0.04 & 0.00 & NULL & 0.13 & 0.27 & 0.41 & 0.22 & NR & NR \\
\hline $\mathrm{NY}$ & 04150303 & Indian & 0.14 & 0.50 & NULL & 0.03 & 0.00 & 0.13 & 0.00 & 0.06 & 0.11 & 0.06 & 0.12 & 0.19 & 0.02 & 0.00 & NULL & 0.00 & 0.23 & 0.32 & 0.17 & NR & NR \\
\hline $\mathrm{NY}$ & 04150304 & Grass & 0.13 & 0.43 & NULL & 0.02 & 0.00 & 0.10 & 0.00 & 0.04 & 0.04 & 0.04 & 0.05 & 0.13 & 0.02 & 0.00 & NULL & 0.00 & 0.05 & 0.24 & 0.13 & NR & NR \\
\hline NY & 04150305 & Raquette & 0.15 & 0.46 & NULL & 0.03 & 0.00 & 0.11 & 0.00 & 0.07 & 0.09 & 0.08 & 0.11 & 0.22 & 0.04 & 0.00 & NULL & 0.09 & 1.30 & 0.27 & 0.15 & NR & NR \\
\hline NY & 04150306 & St. Regis & 0.06 & 0.18 & NULL & 0.02 & 0.00 & 0.07 & 0.00 & 0.04 & 0.07 & 0.05 & 0.10 & 0.24 & 0.06 & 0.00 & NULL & 0.19 & 2.73 & 0.26 & 0.14 & NR & NR \\
\hline NY & 04150307 & English-Salmon & 0.11 & 0.27 & NULL & 0.02 & 0.00 & 0.06 & 0.00 & 0.03 & 0.09 & 0.04 & 0.13 & 0.28 & 0.08 & 0.00 & NULL & 0.26 & 3.64 & 0.25 & 0.13 & NR & NR \\
\hline NY & 04120200 & Lake Erie & 0.00 & 10.46 & NULL & 0.00 & 0.00 & 0.00 & 0.00 & 0.01 & 0.02 & 0.01 & 0.03 & 0.04 & 0.01 & 0.00 & NULL & 0.00 & 0.00 & 0.00 & 0.00 & NR & NR \\
\hline NY & 04150200 & Lake Ontario & 0.00 & 0.22 & NULL & 0.00 & 0.00 & 0.00 & 0.00 & 0.01 & 0.02 & 0.01 & 0.03 & 0.06 & 0.02 & 0.00 & NULL & 0.00 & 0.00 & 0.00 & 0.00 & NR & NR \\
\hline $\mathrm{OH}$ & 04100001 & Ottawa-Stony & 0.03 & 0.00 & 0.00 & 2.67 & 0.00 & 0.00 & 0.00 & 0.28 & 0.17 & 0.47 & 0.17 & 1.60 & 0.00 & 0.00 & 0.00 & 0.00 & 0.00 & 0.01 & 0.04 & 0.00 & 0.00 \\
\hline $\mathrm{OH}$ & 04100002 & Raisin & 0.00 & 0.00 & 0.00 & 0.00 & 0.00 & 0.00 & 0.00 & 0.00 & 0.00 & 0.00 & 0.00 & 0.08 & 0.00 & 0.00 & 0.00 & 0.00 & 0.00 & 0.00 & 0.02 & 0.00 & 0.00 \\
\hline $\mathrm{OH}$ & 04100003 & St. Joseph & 0.14 & 0.00 & 0.00 & 0.00 & 0.00 & 0.00 & 0.00 & 0.00 & 0.00 & 0.14 & 0.00 & 0.25 & 0.00 & 0.00 & 0.00 & 0.00 & 0.00 & 0.02 & 0.09 & 0.00 & 0.00 \\
\hline $\mathrm{OH}$ & 04100004 & St. Marys & 0.00 & 0.00 & 0.00 & 1.63 & 0.00 & 0.00 & 0.00 & 0.15 & 0.05 & 0.15 & 0.05 & 0.35 & 0.00 & 0.00 & 0.00 & 0.38 & 0.23 & 0.47 & 0.60 & 0.41 & 0.00 \\
\hline $\mathrm{OH}$ & 04100005 & Upper Maumee & 0.00 & 0.00 & 0.00 & 0.00 & 0.00 & 0.00 & 0.00 & 0.00 & 0.00 & 0.00 & 0.00 & 0.14 & 0.00 & 0.00 & 0.00 & 0.00 & 0.00 & 0.01 & 0.06 & 0.00 & 0.00 \\
\hline $\mathrm{OH}$ & 04100006 & Tiffin & 0.10 & 0.00 & 0.00 & 0.00 & 0.00 & 0.00 & 0.00 & 0.02 & 0.00 & 0.02 & 0.00 & 1.21 & 0.00 & 0.00 & 0.00 & 0.00 & 0.00 & 0.05 & 0.26 & 0.04 & 0.00 \\
\hline $\mathrm{OH}$ & 04100007 & Auglaize & 1.14 & 0.20 & 0.00 & 5.45 & 0.00 & 0.27 & 0.00 & 0.28 & 0.25 & 0.28 & 0.25 & 1.93 & 0.00 & 0.00 & 0.00 & 0.00 & 0.00 & 0.22 & 0.67 & 0.00 & 0.00 \\
\hline $\mathrm{OH}$ & 04100008 & Blanchard & 5.30 & 26.62 & 0.00 & 2.62 & 0.00 & 0.06 & 0.00 & 0.12 & 0.28 & 0.13 & 0.34 & 0.86 & 0.00 & 0.00 & 0.00 & 0.00 & 0.00 & 0.06 & 0.31 & 0.00 & 0.00 \\
\hline $\mathrm{OH}$ & 04100009 & Lower Maumee & 0.01 & 6.70 & 0.00 & 2.19 & 0.00 & 0.00 & 0.00 & 0.39 & 0.37 & 0.55 & 0.42 & 3.80 & 0.00 & 0.00 & 0.00 & 0.00 & 0.00 & 0.07 & 0.29 & 0.05 & 2.50 \\
\hline $\mathrm{OH}$ & 04100010 & Cedar-Portage & 5.82 & 47.51 & 0.00 & 1.43 & 0.00 & 0.00 & 0.00 & 0.12 & 0.07 & 0.49 & 0.16 & 1.68 & 0.00 & 0.00 & 0.00 & 0.00 & 0.00 & 0.04 & 0.13 & 0.01 & 0.81 \\
\hline $\mathrm{OH}$ & 04100011 & Sandusky & 0.43 & 8.95 & 0.00 & 7.99 & 0.00 & 0.18 & 0.00 & 0.18 & 0.19 & 0.20 & 0.22 & 2.27 & 0.00 & 0.00 & 0.00 & 0.00 & 3.43 & 0.14 & 0.70 & 0.39 & 2.65 \\
\hline $\mathrm{OH}$ & 04100012 & Huron-Vermilion & 0.08 & 0.00 & 0.00 & 0.00 & 0.00 & 0.00 & 0.00 & 0.05 & 2.34 & 0.39 & 2.90 & 3.83 & 0.00 & 0.00 & 0.00 & 0.00 & 0.00 & 0.10 & 0.24 & 0.00 & 0.00 \\
\hline $\mathrm{OH}$ & 04110001 & Black-Rocky & 0.08 & 100.95 & 0.00 & 0.00 & 0.00 & 0.00 & 0.00 & 0.12 & 1.51 & 0.12 & 3.14 & 4.60 & 0.00 & 0.00 & 0.00 & 0.00 & 0.00 & 0.15 & 0.26 & 0.00 & 0.00 \\
\hline
\end{tabular}




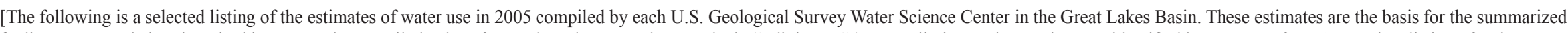
findings presented elsewhere in this report. The compiled values from selected New York watersheds (8-digit HUCs) are preliminary; these values are identified by bold typeface. A complete listing of estimates, including final, approved values from New York HUCs, is available for download from the U.S. Geological Survey National Water-Use Information Web site (http://water.usgs.gov/watuse/). Approximate areas

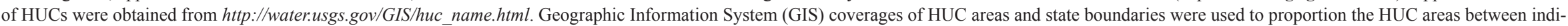
vidual Great Lakes States. Column tags are defined in appendix 1A. Data Dictionary; NA, not applicable; NR, not reported; NULL, value unknown, not reported]

\begin{tabular}{|c|c|c|c|c|c|c|c|c|c|c|c|c|c|c|c|c|c|c|c|c|c|c|c|}
\hline STATE & HUC8Code & HUC8Name & AREA & AREA $\%$ & $\begin{array}{l}\text { TP-Total- } \\
\text { Pop }\end{array}$ & $\begin{array}{l}\text { PS- } \\
\text { TOPop }\end{array}$ & $\begin{array}{c}\text { PS- } \\
\text { WGWFr }\end{array}$ & $\begin{array}{c}\text { PS- } \\
\text { WSWFr }\end{array}$ & $\begin{array}{c}\text { PS- } \\
\text { PrCap }\end{array}$ & $\begin{array}{l}\text { DO- } \\
\text { SSPop }\end{array}$ & $\begin{array}{c}\text { Do- } \\
\text { WGWFr }\end{array}$ & $\begin{array}{c}\text { Do- } \\
\text { WSWFr }\end{array}$ & $\begin{array}{c}\text { DO- } \\
\text { SSPCp }\end{array}$ & $\begin{array}{c}\text { DO- } \\
\text { PSDel }\end{array}$ & $\begin{array}{c}\text { PT- } \\
\text { WGWFr }\end{array}$ & $\begin{array}{c}\text { PT- } \\
\text { r WSWFr }\end{array}$ & $\begin{array}{c}\text { PT- } \\
\text { Power }\end{array}$ & $\begin{array}{c}\text { PO- } \\
\text { WGWFr }\end{array}$ & $\begin{array}{c}\text { PO- } \\
\text { WSWFr }\end{array}$ & $\begin{array}{l}\text { P0- } \\
\text { Power }\end{array}$ & $\begin{array}{c}\text { PC- } \\
\text { WGWFr }\end{array}$ & $\begin{array}{c}\text { PC- } \\
\text { WSWFr }\end{array}$ & $\begin{array}{c}\text { PC- } \\
\text { Power }\end{array}$ \\
\hline $\mathrm{OH}$ & 04110002 & Cuyahoga & 804 & 100 & $1,040.667$ & 910.75 & 15.59 & 37.22 & 58 & 129.91 & 9.55 & 0.19 & 75 & 58.62 & 0.00 & 0.00 & 125.72 & 0.00 & 0.00 & 125.72 & 0.00 & 0.00 & 0.00 \\
\hline $\mathrm{OH}$ & 04110003 & $\begin{array}{l}\text { Ashtabula- } \\
\text { Chagrin }\end{array}$ & 62 & 95 & 699.297 & 629.38 & 7 & 0.00 & 2 & 02 & 4 & 10 & 75 & 5.91 & 0 & 00 & 0.00 & 0.00 & 0.00 & .00 & 0.00 & .00 & 0.00 \\
\hline $\mathrm{OH}$ & 04110004 & Grand & 710 & 100 & 120.473 & 88.30 & 0.24 & 0.05 & 3 & 32.17 & 2.36 & 0.05 & 75 & 7.16 & 0.00 & 0.00 & 0.00 & 0.00 & 0.00 & 0.00 & 0.00 & 0.00 & 0.00 \\
\hline $\mathrm{OH}$ & 04120101 & $\begin{array}{l}\text { Chautauqua- } \\
\text { Conneaut }\end{array}$ & 54 & 6 & 17.176 & 12.37 & 0.00 & 0.00 & 0 & 4.80 & 0.35 & 0.01 & 75 & 5.18 & 0.00 & 0.00 & 0.00 & 0.00 & 0.00 & 0.00 & 0.00 & 0.00 & 0.00 \\
\hline $\mathrm{OH}$ & 04120200 & Lake Erie & 3,401 & 71 & 0.751 & 0.57 & .00 & 427.64 & NA & 0.18 & 0.01 & 0 & 55 & 0.01 & 0.00 & $1,781.66$ & $22,043.53$ & 0.00 & $1,635.79$ & $14,663.40$ & 0.00 & 145.87 & $7,380.13$ \\
\hline PA & 04110003 & $\begin{array}{l}\text { Ashtabula- } \\
\text { Chagrin }\end{array}$ & 7 & 1 & 440 & 0.00 & 0 & 0.00 & 0 & 0.44 & 0.03 & 0.00 & 68 & 0.00 & 0 & 0 & 0.00 & 0 & 0.00 & 0.00 & 0.00 & 0.00 & 0.00 \\
\hline $\mathrm{PA}$ & 04120101 & $\begin{array}{r}\text { Chautauqua- } \\
\text { Conneaut }\end{array}$ & 509 & 58 & 260.407 & 223.39 & 13 & 0 & 10 & 37.02 & 2 & 0. & 60 & 13.55 & 0. & 0.00 & 28.19 & 0.00 & 0.00 & 0.00 & 0.00 & 0.00 & 28.19 \\
\hline PA & 04130002 & Upper Genesee & 91 & 6 & 2.975 & 1.08 & 2 & 00 & 111 & 1.89 & 0.11 & 0.00 & 58 & 0.07 & 0.00 & 0.00 & 0.00 & 0.00 & 0.00 & 0.00 & 0.00 & 0.00 & 0.00 \\
\hline PA & 04120200 & Lake Erie & 718 & 15 & 0.000 & 0.00 & 0.00 & 31.16 & 0 & 0.00 & 0.00 & 0.00 & 0 & 0.00 & 0.00 & 0.00 & 0.00 & 0.00 & 0.00 & 0.00 & 0.00 & 0.00 & 0.00 \\
\hline WI & 04010201 & St. Louis & 71 & 2 & 19.980 & 14.38 & 0.01 & 0.00 & 1 & 5.60 & 0.04 & 0.00 & 7 & 1.39 & 0.00 & 0.00 & 0.00 & 0.00 & 0.00 & 0.00 & 0.00 & 0.00 & 0.00 \\
\hline WI & 04010301 & Beartrap-Nemadji & 1,587 & 86 & 40.521 & 26.16 & 0.37 & 0.00 & 14 & 14.36 & 0.69 & 0.00 & 48 & 1.81 & 0.00 & 0.00 & 0.00 & 0.00 & 0.00 & 0.00 & 0.00 & 0.00 & 0.00 \\
\hline WI & 04010302 & Bad-Montreal & 1,224 & 92 & 11.425 & 3.92 & 0.27 & 0.00 & 69 & 7.51 & 0.28 & 0.00 & 37 & 0.18 & 0.00 & 0.00 & 0.00 & 0.00 & 0.00 & 0.00 & 0.00 & 0.00 & 0.00 \\
\hline WI & 04020101 & $\begin{array}{l}\text { Black- } \\
\text { Presque Isle }\end{array}$ & 71 & 100 & م 000 & 0.00 & 000 & 0.00 & 0 & 0.00 & 0,00 & 0.00 & 0 & 0.00 & 0.00 & 0.00 & 0.00 & 0.00 & 0.00 & 0.00 & 0.00 & 0.00 & 0.00 \\
\hline WI & 04020102 & Ontonagon & 41 & 3 & 0.000 & 0.00 & 0.00 & 0.00 & 0 & 0.00 & 0.00 & 0.00 & 0 & 0.00 & 0.00 & 0.44 & 2.96 & 0.00 & 0.44 & 2.96 & 0.00 & 0.00 & 0.00 \\
\hline WI & 04030101 & $\begin{array}{l}\text { Manitowoc- } \\
\text { Sheboygan }\end{array}$ & 1,650 & 100 & 243.540 & 164.27 & 7.35 & 0.00 & 45 & 79.27 & 3.99 & 0.00 & 50 & 9.95 & 1.02 & 0.00 & 102.05 & 0.00 & 0.00 & 0.00 & 1.02 & 0.00 & 102.05 \\
\hline WI & 04030102 & Door-Kewaunee & 776 & 100 & 56.888 & 19.11 & 2.59 & 0.00 & 136 & 37.78 & 1.37 & 0.00 & 36 & 1.06 & 0.01 & .00 & 1.13 & 0.00 & 0.00 & 0.00 & 0.01 & 0.00 & 1.13 \\
\hline WI & 04030103 & Duck-Pensaukee & 483 & 100 & 15.890 & 5.83 & 0.51 & 0.00 & 88 & 10.06 & 0.45 & 0.00 & 45 & 0.17 & 0.00 & 0.00 & 0.00 & 0.00 & 0.00 & 0.00 & 0.00 & 0.00 & 0.00 \\
\hline WI & 04030104 & Oconto & 1,040 & 100 & 31.386 & 11.04 & 1.50 & 0.00 & 136 & 20.35 & 1.03 & 0.00 & 51 & 0.50 & 0.00 & 0.00 & 0.00 & 0.00 & 0.00 & 0.00 & 0.00 & 0.00 & 0.00 \\
\hline WI & 04030105 & Peshtigo & 1,170 & 100 & 35.373 & 18.12 & 0.86 & 0.00 & 47 & 17.25 & 0.85 & 0.00 & 49 & 0.97 & 0.00 & 1.31 & 8.76 & 0.00 & 1.31 & 8.76 & 0.00 & 0.00 & 0.00 \\
\hline WI & 04030106 & Brule & 188 & 18 & 2.042 & 1.81 & 0.08 & 0.00 & 44 & 0.23 & 0.04 & 0.00 & 172 & 0.03 & 0.00 & 0.00 & 0.00 & 0.00 & 0.00 & 0.00 & 0.00 & 0.00 & 0.00 \\
\hline WI & 04030108 & Menominee & 1,323 & 57 & 17.310 & 3.27 & 0.39 & 0.00 & 119 & 14.04 & 0.67 & 0.00 & 48 & 0.10 & 0.00 & 24.87 & 234.61 & 0.00 & 24.87 & 234.61 & 0.00 & 0.00 & 0.00 \\
\hline WI & 04030201 & Upper Fox & 1,610 & 100 & 136.991 & 101.53 & 4.42 & 0.00 & 44 & 35.46 & 2.98 & 0.00 & 84 & 5.52 & 0.00 & 0.00 & 0.00 & 0.00 & 0.00 & 0.00 & 0.00 & 0.00 & 0.00 \\
\hline WI & 04030202 & Wolf & 3,720 & 100 & 162.604 & 67.51 & 10.95 & 0.00 & 162 & 95.09 & 5.26 & 0.00 & 5 & 15 & 0.00 & .00 & 0.00 & 0.00 & 0.00 & .00 & 0.00 & 0.00 & 0.00 \\
\hline WI & 04030203 & Lake Winnebago & 570 & 100 & 82.220 & 54.64 & 6.00 & 21.15 & 497 & 27.58 & 1.52 & 0.00 & 55 & 2.58 & 0.00 & 8.29 & 55.24 & 0.00 & 8.29 & 55.24 & 0.00 & 0.00 & 0.00 \\
\hline WI & 04030204 & Lower Fox & 438 & 100 & 420.220 & 397.74 & 19.68 & 2.77 & 56 & 22.49 & 1.57 & 0.00 & 70 & 20.95 & 0.00 & 448.42 & $3,123.92$ & 0.00 & 448.42 & $3,123.92$ & 0.00 & 0.00 & 0.00 \\
\hline WI & 04040002 & Pike-Root & 337 & 84 & 436.729 & 346.04 & 0.60 & 0.00 & 2 & 90.69 & 2.71 & 0.00 & 30 & 19.28 & 0.00 & 0.00 & 0.00 & 0.00 & 0.00 & 0.00 & 0.00 & 0.00 & 0.00 \\
\hline WI & 04040003 & Milwaukee & 861 & 100 & 993.940 & 931.68 & 13.86 & 0.00 & 15 & 62.27 & 5.02 & 0.00 & 81 & 63.60 & 0.00 & 167.42 & $1,554.58$ & 0.00 & 167.42 & $1,554.58$ & 0.00 & 0.00 & 0.00 \\
\hline WI & 04020300 & Lake Superior & 2,057 & 10 & 0.000 & 0.00 & 0.00 & 4.01 & 0 & 0.00 & 0.00 & 0.00 & 0 & 0.00 & 0.00 & 50.56 & 337.08 & 0.00 & 50.56 & 337.08 & 0.00 & 0.00 & 0.00 \\
\hline WI & 04060200 & Lake Michigan & 7,330 & 33 & 0.000 & 0.00 & 0.00 & 219.01 & 0 & 0.00 & 0.00 & 0.00 & 0 & 0.00 & 0.00 & $4,531.15$ & $30,147.38$ & 0.00 & $4,531.15$ & $30,147.38$ & 0.00 & 0.00 & 0.00 \\
\hline
\end{tabular}




\section{Appendix 1B. Estimates of Withdrawals and Other Elements of Water Use by State.-Continued}

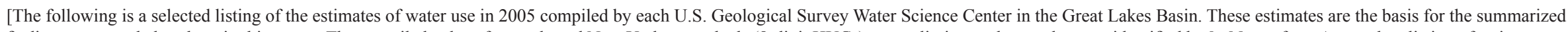

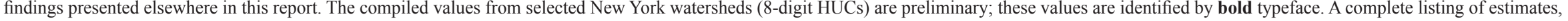

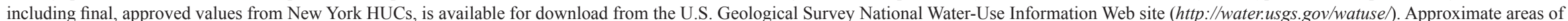

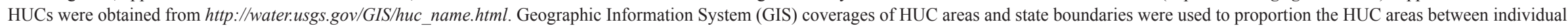
Great Lakes States. Column tags are defined in appendix $1 A$. Data Dictionary; NA, not applicable; NR, not reported; NULL, value unknown, not reported]

\begin{tabular}{|c|c|c|c|c|c|c|c|c|c|c|c|c|c|c|c|c|c|c|c|c|c|c|c|}
\hline STATE & HUC8Code & HUC8Name & $\begin{array}{c}\text { IN- } \\
\text { WGWFr }\end{array}$ & $\begin{array}{c}\text { IN- } \\
\text { WSWFr }\end{array}$ & $\begin{array}{c}\text { IN- } \\
\text { RecWW }\end{array}$ & $\begin{array}{c}\text { MI- } \\
\text { WGWFr }\end{array}$ & $\begin{array}{c}\text { MI- } \\
\text { WGWSa }\end{array}$ & $\begin{array}{c}\text { MI- } \\
\text { WSWFr }\end{array}$ & $\begin{array}{c}\text { Ml- } \\
\text { WSWSa }\end{array}$ & $\begin{array}{c}\text { IG- } \\
\text { WGWFr }\end{array}$ & $\begin{array}{c}\text { IG- } \\
\text { WSWFr }\end{array}$ & $\begin{array}{c}\text { IT- } \\
\text { WGWFr }\end{array}$ & $\begin{array}{c}\text { IT- } \\
\text { WSWFr }\end{array}$ & $\begin{array}{l}\text { IT- } \\
\text { IrSpr }\end{array}$ & $\begin{array}{l}\text { IT- } \\
\text { IrMic }\end{array}$ & $\begin{array}{l}\text { IT- } \\
\text { IrSur }\end{array}$ & $\begin{array}{c}\text { IT- } \\
\text { RecWW }\end{array}$ & $\begin{array}{l}\text { LA- } \\
\text { WGWFr }\end{array}$ & $\begin{array}{l}\text { LA- } \\
\text { WSWFr }\end{array}$ & $\begin{array}{c}\text { LS- } \\
\text { WGWFr }\end{array}$ & $\begin{array}{c}\text { LS- } \\
\text { WSWFr }\end{array}$ & $\begin{array}{c}\text { CO- } \\
\text { WGWFr }\end{array}$ & $\begin{array}{c}\text { Co- } \\
\text { WSWFr }\end{array}$ \\
\hline $\mathrm{OH}$ & 04110002 & Cuyahoga & 1.70 & 120.38 & 0.00 & 0.20 & 0.00 & 0.54 & 0.00 & 0.42 & 0.82 & 0.72 & 0.85 & 2.74 & 0.00 & 0.00 & 0.00 & 0.00 & 0.00 & 0.08 & 0.09 & 0.08 & 1.76 \\
\hline $\mathrm{OH}$ & 04110003 & $\begin{array}{l}\text { Ashtabula- } \\
\text { Chagrin }\end{array}$ & 0.00 & 0.00 & 0.00 & 0.00 & 0.00 & 0.00 & 0.00 & 0.01 & 1.00 & 0.30 & 4.41 & 3.68 & 0.00 & 0.00 & 0.00 & 0.00 & 0.00 & 0.09 & 0.10 & 0.00 & 0.01 \\
\hline $\mathrm{OH}$ & 04110004 & Grand & 0.00 & 0.40 & 0.00 & 0.00 & 0.00 & 0.00 & 0.00 & 0.09 & 0.20 & 0.10 & 0.54 & 1.25 & 0.00 & 0.00 & 0.00 & 0.00 & 0.00 & 0.13 & 0.19 & 0.00 & 0.00 \\
\hline $\mathrm{OH}$ & 04120101 & $\begin{array}{l}\text { Chautauqua- } \\
\text { Conneaut }\end{array}$ & 0.00 & 9.00 & 0.00 & 0.00 & 0.00 & 0.05 & 0.00 & 0.00 & 0.02 & 0.00 & 0.02 & 0.12 & 0.00 & 0.00 & 0.00 & 0.00 & 0.00 & 0.01 & 0.02 & 0.00 & 0.00 \\
\hline $\mathrm{OH}$ & 04120200 & Lake Erie & 0.00 & 0.00 & 0.00 & 7.24 & 0.00 & 4.41 & 0.00 & 0.00 & 0.08 & 0.00 & 0.18 & 0.01 & 0.00 & 0.00 & 0.00 & 0.00 & 0.00 & 0.00 & 0.00 & 0.00 & 0.00 \\
\hline PA & 04110003 & $\begin{array}{l}\text { Ashtabula- } \\
\text { Chagrin }\end{array}$ & 0.00 & 0.00 & NULL & 0.00 & 0.00 & 0.01 & 0.00 & NR & NR & 0.00 & 0.00 & 0.00 & 0.00 & 0.00 & NULL & 0.03 & 0.03 & 0.00 & 0.00 & NR & NR \\
\hline PA & 04120101 & $\begin{array}{r}\text { Chautauqua- } \\
\text { Conneaut }\end{array}$ & 0.02 & 0.01 & NULL & 0.10 & 0.00 & 0.44 & 0.00 & NR & NR & 0.14 & 0.45 & 0.99 & 0.00 & 0.00 & NULL & 2.31 & 1.90 & 0.40 & 0.06 & NR & NR \\
\hline PA & 04130002 & Upper Genesee & 0.00 & 0.00 & NULL & 0.01 & 0.00 & 0.00 & 0.00 & NR & NR & 0.00 & 0.00 & 0.00 & 0.00 & 0.00 & NULL & 0.00 & 1.52 & 0.03 & 0.00 & NR & NR \\
\hline PA & 04120200 & Lake Erie & 0.00 & 5.20 & NULL & 0.00 & 0.00 & 0.00 & 0.00 & NR & NR & 0.00 & 0.00 & 0.00 & 0.00 & 0.00 & NULL & 0.00 & 0.00 & 0.00 & 0.00 & NR & NR \\
\hline WI & 04010201 & St. Louis & 0.00 & 0.06 & NULL & 0.01 & 0.00 & 0.01 & 0.00 & NR & NR & 0.02 & 0.00 & 0.02 & 0.00 & 0.00 & NULL & 0.00 & 0.00 & 0.01 & 0.00 & 0.00 & 0.00 \\
\hline WI & 04010301 & Beartrap-Nemadji & 0.02 & 0.96 & NULL & 0.54 & 0.00 & 0.07 & 0.00 & NR & NR & 0.30 & 0.02 & 0.21 & 0.00 & 0.00 & NULL & 3.91 & 0.00 & 0.18 & 0.02 & 0.08 & 0.00 \\
\hline WI & 04010302 & Bad-Montreal & 0.04 & 1.11 & NULL & 0.21 & 0.00 & 0.02 & 0.00 & NR & NR & 0.17 & 0.13 & 0.13 & 0.00 & 0.11 & NULL & 0.00 & 0.00 & 0.11 & 0.01 & 0.03 & 0.00 \\
\hline WI & 04020101 & $\begin{array}{l}\text { Black- } \\
\text { Presque Isle }\end{array}$ & 0.00 & 0.00 & NULL & 0.00 & 0.00 & 0.00 & 0.00 & NR & NR & 0.08 & 0.00 & 0.07 & 0.00 & 0.00 & NULL & 0.00 & 0.00 & 0.00 & 0.00 & 0.00 & 0.00 \\
\hline WI & 04020102 & Ontonagon & 0.00 & 0.00 & NULL & 0.00 & 0.00 & 0.00 & 0.00 & NR & NR & 0.05 & 0.00 & 0.04 & 0.00 & 0.00 & NULL & 0.00 & 0.00 & 0.00 & 0.00 & 0.00 & 0.00 \\
\hline WI & 04030101 & $\begin{array}{l}\text { Manitowoc- } \\
\text { Sheboygan }\end{array}$ & 2.21 & 18.14 & NULL & 0.89 & 0.00 & 0.81 & 0.00 & NR & NR & 1.26 & 0.82 & 0.68 & 0.00 & 0.46 & NULL & 2.54 & 0.40 & 5.16 & 0.57 & 0.48 & 0.00 \\
\hline WI & 04030102 & Door-Kewaunee & 0.64 & 6.11 & NULL & 0.20 & 0.00 & 0.19 & 0.00 & NR & NR & 1.68 & 0.09 & 1.34 & 0.00 & 0.07 & NULL & 0.50 & 0.00 & 1.50 & 0.17 & 0.22 & 0.00 \\
\hline WI & 04030103 & Duck-Pensaukee & 0.40 & 8.64 & NULL & 0.23 & 0.00 & 0.21 & 0.00 & NR & NR & 0.25 & 0.05 & 0.15 & 0.00 & 0.05 & NULL & 0.00 & 0.00 & 0.42 & 0.05 & 0.08 & 0.00 \\
\hline WI & 04030104 & Oconto & 0.23 & 2.04 & NULL & 0.15 & 0.00 & 0.14 & 0.00 & NR & NR & 1.41 & 0.08 & 1.30 & 0.00 & 0.07 & NULL & 0.05 & 0.60 & 0.73 & 0.08 & 0.08 & 0.00 \\
\hline WI & 04030105 & Peshtigo & 0.76 & 4.58 & NULL & 0.08 & 0.00 & 0.07 & 0.00 & NR & NR & 0.92 & 0.14 & 0.81 & 0.00 & 0.12 & NULL & 1.57 & 2.55 & 0.43 & 0.05 & 0.03 & 0.00 \\
\hline WI & 04030106 & Brule & 0.00 & 0.00 & NULL & 0.01 & 0.00 & 0.01 & 0.00 & NR & NR & 0.05 & 0.01 & 0.05 & 0.00 & 0.01 & NULL & 0.00 & 0.00 & 0.01 & 0.00 & 0.00 & 0.00 \\
\hline WI & 04030108 & Menominee & 0.72 & 4.16 & NULL & 0.08 & 0.00 & 0.07 & 0.00 & NR & NR & 0.93 & 0.11 & 0.84 & 0.00 & 0.10 & NULL & 0.00 & 0.00 & 0.33 & 0.04 & 0.02 & 0.00 \\
\hline WI & 04030201 & Upper Fox & 3.35 & 15.91 & NULL & 0.89 & 0.00 & 0.80 & 0.00 & NR & NR & 29.74 & 0.29 & 29.31 & 0.00 & 0.27 & NULL & 5.50 & 0.36 & 1.57 & 0.17 & 0.65 & 0.00 \\
\hline WI & 04030202 & Wolf & 6.87 & 48.48 & NULL & 0.94 & 0.00 & 0.68 & 0.00 & NR & NR & 67.52 & 1.44 & 66.73 & 0.00 & 1.31 & NULL & 3.67 & 14.29 & 3.26 & 0.36 & 0.60 & 0.00 \\
\hline WI & 04030203 & Lake Winnebago & 1.63 & 10.18 & NULL & 0.10 & 0.00 & 0.09 & 0.00 & NR & NR & 0.48 & 0.11 & 0.33 & 0.00 & 0.05 & NULL & 0.00 & 0.00 & 1.28 & 0.14 & 0.07 & 0.00 \\
\hline WI & 04030204 & Lower Fox & 2.85 & 60.74 & NULL & 0.31 & 0.00 & 0.27 & 0.00 & NR & NR & 0.55 & 0.30 & 0.09 & 0.00 & 0.23 & NULL & 0.00 & 0.04 & 1.98 & 0.22 & 0.36 & 0.00 \\
\hline WI & 04040002 & Pike-Root & 1.90 & 4.45 & NULL & 0.66 & 0.00 & 0.60 & 0.00 & NR & NR & 2.74 & 0.21 & 2.37 & 0.00 & 0.19 & NULL & 0.38 & 1.00 & 0.16 & 0.02 & 0.35 & 0.00 \\
\hline WI & 04040003 & Milwaukee & 3.10 & 4.69 & NULL & 0.83 & 0.00 & 0.35 & 0.00 & NR & NR & 1.45 & 0.25 & 0.76 & 0.00 & 0.14 & NULL & 0.00 & 0.00 & 1.53 & 0.17 & 0.82 & 0.00 \\
\hline WI & 04020300 & Lake Superior & 0.00 & 0.00 & NULL & 0.00 & 0.00 & 0.00 & 0.00 & NR & NR & 0.00 & 0.00 & 0.00 & 0.00 & 0.00 & NULL & 0.00 & 11.67 & 0.00 & 0.00 & 0.00 & 0.00 \\
\hline WI & 04060200 & Lake Michigan & 0.00 & 0.00 & NULL & 0.00 & 0.00 & 0.00 & 0.00 & NR & NR & 0.00 & 0.00 & 0.00 & 0.00 & 0.00 & NULL & 0.00 & 1.84 & 0.00 & 0.00 & 0.00 & 0.00 \\
\hline
\end{tabular}


Appendix 1C. Estimates of Withdrawals and Other Elements of Water Use by Watershed (8-digit HUC).

[The following is a listing of estimates of water use in 2005 derived from those compiled by each U.S. Geological Survey Water Science Center in the Great Lakes Basin and included in appendix $1 B$. These estimates support the summarized findings presented elsewhere in this report. The compiled values from selected New York watersheds (8-digit HUCs) within the Lake Erie and Lake Ontario watersheds are preliminary and have since been revised and approved as final; the following water-use estimates based in part or whole on the preliminary values are identified by bold typeface. This listing of estimates is available for download from the U.S.Geological Survey National Water-Use Information Web site (http://water.usgs.gov/watuse/). Column tags are defined in appendix $1 A$. Data Dictionary; NA, not applicable; NULL, value unknown, not reported]

\begin{tabular}{|c|c|c|c|c|c|c|c|c|c|c|c|c|c|c|c|c|}
\hline HUC8Code & HUC8Name & AREA & $\begin{array}{l}\text { INTEN- } \\
\text { A }\end{array}$ & $\begin{array}{l}\text { INTEN- } \\
\text { PC }\end{array}$ & $\begin{array}{c}\text { TP- } \\
\text { TotalPop }\end{array}$ & $\begin{array}{c}\text { PS- } \\
\text { Wtotal }\end{array}$ & $\begin{array}{c}\text { PS- } \\
\text { WGWFr }\end{array}$ & $\begin{array}{c}\text { PS- } \\
\text { WSWFr }\end{array}$ & $\begin{array}{l}\text { DO- } \\
\text { SSPop }\end{array}$ & $\begin{array}{c}\text { DO- } \\
\text { Wtotal }\end{array}$ & $\begin{array}{c}\text { DO- } \\
\text { WGWFr }\end{array}$ & $\begin{array}{c}\text { DO- } \\
\text { WSWFr }\end{array}$ & $\begin{array}{l}\text { DO- } \\
\text { PSDel }\end{array}$ & $\begin{array}{c}\text { PT- } \\
\text { Wtotal }\end{array}$ & $\begin{array}{c}\text { PT- } \\
\text { WGWFr }\end{array}$ & $\begin{array}{c}\text { PT- } \\
\text { WSWFr }\end{array}$ \\
\hline 04010101 & Baptism-Brule & 1,620 & 0.00 & 115 & 6.635 & 0.01 & 0.01 & 0.00 & 4.88 & 0.34 & 0.34 & 0.00 & 0.07 & 0.00 & 0.00 & 0.00 \\
\hline 04010102 & Beaver-Lester & 635 & 0.01 & 57 & 67.555 & 0.00 & 0.00 & 0.00 & 3.66 & 0.26 & 0.26 & 0.00 & 2.95 & 0.00 & 0.00 & 0.00 \\
\hline 04010201 & St. Louis & 3,010 & 0.09 & 1,809 & 146.457 & 11.22 & 5.99 & 5.23 & 28.63 & 1.65 & 1.65 & 0.00 & 6.76 & 190.34 & 0.11 & 190.23 \\
\hline 04010202 & Cloquet & 796 & 0.00 & 86 & 10.304 & 0.00 & 0.00 & 0.00 & 10.30 & 0.72 & 0.72 & 0.00 & 0.00 & 0.00 & 0.00 & 0.00 \\
\hline 04010301 & Beartrap-Nemadji & 1,850 & 0.00 & 171 & 43.266 & 0.37 & 0.37 & 0.00 & 17.10 & 0.88 & 0.88 & 0.00 & 1.81 & 0.00 & 0.00 & 0.00 \\
\hline 04010302 & Bad-Montreal & 1,330 & 0.00 & 207 & 20.358 & 1.23 & 1.23 & 0.00 & 7.54 & 0.28 & 0.28 & 0.00 & 0.71 & 0.00 & 0.00 & 0.00 \\
\hline 04020101 & Black-Presque Isle & 1,030 & 0.01 & 760 & 7.239 & 0.69 & 0.69 & 0.00 & 0.04 & 0.00 & 0.00 & 0.00 & 0.50 & 0.00 & 0.00 & 0.00 \\
\hline 04020102 & Ontonagon & 1,390 & 0.00 & 750 & 5.910 & 0.14 & 0.14 & 0.00 & 2.14 & 0.19 & 0.19 & 0.00 & 0.19 & 0.44 & 0.00 & 0.44 \\
\hline 04020103 & $\begin{array}{l}\text { Keweenaw Pen- } \\
\text { insula }\end{array}$ & 1,130 & 0.00 & 115 & 38.237 & 3.53 & 3.53 & 0.00 & 8.92 & 0.77 & 0.77 & 0.00 & 2.19 & 0.00 & 0.00 & 0.00 \\
\hline 04020104 & Sturgeon & 710 & 0.00 & 111 & 2.602 & 0.00 & 0.00 & 0.00 & 2.56 & 0.22 & 0.22 & 0.00 & 0.00 & 0.00 & 0.00 & 0.00 \\
\hline 04020105 & Dead-Kelsey & 946 & 0.02 & 323 & 47.498 & 1.42 & 1.42 & 0.00 & 2.49 & 0.22 & 0.22 & 0.00 & 3.13 & 0.00 & 0.00 & 0.00 \\
\hline 04020201 & Betsy-Chocolay & 1,180 & 0.01 & 341 & 19.706 & 0.56 & 0.56 & 0.00 & 15.21 & 1.31 & 1.31 & 0.00 & 0.40 & 0.00 & 0.00 & 0.00 \\
\hline 04020202 & Tahquamenon & 832 & 0.00 & 281 & 5.775 & 0.55 & 0.55 & 0.00 & 2.63 & 0.23 & 0.23 & 0.00 & 0.23 & 0.00 & 0.00 & 0.00 \\
\hline 04020300 & Lake Superior & 21,100 & NA & NA & 1.378 & 37.26 & 0.00 & 37.26 & 1.38 & 0.10 & 0.10 & 0.00 & 0.00 & 320.69 & 0.00 & 320.69 \\
\hline 04030101 & Manitowoc & 1,650 & 0.03 & 185 & 243.540 & 7.35 & 7.35 & 0.00 & 79.27 & 3.99 & 3.99 & 0.00 & 9.95 & 1.02 & 1.02 & 0.00 \\
\hline 04030102 & Door-Kewaunee & 776 & 0.02 & 265 & 56.888 & 2.59 & 2.59 & 0.00 & 37.78 & 1.37 & 1.37 & 0.00 & 1.06 & 0.01 & 0.01 & 0.00 \\
\hline 04030103 & Duck-Pensaukee & 483 & 0.02 & 705 & 15.890 & 0.51 & 0.51 & 0.00 & 10.06 & 0.45 & 0.45 & 0.00 & 0.17 & 0.00 & 0.00 & 0.00 \\
\hline 04030104 & Oconto & 1,040 & 0.01 & 256 & 31.386 & 1.50 & 1.50 & 0.00 & 20.35 & 1.03 & 1.03 & 0.00 & 0.50 & 0.00 & 0.00 & 0.00 \\
\hline 04030105 & Peshtigo & 1,170 & 0.01 & 401 & 35.373 & 0.86 & 0.86 & 0.00 & 17.25 & 0.85 & 0.85 & 0.00 & 0.97 & 1.31 & 0.00 & 1.31 \\
\hline 04030106 & Brule & 1,060 & 0.00 & 168 & 15.447 & 2.11 & 2.11 & 0.00 & 1.39 & 0.14 & 0.14 & 0.00 & 0.91 & 0.00 & 0.00 & 0.00 \\
\hline 04030107 & Michigamme & 734 & 0.01 & 3,033 & 2.189 & 0.15 & 0.15 & 0.00 & 1.49 & 0.13 & 0.13 & 0.00 & 0.10 & 0.00 & 0.00 & 0.00 \\
\hline 04030108 & Menominee & 2,310 & 0.03 & 1,055 & 56.686 & 3.39 & 3.39 & 0.00 & 32.04 & 2.22 & 2.22 & 0.00 & 2.01 & 24.87 & 0.00 & 24.87 \\
\hline 04030109 & Cedar-Ford & 1,010 & 0.00 & 145 & 19.069 & 0.06 & 0.06 & 0.00 & 8.77 & 0.76 & 0.76 & 0.00 & 0.57 & 0.00 & 0.00 & 0.00 \\
\hline 04030110 & Escanaba & 935 & 0.04 & 2,114 & 19.058 & 0.91 & 0.91 & 0.00 & 13.22 & 1.14 & 1.14 & 0.00 & 0.53 & 0.00 & 0.00 & 0.00 \\
\hline 04030111 & Tacoosh-Whitefish & 656 & 0.00 & 134 & 23.849 & 0.12 & 0.12 & 0.00 & 4.86 & 0.42 & 0.42 & 0.00 & 1.21 & 0.00 & 0.00 & 0.00 \\
\hline 04030112 & Fishdam-Sturgeon & 556 & 0.00 & 211 & 1.752 & 0.03 & 0.03 & 0.00 & 1.48 & 0.13 & 0.13 & 0.00 & 0.03 & 0.00 & 0.00 & 0.00 \\
\hline 04030201 & Upper Fox & 1,610 & 0.04 & 482 & 136.991 & 4.42 & 4.42 & 0.00 & 35.46 & 2.98 & 2.98 & 0.00 & 5.52 & 0.00 & 0.00 & 0.00 \\
\hline 04030204 & Lower Fox & 438 & 1.23 & 1,284 & 420.220 & 22.45 & 19.68 & 2.77 & 22.49 & 1.57 & 1.57 & 0.00 & 20.95 & 448.42 & 0.00 & 448.42 \\
\hline
\end{tabular}


Appendix 1C. Estimates of Withdrawals and Other Elements of Water Use by Watershed (Hydrologic Unit Code).-Continued

[The following is a listing of estimates of water use in 2005 derived from those compiled by each U.S. Geological Survey Water Science Center in the Great Lakes Basin and included in appendix $1 B$. These estimates support the summarized findings presented elsewhere in this report. The compiled values from selected New York watersheds (8-digit HUCs) within the Lake Erie and Lake Ontario watersheds are preliminary and have since been revised and approved as final; the following water-use estimates based in part or whole on the preliminary values are identified by bold typeface. This listing of estimates is available for download from the U.S.Geological Survey National Water-Use Information Web site (http://water.usgs.gov/watuse/). Column tags are

defined in appendix 1A. Data Dictionary; NA, not applicable; NULL, value unknown, not reported]

\begin{tabular}{|c|c|c|c|c|c|c|c|c|c|c|c|c|c|c|c|c|}
\hline HUC8Code & HUC8Name & $\begin{array}{c}\text { IN- } \\
\text { Wtotal }\end{array}$ & $\begin{array}{l}\text { IN- } \\
\text { WGWFr }\end{array}$ & $\begin{array}{l}\text { IN- } \\
\text { WSWFr }\end{array}$ & $\begin{array}{c}\text { MI- } \\
\text { Wtotal }\end{array}$ & $\begin{array}{c}\text { MI- } \\
\text { WGWto }\end{array}$ & $\begin{array}{c}\text { MI- } \\
\text { WSWFr }\end{array}$ & $\begin{array}{c}\text { IT- } \\
\text { Wtotal }\end{array}$ & $\begin{array}{c}\text { IT- } \\
\text { WGWFr }\end{array}$ & $\begin{array}{c}\text { IT- } \\
\text { WSWFr }\end{array}$ & $\begin{array}{c}\text { LA- } \\
\text { Wtotal }\end{array}$ & $\begin{array}{l}\text { LA- } \\
\text { WGWFr }\end{array}$ & $\begin{array}{l}\text { LA- } \\
\text { WSWFr }\end{array}$ & $\begin{array}{c}\text { LS- } \\
\text { Wtotal }\end{array}$ & $\begin{array}{l}\text { LS- } \\
\text { WGWFr }\end{array}$ & $\begin{array}{l}\text { LS- } \\
\text { WSWFr }\end{array}$ \\
\hline 04010101 & Baptism-Brule & 0.00 & 0.00 & 0.00 & 0.01 & 0.01 & 0.00 & 0.04 & 0.00 & 0.04 & 0.36 & 0.00 & 0.36 & 0.00 & 0.00 & 0.00 \\
\hline 04010102 & Beaver-Lester & 0.00 & 0.00 & 0.00 & 3.43 & 0.00 & 3.43 & 0.08 & 0.01 & 0.07 & 0.05 & 0.02 & 0.03 & 0.01 & 0.01 & 0.00 \\
\hline 04010201 & St. Louis & 6.20 & 0.01 & 6.19 & 54.81 & 0.02 & 54.79 & 0.28 & 0.02 & 0.26 & 0.29 & 0.27 & 0.02 & 0.15 & 0.15 & 0.00 \\
\hline 04010202 & Cloquet & 0.00 & 0.00 & 0.00 & 0.08 & 0.00 & 0.08 & 0.00 & 0.00 & 0.00 & 0.07 & 0.06 & 0.01 & 0.02 & 0.02 & 0.00 \\
\hline 04010301 & Beartrap-Nemadji & 0.98 & 0.02 & 0.96 & 0.61 & 0.54 & 0.07 & 0.34 & 0.30 & 0.04 & 3.93 & 3.92 & 0.01 & 0.27 & 0.25 & 0.02 \\
\hline 04010302 & Bad-Montreal & 1.23 & 0.12 & 1.11 & 0.23 & 0.21 & 0.02 & 0.30 & 0.17 & 0.13 & 0.83 & 0.00 & 0.83 & 0.12 & 0.11 & 0.01 \\
\hline 04020101 & Black-Presque Isle & 0.00 & 0.00 & 0.00 & 0.04 & 0.01 & 0.03 & 0.08 & 0.08 & 0.00 & 4.68 & 0.00 & 4.68 & 0.01 & 0.01 & 0.00 \\
\hline 04020102 & Ontonagon & 0.00 & 0.00 & 0.00 & 0.06 & 0.01 & 0.05 & 0.05 & 0.05 & 0.00 & 3.52 & 0.00 & 3.52 & 0.03 & 0.03 & 0.00 \\
\hline 04020103 & $\begin{array}{l}\text { Keweenaw Pen- } \\
\text { insula }\end{array}$ & 0.00 & 0.00 & 0.00 & 0.06 & 0.00 & 0.06 & 0.03 & 0.01 & 0.02 & 0.00 & 0.00 & 0.00 & 0.02 & 0.02 & 0.00 \\
\hline 04020104 & Sturgeon & 0.00 & 0.00 & 0.00 & 0.05 & 0.00 & 0.05 & 0.00 & 0.00 & 0.00 & 0.00 & 0.00 & 0.00 & 0.02 & 0.02 & 0.00 \\
\hline 04020105 & Dead-Kelsey & 0.00 & 0.00 & 0.00 & 13.59 & 2.71 & 10.88 & 0.10 & 0.05 & 0.05 & 0.00 & 0.00 & 0.00 & 0.02 & 0.02 & 0.00 \\
\hline 04020201 & Betsy-Chocolay & 0.35 & 0.35 & 0.00 & 4.26 & 0.84 & 3.42 & 0.02 & 0.01 & 0.01 & 0.19 & 0.14 & 0.05 & 0.03 & 0.03 & 0.00 \\
\hline 04020202 & Tahquamenon & 0.04 & 0.04 & 0.00 & 0.23 & 0.01 & 0.22 & 0.08 & 0.01 & 0.07 & 0.47 & 0.35 & 0.12 & 0.02 & 0.02 & 0.00 \\
\hline 04020300 & Lake Superior & 14.36 & 0.00 & 14.36 & 296.45 & 0.00 & 296.45 & 0.01 & 0.00 & 0.01 & 11.67 & 0.00 & 11.67 & 0.00 & 0.00 & 0.00 \\
\hline 04030101 & Manitowoc & 20.35 & 2.21 & 18.14 & 1.70 & 0.89 & 0.81 & 2.08 & 1.26 & 0.82 & 2.94 & 2.54 & 0.40 & 5.73 & 5.16 & 0.57 \\
\hline 04030102 & Door-Kewaunee & 6.75 & 0.64 & 6.11 & 0.39 & 0.20 & 0.19 & 1.77 & 1.68 & 0.09 & 0.50 & 0.50 & 0.00 & 1.67 & 1.50 & 0.17 \\
\hline 04030103 & Duck-Pensaukee & 9.04 & 0.40 & 8.64 & 0.44 & 0.23 & 0.21 & 0.30 & 0.25 & 0.05 & 0.00 & 0.00 & 0.00 & 0.47 & 0.42 & 0.05 \\
\hline 04030104 & Oconto & 2.27 & 0.23 & 2.04 & 0.29 & 0.15 & 0.14 & 1.49 & 1.41 & 0.08 & 0.65 & 0.05 & 0.60 & 0.81 & 0.73 & 0.08 \\
\hline 04030105 & Peshtigo & 5.34 & 0.76 & 4.58 & 0.15 & 0.08 & 0.07 & 1.06 & 0.92 & 0.14 & 4.12 & 1.57 & 2.55 & 0.48 & 0.43 & 0.05 \\
\hline 04030106 & Brule & 0.00 & 0.00 & 0.00 & 0.16 & 0.04 & 0.12 & 0.09 & 0.08 & 0.01 & 0.08 & 0.00 & 0.08 & 0.02 & 0.02 & 0.00 \\
\hline 04030107 & Michigamme & 0.00 & 0.00 & 0.00 & 5.73 & 1.14 & 4.59 & 0.62 & 0.10 & 0.52 & 0.00 & 0.00 & 0.00 & 0.01 & 0.01 & 0.00 \\
\hline 04030108 & Menominee & 27.07 & 1.15 & 25.92 & 0.29 & 0.09 & 0.20 & 1.39 & 1.05 & 0.34 & 0.00 & 0.00 & 0.00 & 0.56 & 0.50 & 0.06 \\
\hline 04030109 & Cedar-Ford & 0.03 & 0.03 & 0.00 & 1.66 & 0.31 & 1.35 & 0.04 & 0.02 & 0.02 & 0.00 & 0.00 & 0.00 & 0.21 & 0.19 & 0.02 \\
\hline 04030110 & Escanaba & 19.08 & 0.16 & 18.92 & 18.56 & 3.70 & 14.86 & 0.56 & 0.09 & 0.47 & 0.00 & 0.00 & 0.00 & 0.03 & 0.03 & 0.00 \\
\hline 04030111 & Tacoosh-Whitefish & 0.51 & 0.11 & 0.40 & 2.00 & 0.39 & 1.61 & 0.10 & 0.04 & 0.06 & 0.00 & 0.00 & 0.00 & 0.05 & 0.04 & 0.01 \\
\hline 04030112 & Fishdam-Sturgeon & 0.00 & 0.00 & 0.00 & 0.15 & 0.01 & 0.14 & 0.02 & 0.02 & 0.00 & 0.00 & 0.00 & 0.00 & 0.04 & 0.03 & 0.01 \\
\hline 04030201 & Upper Fox & 19.26 & 3.35 & 15.91 & 1.69 & 0.89 & 0.80 & 30.03 & 29.74 & 0.29 & 5.86 & 5.50 & 0.36 & 1.74 & 1.57 & 0.17 \\
\hline 04030202 & Wolf & 55.35 & 6.87 & 48.48 & 1.62 & 0.94 & 0.68 & 68.96 & 67.52 & 1.44 & 17.96 & 3.67 & 14.29 & 3.62 & 3.26 & 0.36 \\
\hline 04030203 & Lake Winnebago & 11.81 & 1.63 & 10.18 & 0.19 & 0.10 & 0.09 & 0.59 & 0.48 & 0.11 & 0.00 & 0.00 & 0.00 & 1.42 & 1.28 & 0.14 \\
\hline 04030204 & Lower Fox & 63.59 & 2.85 & 60.74 & 0.58 & 0.31 & 0.27 & 0.85 & 0.55 & 0.30 & 0.04 & 0.00 & 0.04 & 2.20 & 1.98 & 0.22 \\
\hline
\end{tabular}


[The following is a listing of estimates of water use in 2005 derived from those compiled by each U.S. Geological Survey Water Science Center in the Great Lakes Basin and included in appendix $1 B$. These estimates support the summarized findings presented elsewhere in this report. The compiled values from selected New York watersheds (8-digit HUCs) within the Lake Erie and Lake Ontario watersheds are preliminary and have since been revised and approved as final; the following water-use estimates based in part or whole on the preliminary values are identified by bold typeface. This listing of estimates is available for download from the U.S.Geological Survey National Water-Use Information Web site (http://water.usgs.gov/watuse). Column tags are defined in appendix $1 A$. Data Dictionary; NA, not applicable; NULL, value unknown, not reported]

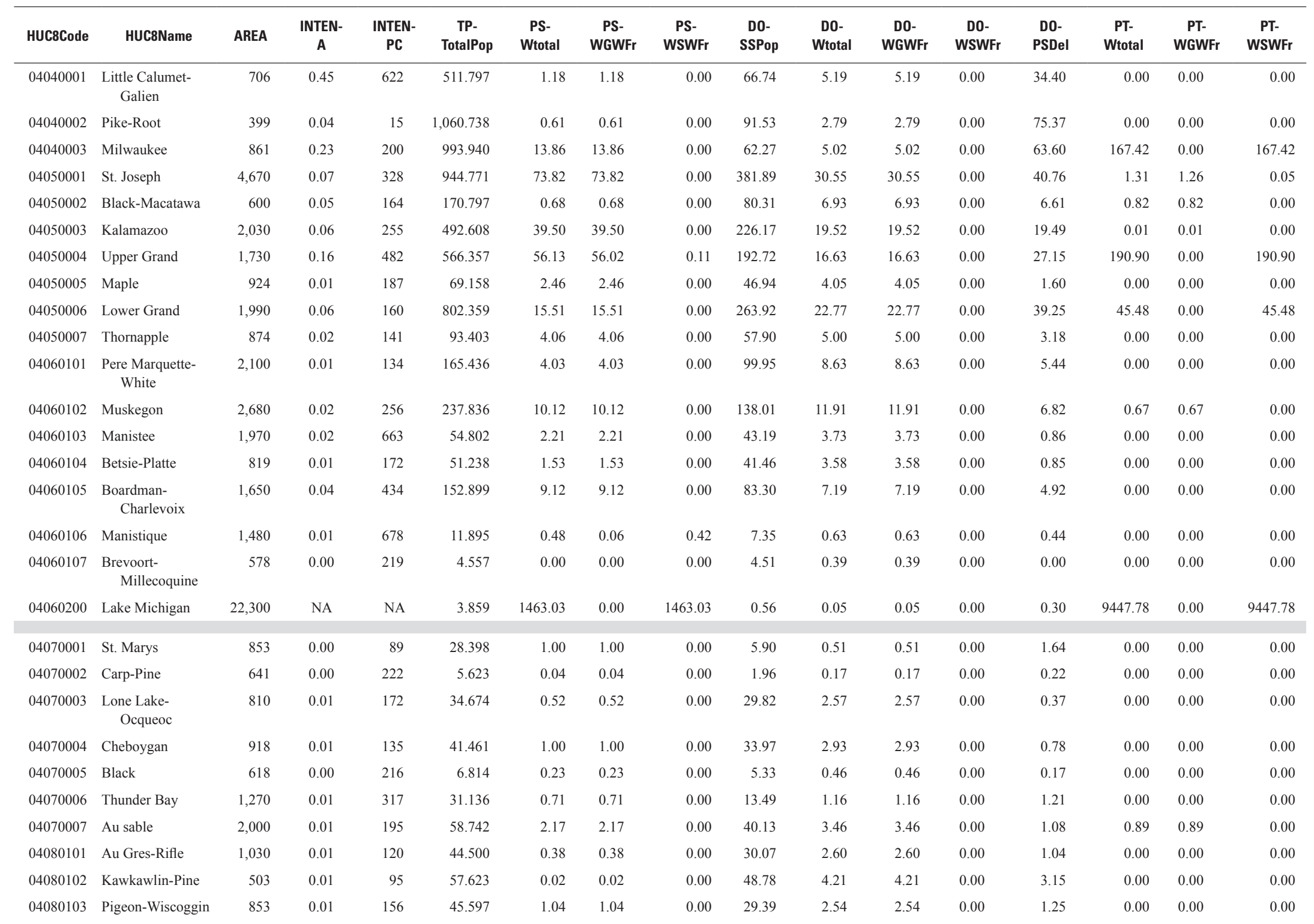


Appendix 1C. Estimates of Withdrawals and Other Elements of Water Use by Watershed (Hydrologic Unit Code).-Continued

[The following is a listing of estimates of water use in 2005 derived from those compiled by each U.S. Geological Survey Water Science Center in the Great Lakes Basin and included in appendix $1 B$. These estimates support the summarized findings presented elsewhere in this report. The compiled values from selected New York watersheds (8-digit HUCs) within the Lake Erie and Lake Ontario watersheds are preliminary and have since been revised and approved as final; the following water-use estimates based in part or whole on the preliminary values are identified by bold typeface. This listing of estimates is available for download from the U.S.Geological Survey National Water-Use Information Web site (http://water.usgs.gov/watuse). Column tags are defined in appendix $1 A$. Data Dictionary; NA, not applicable; NULL, value unknown, not reported]

\begin{tabular}{|c|c|c|c|c|c|c|c|c|c|c|c|c|c|c|c|c|}
\hline HUC8Code & HUC8Name & $\begin{array}{c}\text { IN- } \\
\text { Wtotal }\end{array}$ & $\begin{array}{l}\text { IN- } \\
\text { WGWFr }\end{array}$ & $\begin{array}{c}\text { IN- } \\
\text { WSWFr }\end{array}$ & $\begin{array}{c}\text { MI- } \\
\text { Wtotal }\end{array}$ & $\begin{array}{c}\text { MI- } \\
\text { WGWto }\end{array}$ & $\begin{array}{c}\text { MI- } \\
\text { WSWFr }\end{array}$ & $\begin{array}{c}\text { IT- } \\
\text { Wtotal }\end{array}$ & $\begin{array}{c}\text { IT- } \\
\text { WGWFr }\end{array}$ & $\begin{array}{c}\text { IT- } \\
\text { WSWFr }\end{array}$ & $\begin{array}{l}\text { LA- } \\
\text { Wtotal }\end{array}$ & $\begin{array}{l}\text { LA- } \\
\text { WGWFr }\end{array}$ & $\begin{array}{l}\text { LA- } \\
\text { WSWFr }\end{array}$ & $\begin{array}{c}\text { LS- } \\
\text { Wtotal }\end{array}$ & $\begin{array}{c}\text { LS- } \\
\text { WGWFr }\end{array}$ & $\begin{array}{c}\text { LS- } \\
\text { WSWFr }\end{array}$ \\
\hline 04040001 & $\begin{array}{l}\text { Little Calumet- } \\
\text { Galien }\end{array}$ & 310.38 & 1.95 & 308.43 & 0.15 & 0.00 & 0.15 & 1.06 & 0.45 & 0.61 & 0.00 & 0.00 & 0.00 & 0.23 & 0.13 & 0.10 \\
\hline 04040002 & Pike-Root & 6.35 & 1.90 & 4.45 & 1.26 & 0.66 & 0.60 & 3.41 & 3.18 & 0.23 & 1.38 & 0.38 & 1.00 & 0.18 & 0.16 & 0.02 \\
\hline 04040003 & Milwaukee & 7.79 & 3.10 & 4.69 & 1.18 & 0.83 & 0.35 & 1.70 & 1.45 & 0.25 & 0.00 & 0.00 & 0.00 & 1.70 & 1.53 & 0.17 \\
\hline 04050001 & St. Joseph & 17.42 & 15.42 & 2.00 & 5.76 & 0.38 & 5.38 & 175.34 & 122.62 & 52.72 & 0.05 & 0.05 & 0.00 & 5.58 & 3.85 & 1.73 \\
\hline 04050002 & Black-Macatawa & 6.83 & 0.17 & 6.66 & 1.11 & 0.01 & 1.10 & 10.78 & 6.76 & 4.02 & 0.03 & 0.03 & 0.00 & 0.81 & 0.73 & 0.08 \\
\hline 04050003 & Kalamazoo & 44.87 & 35.55 & 9.32 & 3.72 & 0.00 & 3.72 & 16.25 & 7.68 & 8.57 & 0.05 & 0.01 & 0.04 & 1.88 & 1.69 & 0.19 \\
\hline 04050004 & Upper Grand & 0.81 & 0.79 & 0.02 & 2.16 & 0.04 & 2.12 & 4.98 & 2.90 & 2.08 & 0.19 & 0.02 & 0.17 & 1.05 & 0.94 & 0.11 \\
\hline 04050005 & Maple & 0.82 & 0.82 & 0.00 & 0.88 & 0.00 & 0.88 & 3.66 & 2.40 & 1.26 & 0.00 & 0.00 & 0.00 & 1.03 & 0.92 & 0.11 \\
\hline 04050006 & Lower Grand & 3.50 & 1.78 & 1.72 & 2.03 & 0.00 & 2.03 & 37.02 & 28.85 & 8.17 & 0.38 & 0.02 & 0.36 & 2.02 & 1.82 & 0.20 \\
\hline 04050007 & Thornapple & 0.64 & 0.17 & 0.47 & 0.75 & 0.00 & 0.75 & 2.16 & 1.10 & 1.06 & 0.00 & 0.00 & 0.00 & 0.56 & 0.51 & 0.05 \\
\hline 04060101 & $\begin{array}{l}\text { Pere Marquette- } \\
\text { White }\end{array}$ & 1.86 & 1.86 & 0.00 & 0.30 & 0.00 & 0.30 & 5.30 & 3.47 & 1.83 & 1.18 & 0.07 & 1.11 & 0.80 & 0.73 & 0.07 \\
\hline 04060102 & Muskegon & 8.83 & 4.64 & 4.19 & 1.73 & 0.45 & 1.28 & 20.11 & 15.96 & 4.15 & 6.23 & 0.06 & 6.17 & 1.26 & 1.14 & 0.12 \\
\hline 04060103 & Manistee & 22.03 & 3.25 & 18.78 & 0.74 & 0.10 & 0.64 & 2.61 & 2.20 & 0.41 & 3.57 & 0.00 & 3.57 & 0.24 & 0.23 & 0.01 \\
\hline 04060104 & Betsie-Platte & 0.77 & 0.76 & 0.01 & 0.80 & 0.13 & 0.67 & 1.90 & 1.60 & 0.30 & 0.18 & 0.00 & 0.18 & 0.07 & 0.07 & 0.00 \\
\hline 04060105 & $\begin{array}{l}\text { Boardman- } \\
\quad \text { Charlevoix }\end{array}$ & 11.35 & 11.35 & 0.00 & 1.26 & 0.07 & 1.19 & 4.89 & 4.46 & 0.43 & 32.42 & 0.01 & 32.41 & 0.17 & 0.17 & 0.00 \\
\hline 04060106 & Manistique & 5.70 & 0.00 & 5.70 & 1.10 & 0.13 & 0.97 & 0.13 & 0.01 & 0.12 & 0.00 & 0.00 & 0.00 & 0.02 & 0.02 & 0.00 \\
\hline 04060107 & $\begin{array}{l}\text { Brevoort- } \\
\quad \text { Millecoquine }\end{array}$ & 0.00 & 0.00 & 0.00 & 0.51 & 0.01 & 0.50 & 0.08 & 0.08 & 0.00 & 0.00 & 0.00 & 0.00 & 0.02 & 0.02 & 0.00 \\
\hline 04060200 & Lake Michigan & 1426.59 & 0.32 & 1426.27 & 0.29 & 0.02 & 0.27 & 2.47 & 0.00 & 2.47 & 1.84 & 0.00 & 1.84 & 0.01 & 0.01 & 0.00 \\
\hline 04070001 & St. Marys & 0.05 & 0.05 & 0.00 & 0.27 & 0.01 & 0.26 & 0.08 & 0.04 & 0.04 & 0.60 & 0.44 & 0.16 & 0.02 & 0.02 & 0.00 \\
\hline 04070002 & Carp-Pine & 0.02 & 0.02 & 0.00 & 0.49 & 0.01 & 0.48 & 0.00 & 0.00 & 0.00 & 0.50 & 0.37 & 0.13 & 0.03 & 0.03 & 0.00 \\
\hline 04070003 & $\begin{array}{l}\text { Lone Lake- } \\
\text { Ocqueoc }\end{array}$ & 0.01 & 0.01 & 0.00 & 1.58 & 0.00 & 1.58 & 0.67 & 0.42 & 0.25 & 0.52 & 0.00 & 0.52 & 0.11 & 0.10 & 0.01 \\
\hline 04070004 & Cheboygan & 0.32 & 0.07 & 0.25 & 0.23 & 0.02 & 0.21 & 0.61 & 0.59 & 0.02 & 0.42 & 0.01 & 0.41 & 0.09 & 0.09 & 0.00 \\
\hline 04070005 & Black & 0.00 & 0.00 & 0.00 & 0.62 & 0.01 & 0.61 & 0.11 & 0.09 & 0.02 & 0.00 & 0.00 & 0.00 & 0.05 & 0.05 & 0.00 \\
\hline 04070006 & Thunder Bay & 4.04 & 0.00 & 4.04 & 1.10 & 0.01 & 1.09 & 1.22 & 0.72 & 0.50 & 1.46 & 0.01 & 1.45 & 0.18 & 0.17 & 0.01 \\
\hline 04070007 & Au Sable & 0.62 & 0.55 & 0.07 & 0.31 & 0.04 & 0.27 & 1.64 & 1.04 & 0.60 & 2.18 & 0.06 & 2.12 & 0.18 & 0.17 & 0.01 \\
\hline 04080101 & Au Gres-Rifle & 0.09 & 0.00 & 0.09 & 0.47 & 0.10 & 0.37 & 0.80 & 0.57 & 0.23 & 0.69 & 0.17 & 0.52 & 0.32 & 0.28 & 0.04 \\
\hline 04080102 & Kawkawlin-Pine & 0.19 & 0.19 & 0.00 & 0.02 & 0.00 & 0.02 & 0.91 & 0.16 & 0.75 & 0.00 & 0.00 & 0.00 & 0.11 & 0.11 & 0.00 \\
\hline 04080103 & Pigeon-Wiscoggin & 0.00 & 0.00 & 0.00 & 0.21 & 0.00 & 0.21 & 2.46 & 1.17 & 1.29 & 0.00 & 0.00 & 0.00 & 0.87 & 0.78 & 0.09 \\
\hline
\end{tabular}


[The following is a listing of estimates of water use in 2005 derived from those compiled by each U.S. Geological Survey Water Science Center in the Great Lakes Basin and included in appendix $1 B$. These estimates support the summarized findings presented elsewhere in this report. The compiled values from selected New York watersheds (8-digit HUCs) within the Lake Erie and Lake Ontario watersheds are preliminary and have since been revised and approved as final; the following water-use estimates based in part or whole on the preliminary values are identified by bold typeface. This listing of estimates is available for download from the U.S.Geological Survey National Water-Use Information Web site (http://water.usgs.gov/watuse/). Column tags are defined in appendix $1 A$. Data Dictionary; NA, not applicable; NULL, value unknown, not reported]

\begin{tabular}{|c|c|c|c|c|c|c|c|c|c|c|c|c|c|c|c|c|}
\hline HUC8Code & HUC8Name & AREA & $\begin{array}{c}\text { INTEN- } \\
\mathbf{A}\end{array}$ & $\begin{array}{l}\text { INTEN- } \\
\text { PC }\end{array}$ & $\begin{array}{c}\text { TP- } \\
\text { TotalPop }\end{array}$ & $\begin{array}{c}\text { PS- } \\
\text { Wtotal }\end{array}$ & $\begin{array}{c}\text { PS- } \\
\text { WGWFr }\end{array}$ & $\begin{array}{c}\text { PS- } \\
\text { WSWFr }\end{array}$ & $\begin{array}{c}\text { DO- } \\
\text { SSPop }\end{array}$ & $\begin{array}{c}\text { DO- } \\
\text { Wtotal }\end{array}$ & $\begin{array}{c}\text { DO- } \\
\text { WGWFr }\end{array}$ & $\begin{array}{c}\text { DO- } \\
\text { WSWFr }\end{array}$ & $\begin{array}{c}\text { DO- } \\
\text { PSDel }\end{array}$ & $\begin{array}{c}\text { PT- } \\
\text { Wtotal }\end{array}$ & $\begin{array}{c}\text { PT- } \\
\text { WGWFr }\end{array}$ & $\begin{array}{c}\text { PT- } \\
\text { WSWFr }\end{array}$ \\
\hline 04080104 & Birch-Willow & 572 & 0.00 & 80 & 31.946 & 0.30 & 0.30 & 0.00 & 12.24 & 1.06 & 1.06 & 0.00 & 1.45 & 0.00 & 0.00 & 0.00 \\
\hline 04080201 & Tittabawassee & 1,430 & 0.02 & 134 & 162.325 & 1.65 & 1.65 & 0.00 & 89.79 & 7.75 & 7.75 & 0.00 & 7.39 & 4.84 & 0.00 & 4.84 \\
\hline 04080202 & Pine & 1,040 & 0.02 & 175 & 111.236 & 5.33 & 4.65 & 0.68 & 60.58 & 5.23 & 5.23 & 0.00 & 4.04 & 0.12 & 0.12 & 0.00 \\
\hline 04080203 & Shiawassee & 1,220 & 0.02 & 148 & 198.153 & 10.99 & 10.99 & 0.00 & 119.29 & 10.29 & 10.29 & 0.00 & 7.53 & 0.00 & 0.00 & 0.00 \\
\hline 04080204 & Flint & 1,340 & 0.02 & 52 & 519.051 & 4.00 & 4.00 & 0.00 & 202.33 & 17.46 & 17.46 & 0.00 & 24.78 & 0.21 & 0.21 & 0.00 \\
\hline 04080205 & Cass & 881 & 0.01 & 113 & 70.655 & 2.80 & 2.80 & 0.00 & 35.89 & 3.10 & 3.10 & 0.00 & 2.45 & 0.00 & 0.00 & 0.00 \\
\hline 04080206 & Saginaw & 250 & 0.02 & 35 & 167.077 & 0.00 & 0.00 & 0.00 & 31.36 & 2.71 & 2.71 & 0.00 & 10.83 & 0.00 & 0.00 & 0.00 \\
\hline 04080300 & Lake Huron & 8,920 & $\mathrm{NA}$ & NA & 2.274 & 224.75 & 0.00 & 224.75 & 2.27 & 0.20 & 0.20 & 0.00 & 0.00 & 809.58 & 0.00 & 809.58 \\
\hline 04090001 & St. Clair & 1,210 & 0.01 & 69 & 175.839 & 2.11 & 2.11 & 0.00 & 76.04 & 6.56 & 6.56 & 0.00 & 8.00 & 0.00 & 0.00 & 0.00 \\
\hline 04090002 & Lake St. Clair & 413 & 0.01 & 6 & 619.321 & 0.01 & 0.01 & 0.00 & 33.82 & 2.91 & 2.91 & 0.00 & 49.64 & 0.00 & 0.00 & 0.00 \\
\hline 04090003 & Clinton & 742 & 0.05 & 38 & $1,069.471$ & 18.98 & 18.98 & 0.00 & 136.03 & 11.74 & 11.74 & 0.00 & 67.02 & 0.00 & 0.00 & 0.00 \\
\hline 04090004 & Detroit & 685 & 0.25 & 81 & $2,105.501$ & 0.86 & 0.86 & 0.00 & 0.60 & 0.05 & 0.05 & 0.00 & 170.62 & 162.10 & 0.00 & 162.10 \\
\hline 04090005 & Huron & 909 & 0.07 & 99 & 602.781 & 27.23 & 13.81 & 13.42 & 137.28 & 11.85 & 11.85 & 0.00 & 35.01 & 0.00 & 0.00 & 0.00 \\
\hline 04100002 & Raisin & 1,070 & 0.02 & 123 & 173.337 & 9.93 & 7.04 & 2.89 & 22.31 & 1.92 & 1.92 & 0.00 & 9.58 & 0.00 & 0.00 & 0.00 \\
\hline 04100003 & St. Joseph & 1,060 & 0.05 & 339 & 162.467 & 42.62 & 9.35 & 33.27 & 71.35 & 5.52 & 5.51 & 0.01 & 7.92 & 0.27 & 0.27 & 0.00 \\
\hline 04100004 & St. Marys & 820 & 0.02 & 98 & 194.954 & 5.27 & 5.27 & 0.00 & 25.60 & 1.93 & 1.91 & 0.02 & 12.84 & 5.64 & 0.00 & 5.64 \\
\hline 04100005 & Upper Maumee & 385 & 0.02 & 96 & 93.622 & 4.83 & 0.74 & 4.09 & 14.42 & 1.37 & 1.36 & 0.01 & 5.85 & 0.00 & 0.00 & 0.00 \\
\hline 04100006 & Tiffin & 781 & 0.01 & 149 & 61.232 & 4.98 & 2.95 & 2.03 & 30.33 & 2.40 & 2.37 & 0.03 & 1.96 & 0.00 & 0.00 & 0.00 \\
\hline 04100007 & Auglaize & 1,660 & 0.02 & 201 & 197.929 & 26.85 & 4.97 & 21.88 & 57.97 & 4.35 & 4.27 & 0.08 & 9.65 & 0.00 & 0.00 & 0.00 \\
\hline 04100008 & Blanchard & 757 & 0.06 & 512 & 92.257 & 8.95 & 1.19 & 7.76 & 37.85 & 2.84 & 2.78 & 0.06 & 4.57 & 0.00 & 0.00 & 0.00 \\
\hline 04100009 & Lower Maumee & 1,080 & 0.70 & 2531 & 298.637 & 10.73 & 1.02 & 9.71 & 57.80 & 4.34 & 4.25 & 0.09 & 20.41 & 730.69 & 0.00 & 730.69 \\
\hline 04100010 & Cedar-Portage & 958 & 0.07 & 388 & 169.879 & 6.45 & 1.08 & 5.37 & 52.62 & 3.95 & 3.87 & 0.08 & 5.11 & 0.00 & 0.00 & 0.00 \\
\hline 04100011 & Sandusky & 1,850 & 0.02 & 177 & 217.856 & 11.42 & 1.43 & 9.99 & 64.51 & 4.84 & 4.74 & 0.10 & 7.77 & 0.00 & 0.00 & 0.00 \\
\hline 04100012 & Huron-Vermilion & 754 & 0.01 & 90 & 92.201 & 4.26 & 0.39 & 3.87 & 4.10 & 0.31 & 0.30 & 0.01 & 5.57 & 0.00 & 0.00 & 0.00 \\
\hline 04110001 & Black-Rocky & 888 & 0.13 & 156 & 729.358 & 4.16 & 0.39 & 3.77 & 66.63 & 5.00 & 4.90 & 0.10 & 41.95 & 0.00 & 0.00 & 0.00 \\
\hline 04110002 & Cuyahoga & 804 & 0.23 & 180 & $1,040.667$ & 52.81 & 15.59 & 37.22 & 129.91 & 9.74 & 9.55 & 0.19 & 58.62 & 0.00 & 0.00 & 0.00 \\
\hline 04110003 & Ashtabula-Chagrin & 630 & 0.02 & 16 & 699.737 & 0.97 & 0.97 & 0.00 & 70.36 & 5.27 & 5.17 & 0.10 & 45.91 & 0.00 & 0.00 & 0.00 \\
\hline 04110004 & Grand & 710 & 0.01 & 34 & 120.473 & 0.29 & 0.24 & 0.05 & 32.17 & 2.41 & 2.36 & 0.05 & 7.16 & 0.00 & 0.00 & 0.00 \\
\hline 04120102 & Cattaraugus & 548 & 0.01 & 176 & 43.613 & 3.07 & 2.35 & 0.72 & 10.20 & 0.92 & 0.92 & 0.00 & 3.47 & 0.00 & 0.00 & 0.00 \\
\hline
\end{tabular}


Appendix 1C. Estimates of Withdrawals and Other Elements of Water Use by Watershed (Hydrologic Unit Code).-Continued

[The following is a listing of estimates of water use in 2005 derived from those compiled by each U.S. Geological Survey Water Science Center in the Great Lakes Basin and included in appendix $1 B$. These estimates support the summarized findings presented elsewhere in this report. The compiled values from selected New York watersheds (8-digit HUCs) within the Lake Erie and Lake Ontario watersheds are preliminary and have since been revised and approved as final; the following water-use estimates based in part or whole on the preliminary values are identified by bold typeface. This listing of estimates is available for download from the U.S.Geological Survey National Water-Use Information Web site (http://water.usgs.gov/watuse). Column tags are defined in appendix $1 A$. Data Dictionary; NA, not applicable; NULL, value unknown, not reported]

\begin{tabular}{|c|c|c|c|c|c|c|c|c|c|c|c|c|c|c|c|c|}
\hline HUC8Code & HUC8Name & $\begin{array}{c}\text { IN- } \\
\text { Wtotal }\end{array}$ & $\begin{array}{c}\text { IN- } \\
\text { WGWFr }\end{array}$ & $\begin{array}{c}\text { IN- } \\
\text { WSWFr }\end{array}$ & $\begin{array}{c}\text { MI- } \\
\text { Wtotal }\end{array}$ & $\begin{array}{c}\text { MI- } \\
\text { WGWto }\end{array}$ & $\begin{array}{c}\text { MI- } \\
\text { WSWFr }\end{array}$ & $\begin{array}{c}\text { IT- } \\
\text { Wtotal }\end{array}$ & $\begin{array}{c}\text { IT- } \\
\text { WGWFr }\end{array}$ & $\begin{array}{c}\text { IT- } \\
\text { WSWFr }\end{array}$ & $\begin{array}{c}\text { LA- } \\
\text { Wtotal }\end{array}$ & $\begin{array}{c}\text { LA- } \\
\text { WGWFr }\end{array}$ & $\begin{array}{c}\text { LA- } \\
\text { WSWFr }\end{array}$ & $\begin{array}{c}\text { LS- } \\
\text { Wtotal }\end{array}$ & $\begin{array}{c}\text { LS- } \\
\text { WGWFr }\end{array}$ & $\begin{array}{c}\text { LS- } \\
\text { WSWFr }\end{array}$ \\
\hline 04080104 & Birch-Willow & 0.04 & 0.04 & 0.00 & 0.25 & 0.00 & 0.25 & 0.24 & 0.18 & 0.06 & 0.02 & 0.02 & 0.00 & 0.66 & 0.59 & 0.07 \\
\hline 04080201 & Tittabawassee & 6.14 & 0.14 & 6.00 & 0.37 & 0.00 & 0.37 & 0.47 & 0.21 & 0.26 & 0.08 & 0.03 & 0.05 & 0.39 & 0.35 & 0.04 \\
\hline 04080202 & Pine & 0.57 & 0.57 & 0.00 & 0.41 & 0.03 & 0.38 & 5.37 & 3.53 & 1.84 & 1.80 & 0.00 & 1.80 & 0.68 & 0.61 & 0.07 \\
\hline 04080203 & Shiawassee & 0.21 & 0.21 & 0.00 & 2.32 & 0.11 & 2.21 & 5.10 & 2.63 & 2.47 & 0.00 & 0.00 & 0.00 & 0.40 & 0.37 & 0.03 \\
\hline 04080204 & Flint & 0.13 & 0.13 & 0.00 & 1.76 & 0.16 & 1.60 & 2.95 & 1.43 & 1.52 & 0.00 & 0.00 & 0.00 & 0.40 & 0.36 & 0.04 \\
\hline 04080205 & Cass & 0.08 & 0.00 & 0.08 & 0.37 & 0.00 & 0.37 & 1.02 & 0.82 & 0.20 & 0.03 & 0.03 & 0.00 & 0.57 & 0.51 & 0.06 \\
\hline 04080206 & Saginaw & 2.65 & 0.00 & 2.65 & 0.01 & 0.00 & 0.01 & 0.40 & 0.27 & 0.13 & 0.00 & 0.00 & 0.00 & 0.06 & 0.06 & 0.00 \\
\hline 04080300 & Lake Huron & 19.55 & 0.00 & 19.55 & 0.17 & 0.01 & 0.16 & 3.06 & 0.00 & 3.06 & 0.34 & 0.25 & 0.09 & 0.01 & 0.01 & 0.00 \\
\hline 04090001 & St. Clair & 0.08 & 0.08 & 0.00 & 0.82 & 0.00 & 0.82 & 1.89 & 0.78 & 1.11 & 0.04 & 0.04 & 0.00 & 0.65 & 0.58 & 0.07 \\
\hline 04090002 & Lake St. Clair & 0.00 & 0.00 & 0.00 & 0.25 & 0.01 & 0.24 & 0.48 & 0.28 & 0.20 & 0.01 & 0.01 & 0.00 & 0.03 & 0.03 & 0.00 \\
\hline 04090003 & Clinton & 0.66 & 0.66 & 0.00 & 3.32 & 0.55 & 2.77 & 5.35 & 1.83 & 3.52 & 0.02 & 0.02 & 0.00 & 0.08 & 0.07 & 0.01 \\
\hline 04090004 & Detroit & 1.66 & 0.20 & 1.46 & 2.52 & 0.34 & 2.18 & 2.46 & 1.10 & 1.36 & 0.10 & 0.02 & 0.08 & 0.04 & 0.04 & 0.00 \\
\hline 04090005 & Huron & 11.78 & 2.98 & 8.80 & 3.60 & 0.35 & 3.25 & 3.89 & 2.43 & 1.46 & 1.12 & 0.18 & 0.94 & 0.23 & 0.20 & 0.03 \\
\hline 04100002 & Raisin & 2.44 & 1.07 & 1.37 & 2.44 & 0.69 & 1.75 & 3.49 & 1.15 & 2.34 & 0.62 & 0.10 & 0.52 & 0.55 & 0.47 & 0.08 \\
\hline 04100003 & St. Joseph & 4.28 & 4.00 & 0.28 & 0.70 & 0.00 & 0.70 & 0.68 & 0.46 & 0.22 & 0.00 & 0.00 & 0.00 & 0.93 & 0.56 & 0.37 \\
\hline 04100004 & St. Marys & 1.54 & 0.10 & 1.44 & 2.01 & 1.63 & 0.38 & 0.20 & 0.15 & 0.05 & 0.61 & 0.38 & 0.23 & 1.91 & 1.12 & 0.79 \\
\hline 04100005 & Upper Maumee & 1.79 & 0.63 & 1.16 & 0.73 & 0.00 & 0.73 & 0.04 & 0.02 & 0.02 & 0.00 & 0.00 & 0.00 & 0.24 & 0.10 & 0.14 \\
\hline 04100006 & Tiffin & 0.10 & 0.10 & 0.00 & 0.28 & 0.04 & 0.24 & 0.90 & 0.35 & 0.55 & 0.00 & 0.00 & 0.00 & 0.49 & 0.21 & 0.28 \\
\hline 04100007 & Auglaize & 1.34 & 1.14 & 0.20 & 5.72 & 5.45 & 0.27 & 0.53 & 0.28 & 0.25 & 0.00 & 0.00 & 0.00 & 1.00 & 0.29 & 0.71 \\
\hline 04100008 & Blanchard & 31.92 & 5.30 & 26.62 & 2.68 & 2.62 & 0.06 & 0.47 & 0.13 & 0.34 & 0.00 & 0.00 & 0.00 & 0.37 & 0.06 & 0.31 \\
\hline 04100009 & Lower Maumee & 6.71 & 0.01 & 6.70 & 2.19 & 2.19 & 0.00 & 0.97 & 0.55 & 0.42 & 0.00 & 0.00 & 0.00 & 0.36 & 0.07 & 0.29 \\
\hline 04100010 & Cedar-Portage & 53.33 & 5.82 & 47.51 & 1.43 & 1.43 & 0.00 & 0.65 & 0.49 & 0.16 & 0.00 & 0.00 & 0.00 & 0.17 & 0.04 & 0.13 \\
\hline 04100011 & Sandusky & 9.38 & 0.43 & 8.95 & 8.17 & 7.99 & 0.18 & 0.42 & 0.20 & 0.22 & 3.43 & 0.00 & 3.43 & 0.84 & 0.14 & 0.70 \\
\hline 04100012 & Huron-Vermilion & 0.08 & 0.08 & 0.00 & 0.00 & 0.00 & 0.00 & 3.29 & 0.39 & 2.90 & 0.00 & 0.00 & 0.00 & 0.34 & 0.10 & 0.24 \\
\hline 04110001 & Black-Rocky & 101.03 & 0.08 & 100.95 & 0.00 & 0.00 & 0.00 & 3.26 & 0.12 & 3.14 & 0.00 & 0.00 & 0.00 & 0.41 & 0.15 & 0.26 \\
\hline 04110002 & Cuyahoga & 122.08 & 1.70 & 120.38 & 0.74 & 0.20 & 0.54 & 1.57 & 0.72 & 0.85 & 0.00 & 0.00 & 0.00 & 0.17 & 0.08 & 0.09 \\
\hline 04110003 & Ashtabula-Chagrin & 0.00 & 0.00 & 0.00 & 0.01 & 0.00 & 0.01 & 4.71 & 0.30 & 4.41 & 0.06 & 0.03 & 0.03 & 0.19 & 0.09 & 0.10 \\
\hline 04110004 & Grand & 0.40 & 0.00 & 0.40 & 0.00 & 0.00 & 0.00 & 0.64 & 0.10 & 0.54 & 0.00 & 0.00 & 0.00 & 0.32 & 0.13 & 0.19 \\
\hline 04120102 & Cattaraugus & 1.09 & 0.50 & 0.59 & 0.58 & 0.15 & 0.43 & 0.58 & 0.16 & 0.42 & 0.96 & 0.48 & 0.48 & 0.48 & 0.31 & 0.17 \\
\hline
\end{tabular}


[The following is a listing of estimates of water use in 2005 derived from those compiled by each U.S. Geological Survey Water Science Center in the Great Lakes Basin and included in appendix $1 B$. These estimates support the summarized findings presented elsewhere in this report. The compiled values from selected New York watersheds (8-digit HUCs) within the Lake Erie and Lake Ontario watersheds are preliminary and have since been revised and approved as final; the following water-use estimates based in part or whole on the preliminary values are identified by bold typeface. This listing of estimates is available for download from the U.S.Geological Survey National Water-Use Information Web site (http://water.usgs.gov/watuse). Column tags are defined in appendix 1A. Data Dictionary; NA, not applicable; NULL, value unknown, not reported]

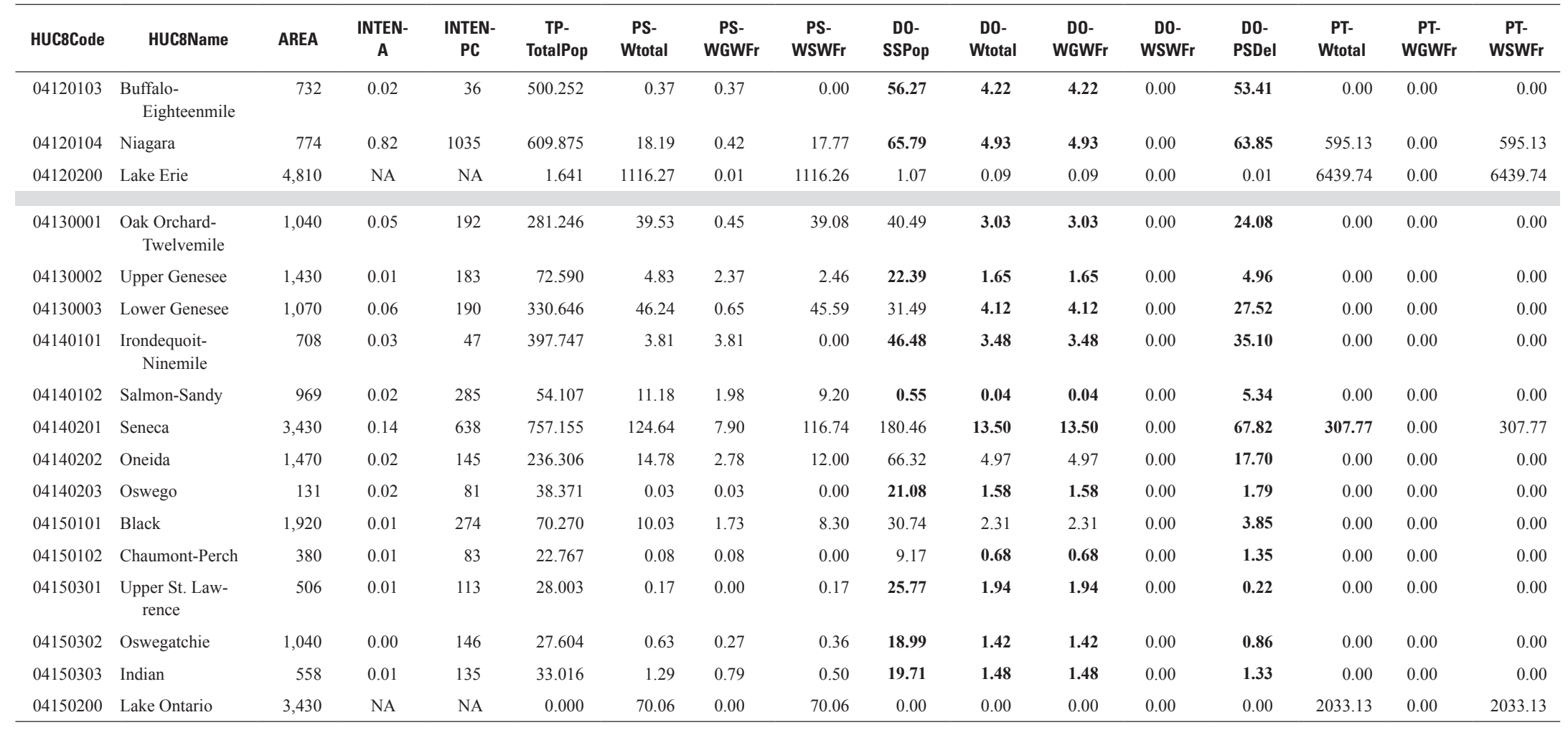


Appendix 1C. Estimates of Withdrawals and Other Elements of Water Use by Watershed (Hydrologic Unit Code).-Continued

[The following is a listing of estimates of water use in 2005 derived from those compiled by each U.S. Geological Survey Water Science Center in the Great Lakes Basin and included in appendix $1 B$. These estimates support the summarized findings presented elsewhere in this report. The compiled values from selected New York watersheds (8-digit HUCs) within the Lake Erie and Lake Ontario watersheds are preliminary and have since been revised and approved as final; the following water-use estimates based in part or whole on the preliminary values are identified by bold typeface. This listing of estimates is available for download from the U.S.Geological Survey National Water-Use Information Web site (http://water.usgs.gov/watuse/). Column tags are defined in appendix $1 A$. Data Dictionary; NA, not applicable; NULL, value unknown, not reported]

\begin{tabular}{|c|c|c|c|c|c|c|c|c|c|c|c|c|c|c|c|c|}
\hline HUC8Code & HUC8Name & $\begin{array}{c}\text { IN- } \\
\text { Wtotal }\end{array}$ & $\begin{array}{c}\text { IN- } \\
\text { WGWFr }\end{array}$ & $\begin{array}{c}\text { IN- } \\
\text { WSWFr }\end{array}$ & $\begin{array}{c}\text { MI- } \\
\text { Wtotal }\end{array}$ & $\begin{array}{c}\text { MI- } \\
\text { WGWto }\end{array}$ & $\begin{array}{c}\text { MI- } \\
\text { WSWFr }\end{array}$ & $\begin{array}{c}\text { IT- } \\
\text { Wtotal }\end{array}$ & $\begin{array}{c}\text { IT- } \\
\text { WGWFr }\end{array}$ & $\begin{array}{c}\text { IT- } \\
\text { WSWFr }\end{array}$ & $\begin{array}{c}\text { LA- } \\
\text { Wtotal }\end{array}$ & $\begin{array}{l}\text { LA- } \\
\text { WGWFr }\end{array}$ & $\begin{array}{l}\text { LA- } \\
\text { WSWFr }\end{array}$ & $\begin{array}{c}\text { LS- } \\
\text { Wtotal }\end{array}$ & $\begin{array}{c}\text { LS- } \\
\text { WGWFr }\end{array}$ & $\begin{array}{c}\text { LS- } \\
\text { WSWFr }\end{array}$ \\
\hline 04120103 & $\begin{array}{l}\text { Buffalo- } \\
\text { Eighteenmile }\end{array}$ & 10.20 & 0.14 & 10.06 & 0.76 & 0.16 & 0.60 & 1.69 & 0.46 & 1.23 & 0.02 & 0.01 & 0.01 & 0.77 & 0.50 & 0.27 \\
\hline 04120104 & Niagara & 8.61 & 0.45 & 8.16 & 0.73 & 0.16 & 0.57 & 2.29 & 0.82 & 1.47 & 0.02 & 0.01 & 0.01 & 1.09 & 0.71 & 0.38 \\
\hline 04120200 & Lake Erie & 302.73 & 0.00 & 302.73 & 11.65 & 7.24 & 4.41 & 0.64 & 0.01 & 0.63 & 0.00 & 0.00 & 0.00 & 0.00 & 0.00 & 0.00 \\
\hline 04130001 & $\begin{array}{l}\text { Oak Orchard- } \\
\text { Twelvemile }\end{array}$ & 6.44 & 0.27 & 6.17 & 0.89 & 0.20 & 0.69 & 3.44 & 1.30 & 2.14 & 0.00 & 0.00 & 0.00 & 0.62 & 0.40 & 0.22 \\
\hline 04130002 & Upper Genesee & 1.47 & 0.86 & 0.61 & 0.84 & 0.19 & 0.65 & 1.12 & 0.31 & 0.81 & 1.81 & 0.24 & 1.57 & 1.57 & 1.03 & 0.54 \\
\hline 04130003 & Lower Genesee & 7.34 & 0.83 & 6.51 & 0.95 & 0.19 & 0.76 & 2.68 & 0.72 & 1.96 & 0.08 & 0.01 & 0.07 & 1.49 & 0.97 & 0.52 \\
\hline 04140101 & $\begin{array}{l}\text { Irondequoit- } \\
\text { Ninemile }\end{array}$ & 9.05 & 0.77 & 8.28 & 0.40 & 0.09 & 0.31 & 1.21 & 0.32 & 0.89 & 0.34 & 0.07 & 0.27 & 0.43 & 0.28 & 0.15 \\
\hline 04140102 & Salmon-Sandy & 1.07 & 0.37 & 0.70 & 0.34 & 0.07 & 0.27 & 0.53 & 0.15 & 0.38 & 1.66 & 0.00 & 1.66 & 0.60 & 0.39 & 0.21 \\
\hline 04140201 & Seneca & 25.67 & 2.88 & 22.79 & 3.64 & 0.73 & 2.91 & 3.47 & 0.99 & 2.48 & 1.03 & 0.29 & 0.74 & 3.68 & 2.38 & 1.30 \\
\hline 04140202 & Oneida & 7.15 & 1.15 & 6.00 & 0.67 & 0.15 & 0.52 & 1.59 & 0.45 & 1.14 & 3.85 & 1.24 & 2.61 & 1.25 & 0.81 & 0.44 \\
\hline 04140203 & Oswego & 0.90 & 0.26 & 0.64 & 0.07 & 0.01 & 0.06 & 0.15 & 0.04 & 0.11 & 0.30 & 0.00 & 0.30 & 0.06 & 0.04 & 0.02 \\
\hline 04150101 & Black & 1.61 & 0.50 & 1.11 & 0.41 & 0.09 & 0.32 & 0.48 & 0.13 & 0.35 & 3.18 & 1.24 & 1.94 & 1.22 & 0.79 & 0.43 \\
\hline 04150102 & Chaumont-Perch & 0.44 & 0.09 & 0.35 & 0.15 & 0.03 & 0.12 & 0.16 & 0.05 & 0.11 & 0.00 & 0.00 & 0.00 & 0.39 & 0.25 & 0.14 \\
\hline 04150301 & $\begin{array}{l}\text { Upper St. Law- } \\
\text { rence }\end{array}$ & 0.55 & 0.12 & 0.43 & 0.09 & 0.02 & 0.07 & 0.11 & 0.04 & 0.07 & 0.02 & 0.00 & 0.02 & 0.28 & 0.18 & 0.10 \\
\hline 04150302 & Oswegatchie & 0.55 & 0.13 & 0.42 & 0.21 & 0.04 & 0.17 & 0.19 & 0.08 & 0.11 & 0.40 & 0.13 & 0.27 & 0.63 & 0.41 & 0.22 \\
\hline 04150303 & Indian & 0.64 & 0.14 & 0.50 & 0.16 & 0.03 & 0.13 & 0.18 & 0.06 & 0.12 & 0.23 & 0.00 & 0.23 & 0.49 & 0.32 & 0.17 \\
\hline 04150200 & Lake Ontario & 0.22 & 0.00 & 0.22 & 0.00 & 0.00 & 0.00 & 0.04 & 0.01 & 0.03 & 0.00 & 0.00 & 0.00 & 0.00 & 0.00 & 0.00 \\
\hline
\end{tabular}






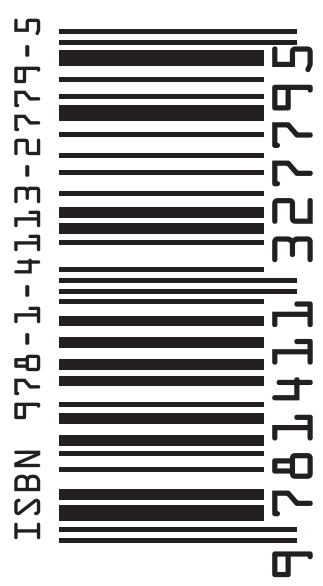

